Hosszú Zsuzsanna

\title{
A magyar bankrendszer makroprudenciális szempontból
}


Matematikai Közgazdaságtan és Gazdaságelemzés Tanszék

Témavezető:

Vincze János, DSc

egyetemi tanár

(C) Hosszú Zsuzsanna 


\title{
Budapesti Corvinus Egyetem
}

\author{
Általános és Kvantitatív Közgazdaságtan \\ Doktori Iskola
}

\section{A magyar bankrendszer makroprudenciális szempontból \\ doktori értekezés}

Hosszú Zsuzsanna

Budapest, 2018 



\section{Tartalomjegyzék}

1. Bevezetés és történeti áttekintés 13

1.1. Bevezetés . . . . . . . . . . . . . . . . . . 13

1.2. Az elmúlt évek áttekintése . . . . . . . . . . . . . . . . . . . 16

1.2.1. Háztartási hitelezés, és az ehhez kapcsolódó kormányzati intézkedések . . . . . . . . . . . . . 16

1.2.2. A vállalati hitelezés alakulása az elmúlt 15 évben . . . . . . 19

2. Hitelkínálati sokkok hatása és egy új pénzügyi kondíciós index egy

FAVAR modell alapján 23

2.1. A kapcsolódó irodalom áttekintése . . . . . . . . . . . . . . 23

2.2. Adatok és módszertan . . . . . . . . . . . . . . 27

2.2.1. Pénzügyi és makrogazdasági adatok . . . . . . . . . . . . 27

2.2.2. Időben változó paraméterû FAVAR . . . . . . . . . . . 29

2.2.3. A modell becslése . . . . . . . . . . . . . . 32

2.3. Eredmények . . . . . . . . . . . . . . . . 35

2.3.1. Faktorok . . . . . . . . . . . . . . . 35

2.3.2. Pénzügyi faktorok . . . . . . . . . . . . . . . 40

2.3.3. Hitelezési hajlandóság . . . . . . . . . . . . . 42

2.3.4. Hitelezési képesség . . . . . . . . . . . . . . . 43 
2.3.5. Pénzügyi kondíciós index . . . . . . . . . . . . . . 47

2.4. A fejezet összegzése . . . . . . . . . . . . . . . . . 50

3. A nemteljesítési valószínûség és az optimális jövedelemarányos törlesztốrészlet-szabály modellezése egy háztartási kérdôíves felmérés felhasználásával

3.1. Bevezetố . . . . . . . . . . . . . . . . . 53

3.2. Adatok . . . . . . . . . . . . . . . . . . 59

3.3. A nemteljesítési valószínűség modellezése . . . . . . . . . . . 63

3.3.1. A modell struktúrája . . . . . . . . . . . . . . 63

3.3.2. Parciális hatások ................. 67

3.3.3. Robusztusságvizsgálat . . . . . . . . . . . 70

3.4. Kimaradt változók . . . . . . . . . . . . . . . . . 72

3.4.1. Lakáshitel vs. szabadfelhasználású hitel . . . . . . . . . . . 72

3.4.2. Vintage hatás . . . . . . . . . . . . 74

3.4.3. Egyéb kimaradt változók . . . . . . . . . . . . . 78

3.5. A jövedelemarányos törlesztőrészlet és a hitelkockázat kapcsolata. . 81

3.6. A fejezet összegzése . . . . . . . . . . . . . . . . . 87

4. Banki hatékonyság és piaci erố mérése a háztartási és a vállalati $\begin{array}{lr}\text { hitelpiacon } & 89\end{array}$

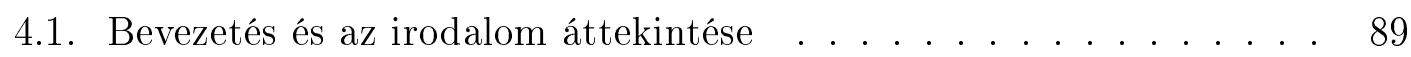

4.2. Adatok és módszertan . . . . . . . . . . . . . . . . . 94

4.2.1. Az SFA modellek . . . . . . . . . . . . . . . . . 97

4.2.2. A DEA modellek . . . . . . . . . . . . . . . . . 99

4.2.3. Adatok . . . . . . . . . . . . . . . 103

4.3. Eredmények . . . . . . . . . . . . . . . . . . . 104 
4.3.1. Az SFA és a DEA modellek eredményeinek összehasonlítása 105

4.3.2. A válság hatása a hatékonyságra . . . . . . . . . . . . 112

4.3.3. A háztartási és a vállalati Lerner-indexek . . . . . . . . . . . 115

4.4. A fejezet összegzése . . . . . . . . . . . . . . . . . 122

$\begin{array}{ll}\text { 5. Összegzés } & 125\end{array}$

\begin{tabular}{lr}
\hline Hivatkozások & 131
\end{tabular}

A Függelék: a faktormodellel kapcsolatos kiegészítô információk 143

B Függelék: a nemteljesítési valószínûség és az optimális jövedelemarányos törlesztôrészlet-szabály modellezésével kapcsolatos kiegészítô információk

C Függelék: a banki hatékonyság és verseny mérésével kapcsolatos kiegészítô információk

Saját publikációk a témában 189 


\section{Táblázatok jegyzéke}

2.1. Decay és forgetting faktorok . . . . . . . . . . . . . . 35

2.2. A pénzügyi faktorokra és az eredeti változókra futtatott regressziók

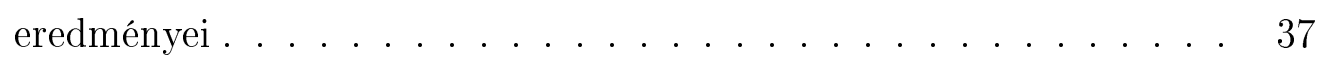

3.1. A különböző hiteltermékek állományarányos eloszlása a mintában és a bankrendszerben ..................... 61

3.2. A különbözô hiteltermékek állományi devizális eloszlása a mintában és a bankrendszerben . . . . . . . . . . . . . . . . . . 62

3.3. A különbözô jelzáloghitelek késettség szerinti állományi eloszlása a mintában és a bankrendszerben . . . . . . . . . . . 63

3.4. A becsült modell változóinak átlagos parciális hatásai és szignifikan-

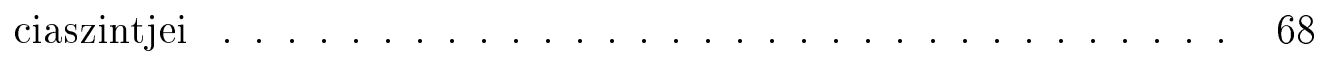

3.5. A szabadfelhasználású jelzáloghitelek és a lakáshitelek néhány tulajdonsága I. . . . . . . . . . . . . 74

3.6. A szabadfelhasználású jelzáloghitelek és a lakáshitelek néhány tulajdonsága II. . . . . . . . . . . . . . . 75

3.7. A két vizsgált idôszakban kibocsátott hitelek néhány tulajdonsága I. 77

3.8. A két vizsgált időszakban kibocsátott hitelek néhány tulajdonsága II. 78

3.9. Egy átlagos háztartás 10\%-os hosszú távú PD-hez tartozó PTI-je különbözô jövedelmek és denomináció mellett (teljes minta)] . . . . 85 
3.10. Egy átlagos háztartás 10\%-os hosszú távú PD-hez tartozó PTI-je különböző jövedelmek és denomináció mellett (2004-2008)] . . . . . . 86

4.1. A hatékonytalanságok leíró statisztikái (teljes minta) . . . . . . . 105

4.2. A hatékonytalanságok korrelációja és Spearman-féle korrelációja . . 107

4.3. A legjobb és legrosszabb bankok besorolása . . . . . . . . . . . . . 109

4.4. Autokorrelációk . . . . . . . . . . . . . . . . . . . 110

4.5. A hatékonytalansági mutatók elsôrendú autokorrelációja bankonként 111

4.6. A becsült hatékonytalanságok összehasonlítása a pénzügyi jövedelmezôségi és hatékonysági mutatókkal . . . . . . . . . . . . . 112

5.1. Makrogazdasági idôsorok . . . . . . . . . . . . . . . . 143

5.2. A makrogazdasági változókra és faktorokra futtatott regressziók $R^{2}-$

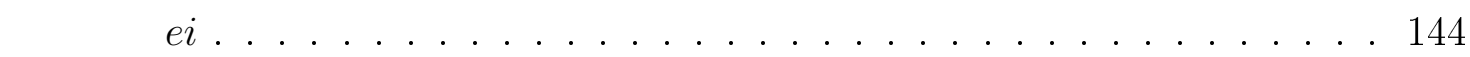

5.3. A becslés során kipróbált folytonos változók leíró statisztikái: átlagok 166

5.4. A becslés során kipróbált folytonos változók leíró statisztikái: átlag, medián, szórás. . . . . . . . . . . . . 167

5.5. A becslés során kipróbált dummy-változók . . . . . . . . . . . . 168

5.6. A kipróbált folytonos változók közötti korreláció . . . . . . . . . . 169

5.7. A logit-becslés eredménye . . . . . . . . . . . . 170

5.8. A modell illeszkedése . . . . . . . . . . . . . . . . 170

5.9. A PTI változó kihagyásával kapott átlagos parciális hatások .. 171

5.10. A hatékonysági becslésekhez felhasznált változók és számításuk módja 173

5.11. A Lerner-indexek számítása során felhasznált árjellegú változók 177

5.12. A költség- és profithatékonysági becslés során felhasznált változók leíró statisztikái (az állományok millió Ft-ban szerepelnek) . . . . 178

5.13. Becslési outputok, célváltozó: profit hitelezési veszteségekkel együtt 180

5.14. Becslési outputok, célváltozó: költségek hitelezési veszteségekkel együtt181 
5.15. Becslési outputok, célváltozó: profit ～. . . . . . . . . . . . . . 182

5.16. Becslési outputok, célváltozó: költségek . . . . . . . . . . . . . 183

5.17. Becslési stastisztikák, célváltozó: profit hitelezési veszteségekkel együtt184

5.18. Becslési stastisztikák, célváltozó: költségek hitelezési veszteségekkel együtt . . . . . . . . . . . . . . . . 185

5.19. Becslési stastisztikák, célváltozó: profit . . . . . . . . . . . . . 185

5.20. Becslési stastisztikák, célváltozó: költségek . . . . . . . . . . . . 185 


\section{Ábrák jegyzéke}

1.1. Lakáscélú és fogyasztási hitelek árfolyamszûrt állománya . . . . . 17

1.2. Vállalati hitelek árfolyamszû́rt állománya . . . . . . . . . . . . . . 20

2.1. Pénzügyi faktorok . . . . . . . . . . . . . . . . 36

2.2. Makrogazdasági faktorok . . . . . . . . . . . . . . . . 39

2.3. A pénzügyi faktorok volatilitása . . . . . . . . . . . . . . . . 41

2.4. Pénzügyi kondíciós index index . . . . . . . . . . . . . . 48

3.1. Nemteljesítô hitelek aránya különbözố hiteltípusoknál . . . . . . . . 73

3.2. A nemteljesítő hitelek aránya a különbözô időszakokban felvett háztartási deviza jelzáloghiteleknél . . . . . . . . . . 76

3.3. A hosszú távú PD a PTI függvényében különböző denomináció és jövedelem mellett . . . . . . . . . . . . . . . 82

3.4. NPL-arány alakulása a válság alatt a régióban . . . . . . . . . . 83

4.1. Az értékvesztés eredményrontó hatása az összes eszköz arányában az EU országaiban . . . . . . . . . . . . . . 9 98

4.2. A hazai bankok költséghatékonyságának becslése SFA és DEA költségfüggvény alapján . . . . . . . . . . . . . . 113

4.3. A hazai bankok profithatékonyságának becslése SFA és DEA költségfüggvény alapján. . . . . . . . . . . . . . . 114 
4.4. Becsült Lerner-indexek a vállalati hitelpiacon . . . . . . . . . . . . . 117

4.5. Becsült Lerner-indexek a háztartási hitelpiacon ....... 119

4.6. Az újonnan szerződött hitelek pénzpiaci kamatok feletti átlagos fel-

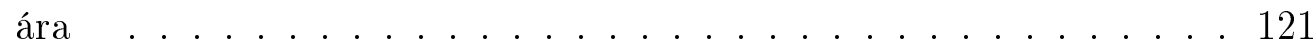

5.1. A pénzügyi faktorok konfidenciaintervallumokkal . . . . . . . . 146

5.2. Az elsố és a második makrofaktor konfidenciaintervallumokkal . . . 146

5.3. A harmadik és a negyedik makrofaktor konfidenciaintervallumokkal 147

5.4. Pénzügyi faktorok robusztussága a becsült faktorok számára . . . . 147

5.5. A makrofaktorok volatilitása . . . . . . . . . . . . . . 148

5.6. A makrofaktorok impulzusválaszai egy hitelezési hajlandósági sokk esetén . . . . . . . . . . . . . . . . . . 149

5.7. A makrofaktorok impulzusválaszai egy hitelezési hajlandósági sokk esetén . . . . . . . . . . . . . . . 150

5.8. A makrofaktorok impulzusválaszai egy hitelezési képességi sokk esetén ......................... 151

5.9. A makrofaktorok impulzusválaszai egy hitelezési képességi sokk ese-

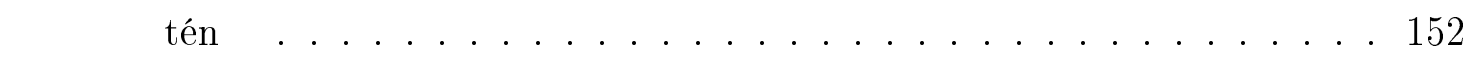

5.10. A hitelállományok- és kamatok impulzusválaszai egy hitelezési hajlandósági sokk esetén . . . . . . . . . . . . . . 153

5.11. A főbb GDP-tételek és az ipari termelés impulzusválaszai egy hitelezési hajlandósági sokk esetén . . . . . . . . . . . . 154

5.12. Foglalkoztatás, államkötvényfelár és árak impulzusválaszai egy hitelezési hajlandósági sokk esetén . . . . . . . . . . . . 155

5.13. A hitelállományok- és kamatok impulzusválaszai egy hitelezési képességi sokk esetén . . . . . . . . . . . . 156

5.14. A főbb GDP-tételek és az ipari termelés impulzusválaszai egy hite-

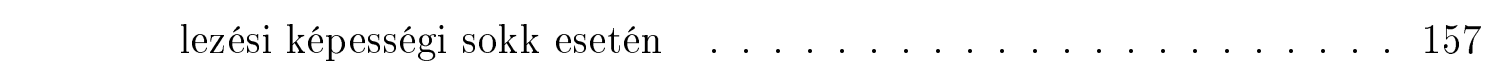


Ábrák jegyzéke

5.15. Foglalkoztatás, államkötvényfelár és árak impulzusválaszai egy hitelezési képességi sokk esetén . . . . . . . . . . . . . . . . 158

5.16. A hitelállományok- és kamatok impulzusválaszai egy hitelezési hajlandósági sokk esetén 2013 IV. negyedévében (robusztusság vizsgálat $\ldots \ldots \ldots \ldots \ldots \ldots \ldots \ldots$

5.17. A fóbb GDP-tételek és az ipari termelés impulzusválaszai egy hitelezési hajlandósági sokk esetén 2013 IV. negyedévében (robusztusság

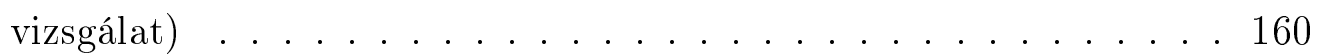

5.18. Foglalkoztatás, államkötvényfelár és árak impulzusválaszai egy hitelezési hajlandósági sokk esetén 2013 IV. negyedévében (robusztusság

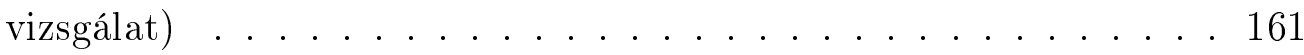

5.19. A hitelállományok- és kamatok impulzusválaszai egy hitelezési képességi sokk esetén 2013 IV. negyedévében (robusztusság vizsgálat)

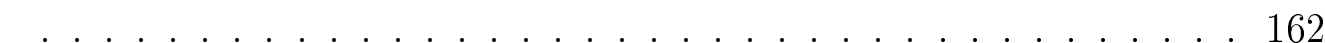

5.20. A föbb GDP-tételek és az ipari termelés impulzusválaszai egy hitelezési képességi sokk esetén 2013 IV. negyedévében (robusztusság vizsgálat) . . . . . . . . . . . . . . . 163

5.21. Foglalkoztatás, államkötvényfelár és árak impulzusválaszai egy hitelezési képességi sokk esetén 2013 IV. negyedévében (robusztusság vizsgálat $) \ldots \ldots \ldots \ldots \ldots$. . . . . . . . . . . 164

5.22. A DEA modellek szemléltetése: egy input, két output . . . . . . . 186

5.23. A DEA modellek szemléltetése: a mérethozadék szerepe . . . . . . . 187 


\section{1. fejezet}

\section{Bevezetés és történeti áttekintés}

\subsection{Bevezetés}

A 2008-ban kezdődô válság, majd az azt követő hitelszúke rávilágított arra, hogy a pénzügyi közvetítôrendszer és a pénzügyi piacok jelentôs hatást gyakorolnak a reálgazdasági folyamatok alakulására. Magyarországon a válság elmélyülésében és a kilábalás elhúzódásában ráadásul fontos szerepe volt a lakossági devizahitelezésnek, amely a háztartási szektor eladósodottságán és a magas nemteljesítô állományokon keresztül mérsékelte a belsô fogyasztás élénkülését. Ezért a válság után a korábbi időszakokhoz képest jobban előtérbe került a bankrendszer és a pénzügyi piacok helyzetének, stabilitásának figyelemmel követése. A makrogazdasági döntéshozók és szabályozók is nagyobb jelentôséget tulajdonítanak döntéseik során e szektort érintô változásoknak és azok tovagyưrúzô hatásainak. Ahogy a gazdasági döntéshozatalba, úgy a kutatások középpontjába is egyre többször kerülnek a bankrendszer és a pénzügyi piacok múködésével és hatásmechanizmusaival kapcsolatos kérdések.

A makroprudenciális politika célja, hogy a bankok múködéséból fakadó rendszerszintú kockázatok felépülését és pénzügyi válságok kialakulását megakadályozza, valamint biztosítsa, hogy a pénzügyi közvetítő rendszer megfelelően támogassa a gazdaság bôvülését. Mivel ezt a szabályozói problémakört a válság hívta életre, eszközrendszere még kiforratlan, tesztelésére és az intézkedések hatásosságának mérésére még nem, vagy csak nagyon korlátozott mértékben volt lehetôség mind 
magyar, mind világviszonylatban. Ugyanakkor a téma aktualitása és makrogazdasági szinten is érzékelhető hatása miatt a makroprudenicális politikához kapcsolódó kérdések nagy érdeklődésre tartanak számot.

Az értekezés témáját tekintve három modell segítségével tárja fel a magyar bankrendszer múködését, elemzi az összefüggéseket, és segítséget nyújt makroprudenciális kérdések megválaszolásában. Mindhárom modellt magyar adatokon, ökonometriai eszközökkel becsültük, a szükséges adatokat a Magyar Nemzeti Bank biztosította. A bankrendszer elemzése és makroprudenciális eszközök vizsgálata rendkívül tág témakör, modelljeink segítségével ezen belül a hitelkínálat alakulását, annak makrogazdaságra gyakorolt hatását és túlhitelezési időszakok beazonosítását, a háztartási nemteljesítési valószínúségre ható tényezôket, valamint a makroprudenciális szempontból optimális jövedelemarányos törlesztôrészlet szintjét, végül pedig a bankrendszer hatékonyságát és a hitelpiacokon tapasztalható verseny intenzitását vizsgáltuk.

Az elsô modell az Economic Systems folyóiratban jelent meq]. Az értekezés ezen fejezetében egy idôben változó paraméterú FAVAR modell segítségével két hitelkínálati faktort számítottunk, melyek közül az elsôt hitelezési hajlandóságként, a másodikat hitelezési képességként azonosítottuk. Majd megvizsgáltuk a kétfajta hitelkínálati sokk makrogazdasági változókra gyakorolt hatását, és ezek időbeli változását. A kétfajta hitelezési sokk meglehetôsen eltérô módon hat a makrováltozókra: egy pozitív hitelezési képességi sokk a GDP-t az országkockázat csökkenésén és a monetáris politikai lazításon keresztül befolyásolja, míg a hajlandóság fóleg a hitelezési aktivitást növeli. Időbeli változás szempontjából is eltér a két pénzügyi sokk egymástól: a hajlandóság hatásának változását fơleg egyszeri események mozgatták, így az eltérések általában rövid időszakokra jellemzôek. Ezzel szemben a hitelezési képesség esetén trendszerú folyamatok figyelhetôk meg: az országkockázat alakulásában egyre nagyobb szerepet játszott a bankrendszer helyzete a válság előtt, míg 2008 után úgy túnik, a monetáris politika növekvő mértékben vette figyelembe a pénzügyi stabilitást. Végül, becsléseink alapján egy újfajta pénzügyi kondíciós indexet számszerúsítettünk, amely a bankrendszer hitelezési tevékenységének GDP-növekedésre gyakorolt hatását méri. A három modell közül azért ezzel

${ }^{1}$ Hosszú (2018) 
kezdjük témánk tárgyalását, mert ennek segítségével általánosabban képet kaphatunk a magyar bankrendszer múködéséről. A másik két modell specializáltabban egy piacra vagy egy szúkebb kérdésre koncentrál.

A második modell az Acta Oeconomicában jelent meg² 2013 augusztusában a Magyar Nemzeti Bank egy felmérést végzett az eladósodott háztartások körében. Ezen felmérés adatainak felhasználásával két kérdésre kerestük a választ: mely tényezôk hatnak szignifikánsan a nemteljesítési valószínúségre; illetve, hitelezési kockázatok szempontjából hogyan lehetne optimális, jövedelemarányos törlesztőrészletre vonatkozó szabályozást kalibrálni. Eredményeink szerint a háztartás jövedelmi és munkapiaci helyzete, eladósodottsága, valamint a hitel denominációja és a hitelhez jutás módja egyaránt hatással van a hitelezési kockázatokra. Jövedelemarányos törlesztôrészletre vonatkozó előírás esetén pedig érdemes differenciáltan kezelni hiteldenomináció és jövedelem szerint a háztartásokat.

A harmadik rész a Magyar Nemzeti Bank MNB-tanulmányok sorozatában jelent meg ${ }^{3}$, valamint az Acta Oeconomica címú folyóiratban elfogadták publikálásra. Ebben egyrészt több modell segítségével megbecsültük a magyar bankok hatékonyságát, másrészt Lerner-indexet számítottunk külön a háztartási, illetve a vállalati hitelpiacra. A banki hatékonyság megbecslését SFA (stochastic frontier analysis) és DEA (data envelopment analysis) modellek segítségével is elvégeztük, valamint profit- és költséghatékonyságot is számítottunk a hitelezési veszteségek figyelembe vételével, illetve a nélkül. Eredményeink szerint költséghatékonyság szempontjából a bankrendszer közel homogén, és a válság hatására javulást mutatott. Profithatékonyság alapján azonban már jelentôsen heterogének a bankok, rendszerszinten a válság időszakában először visszaesés, majd folyamatos javulás figyelhetô meg. Mivel a háztartási és a vállalati hitelpiac múködési feltételei eltérôek, külön becsültük meg a verseny intenzitását a két piacon: a háztartási hitelpiacon a Lerner-index magas piaci erôt és gyenge versenyt mért, míg a vállalati hitelpiacot erôs verseny jellemezte.

Az értekezés felépítése a következő: a bevezetés után egy rövid történeti áttekintést adunk a háztartási és a vállalati hitelpiac fontosabb történéseirôl, amelyekre

$\sqrt[2]{\text { Balás et al. (2015) }}$

${ }^{3}$ Dancsik és Hosszú (2017) 
A magyar bankrendszer makroprudenciális szempontból

a késôbbiekben is hivatkozni fogunk. Ezután a három ökonometriai modell bemutatása következik, végül összegezzük az értekezés legfontosabb eredményeit.

\subsection{A magyar bankrendszer elmúlt 15 évének rövid áttekintése}

\subsubsection{Háztartási hitelezés, és az ehhez kapcsolódó kormány- zati intézkedések}

A háztartási hitelezés $\}^{4}$ Magyarországon a 2000-es évek elején indult el igazán, amikor a kormányzat kamattámogatással segítette a háztartások lakáshoz jutását. Ez a pogram 2003-ban zárult le, ezeket a forintban denominált hiteleket alacsony hitelkockázat jellemezte, még a válság során is csak kis százalékuk vált nemteljesítôvé, a bankoknak pedig stabil jövedelemforrást jelentettek.

2004-től kezdődően jelentős túlfútöttség alakult ki a háztartási hitelpiacon. A magas forintkamatok miatt a hitelek nagy részét ebben az időszakban devizában vették fel az ügyfelek, elsôsorban svájci frank és euró alapú konstrukciókban, miközben deviza bevételeik nem voltak. Ezen hitelek ráadásul változtatható kamatozásúak voltak, ami azt jelentette, hogy a bank bármikor egyoldalúan megváltoztathatta a hitel után fizetendô kamatot. Az idôszak elején fóleg lakáscélú hiteleket helyeztek ki ilyen konstrukcióban, azonban késôbb a devizaalapú, szabadfelhasználású jelzáloghitelek mennyisége is nagy mértékben nőtt. Különösen 2007-tôl kezdődően, a banki hitelezési sztenderdek fellazultak, és olyan alacsony jövedelmú, bizonytalanabb munkapiaci helyzetben lévố háztartások is hitelhez juthattak, akik korábban likviditási korlátokkal szembesültek. Így kialakult egy olyan portfólió, amely a korábbinál sokkal magasabb nemteljesítési valószínúséggel rendelkezett, ráadásul mind az árfolyam-, mind a kamatkockázatot a háztartások viselték.

\footnotetext{
${ }^{4}$ Makrogazdasági szempontból és az értekezés további fejezetei kapcsán a háztartási hitelállományon belül elsôsorban a jelzáloghitelekkel kapcsolatos kérdések állnak az érdeklődés középpontjában, így a történeti áttekintés során is ezekre koncentrálunk.
} 
1.1. ábra: Lakáscélú és fogyasztási hitelek árfolyamszûrt állománya

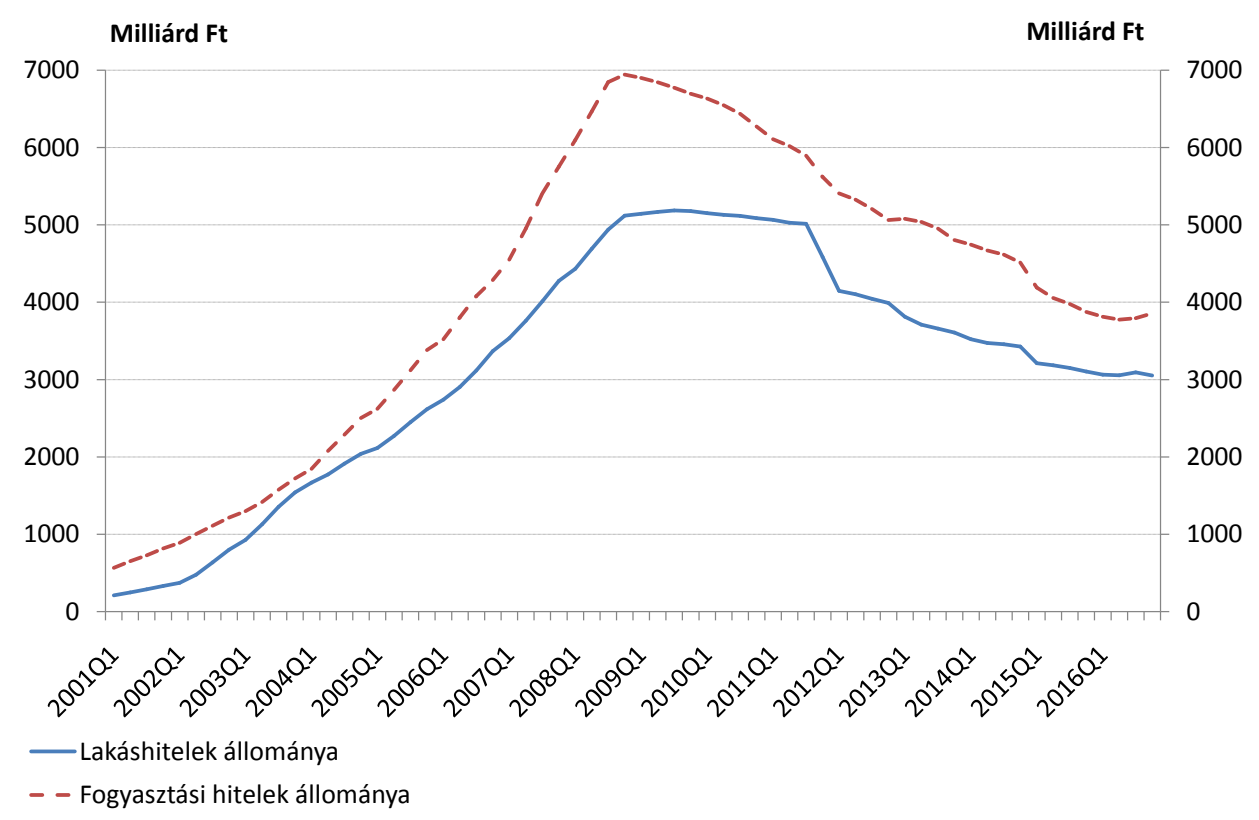

Forrás: MNB

2008 ôszén a devizahitelek már a háztartási hitelek kétharmadát tették ki. A válság hatására a forint többször is nagy mértékben leértékelődött, megnôtt a munkanélküliség, drasztikusan csökkentek a lakásárak, amely a háztartási NPLállomány rohamos emelkedéséhez vezetett. A bankok hitelezési veszteségeik fedezésére növelték a teljesítő hitelállomány kamatait, ezzel további terheket róva az adósokra. A háztartások ezért visszafogták fogyasztási kiadásaikat, ami tovább mélyítette a válság okozta recessziót. Mivel a túladósodás több százezer háztartást érintett, a kormányzat több intézkedést is hozott a devizahitelesek problémájának kezelésére. Ezek közül a témánk tárgyalása szempontjából kevésbé fontos az árfolyamgát program, a Nemzeti Eszközkezelô által felvásárolt lakások és a magáncsőd intézménye. Azon intézkedéseket ellenben részletesebben bemutatjuk, amelyekre 
az értekezés során hivatkozni fogunk, ezek: kedvezményes végtörlesztés, tisztességtelen kamatemelések elszámolása, forintosítás.

Kedvezményes végtörlesztés: A kormány a magas devizakitettség miatti sérülékenység csökkentése érdekében a devizajelzálog-hitellel rendelkezô ügyfelek számára lehetôvé tette a kedvezményes árfolyam melletti végtörlesztést. Ebben az idôszakban a svájci frank-forint árfolyam 245 körül mozgott, ehelyett az ügyfeleknek 180-as átváltási arány mellett nyílt lehetôségük a végtörlesztésre. Az árfolyamkülönbségből fakadó veszteségek a bankokat terhelték. A program 2011 utolsó és 2012 elsô negyedévét érintette, 1350 milliárd forint értékú hitelt törlesztettek ekkor, ami a fennálló állomány 24 százalékát tette ki.

Tisztességtelen kamatemelések elszámolása: 2014 júniusában a Kúria döntése a változtatható kamatozású hitelkonstrukciókat tisztességtelennek nyilvánította, ezért szeptemberben a Parlament törvényt alkotott arról, hogy a bankoknak vissza kell fizetniük az ügyfeleknek az egyoldalú kamatemelésekból származó bevételeiket. Ennek módja: „az adósok tisztességtelen feltételek következtében fellépô túlfizetéseit visszamenôleg tôke-előtörlesztésként kell figyelembe venni a folyószámla-, hitelkártyahiteleken és az állami kamattámogatású hiteleken kívül minden hitelre, melyet 2004. május 1. után nyújtottak, illetve 2009. július 26. előtt nem szúnt meg. A fogyasztói követelés mértékét - vagyis az árfolyamrés és a tisztességtelen szerződésmódosítások elszámolásának költségét - az eredeti és az így átszámított fennálló tôketartozás közti különbség, valamint az eredeti és átszámított lejárt tartozások közötti különbség adja. Még élő szerződések esetében az így kiszámolt összeget elôbb a lejárt tartozások, majd a fôtartozás terhére kell elszámolni” MNB (2014). Az elszámolások fóleg 2014 utolsó negyedévében zajlottak, mintegy 600 milliárd forintos veszteséget okozva a bankrendszernek.

Forintosítás: Az elôzô intézkedés után, 2015 januárjától lépett életbe, célja a háztartási jelzálogportfólió árfolyamkockázatának megszűntetése volt. Mintegy 3500 milliárd forintnyi devizahitel-állományt váltottak át forinthitellé, amelyeknél a hitelszerződések maximális kamatát törvény szabályozta. (További részletek a programról: MNB (2014).) Az így létrejött új forinthiteleknél az árfolyamkockázat megszünésén felül a kamatkockázat is csökkent, mivel a változtatható kamatozású 
termékekrôl át kellett térni egy referenciakamathoz kötött változó kamatozású vagy fix kamatozású termékre.

A válság előtti túlzott eladósodás 2008-tól kezdődően a háztartásokat mérlegalkalmazkodásra kényszerítette, így (az árfolyamszưrt) hitelállomány folyamatosan csökkent a 2016-os fordulópontig. Ekkora egyrészt a devizahiteles háztartások problémáját a kormányzat a bankokkal közösen részben kezelte. Másrészt a konjunkturális és monetáris folyamatok kedvezően hatottak a hitelezésre is, mivel az egyre alacsonyabb alapkamat, a növekvő bérek és foglalkoztatás hatására nôtt a hitelképes ügyfelek száma. Harmadrészt a növekvő lakásárak felgyorsították a nemteljesító hitelek tisztítását a banki portfóliókból, így a hitelkínálat is javulni kezdett, valamint a lakáshitelek iránti kereslet is élénkült. Ezek eredőjeként 2016 második felétôl a háztartási hitelállomány már mérsékelten növekedett.

\subsubsection{A vállalati hitelezés alakulása az elmúlt 15 évben}

A vállalati hitelállomány felépülése már korábban megkezdődött, mint a háztartási hitelek esetén, azonban a késôbbiekben felhasznált adataink ebben az esetben sem nyúlnak vissza a 2000-es éveknél korábbi idôszakokra, így a rövid történeti áttekintésünk sem. A vállalati hitelezés Magyarországon kiemelt jelentőséggel bír, mivel a vállalatok (különösen a hazai tulajdonban lévô kis- és középvállalatok) külsố pénzügyi forrásokhoz döntôen banki hitelek formájában férnek hozzá, az egyéb pénzügyi piacokról történô forrásbevonás mértéke elenyészô. Ebból kifolyólag a nemzetgazdasági termelés, foglalkoztatás és beruházás alakulását is nagy mértékben befolyásolja, hogy mekkora összegú hitelhez milyen feltételek mellett az ügyfelek milyen széles köre fér hozzá.

A 2000-es évek elsô felét a vállalati hitelek esetén is a kiegyensúlyozott növekedés jellemezte. A hitelállomány a fóbb makrogazdasági aggregátumokkal együtt bôvült, miközben a bankok hitelezési vesztesége nem volt jelentős. A vállalati hitelek esetén is megjelentek a devizahitelek, sôt, ebben az esetben is az állomány érdemi részét tették ki (és teszik ki jelenleg is). Ez azonban a vállalatok esetében részben természetes jelenségnek tekinthetô: az exportra termelő vállalatok az árfolyamkockázatot azzal csökkenthetik, ha hiteleiket abban a devizában veszik fel, 
1.2. ábra: Vállalati hitelek árfolyamszûrt állománya

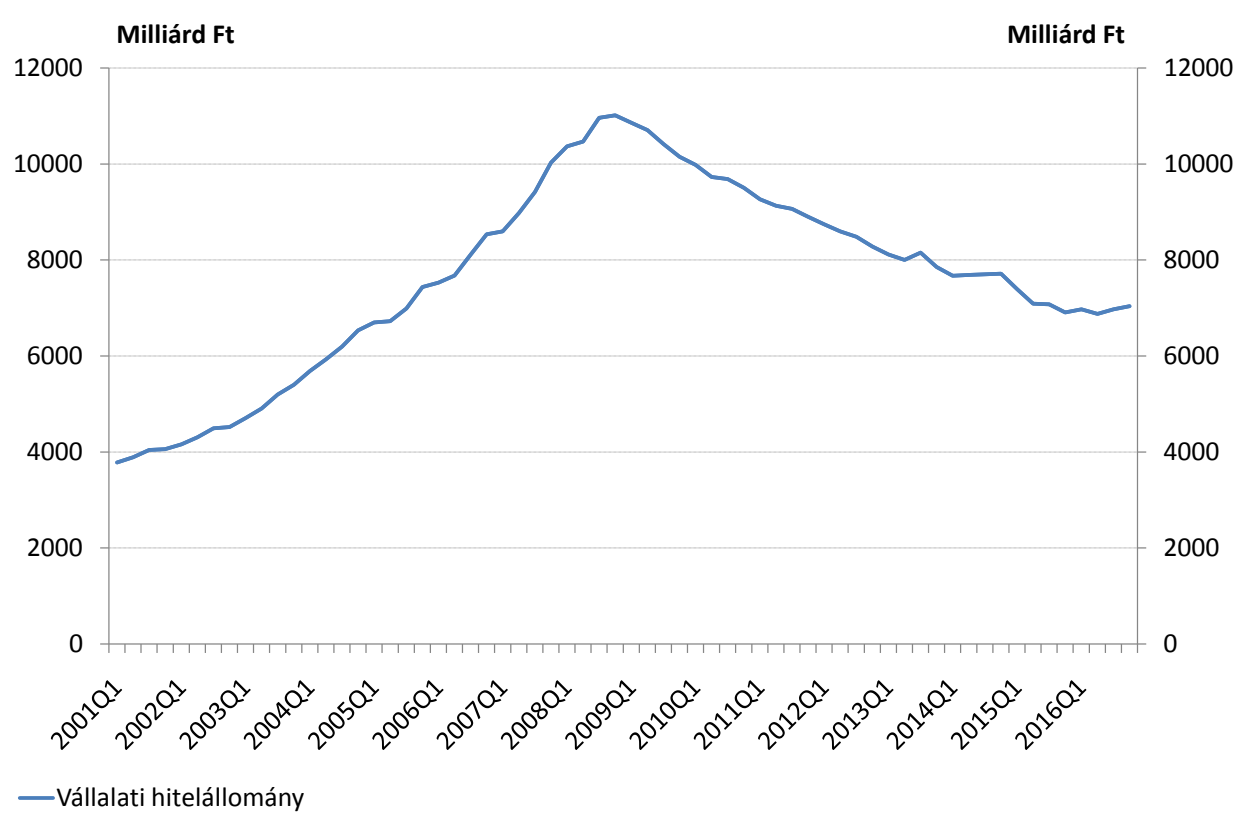

Forrás: MNB

amelyben a bevételeik is keletkeznek (ez a deviza Magyarország esetén elsôsorban az euró). Így a vállalati devizahitelek állományán belül az euróban denominált hitelek váltak a legelterjedtebbé.

A 2000-es évek második felében a vállalati hiteleken belül is megkezdődött a túlzott kockázattal járó állomány felépülése. A válság után a bankok a legnagyobb veszteségeiket ebben a szegmensben az ingatlanprojekt-hiteleken szenvedték el, mivel ezek a projektek a lakáspiac és a lakossági fogyasztás visszaesésével sok esetben még a tőketartozást sem voltak képesek kitermelni. Tovább rontott a helyzeten, hogy a magas forintkamatok következtében sok esetben devizában, azon belül is svájci frankban vették fel a hiteleket, holott a bevételek döntôen forintban, eset- 
leg euróban keletkeztek. A portfóliótisztítás ezen állománynál is lassú és rendkívül költséges folyamat volt, így hosszú évekig magas NPL-ráták[5jellemezték a szektort.

A válság és a számos nemteljesítôvé váló hitel hatására 2008 után a bankok hitelkínálata jelentôsen visszaesett, a hitelhez jutás feltételeit megszigorították a forgóeszköz és a beruházási hitelek esetén is. Ez tovább mélyítette a recessziót, mivel így a vállalatok bôvülését a hitelkorlátok is nehezítették. A nagyvállalatok és a külföldi anyavállalattal rendelkező cégek a hazai banki források szúkülését pótolhatták külföldi vagy az anyavállalattól felvett hitellel, azonban a hazai tulajdonú kkv-knak erre nem volt lehetôsége. A Magyar Nemzeti Bank a hitelkínálat helyreállításának érdekében 2013-ban indította Növekedési Hitel Programját (NHP), amelynek keretében a bankok az MNB-tôl olcsón jutottak forráshoz, amelyet a piaci kamatokhoz képest szintén olcsón helyezhettek ki kkv-knak. ${ }^{6}$ 2016-ra a javuló konjunkturális kilátások, a kedvezô monetáris kondíciók és az MNB programjainak hatására a vállalati hitelállomány is ismét bôvült.

\footnotetext{
${ }^{5} \mathrm{NPL}$ : non-performing loans, a nemteljesítô hitelek állományának aránya.

${ }^{6}$ Az NHP-t további hitelkínálat-ösztönzô programok követték, ezekrôl részletesen lásd: Bodnár et al. (2017)
} 


\section{2. fejezet}

\section{Hitelkínálati sokkok hatása és egy új pénzügyi kondíciós index egy FAVAR modell alapján}

\subsection{A kapcsolódó irodalom áttekintése}

A pénzügyi folyamatok jellemzésére számos szempont és idősor áll rendelkezésre, azonban kérdésként merült fel, hogy ezek információtartalmát lehet-e és milyen módon lehet egy-két jól értelmezhetô mutatóba sưríteni. Az ilyen információtömörítô mutatókat hívja a szakirodalom pénzügyi kondíciós indexnek (a továbbiakban röviden PKI), amelyek a pénzügyi piacok általános helyzetéról adnak képet. Minden PKI bizonyos pénzügyi idősorok összesúlyozásából jön létre, azonban kiszámításuk sokat változott az évek folyamán. Ezek az indexek egyre szélesebb információs halmazból (akár több száz idősorból) indulnak ki. Továbbá, míg az összesúlyozás kezdetben az egyszerú átlagolás volt, a legújabb PKI-k már különböző becslési eljárásokból származnak, amelyek például a makrogazdaságra gyakorolt hatásokat veszik figyelembe.

A disszertáció jelen része a magyar pénzügyi közvetítôrendszerre vonatkozóan mutatja be a PKI egy lehetséges, új számítási módját, méghozzá időben változó 
A magyar bankrendszer makroprudenciális szempontból

paraméterú, faktorokkal kiegészített vektor-autoregresszív (factor augmented vector autoregression, továbbiakban röviden FAVAR) modell segítségével. A magyar pénzügyi közvetítôrendszer sajátosságait figyelembe véve több szempontból is eltérünk az irodalomban fellelhető PKI-któl: elôször is, a pénzügyi faktorok becslésénél csak a bankrendszert leíró mutatókat veszünk figyelembe. Ugyanakkor egy banki paneladatbázist használunk, mivel a bankrendszeri alapfolyamatokat viszont minél pontosabban szeretnénk feltárni. Másodszor - bár ez nem példa nélküli - időben változó paraméterú becslést végeztünk, mivel egyrészt egy rendkívüli esemény - a válság - is része a megfigyelt periódusnak, másrészt a válság következtében számos, a bankrendszert alapjaiban érintô szabályozói változás történt ebben az idôszakban, ami szintén átalakíthatta a bankrendszer és a reálgazdaság közötti összefüggéseket. Harmadszor, egyesítettünk két korábbi PKI-számítási módszert: a faktorelemzés során kapott faktorok reálgazdaságra (egész pontosan GDP-növekedésre) gyakorolt hatását neveztük el PKI-nak.

A FAVAR-ból kapott eredményeket továbbá hitelkínálati sokkok hatásának vizsgálatára is felhasználtuk. Két pénzügyi faktort különböztettünk meg, az egyiket hitelezési hajlandóságként, a másikat hitelezési képességként azonosítottuk. A makrogazdasági változókból is faktorokat számítottunk, majd a kétfajta faktorokat egy VAR-modellben vizsgáltuk, így a hitelkínálati sokkok hatását a makrováltozók széles körén tudtuk mérni. Mindkét faktor érdemben befolyásolja a makrogazdasági változók alakulását, azonban eltérő módon. Az általunk használt modellel arra is választ kaptunk, hogy hogyan változott a hitelkínálati sokkok valószínúsége, illetve hatása a vizsgált időszakon.

Legfontosabb eredményeink a következők: a hitelezési képességi sokk hasonló egy negatív kockázati felár sokkhoz, a GDP-t az országkockázat csökkenésén és a monetáris politikai lazításon keresztül befolyásolja. A hitelezési hajlandósági sokk fôleg a hitelezési aktivitásra gyakorol hatást, ráaádsul egy képességi sok általában perzisztensebb, míg egy hajlandósági sokk hamar lecseng. Időbeli változás szempontjából is eltér a két pénzügyi sokk egymástól: a hajlandóság hatásának változását a devizahitelezés, valamint egyszeri események (például válság kitörése) mozgatták, így az eltérések általában rövid időszakokra jellemzőek, ráadásul kismértékűek a különbözô negyedévek között. Ezzel szemben a hitelezési képes- 
2. fejezet. Hitelkínálati sokkok hatása és egy új pénzügyi kondíciós index egy FAVAR modell alapján

ség esetén trendszerü folyamatok figyelhetők meg: az országkockázat alakulásában egyre nagyobb szerepet játszott a bankrendszer helyzete a válság előtt, míg 2008 után úgy tûnik, a monetáris politika növekvô mértékben vette figyelembe a pénzügyi stabilitást. A VAR hibatagok varianciájának idóbeli változása alapján az is elmondható, hogy a válság következtében nôtt a hitelkínálati sokkok várható mértéke, ez a jelenség a 2008 utáni szabályozói változásoknak köszönhetően tovább erôsödött.

A faktormodellek makroökonómiai célú alkalmazása az 1970-es évekre nyúlik vissza (lásd például Geweke (1977) vagy Sargent és Sims (1977)). E becslések alapötlete, hogy nagy dimenziójú, makrováltozókból álló paneladatokban lévô információk jól megjeleníthetôk néhány (az eredeti változók számánál jóval kevesebb) faktorban, amelyekkel a további számítások stabilabb eredményekre vezetnek. Azóta számos tanulmány jelent meg a faktormodellek különbözô típusairól, amelyeket egyre szélesebb körben alkalmaznak közgazdasági kérdések vizsgálatára is. Jelen tanulmányban a faktormodellek irodalmának csak azon részére szorítkozunk, amelyet PKI számításához vagy pénzügyi, illetve bankrendszeri sokkok hatásának számszerúsítéséhez használtak.

Módszertanilag a cikkek első csoportja a Stock és Watson (2002) cikkben bemutatott faktormodellt használja, amely a faktorokat főkomponens-elemzéssel számítja ki, majd a dinamikájukat egy VAR-modell segítségével jeleníti meg. A pénzügyi kondíciók és sokkok elemzése számos cikkben összekapcsolódik a monetáris politika vizsgálatával, illetve a kétfajta sokk elkülönítésével és összehasonlításával. Az elsô ezen cikkek sorában Bernanke et al. (2005) volt, amely az USA adatain becsülte meg a monetáris politikai sokkok más változókra gyakorolt hatását. A faktorok használatának köszönhetốen sokkal több idôsort voltak képesek bevonni a vizsgálatba, mint egy klasszikus VAR-modell esetén. A makrováltozókból számított faktorok mellett a rövid kamatot is szerepeltették a VAR-ban és Cholesky-dekompozíciót használtak az impulzusválaszok kiszámításához. Ehhez nagyon hasonló megközelítést használtak a szerzók a Boivin et al. (2013) és Pellényi (2012) tanulmányokban, előbbi a hitelezési sokkok hatását vizsgálta az USA adatain, utóbbi a monetáris politika hatásának ágazatok szerinti heterogenitását magyar adatokon. Az eltérés a sokkdekompozíció módszertanában volt: a faktorokhoz használt eredeti változók- 
ra alkalmazott előjelmegkötésekkel identifikálták a kérdéses sokkokat. Jimborean és Mésonnier (2010) a monetáris politika bankimérleg-csatornáját számszerúsítette Franciaország esetében, ehhez főkomponens-elemzéssel számolt pénzügyi és makro faktorokat, amelyek (és az alapkamat) egymásra hatását egy VAR-modellben vizsgálta. A sokkok identifikálása ebben az esetben az alapkamat impulzusválaszaira tett előjelmegkötéssel történt. Az előbbiekkel ellentétes irányú kérdést, a makrogazdasági sokkok bankrendszerre, és egyedi bankokra gyakorolt hatását vizsgálta Buch et al. (2014), azonban a becslési eljárás itt is azonos.

A 2000-es évek második felétôl egyre népszerúbbek lettek az idôben változó paraméterú FAVAR modellek (lásd például: Del Negro és Otrok (2008), Eickmeier et al. (2011a), Korobilis (2013)). A cikkek eredményei alapján ez jogosnak bizonyult: szignifikáns különbségeket találtak a modellek paramétereiben különbözô idôszakokat vizsgálva. A konkrét modellspecifikációkban ezen a csoporton belül sokkal nagyobb eltérések vannak a különbözô cikkekben. Más-más feltételezésekkel élnek arra vonatkozóan, hogy a modellnek mely típusú paraméterei változnak idôben, illetve bayesi vagy klasszikus eljárással (és azon belül is pontosan milyen módon) történt a becslés. A nemzetközi pénzügyi sokkok hatásmechanizmusát vizsgálja az Eickmeier et al. (2011b) tanulmány egy klasszikus módon becsült változó paraméterú FAVAR modellel. A szerzôk arra jutnak, hogy a sokkok mérete és hatása is eltérô a különböző idôszakokban (elsôsorban a 2008-as válságot hasonlították össze korábbi idôszakokkal). Hasonlóan fontosnak találja az idôbeli változás figyelembe vételét a reálgazdaság és a pénzügyi közvetítôrendszer kapcsolatának vizsgálatakor Prieto et al. (2013) tanulmány, amely egy bayesi VAR modell alapján jut erre az eredményre.

A pénzügyi kondíciós indexek módszertana sokat változott az utóbbi években: az elsô PKI-k a legfontosabb pénzügyi mutatók egyszerú átlagaként jöttek létre (lásd EKB (2009), IMF (2008)). A második generációs PKI-mutatók már abban fejlettebbek voltak, hogy a különbözô pénzügyi idôsorokat a makrogazdaságra elsôsorban a GDP-re - gyakorolt hatásuk alapján súlyozták össze (ebbe a csoportba tartozott például Swiston (2008), Beaton et al. (2009), melyeket az USA adatain becsültek). A makrogazdaságra gyakorolt hatást egy strukturális VAR együtthatói és impulzusválaszai alapján becsülték meg. 
2. fejezet. Hitelkínálati sokkok hatása és egy új pénzügyi kondíciós index egy FAVAR modell alapján

A PKI számítására alkalmazott legújabb módszer a fókomponens-, illetve faktorelemzés, amelyeknek elônye a korábbiakhoz képest, hogy széles információs halmazt használnak fel, így teljesebb képet adhatnak a pénzügyi közvetítőrendszer folyamatairól. Az elsô, úttörő tanulmány ezen a téren Hatzius et al. (2010), amely szintén az USA-ra becsült PKI-t. A pénzügyi mutatókra először egyenként regressziókat illesztettek, melyekben magyarázóváltozóként a GDP-növekedés és az infláció késleltetettjeit használták (ezzel próbálták a pénzügyi idôsorokból szứrni a makrogazdaság endogén hatását). A regressziók hibatagjaiból kiszámították az elsô főkomponenst, ezt tekintették PKI-nak. Stock és Watson (2002) módszertanát használva számít FCI-t az Eurozóna adataira Darracq Pariès et al. (2014) majd az így kapott FCI és egy VAR modell segítségével pénzügyi sokkok hatásait is számszerúsítik. Állapottér modellek segítségével becsült az USA és az Eurozóna adataira dinamikus faktorokat Brave és Butters (2011), illetve Matheson (2012). Számításaik során a Doz et al. (2012) és Doz et al. (2011)-ben szereplő becslési eljárást használták, ezek elônye, hogy eltérô frekvenciájú idôsorokat és hiányzó adatokból fakadó problémákat is képes kezelni. Az általunk használt PKI módszertana Koop és Korobilis (2014) megközelítésén alapul. A szerzők a Doz et al. (2011)-ben olvasható becslési eljárást általánosították változó paraméterú esetre, valamint a PKI-hoz használt változók közül úgy válogattak, hogy a létrejövô PKI előrejelzési képessége a lehetô legjobb legyen.

Végül itt kell megemlítenünk Tamási és Világi (2011) tanulmányt, amely ugyan nem faktormodell, de egy bayesi SVAR modell segítségével a hitelkínálati sokkok hatását becsli meg magyar adatokon, így az általunk kapott eredményekhez hasznos összevetésként szolgál majd.

\subsection{Adatok és módszertan}

\subsubsection{Pénzügyi és makrogazdasági adatok}

Ahogy már a bevezetőben is említettük, külön számítottunk faktorokat egy pénzügyi és egy makrogazdasági adathalmazból. A pénzügyi faktorok esetén úgy dön-

\footnotetext{
${ }^{1} \mathrm{~A}$ módszerról részletesebben írunk majd a 3 . fejezetben.
} 
töttünk, hogy csak bankrendszeri adatokat használunk, méghozzá egy panel adatbázist, amely a tíz legnagyobb magyarországi bank adatait tartalmazza (egész pontosan kilenc bank idôsorait használtuk, a tizedik bank pedig a bankrendszer maradék része). Ez a megoldás eltér attól, amit általában a PKI számításakor alkalmazni szoktak. Azért ezt az eljárást választottuk, mert Magyarországon a pénzügyi közvetítôrendszer többi része és a pénzügyi piacok elhanyagolható szerepet játszanak a vállalati és a háztartási szektor forráshoz jutásában (lásd Banai (2016)). Így figyelmünket a banki hitelpiacokra összpontosítjuk: az itt bemutatott PKI-t nevezhetnénk akár banki kondíciós indexnek is, és a pénzügyi sokkok közül a hitelkínálati sokkok hatását vizsgáljuk. ${ }^{2}$ Mivel az adatok döntô többsége csak negyedéves frekvencián áll rendelkezésre, negyedéves adatokat, valamint a lehetô leghosszabb mintát használtuk, amelyen az adatok elérhetôek voltak, így idôsoraink 2001 második negyedévétôl 2015 második negyedévéig tartanak.

A bankok helyzetét leíró mutatók közül is azokra koncentrálunk, amelyek a hitelkínálattal állnak szorosabb kapcsolatban. Minden bankra vonatkozóan tíz idôsort vettünk figyelembe, ezeket tartalmuk alapján három csoportba lehet sorolni: szolvenciahelyzetet, likviditási helyzetet, illetve kockázatvállalást jellemzô mutatók. A szolvenciahelyzetet megragadó mutatókból a tôkeáttételt (mérlegfóösszeg az összes tôke arányában), a tôkepuffert (a mérlegfőösszeg arányában), illetve az anyabanki tôkeáttételt használtuk. A harmadik mutató szintén a magyar bankrendszer sajátosságaiból következik, nevezetesen, a bankrendszer túlnyomó többsége külföldi bankok tulajdonában van. Ezeknél a bankoknál az volt megfigyelhető, hogy tôkéból mindig csak annyit tartottak a magyar banknál, ami éppen eleget tett a szabályozói előírásoknak. Ha ez alá került a magyar bank tôkeszintje, pótolták a hiányzó részt (a témáról bôvebben ír Bethlendi (2007)). Így ezen, külföldi tulajdonú bankok szolvenciahelyzetét (és így a hitelezési potenciálját vagy szándékát) valójában jobban megragadja az anyabank tőkeellátottsága.3 A likviditási helyzetet három mutatóval ragadtuk meg: likvid eszközök, stabil források és devizaswap állományok mérlegfőösszeg-arányos értéke. Ezek közül is a harmadik változó szorul

${ }^{2}$ A PKI-val kapcsolatos irodalomban nem jellemzó a banki paneladatbázisok használata, ugyanakkor a pénzügyi sokkok hatásvizsgálatánál találunk erre is példát: Buch et al. (2014), Jimborean és Mésonnier (2010)

${ }^{3} \mathrm{~A}$ hazai tulajdonú bankoknál ezt a mutatót a saját tókeáttétel helyettesítette. 
2. fejezet. Hitelkínálati sokkok hatása és egy új pénzügyi kondíciós index egy FAVAR modell alapján

némi magyarázatra: a válság elôtt jelentôs devizahitelezés forássát a bankok devizaswapokból oldották meg, így likviditási szempontból felépülő kockázatok és a válság hatására kialakuló problémák is leginkább a devizaswapok alakulásán voltak tetten érhetők.

A kockázatvállalási mutatók közül kettô a múltban vállalt kockázatok realizálódására, és ezek hitelezést visszafogó hatására vonatkozik. Ezek az állományarányos értékvesztés eredményrontó hatása, illetve a háztartási és a vállalati nemteljesítô hitelek arányának (NPL) változása. Az aktuális kockázati étvágyat tükrözi jobban a kockázattal súlyozott eszközök, valamint a kamat- és jutalékjövedelem mérlegfőösszeg-arányos értékének alakulása. Ezek növekedése arra utaló jel, hogy a bank egy kockázatosabb hitelezési szegmens felé mozdult el. Az NPL-ráta kivételével minden mutatónak a szintjét vettük figyelembe, utóbbinak azért a változása került a modellbe, mert a stacionaritás (amely a faktorelemzés szükséges feltétele) így volt biztosítható.

A makrogazdasági faktorokhoz összesen harmincnégy, a magyar gazdasággal kapcsolatos legfontosabb információkat tartalmazó idôsort használtunk fel. Ezek között megtalálhatók többek között a GDP és résztételei, foglalkoztatási adatok, árak és deflátorok, bizalmi indikátorok, árfolyam, országkockázati mutató, hitelállományok, hitelkamatok és bankközi rövid kamat. (A teljes lista a Függelékben megtalálható a változókra alkalmazott transzformációkkal együtt.) Ahol szükséges volt, szezonálisan igazított adatokat használtunk.

\subsubsection{Időben változó paraméterü FAVAR}

Az adatok ismertetése után, most rátérünk a módszertan lényegi részének bemutatására, a jelölésekben ahol lehetett, követtük a Koop és Korobilis (2014) tanulmányban használtakat. Legyen $x_{t}(t=1, \ldots, T)$ a banki változók $n \times 1$-es $(n=100)$, $y_{t}$ a makro változók $s \times 1$-es $(s=34)$ vektora! A következő modellt szeretnénk 
megbecsülni:

$$
\begin{aligned}
y_{t} & =\lambda^{y} f_{t}^{y}+\mu_{t} \\
x_{t} & =\lambda_{t}^{f} f_{t}+\lambda_{t}^{D} y_{t}^{D}+v_{t} \\
F_{t} & =B_{t, 1} F_{t-1}+\cdots+B_{t, p} F_{t-p}+\epsilon_{t} \\
\lambda_{t}^{x} & =\lambda_{t-1}^{x}+\eta_{t} \\
\beta_{t} & =\beta_{t-1}+\nu_{t}
\end{aligned}
$$

4 mako és 2 pénzügyi faktort becsültünk, a VAR egyenletben a késleltetések száma kettő $(p=2)$. Az (1) egyenlet a makrováltozók és faktorok közötti kapcsolatot írja le, $\lambda^{y}$ a faktorloadingok $34 \times 4$-es mátrixa, $f_{t}^{y}$ a látens makrofaktorok $4 \times 1$-es vektora, $\mu_{t} \sim N(0, S)$ pedig $34 \times 1$-es vektor. Ahogy látható, azt feltételezzük, hogy a loadingok is és a hibatagok kovarianciamátrixa is idôben állandó, mivel úgy gondoljuk, lényeges változások ebben az időszakban elsôsorban a bankrendszerben, illetve a bankrendszer és a reálgazdaság egymásra gyakorolt hatásában voltak, így figyelmünket ezekre koncentráljuk.

A (2) egyenlet a pénzügyi faktorok és idősorok összefüggését mutatja, amelyben $\lambda_{t}^{f}$ a pénzügyi faktorok loadingjainak $100 \times 2$-es mátrixa, $f_{t}$ a pénzügyi faktorok $2 \times 1$-es vektora, $v_{t} \sim N\left(0, V_{t}\right)$ pedig $100 \times 1$-es vektor. A $(2)$ egyenlet bizonyos makrováltozókat is tartalmaz, amelyeket $y_{t}^{D}$ jelöl, amely egy $6 \times 1$-es vektor, és a GDP-növekedést, inflációt, az EUR/HUF árfolyam változását, valamint ezek késleltetett értékeit tartalmazza. A makrováltozók szerepeltetésével a makrogazdaság hatását szerettük volna kiszûrni a banki faktorainkból, hogy azok tisztán a banki hitelkínálatot mérjék ezzel csökkentve az endogenitási problémát. Ez az eljárás sztendernek mondható a PKI-t becslô modellek esetén, hasonló megoldást alkalmazott például Hatzius et al. (2010), Darracq Pariès et al. (2014) és Koop és Korobilis (2014), A makrováltozók $100 \times 6$-os együtthatóját $\lambda_{t}^{D}$-vel jelöltük. Mint látható, idóben változó loadingok és heteroszkedasztikus hibatagok feltételezésével éltünk ebben az esetben, ahol a loadingok változása többváltozós véletlen bolyongást követ, amelyet a (4) összefüggés ír le $\left(\lambda_{t}^{x}=\left[\lambda_{t}^{f}, \lambda_{t}^{D}\right]\right)$. A likelihood becslést tartalmazó irodalomban megszokott módon azzal a feltételezéssel éltünk, hogy $S$ és $V_{t}$ mátrixok diagonálisak, azaz $f_{t}^{x}$ és $f_{t}^{y}$ tartalmazza a pénzügyi és makro idôsorokban lévô közös információkat. 
2. fejezet. Hitelkínálati sokkok hatása és egy új pénzügyi kondíciós index egy FAVAR modell alapján

A különbözô típusú faktorokat egy vektorba rendezve: $F_{t}=\left[\begin{array}{l}f_{t}^{y} \\ f_{t}^{x}\end{array}\right]$ a faktorok $6 \times 1$-es vektora, ezeket a (3) egyenletben rakjuk egy közös VAR-modellbe, ahol $B_{t, 1}$ és $B_{t, 2}$ a VAR-együtthatók $6 \times 6$-os mátrixai, $\epsilon_{t} \sim N\left(0, Q_{t}\right)$. A VAR-együtthatókat és a hibatagok kovarianciamátrixait is idôben változó folyamatok írják le, az együtthatókra a loadingokhoz hasonlóan többváltozós véletlen bolyongást feltételezünk. Ezt írja le az (5) egyenlet, ahol $\beta_{t}=\left(\operatorname{vec}\left(B_{t, 1}\right)^{\prime}, \ldots, \operatorname{vec}\left(B_{t, p}\right)^{\prime}\right)^{\prime}$. A loadingok és a VAR-együtthatók változását megjelenítő egyenletek hibatagjai is nulla várható értékú együttes normális eloszlásból származnak, sorrendben $W_{t}$ és $R_{t}$ kovarianciamátrixokkal. Ha $\beta_{t}$ és $\lambda_{t}^{x}$ időben állandó lenne, egy heteroszkedasztikus FAVAR modellt, míg ha $V_{t}$ és $Q_{t}$ is konstans lenne egy klasszikus FAVAR modellt kapnánk.

Van néhány jelentős különbség az eredeti cikkben és az általunk felvázolt modellek között. Ezek fôleg abból adódnak, hogy míg Koop és Korobilis előrejelzési célra fejlesztette ki a saját PKI-ját, addig jelen tanulmány strukturális kérdések megválaszolását tűzte ki célul. Elôször is, az eredeti cikkben nem számítanak makrogazdasági faktorokat (nincs (1)-es egyenlet), helyette három változót (GDPdeflátort, munkanélküliségi rátát és a GDP növekedési ütemét) teszik be a VAR-ba a faktorok mellé (tehát $y_{t}$ dimenziója náluk három). Ez az eljárás azonban - bár egyszerúbben becsülhetôvé válna a modell - az általunk használt 34 makrováltozóhoz képest jelentôsen leszúkítené a változók számát. Másodszor, Koop és Korobilis több modellt is megbecsült, amlyek abban különböznek egymástól, hogy a pénzügyi változók mely halmazából számolnak PKI-t. Ezután a jól teljesítô modelleket előrejelzési képesség alapján súlyozták össze, ráadásul időben változó módon, így náluk az is változott, hogy hány változóból készült a PKI.

A harmadik, említésre méltó különbség a faktorok számából fakad. Koop és Korobilis egy faktort számít a pénzügyi idôsorokból, ahogy ez a PKI irodalomban megszokott. Elvileg azonban felmerülhet a kérdés, hogy egy faktorral valóban megragadtunk-e minden lényeges információt. Főkomponens-elemzés és időben állandó dinamikus faktorok esetén létezik ezen kérdés eldöntésére teszt, a leggyakrabban alkalmazott ezek közül a Bai és Ng (2002) és a Bai és Ng (2007) cikkekben bemutatott tesztek. Mivel az általunk alkalmazott modellre nem találtunk használható tesztet, ugyanakkor ezt a kérdést is vizsgálni szerettük volna, idôben állandó paraméterú modellekkel is számítottunk faktorokat (ráadásul jelen esetben nem 
A magyar bankrendszer makroprudenciális szempontból

csak a banki adatok esetén, hanem a makroidősoroknál is kérdéses, hogy hány faktorra van szükségünk). Ezekre az említett tesztek egy és hat közé javasolták a faktorok optimális számát. Végül - a késôbb bemutatandó impulzusválaszok szignifikanciáját is figyelembe véve - a banki adatbázis esetén kettő, míg a makro idôsorok esetén négy faktor használata mellett döntöttünk.

\subsubsection{A modell becslése}

A becslési eljárások teljeskörú bemutatását tartalmazza Doz et al. (2011), valamint Koop és Korobilis (2014) $\left.\right|^{5}$ Az elsô említett cikk dinamikus faktorok számításához mutat be egy kétlépcsôs becslési eljárást. Ennek elsô lépésében OLS-becsléssel határozza meg a modell paramétereit fôkkomponensek alapján, majd a második lépésben Kálmán-szûrôvel számítja ki a faktorokat. Becslésünk során elsôként a makrofaktorokat ezzel a módszerrel határozzuk meg.

Utóbbi cikk ennek az eljárásnak az időben változó paraméterekre általánosított formája. Idôben változó paraméterú modellek becsléséhez a legújabb eljárások általában bayesi módszereket használnak, amelyek Markov Chain Monte Carlo szimulációt igényelnek (ilyen modellre példa: Del Negro és Otrok (2008), Moench et al. (2013)). Ez a modellek számítási igényét nagy mértékben megnöveli. Az itt használt eljárásnak ezekkel szemben előnye, hogy a futási ideje lényegesen rövidebb. Múködési elve a következő: ugyanúgy fookomponens-elemzésbôl indul ki, mint a Doz et al. (2011) cikk, azonban egy duális Kálmán-szưrô/simító eljárás következik ezután (mivel egy klasszikus Kálmán-szúrôvel nem lehetne egyszerre kiszámítani a változó paramétereket és a faktorokat is). Elôször a foókomponens (és a kezdőértékek függvényében) újrabecsli a paramétereket, majd a második lépésben a paraméterekból újraszámítja a faktorokat.

\footnotetext{
${ }^{4}$ Robusztusságvizsgálatként elvégeztük a modellbecslést egy banki, illetve három és öt makrofaktorral is. Ezek nem módosították érdemben a hitelkínálati sokkok hatásait, a robusztusságvizsgálat eredményeit a sokkok hatásainak tárgyalásánál mutatjuk be.

${ }^{5} \mathrm{~A}$ modell becslése MATLAB program segítségével történt, Dimitris Korobilis kódjainak a felhasználásával, melyek interneten elérhetốk: https://sites.google.com/site/dimitriskorobilis/matlab/forecasting-tvp-favar.
} 
2. fejezet. Hitelkínálati sokkok hatása és egy új pénzügyi kondíciós index egy FAVAR modell alapján

A becslési eljáráshoz még azt kell megadni, hogy a kovarianciamátrixok számítása hogyan történik. Ezekhez sincs szükség szimulációkra, kétfajta varianciamátrix diszkontálási eljárást használtunk (követve Koop és Korobilis megoldását): az exponenciális súlyozású mozgó átlagolást (EWMA) $V_{t}$ és $Q_{t}$, valamint a forgetting faktor eljárást $W_{t}$ és $R_{t}$ kiszámításához (ezekrôl részletes leírást tartalmaz: Koop és Korobilis (2013)). Az EWMA eljárás integrált GARCH modell közelítô eljárásának tekinthetô, a becsült mátrixok az adatokon kívül az elôre megadott, úgynevezett decay faktoroktól függnek. A decay és a forgetting faktorok értelmezése nagyon hasonló: ezek 0 és 1 közé esô számok, minél kisebb az értékük, a kovarianciamátrix adott időpontbeli értéke annál inkább csak abban a negyedévben megfigyelt adatoktól függ. Minél távolabbi adatokat veszünk ettől az időponttól, annál kevésbé játszik szerepet a megfigyelés a becsült mátrix értékében. Amennyiben ezek 1-gyel egyenlők, a modell paraméterei konstansok lesznek. Értékük szakértői alapon és a modell teljesítménye alapján határozható meg.

A becslés lépései tehát a következők:

1. Makrofaktorok megbecslése

(a) Főkomponensek kiszámítása

(b) Kálmán-szürô/simító

2. Kezdőértékek megadása

(a) A paraméterekre és a pénzügyi faktorokra: $\lambda_{0}^{x}, \beta_{0}, f_{0}^{x}, V_{0}, Q_{0}$

(b) Fókomponensek kiszámítása a a pénzügyi adatokból

3. A duális Kálmán-szûrô elsô lépése: paraméterek megbecslése a főkomponensek mellett

(a) A kovarianciamátrixok $\left(V_{t}, Q_{t}, R_{t}, W_{t}\right)$ becslése EWMA és forgetting faktor eljárásokkal

(b) $\lambda_{t}^{x}, \beta_{t}$ becslése Kálmán-szûrôvel/simítóval

4. A duális Kálmán-szûrô második lépése: pénzügyi faktorok újrabecslése az előzô pontban kiszámított paraméterek mellett 
Az eredmények bemutatása előtt még a kezdőértékek megadásáról kell szót ejtenünk. Ezeknél arra törekedtünk, hogy minél inkább összhangban legyenek a kezdőértékek az adatokból nyert információval (tehát, hogy az eredményekben a változást ténylegesen a megfigyelésekből leszûrhető összefüggések változása okozza, és ne a rossz kiindulási értékek utáni konvergencia). Így a következôket választottuk: $\lambda_{0}^{x} \sim N(0,1), \beta_{0} \sim N\left(0, V_{\min }\right)$, ahol $V_{\min }$ egy diagonális kovarianciamátrix, az átlójában lévô értékek $0.1 / r^{2}$-tel egyenlók ( $r$ azt jelöli, hányadik késleltetéshez tartozik az adott együttható, ez egy Minnesota-priorhoz hasonló feltételezés). $f_{0} \sim N(0,1), V_{0}$ és $Q_{0}$ diagonális mátrixok, elóbbinek 0.1, utóbbinak 0.01 szerepel az átlójában. A kezdőértékek hatásának kiszürésére az eredmények értékelését mindig a 11. idôszaktól (2004Q4-től) kezdődően végezzük.

Végül, a forgetting és decay faktorok megadása van még hátra, a 2.1 tes táblázat mutatja Koop és Korobilis, valamint a mi választásunkat. $\kappa_{3}$ és $\kappa_{4}$ határozza meg, hogy a loadingok és a VAR-együtthatók mennyire gyorsan változhatnak. Ezekrôl az idóben változó VAR (Cogley és Sargent (2005)) és FAVAR irodalom is azt feltételezi, hogy nagyon lassan módosulnak. Koop és Korobilis azt találta, hogy a modellek előrejelzô-képessége drasztikusan romlik, ha 0.99-nél kisebb értékeket adnak meg ezekre a faktorokra. Mivel az említett becslések az USA adataira készültek, és Magyarországon a felzárkózás, a pénzügyi mélyülés és az utóbbi évek szabályozói változásai nagyobb változást indokolnak a paraméterekben, mi ennél némileg kisebb értéket választottunk. Ugyanakkor azt is tapasztaltuk, hogy az eredmények szignifikanciáját csökkenti $\kappa_{3}$ és $\kappa_{4}$ további csökkentése, ezért viszonylag magas értékeket állapítottunk meg.

$\kappa_{1}$ és $\kappa_{2}$ értékei azt határozzák meg, hogy mennyire heteroszkedasztikusak a VAR-hibatagok és a (2)-es egyenlet hibatagjai. Koop és Korobilis azt találta, hogy $\kappa_{1}$ és $\kappa_{2}$ kisebb értékei nem rontanak jelentôsen a modellek előrejelzési teljesítményén, ami alátámasztja a heteroszkedasztikus hibatagok feltételezését (még 0.96-nál kisebb érték választása esetén sem). $\kappa_{1}$-nél mi is ezt tapasztaltuk, azonban a VAR hibatagok kovarianciamátrixánál lassabb változást tettünk csak lehetôvé. Ennek oka az adatok megválasztásának különbözôsége: ốk pénzpiaci adatokból számítottak pénzügyi faktorokat és makrogazdasági idôsorokat tartalmazott még a VARbecslésük. Ezzel szemben mi banki idôsorokból készítettünk pénzügyi faktorokat 
2. fejezet. Hitelkínálati sokkok hatása és egy új pénzügyi kondíciós index egy FAVAR modell alapján

és makrofaktorokat tartalmazott még a VAR-modellünk. Utóbbiak valószínúleg kevésbé heteroszkedasztikusak, mint az előbbiek.

2.1. táblázat: Decay és forgetting faktorok

\begin{tabular}{|l|c|c|c|c|}
\hline & $\kappa_{1}\left(V_{t}\right)$ & $\kappa_{2}\left(Q_{t}\right)$ & $\kappa_{3}\left(W_{t}\right)$ & $\kappa_{4}\left(R_{t}\right)$ \\
\hline Koop és Korobilis & 0,96 & 0,96 & 0,99 & 0,99 \\
\hline Hosszú & 0,96 & 0,98 & 0,98 & 0,98 \\
\hline
\end{tabular}

\subsection{Eredmények}

\subsubsection{Faktorok}

Az eredmények bemutatását a faktorokkal kezdjük (a két banki faktor az 2.1 -es ábrán látható). Ahogy már említettük, a banki adatokból két faktort becsültünk, ebben a két változóban az eredeti adatok varianciájának közel 50 százalékát sikerült megjeleníteni. Az időben változó paraméterủ becslésünk eredményeit összehasonlítottuk két másik faktorelemzési eljárással: főkomponens-elemzéssel és a Doz et al. (2011) tanulmányban olvasható dinamikus faktorokkal is. Általánosan elmondható, hogy a három módszerból kapott faktorok nagyon hasonló képet mutatnak. Az idôben változó modellból kapott faktorok kevésbé volatilisek, mint a másik két becslés idôsorai (különösen igaz ez a főkomponens-elemzésre), egyedi/kiugró események kisebb ugrásokat eredményeznek bennük.

A különbözô modellekból kapott nagyon hasonló faktorok kapcsán felmerülhet a kérdés, hogy egyáltalán szükség van-e idôben változó paraméterú becslésre. Először is meg kell jegyeznünk, hogy a decay és forgetting faktorok magas értéke biztosítja, hogy a faktorbecslés paraméterei idôben ne változzanak túl gyorsan (ellenkezô esetben a modell hajlamosabb lenne a túlilleszkedésre), így nagyon eltérô eredményeket nem is kaphatunk az időben változatlan modellekhez képest. Ugyanakkor a pénzügyi sokkok várható nagysága és impulzusválaszai bizonyos esetekben jelen- 
tôsen eltérnek a minta különböző időszakaiban, így az idôben változó paraméterú becslés indokolt.

A fókomponensek közötti korreláció definíció szerint nulla, a faktorok esetében azonban már nincs ilyen kikötés. Ennek ellenére modelljeinkben a faktorok közötti korreláció nagyon alacsony: a Doz et al. (2011)-féle faktorok esetén 0,0004, míg az időben változó faktorok között 0,0049 .

\section{1. ábra: Pénzügyi faktorok}

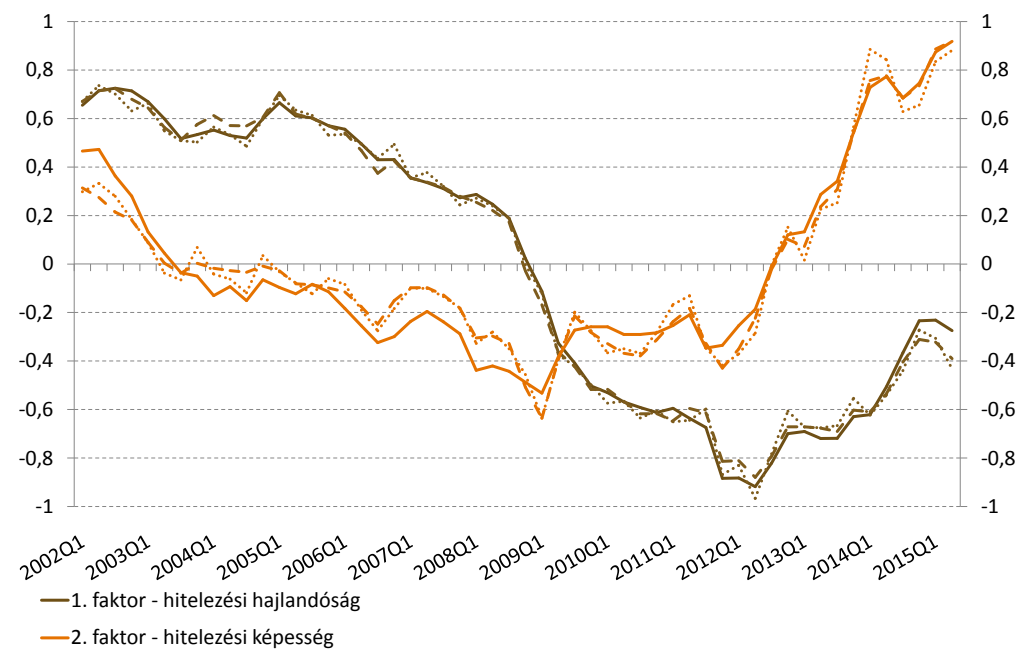

Megjegyzés: a folytonos vonalak az idôben változó paraméterü faktorokat, a szaggatott vonalak a Doz et al. (2011) módszerrel becsült faktorokat, a pöttyözött vonalak a fókomponenseket jelölik.

Megvizsgáltuk azt is, az eredeti változók közül melyekkel mozognak együtt szorosabban a kapott faktorok, és ebből fakadóan hogyan lehetne értelmezni óket. A kérdés eldöntéséhez minden banki változó sztenderdizált változatára futtattunk egy regressziót, amelyben a faktorok szolgáltak magyarázóváltozóként. 6 Ezek eredményeit mutatja a 2.2 es táblázat, amelyben a regressziók $R^{2}$ értékei és a faktorok becsült együtthatói szerepelnek a mintában szereplő tíz bankra átlagolva. Az

\footnotetext{
${ }^{6}$ Használhattuk volna ehhez a faktorloadingokat is, ezek egész idôszakra vett átlaga közel megegyezố eredményt ad a regressziós együtthatókkal.
} 
2. fejezet. Hitelkínálati sokkok hatása és egy új pénzügyi kondíciós index egy FAVAR modell alapján

2.2. táblázat: A pénzügyi faktorokra és az eredeti változókra futtatott regressziók eredményei

\begin{tabular}{|l|c|c|c|}
\hline Változó & $\mathbf{R}^{\mathbf{2}}$ & $\mathbf{1 .}$ faktor & $\mathbf{2 .}$ faktor \\
\hline Likvid eszközök* $^{*}$ & 0,57 & $\mathbf{- 0 , 5 0}$ & $\mathbf{0 , 3 5}$ \\
\hline Stabil források* & 0,68 & $-0,19$ & $-0,14$ \\
\hline Deviza swapok* & 0,33 & $-0,27$ & $-0,22$ \\
\hline Anyabanki tókeáttétel*** & 0,63 & $\mathbf{0 , 5 5}$ & $-0,27$ \\
\hline Tókepuffer* & 0,32 & $-0,19$ & 0,16 \\
\hline Tókeáttétel*** & 0,42 & 0,25 & $\mathbf{- 0 , 4 0}$ \\
\hline NPL-ráta változása & 0,16 & $-0,25$ & $-0,25$ \\
\hline Értékvesztés eredményrontó hatása** & 0,59 & $\mathbf{- 0 , 7 3}$ & $-0,01$ \\
\hline Kockázattal súlyozott eszközök* & 0,33 & $-0,20$ & $\mathbf{0 , 3 4}$ \\
\hline Kamat- és jutalékjövedelem* & 0,49 & $\mathbf{0 , 4 3}$ & $\mathbf{0 , 3 0}$ \\
\hline
\end{tabular}

Megjegyzés: * mérlegfóösszeg arányában, ** hitelek arányában, *** tôkeáttétel: mérlegfőösszeg az összes tóke arányában

együtthatókból faktoronként az abszolút értékben legnagyobb négy értéket kiemeltük, ezek a változók határozzák meg legjobban a faktorok alakulását.

Eszerint az elsố faktor értéke magas, ha alacsony a meglévô hitelállomány hitelezési kockázata, magas az eszközarányos kamat- és jutalékjövedelem, az anyabank magas tőkeáttétellel múködik és alacsony a likvid eszközök aránya. Az elsô két mutató (hitelezési kockázatok) alacsony szintje mellett a bankoknak lehetôsége van kockázatosabb hitelezési szegmensek felé elmozdulni, míg az utóbbi két mutató magasabb szintje arra utaló jel, hogy a bankok nagyobb hitelezési volument és magasabb kockázatokat hajlandók vállalni. Ezért ezt a faktort hitelezési hajlandóságként azonosítottuk. A második faktor szintje nô, ha nő a likvid eszközök aránya és a bankok eszközarányos kamat- és jutalékjövedelme, valamint csökken a tôkeáttétele. Tehát ez a faktor akkor magasabb, ha a bankok likviditási és tôkehelyzete stabilabb, nyereségessége nagyobb. Ezért ez a faktor a hitelezési képesség mérésére lehet alkalmas. Még érdemes kiemelni azt az eredményt, hogy az elsô faktor esetében az anyabanki tókeáttétel sokkal jobban együttmozog a faktorral, 
mint a bankok saját tókeáttátele (elóbbinél az együttható 0.55 , utóbbinál 0.25 ). Ez egybecseng azon korábbi hipotézisünkkel, miszerint a külföldi tualjdonban lévô bankoknál az anyabank tókehelyzete informatívabb lehet a hitelkínálatot illetôen, mint a leánybanké. Meg kell jegyeznünk, hogy a faktorok értelmezésének ez a módja csak részben tekinthetô módszertanilag alátámasztottnak. Ugyanakkor - ahogy majd a következô alfejezetekben bemutatjuk - az impulzusválaszok elemzése során is hasonló következtetésre juthatunk a két faktor okozta sokkok makrogazdasági következményei alapján, és a faktorok idôbeli alakulása is egybeesik a hitelezési hajlandóságról és képességrôl alkotott szakértôi képpel.

Elméleti szempontból egy lehetséges interpretációja a hitelezési képességnek és hajlandóságnak a következô: a bankok minden idôpontban egy optimalizációs feladatot oldanak meg korlátok mellett. A likviditási és szolvencia-előírások szolgálnak korlátokként, melyek meghatározzák a bankok számára az elérhetô lehetôségek halmazát. A hitelezési képesség azt mutatja, a bankok választása mennyire esik közel a szabályozói korlátokhoz, minél nagyobb a faktor értéke a bankok rendszerszinten annál távolabbi kimenetet választanak a szabályozói előírásokhoz képest. Ezért minél kisebb a faktor értéke, annál valószínúbb, hogy a hitelezési képesség szignifikáns hatást gyakorol a makrogazdaságra. Másik oldalról, a hitelezési hajlandóság azt mutatja, hogyan változtatják a bankok a döntésüket a lehetséges kimenetek halmazán belül. Ezek a változtatások - egyebek mellett például - profitmaximalizálási szempontokkal vagy a kockázati étvágy változásával magyarázhatók. Ha egy bank például magasabb hitelezési veszteségeket szenved el, mint amire számított, a nemteljesítô hitelállománya megnô, a profitabilitása csökken. Ebból kifolyólag várhatóan az új hitelek esetén kevesebb kockázatot hajlandó vállalni a korábbiakhoz képest.

Az elsô faktor idősora alapján a hitelezési hajlandóság 2005-ig körülbelül konstans, magas szinten állt köszönhetôen az anyabanki kockázatvállalási kedvnek és az alacsony hitelezési veszteségeknek. Majd lassan elkezdett csökkeni 2008-ig, amikor a válság hatására jelentôs esést mutatott és negatív tartományba került, párhuzamosan a devizahitelekból származó veszteségek realizálódásával és a források beszúküulésével. 2009-tôl (a kedvezményes végtörlesztés által érintett negyedéveket leszámítva) körülbelül azonos, meglehetôsen alacsony szinten maradt, majd 
2. fejezet. Hitelkínálati sokkok hatása és egy új pénzügyi kondíciós index egy FAVAR modell alapján

2013-ban lassan elkezdett növekedni, ez a folyamat azonban 2015-ben megtorpant. A hitelezési képesség faktora a minta elején érte el legmagasabb szintjét, majd a devizahitelezés felfutásával párhuzamosan a bankok tóke és likviditási helyzete egyre kifeszítettebbé vált, ami a hitelezési képesség folyamatos gyengülésével járt együtt. A válság után bekövetkezett anyabanki tôkeemelések és likviditásjavító intézkedések 2009-re jelentôsen növelték az intézmények hitelezési képességét, ami az óvatos banki viselkedésnek és a visszafogott hitelezési aktivitásnak köszönhetôen már 2011-re pozitív tartományba került és azóta is folyamatos emelkedést mutat, az utolsó idôpontban historikus csúcsot ért el.

Ahogy már korábban említettük, végeztünk robusztusságvizsgálatot a faktorok számát illetôen. A pénzügyi faktorok erre vonatkozólag erôsen robusztusnak bizonyultak (az eredményeket a Függelék 5.4 es ábrája mutatja).

\section{2. ábra: Makrogazdasági faktorok}

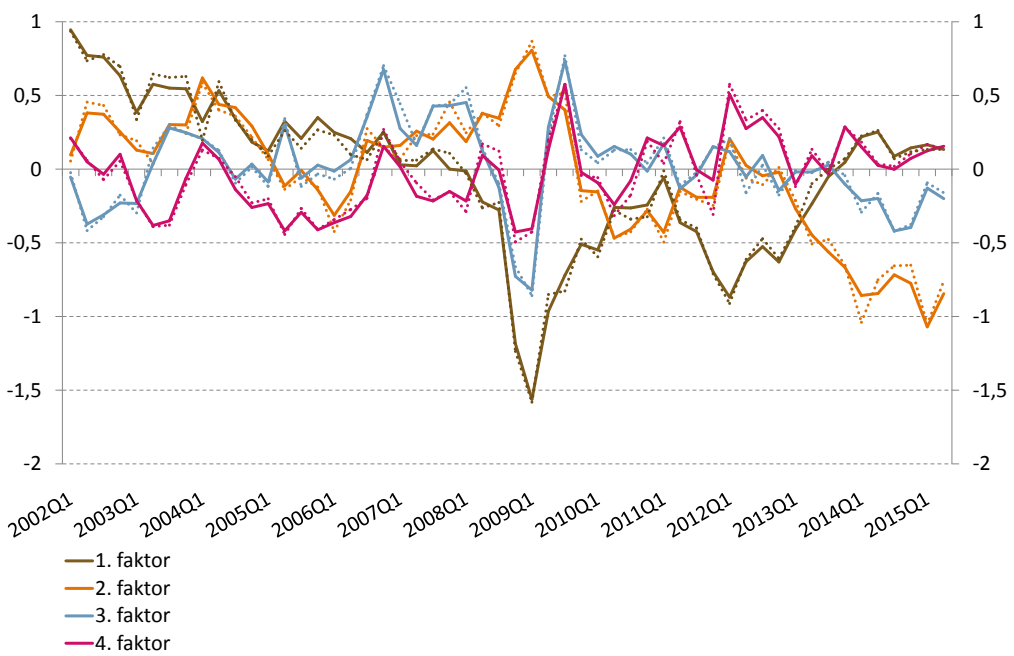

Megjegyzés: a folytonos vonalak a Doz et al. (2011) módszerrel becsült, a pöttyözött vonalak a fókomponenseket jelölik.

A makroökonómai változókból négy faktort képeztünk (ezek láthatók a 2.2 es ábrán), a statikus főkomponens-elemzéssel és Doz et al. (2011) dinamikus becs- 
lésével ismét nagyon hasonló eredményekhez jutottunk. Ezúttal a változók varianciájának 65 százalékát sikerült megragadni a faktorokkal, a banki változókhoz hasonló regressziókat végeztünk ebben az esetben is, az így kapott $R^{2}$-ek a Függelékben megtalálhatók.7 Ezeknél a faktoroknál azonban nem próbálunk értelmezést keresni, egyrészt, mivel ez 4 faktornál és 34 változónál nehézkes is lenne, másrészt a további eredmények értékeléséhez erre nem lesz szükségünk.

\subsubsection{Pénzügyi faktorok}

A faktorok megismerése után rátérhetünk a faktorokkal becsült VAR-modell és az impulzusválaszok elemzésére. A VAR-modellben két késleltetést használtunk és Cholesky-dekompozícióval számoltuk ki az impulzusválaszokat. Mivel ezt az eljárást választottuk, tisztázni kell, milyen sorrendet feltételeztünk a sokkdekompozíciónál és erre mennyire érzékeny a modell. Első helyen a 4 makrofaktor szerepel, utána következik a 2 pénzügyi faktor. A faktorok becsléséból fakadóan egy-egy blokkon (makro, illetve pénzügyi) belül a faktorok és így a hibatagok is közel ortogonálisak, ezért sorrendjükre a modell eredményei teljesen robusztusak. Az olyan tanulmányokban pedig, ahol pénzügyi faktorokat is tartalmazó VAR-t Choleskydekompozícióval vizsgálnak, az a megszokott eljárás, hogy a faktor a makrováltozók után következik, így mi is ezt alkalmaztuk.

Kérdésként merül fel, hogy mekkora sokk hatását számszerúsítsük, mivel a faktoroknak nincs természetes mértékegysége. Ilyenkor a hibatagok szórásának megfelelô nagyságú sokkal szokás számolni. A mi becslésünkben azonban a hibatagok szórása is változik időben, így, ha ezt az eljárást követnénk, az impulzusválaszok két ok következtében is változhatnának: a sokk mértéke és a sokkra adott válasz változása miatt. Ezt a két hatást azonban szeretnénk különválasztani, mivel mind-

\footnotetext{
${ }^{7}$ Szintén Függelékben megtalálhatók mind a banki, mind a pénzügyi faktorok esetén a 90 százalékos konfidenciaintervallumok is $(5.1,5.2,5.3$ ábra). A faktorok becslése annál bizonytalanabb, minél nagyobb sorszámú faktort becslünk meg, ami látszik a konfidenciasávokon is, különösen a makrofaktoroknál. Ugyanakkor ezek a sávok viszonylag kis becslési bizonytalanságot mutatnak, ami egybecsneg azzal az eredménnyel, hogy más módszerekkel is hasonló faktorokhoz jutottunk.

${ }^{8}$ Ha fókomponensekkel becsülnénk a FAVAR modellt, az Akaike és a Schwartz információs kritériumok is 2 késleltetést tartanak optimálisnak.
} 
2. fejezet. Hitelkínálati sokkok hatása és egy új pénzügyi kondíciós index egy FAVAR modell alapján

két ok érdekes lehet. Az impulzuválaszoknál ezért mindkét faktornál egységnyi sokk hatását fogjuk vizsgálni minden idôpontban. Az egyedi változók impulzusválaszai a makrofaktorok impulzusválaszainak lineáris kombinációiként adódtak, ahol a súlyok szerepét a makrofaktorok loadingjai töltötték be.

2.3. ábra: A pénzügyi faktorok volatilitása

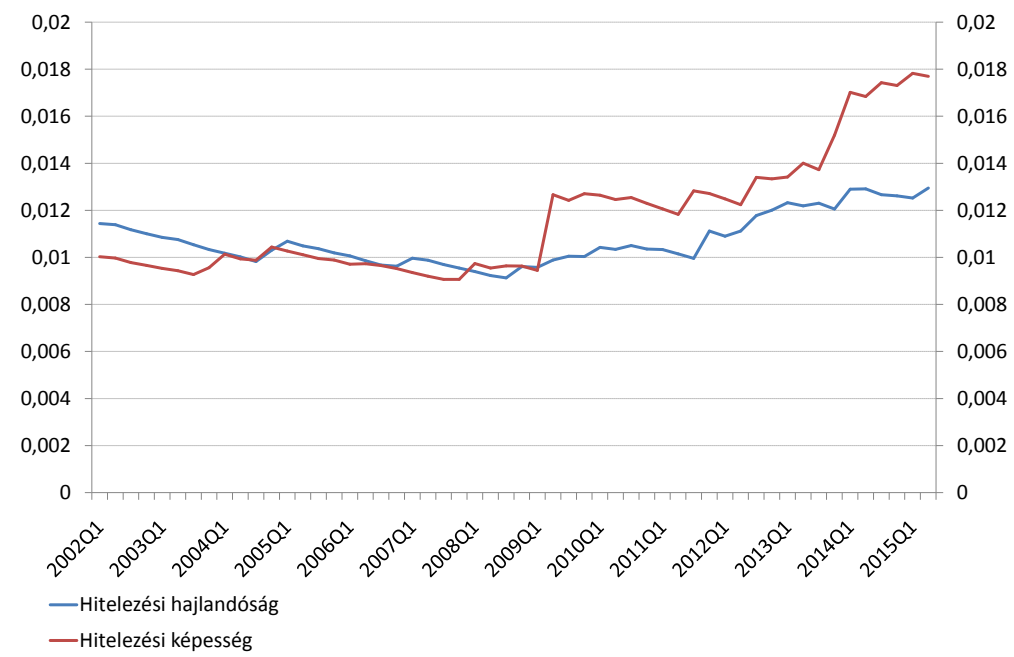

A 2.3 ábra mutatja a banki faktorokhoz tartozó hibatagok szórását, eszerint a válság elôtt nem történt jelentôs változás ebben a mutatóban. A válság utáni idôszak viszont egész más képet mutat: először is, a hitelezési képesség volatilitása megugrik és az utána következő negyedévekben ez a növekedés nem korrigálódik vissza, hanem tovább folytatódik, a válság előtti szinthez képest közel megduplázódik. A hitelezési hajlandóság volatilitása szintén fokozatosan nőtt a 2008 utáni idôszakban, bár csak kisebb mértékben. Tehát ezek alapján a bankrendszeri sokkok mértékének vagy valószínúségének megnövekedése nem egy egyszeri kiugró pont volt a válság kitörésekor, hanem egy tartósabb szinteltolódás. Ez fóként azzal magyarázható, hogy 2008 óta sokkal nagyobb figyelmet kaptak a makroprudenciális szempontok, így számos új tôke és likviditási szabálynak kell megfelelnie a bankoknak. Ennek hatására lényegesen több szabályozói sokk éri a bankrendszert, mint a 2008 előtti idôszakban. Ez jól tükröződik abban is, hogy a hitelezési képesség 
volatilitása nôtt meg nagyobb mértékben - amely szorosabb kapcsolatban van a szabályozói környezettel - a hitelezési hajlandósághoz képest. Érdekes összehasonlítani a makroökonómiai? és a pénzügyi faktorok hibatagjainak szórását is: a makro faktorokban a válság kitörésének évében volt egy nagy ugrás, amely után a szórások vagy nem nôttek tovább, vagy kezdenek visszatérni alacsonyabb szintekre. Ez a különbség is erôsíti a szabályozói környezet hatására vonatkozó megállapításunkat.

\subsubsection{Hitelezési hajlandóság}

Először az 1. faktorra, azaz a hitelezési hajlandósági sokkra adott impulzusválaszokat mutatjuk be, majd a hitelezés képességi (2. faktor) sokkokra végezzük el ugyanezt. ${ }^{10}$ A hitelezési hajlandósági sokkra adott impulzusválaszokról általában elmondhatók, hogy viszonylag keveset változtak a megfigyelt mintán (5.6, 5.7ábra). Egy kisebb hullám figyelhető meg 2004 és 2008 között, ekkora esett a háztartási devizahitelezés, amelynek következtében a háztartási nemteljesítő állomány jelenleg közel 20 százalékos szintet ér el. Ebben az időszakban a bankok nagyon laza hitelezési sztenderdeket alkalmaztak, így hihető, hogy a minta többi időszakához képest erôteljesebb hatása volt ekkor a hajlandóságnak. Még három idôpontban térnek el az impulzusválaszok az átlagosnak mondhatótól: 2008Q4-ben, 2012Q3ban és 2015Q2-ben. Ezek mindegyike egy-egy konkrét eseményhez köthetô: válság kitörése, kedvezményes végtörlesztés, tisztességtelen kamatok elszámolása, amelyek hatása általában két negyedéves késéssel jelentkezik a makrofaktorokban. Általában még elmondható, hogy kevésbé szignifikáns és gyorsabban lecsengố sokkokat kapunk a hitelezési hajlandóság esetén, mint amit látni lehet a hitelezési képesség sokkjainál.

Rátérve a makrogazdasági változók impulzusválaszaira, a következő kép rajzolódik ki: ahogy egy hajlandósági sokktól elvárható, minden hitelállomány növekszik, miközben a hitelkamatok nem változnak szignifikánsan, illetve a lakáshitelek kamatai enyhén csökkennek (5.10 ábra). Azaz, változatlan kamatok mellett hajlandók a bankok nagyobb (kockázatosabb) ügyfélkört hitelezni. Ez az eredmény egybecseng

\footnotetext{
${ }^{9} \mathrm{~A} 2.3$ ábra a Függelékben megtalálható.

${ }^{10} \mathrm{Az}$ impulzusválaszokhoz tartozó ábrák a Függelékbenben találhatók, a konfidenciaintervallumok 10000 futtatás alapján készültek.
} 
2. fejezet. Hitelkínálati sokkok hatása és egy új pénzügyi kondíciós index egy FAVAR modell alapján

Király és Nagy (2008) következtetéseivel: a válság előtt a bankok hitelkínálata és hitelállománya nőtt, egyre kockázatosabb háztartásokat és vállalatokat hiteleztek miközben a kamatok nem csökkentek. A fóbb GDP-tételek, illetve az ipari termelés növekedik a hitelkínálati sokkra, azonban a hitelállományoknál kisebb mértékben és a hatás viszonylag hamar lecseng, így szignifikáns foglalkoztatási hatás nem mutatható ki (5.11 ábra). A foglalkoztatási hatás vélhetően azért is kisebb, mert a vállalatok a hitelból a munkát tôkével helyettesítik, amely jelenséget a beruházás impulzusválasza is alátámaszt. A magasabb GDP-növekedés csökkentôleg hat az országkockázatra, így az államkötvények felára csökken, a magasabb import hatására viszont enyhén leértékelődik az árfolyam. Az árak nem reagálnak szignifikáns mértékben a sokkra, így az alapkamat sem változik, azonban a lakáshitelpiac élénkülésével együtt a lakásárak is növekednek (5.12 ábra). Ahogy a makro faktoroknál, úgy (természetesen) a változók esetében sem látható nagy eltérés az idődimenzió mentén az impulzusválaszokban. Kis mértékben a fogyasztásnál, a GDP-nél és a lakásáraknál tapasztalható, hogy a 2004-es impulzusválasz nagyobb, mint a késôbbiek, ez valószínúleg a devizahitelezés hatásának tudható be.

A szignifikáns impulzusválaszok nagyon hasonló képet mutatnak a fent leírtakhoz akkor is, ha csak egy pénzügyi faktort tartalmaz a modell. A negyedik makrofaktor és a hitelállományok, lakáshitelkamatok, árfolyam és export közötti kapcsolat erôs, ezért, ha a modell csak három makrofaktort tartalmaz, az említett változók impulzusválaszai kisebbek. Egy további makrofaktor szerepeltetése a modellben érdemben nem változtat az eredményeken (lásd: 5.16, 5.17, 5.18 ábrák a Függelékben).

\subsubsection{Hitelezési képesség}

A hitelezési képességi sokkok esetén perzisztensebb impulzusválaszokat kapunk, mint az elôzố esetben. Ahogy már korábban megállapítottuk, a képességi sokkok mértéke megnôtt a válság után, az impulzusválaszok alapján az is elmondható, hogy hatásuk is megnôtt. Az elsố és a negyedik makro faktorra gyakorolt hatás már 2004 óta elkezdett növekedni és az utóbbi években magasabb szinten maradt. A második makro faktor impulzusválaszában pedig inkább a válság után történt 
eltolódás. Ráadásul ezek a változások nem egy-egy eseményhez köthetők, hanem trendszerúen, több év alatt következtek be (5.8, 5.9 ábra).

A hitelezési képességi sokk hatása meglehetôsen eltérô a hajlandósági sokkétól. Azzal, hogy javul a bankrendszer hitelezési képessége, vagyis tóke- és likviditási helyzete, erôsödik a pénzügyi stabilitás, ami jelentôsen csökkenti az országkockázatot is. Ez tükröződik az államkötvények felárának nagy mértékú és tartós csökenésében 5.15 ábra). Ha a bankrendszer stabilabb, csökken a bankcsődök miatti állami beavatkozás valószínúsége és várható költsége, amely az országkockázatot is csökkenti.11 Erre reagálva (valamint a változatlan árfolyamra) a monetáris politika is lazít, amit a vállalati kamatok csökenése követ. A háztartási kamatok ezzel szemben nem változnak szignifikánsan (a fogyasztási hitelek enyhén nőnek), ami annak tudható be, hogy a megfigyelt időszakban a hitelállomány döntő töbsége devizában denominált vagy állami kamattámogatásos hitel volt, amelyek kamata nem volt az alapkamathoz (sem más piaci referencia kamathoz) kötve (5.13 ábra). A csökkenố vállalati kamatok hatására a vállalatok olcsóbban jutnak forráshoz, ami csökkentôleg hat az árakra is, valamint növeli a GDP-t, különösen a belsô tételeket (fogyasztás, beruházás). A GDP-vel párhuzamosan a foglalkoztatás is nô, míg a növekvố rendelkezésre álló jövedelmeknek köszönhetően a lakásárak is szignifikánsan nônek 5.14 ábra). Végül, mindez úgy megy végbe, hogy a hitelállományok nem növekednek szignifikánsan.

Ez utóbbi eredmény elsőre kontraintuitívnak túnhet. Ugyanakkor ismét hivatkoznunk kell a a magyar bankrendszer azon tulajdonságára, hogy döntô része külföldi anyabankok tulajdonában van, így a magyar leánybankok tôkehelyzete nem feltétlenül informatív. Ez az eredmény is azt mutatja, hogy a hitelállományok alakulása szempontjából a hitelezési hajlandóság a meghatározó, a hitelezési képesség jelentette korlátok nem effektívek, mivel az anyabankok méretükbôl fakadóan könnyen orvosolni tudják ezeket. Ezt jól mutatja, hogy számos bank tôke szempontjából teljesen kifeszített állapotban volt a válság előtt, a devizahitele-

\footnotetext{
${ }^{11} \mathrm{Ez}$ a jelenség az Eurozóna szuverén válsága idején a magas államadóssággal és rossz kockázati besorolással rendelkezô országoknál volt elsôsorban megfigyelhető (Görögország, Spanyolország, Olaszország, Portugália, Írország), ezekben az években a magyar gazdaságot is nagy sérülékenység jellemezte.
} 
2. fejezet. Hitelkínálati sokkok hatása és egy új pénzügyi kondíciós index egy FAVAR modell alapján

zés időszakában, ugyanakkor folyamatosan bôvítették hitelállományukat. Meg kell említenünk, hogy a Cholesky-dekompozíció használata azt eredményezhette, hogy nem sikerült tökéletesen szétválasztanunk a hitelezési képességi és a kockázati prémium sokkot. Ebben az esetben a hitelezési képességi sokk valójában keveréke egy képességi és egy kockázati prémium sokknak, így a valós impulzusválaszok az általunk becsültnél kisebbek lehetnek.

Fontos látni azonban, hogy - bár a hitelképességi sokk nem hat szignifikánsan a hitelállományokra - jelentôs és növekvố mértékú hatást gyakorol a makrogazdaságra, méghozzá az országkockázat és a monetáris politika reakcióján keresztül. Ugyan a bankrendszer kisebb része van hazai tulajdonban, a költségvetésnek mégis magas terhet jelentene a nagyobb magyar tulajdonú bankok csődje és kimentése. Ezért az országkockázat megítélésében, és így az államkötvény-felárak alakulásában jelentôs szerepe van a bankrendszer stabilitásának. Ráadásul a pénzügyi mélyüléssel, a pénzügyi közvetítôrendszer makrogazdasághoz viszonyított arányának növekedésével ez a hatás egyre erősebb. Ez tükröződik az államkötvényfelárak impulzusválaszain, amely azt mutatja, hogy 2004-hez képest a késóbbi években jobban reagáltak a felárak a hitelezési képességi sokkokra. Ez a növekedés még a válság kitörése előtt következett be, és utána nem folytatódott tovább. A bankközi kamatok alakulása alapján az is elmondható, hogy a monetáris politika reakciója is megváltozott a vizsgált időszakban: itt azonban a válság után tapasztalható eltolódás. Vélhetôen 2008 után az országkockázat alakulása és a pénzügyi stabilitás jelentôsebb szempont lett a monetáris politikai döntéshozóknál, mint a korábbi években. A hitelezési képesség sokkjának növekvô hatása ennek megfelelően jelentkezik a vállalati kamatokban, a GDP-tételekben, a foglalkoztatásban, az inflációban és a lakásárakban is.

A szingnifikáns impulzusválaszok nagyon hasonlóak abban az esetben, ha a modell csak három makrofaktort tartalmaz, az egyetlen kivétel az árfolyam, ami inszignifikánssá válik. Öt makrofaktorral a GDP-tételek, a lakásárak és az államkötvényfelárak impulzusválaszai némileg nagyobbak (a Függelékben a 5.19, 5.20. 5.21 ábrákon láthatók az eredmények). Az impulzusválaszok időbeli változásából a faktorok számától függetlenül ugyanazok a következtetések vonhatók le. 
Az impulzusválaszokból kapott eredményeink bizonyos mértékben összevethetôk korábbi kutatások állításaival. Tamási és Világi (2011) a magyar vállalati hitelpiacon vizsgálta kínálati sokkok hatását egy bayesi SVAR-modell keretében. Két típusú hitelkínálati sokkot identifikáltak: kockázatérzékelési és kamatfelár sokkot. Az itt bemutatptt modell esetén nem csak a vállalati hitelpiacra szúkítettük a becslést és a sokkidentifikáció is más eszközzel történt. Ugyanakkor a hitelezési hajlandósági sokk szintén egy hitelkínálati sokk, amely a hitelállományok változásán keresztül hat a GDP-re, ráadásul idóben stabilnak bizonyultak az impulzusválaszok. A Tamási és Világi (2011) tanulmányban mindkét hitelkínálati sokk növeli a hitelállományt és a GDP-t, erôsíti az árfolyamot, és nem befolyásolja az infláció alakulását. A hitelezési hajlandósági sokk esetén - az árfolyam kivételével mi is ugyanezekre az eredményekre jutottunk. Kockázatérzékelési sokk esetén a kamatfelárak változatlanok maradnak, míg az alapkamat emelkedik, ugyanakkor kamatfelársokk esetén az alapkamat nem változik. Ez azt jelenti, hogy a vállalati kamatok nem változnak meg hitelkínálati sokk hatására, ami szintén összhangban van az itt bemutatott eredményekról. Tamási és Világi (2011) eredményei szerint egy hitelkínálati sokk okozta 1 százalékos növekedés a vállalati hitelállományban 0.1-0.2 százalékkal növeli a GDP-t. A mi számításaink alapján egy olyan hajlandósági sokk, amely 1 százalékponttal magasabb vállalati hitelállomány-növekedést eredményez, a GDP növekedési ütemét 0.07-0.25 százalékponttal növeli. Így elmondható, a két kutatás eredményeiból hasonló következtetésekre juthatunk.

Habár kizárólag magyar adatokat használtunk a modell megbecsléséhez, eredményeink más országok esetében is érdekesek lehetnek. A pénzügyi válságnak és a makroprudenciális politikai eszközök bevezetésének köszönhetôen a pénzügyi sokkok váható mértéke minden érintett országban növekedhetett, amely máshol is indokolttá teszi az időben változó paraméterú modellek használatát. Az európai országokban a pénzügyi közvetítô rendszeren belül a bankrendszer biztosítja a pénzügyi források döntô részét, így - Magyarországhoz hasonlóan - a banki hitelkínálat a legmeghatározóbb a pénzügyi kondíciók tekintetében. A kelet-európai országokban a bankrendszer nagy része általában külföldi tulajdonban van, és a külföldi anyabankok ugyanazt a stratégiát alkalmazzák, mint a magyar leánybankok esetében. Így ezekben az országokban is az anyabanki adatok, a kockázatvállalási 
2. fejezet. Hitelkínálati sokkok hatása és egy új pénzügyi kondíciós index egy FAVAR modell alapján

hajlandóság és a profitabilitás meghatározóbbak lehetnek a hitelkínálat alakulásában, mint a likviditási ás szolvenciahelyzet.

\subsubsection{Pénzügyi kondíciós index}

A pénzügyi piacok múködésének értékelésére a központi bankok (többek között) pénzügyi kondíciós indexeket számítanak. A fent bemutatott modellból mi is számítottunk PKI-t, amelyet az MNB korábbi PKI-jával hasonlítunk össze. Az MNB PKI-jának számítása 2016-ig Tamási és Világi (2011) SVAR-modellje alapján történt (ebben a cikkben még csak a vállalati hitelekre vonatkozó VAR-modell szerepelt, a PKI-számításához a vállalatihoz hasonló módon becsültek SVAR-modellt a fogyasztási hitelekre is). Így azon PKI-k csoportjába tartozott, amelyek a legfontosabb pénzügyi idôsorokat a makrogazdaságra - elsôsorban a GDP-re - gyakorolt hatásuk alapján súlyozták össze. Ezek az idősorok a vállalati és fogyasztási hitelállomány, valamint a vállalati és fogyasztási hitelkamatfelárak voltak. A súlyokat két hatás összegéből számolták: a pénzügyi idősorok GDP-re gyakorolt késleltetett hatását a VAR-modell GDP-egyenletének együtthatói, a szimultán hatást az identifikált sokkok impulzusválaszai határozták meg. A két SVAR modellból kaptak egy vállalati és egy háztartási (fogyasztási hitelekre szúkítve) részindexet, a kettő összegébôl jött létre a végsô PKI. A mutató a bankrendszer hozzájárulását mutatta a GDP éves növekedési üteméhez.

Az így képzett indexnél egyrészt problémát jelentett, hogy a háztartási szektornál csak a fogyasztási hiteleket vette figyelembe, másrészt egyik negyedévrôl a másikra több esetben jelentős mértékú változást mutatott, miközben a pénzügyi közvetítô rendszer helyzete és viselkedése nem változott érdemi mértékben. Ez vélhetôen abból fakadt, hogy olyan változók súlyozásából jött létre az index, amelyeket a hitelkereslet és -kínálat egyaránt nagy mértékben befolyásol, ezért kevésbé pontos mérôje a kínálati oldalnak. Az itt bemutatásra kerülő mutatónál ezzel szemben arra törekedtünk, hogy szélesebb információs bázisból induljunk ki, és a hitelkínálati oldalra jobban koncentráló változókból álljon össze az adatbázis.

Kézenfekvố volt a faktormodellek használata, már csak azért is, mert a legújabb PKI-k szinte kivétel nélkül faktorelemzésból származnak, az elsô faktort szokás 
2.4. ábra: Pénzügyi kondíciós index index

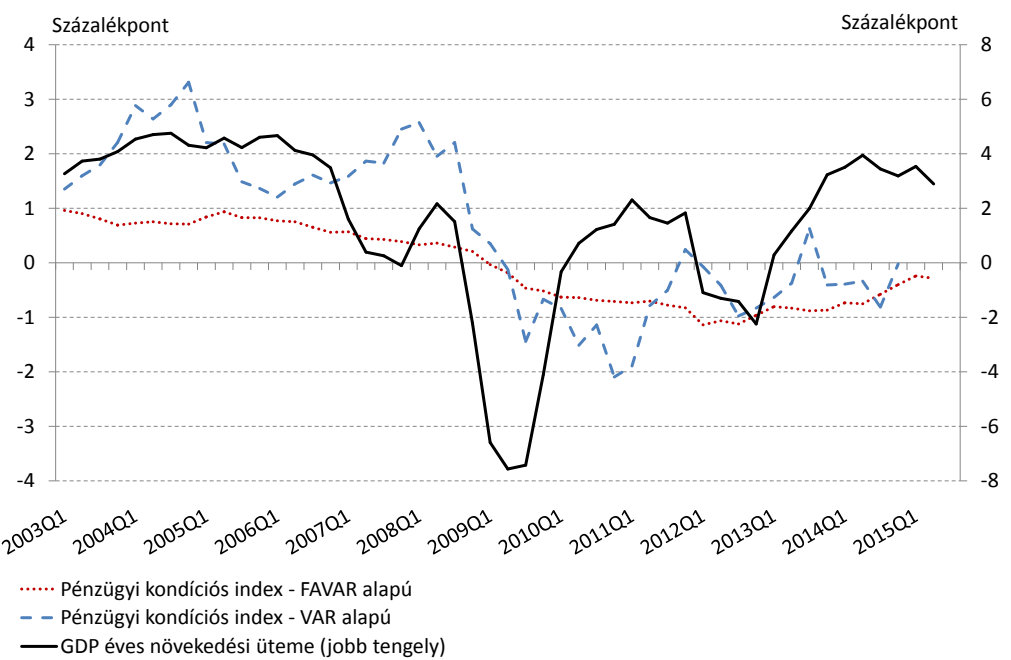

PKI-nak tekinteni. Ugyanakkor e megszokott eljárás ellen szól, hogy a FAVARmodellból azt az eredményt kaptuk, hogy a második faktor is hat a makrogazdaságra, ráadásul a faktorok értelmezése nehézkes, a változásuk hordoz információt, a szintjük nem, ami hátrányt jelentene a korábbi PKI-hoz képest. Ezért egyesítettük a faktormodelleken és a VAR-modelleken alapuló PKI-k előnyeit, és végső mutatóként a hitelezési hajlandóság faktor GDP-re gyakorolt hatását határoztuk meg. A hitelezési képesség hatásától azért tekintettünk el, mert az impulzusválaszok alapján ez a faktor a hitelállományokon keresztül nem fejt ki szignifikáns hatást, a PKI kapcsán pedig az az elvárásunk, hogy a hitelpiacok alakulásáról adjon képet. A GDP-re gyakorolt hatást az idôben változó FAVAR GDP-egyenletének együtthatóiból számítottuk. ${ }^{12}$ Ezzel egy olyan mutatót kaptunk, amelynek megbecslésekor széles információs halmazt használtunk, ugyanakkor egy könnyen interpretálható indikátorhoz jutottunk, melynek mind a szinjte, mind a változása fontos információt hordoz.

\footnotetext{
${ }^{12}$ Változás a korábbi módszertanhoz képest, hogy az impulzusválaszokat nem használtuk fel, ez a különbség az eltérố sokkidentifikációból fakad, mivel a Cholesky-dekompozícióval nem számolunk szimultán hatással.
} 
2. fejezet. Hitelkínálati sokkok hatása és egy új pénzügyi kondíciós index egy FAVAR modell alapján

Az új mutató értelmezése nagyon hasonló a régihez: a bankrendszer hitelezési kínálatának hozzájárulását mutatja a GDP-éves növekedési üteméhez (2.4 ábra). Elôjelét tekintve a két mutató szinte teljesen megegyezik egymással, mértékében az új index kisebb hozzájárulást mutat, és a volatilitása is kisebb mértékú. Indexünk szerint a válság 2008-as kitöréséig a pénzügyi közvetítô rendszer GDP-hez való hozzájárulása folyamatosan pozitív volt: a devizahitelezés felfutásával a GDPhozzájárulás is nôtt, majd 2007-tôl kezdve folyamatosan csökkent. 2009-tôl kezdôdően a bankrendszer hozzájárulása a kibocsátáshoz negatív lett, ez a hatás 2012-ig fokozatosan erősödött. Ekkor az MNB elindította Növekedési Hitel Programját, amelynek célja a banki hitelkínálat növelése volt. 2013-ban és 2014-ben a bankrendszer kontrakciós hatása jelentősen csökkent. Ez a trend azonban 2015 elején megtorpant, és a minta végéig a pénzügyi közvetítőrendszer enyhén negatív hatása fennmaradt.

Az itt bemutatott PKI hasznos döntéstámogató eszközként múködhet monetáris és (különösképpen) makroprudenciális szabályozói szempontból. A PKI nulla értéke azt jelenti, hogy a bankrendszeri hitelkínálat kielégíti a hitelképes vállalatok és háztartások keresletét, a bankrendszer semleges, a hitelkínálat összhangban van a potenciális GDP-vel. Ha a mutató értéke jelentősen meghaladja a nullát, vélhetôen túlzott hitelkiáramlás jellemzi a háztartási és/vagy a vállalati hitelpiacot, azaz az index hitelboomot jelez. Ha a PKI negatív, a hitelkínálat sokkal alacsonyabb a hitelkeresletnél, azaz a hitelezési kondíciók túl szigorúak.

Monetáris politikai szempontból az index a kibocsátási résról adhat információt: a PKI a bankrendszer hitelkínálaton keresztüli hozzájárulását mutatja a kibocsátási réshez, amely segít a pénzügyi közvetítőrendszer üzleti ciklusban betöltött szerepének értékelésében. Makroprudenciális szabályozói szempontból a PKI segíthet beazonosítani a hitelboomok időszakait. A túlzott hitelezés mérésére leggyakrabban használt eszköz a hitelrés, amely azonban nem képes arra a kérdésre válaszolni, hogy a boomot a keresleti vagy a kínálati oldal váltotta ki, így a döntéshozó sem tudja, hogy a piac keresleti vagy kínálati oldalát kell-e szigorúbban szabályozni. Ha a PKI hitelboomot jelez, az a piac kínálati oldalához köthetô, így ebben az estben a bankok hitelkínálatát kell visszafogni. 


\subsection{A fejezet összegzése}

A disszertáció ezen részében egy idôben változó paraméterú FAVAR modell segítségével magyar adatokon két hitelkínálati faktort számítottunk, melyek közül az elsôt hitelezési hajlandóságként, a másodikat hitelezési képességként azonosítottunk. Majd megvizsgáltuk a kétfajta hitelkínálati sokk makrogazdasági változókra gyakorolt hatását, és ezek időbeli változását. Végül becsléseink alapján egy újfajta pénzügyi kondíciós indexet számszerúsítettünk, amely a bankrendszer hitelkínálatának GDP-növekedésre gyakorolt hatását méri.

A számítások elvégzéséhez egy banki paneladatbázist használtunk, amelyben a bankok tôke- és likviditási helyzetét, valamint kockázatvállalási hajlandóságát leíró mutatókat vettünk figyelembe. Az idôsorok összeállításánál arra is tekintettel voltunk, hogy a magyar bankrendszer jelentős része külföldi anyabank tulajdonában van, így hitelkínálat szempontjából az anyabankok tôkehelyzete meghatározóbb lehet, mint a magyar leánybankok mutatói. Ezen feltételezésünket mind a faktorok loadingjai, mind az impulzusválaszokból levonható következtetések alátámasztották.

Modellbecslésünkben a faktorok loadingjai, a VAR-együtthatók, valamint a faktorok és a VAR-egyenletek hibatagjainak szórása is időben változó folyamatként jelent meg. A VAR-hibatagok szórásának változása alapján elmondható, hogy mind a makro, mind a pénzügyi sokkok várható mértéke megnôtt a válság hatására, elóbbieknél azonban ez egy egyszeri megugrás volt, amely azóta kezd visszatérni korábbi szintjére. Utóbbiaknál ezzel szemben továbbra is nô a várható sokkok mértéke, vélhetôen a 2008 utáni, új szabályozói előírások hatására.

A kétfajta hitelezési sokk meglehetôsen eltérô módon hat a makrováltozókra. Legfontosabb ezek közül, hogy egy képességi sokk egy túlnyomórészt külföldi tulajdonban lévô bankrendszerben a GDP-t az országkockázat csökkenésén és a monetáris politikai lazításon keresztül befolyásolja, de érdemi hitelállomány-bôvülést nem okoz, mert a képesség a külföldi tulajdonos miatt rendszerint nem jelent korlátot. A hajlandósági sokk pedig fóleg a hitelezési aktivitást változtatja meg. Ráadásul a képességi sokkok hatása általában perzisztensebb, míg a hajlandósági sokkok gyorsabban lecsengenek. Továbbá, a hitelezési hajlandóságnál kapott impulzusvá- 
2. fejezet. Hitelkínálati sokkok hatása és egy új pénzügyi kondíciós index egy FAVAR modell alapján

laszokból hasonló következtetések vonhatók el, mint Tamási és Világi (2011)-es, hitelkínálati sokkok hatását számszerúsítő tanulmányából.

Idôbeli változás szempontjából is eltér a két pénzügyi sokk egymástól: a hajlandóság hatásának változását a devizahitelezés, valamint egyszeri események (válság kitörése, végtörlesztés, forintosítás) mozgatták, így az eltérések általában rövid időszakokra jellemzőek, és ráadásul kismértékủek a különböző negyedévek között. Ezzel szemben a hitelezési képesség esetén trendszerú folyamatok figyelhetők meg: az országkockázat alakulásában egyre nagyobb szerepet játszott a bankrendszer helyzete a válság előtt, míg 2008 után úgy tûnik, a monetáris politika növekvô mértékben vette figyelembe a pénzügyi stabilitást.

Mindezen eredmények felhasználásával egy új PKI-t készítettünk, amely egyesíti a faktor- és a VAR-modellekból számított indexek előnyeit: széles információs halmazt felhasználva egy könnyen értelmezhetô mutatót ad eredményül. Az index a hitelezési hajlandóság faktor GDP-re gyakorolt hatását mutatja, amelyet a faktorból és a VAR-együtthatókból számítottunk ki. 
A magyar bankrendszer makroprudenciális szempontból 


\section{3. fejezet}

\section{A nemteljesítési valószínûség és az optimális jövedelemarányos törlesztôrészlet-szabály modellezése egy háztartási kérdôíves felmérés felhasználásával}

\subsection{Bevezetô}

A 2007-ben indult pénzügyi válságra a bankszektor jelentős mérlegleépítéssel reagált, miközben a nemteljesító állományok korábban soha nem látott szintekre emelkedtek. 2013-ban a kormányzati intézkedések és a banki törekvések ellenére a nemteljesítő háztartási hitelállományok a teljes állomány már közel ötödét tették ki. Ez a szint a régiós összehasonlításban is rendkívül magasnak tekinthető még akkor is, ha olyan tényezók is emelték, mint a végtörlesztés. Éppen ezért fontos annak feltárása, hogy milyen tényezők játszhattak szerepet e kedvezőtlen folyamat kialakulásában. 
A magyar bankrendszer makroprudenciális szempontból

Kutatásunkban mikro adatok felhasználásával elsődlegesen arra keressük a választ, hogy milyen makro, szoció-demográfiai, illetve hiteljellemzô változókkal magyarázható a nemteljesítés valószínúsége a hazai háztartási jelzáloghitelek esetében. Célunk eléréséhez modellezési eszközül bináris változós ökonometriai becsléseket, elsôsorban logit-modelleket használtunk. Emellett kiemelt feladatunknak tekintettük a jövedelemarányos törlesztési teher (PTI) és a hitelkockázatok kapcsolatát is feltárni. Ennek keretében kísérletet teszünk a PTI azon maximális szintjének meghatározására is, amely mellett még el lehet kerülni az egyes háztartások túlzott eladósodását. Ez utóbbi nem csak a háztartások szempontjából fontos, de pénzügyi stabilitási megfontolásokból is meghatározó lehet. Emiatt kutatásunk nemcsak hiánypótló elemzési célokat szolgál, de kellő alapot jelenthet a szabályozó hatóságok számára a makroprudenciális kockázatok felépülését szolgáló korlátok kidolgozásához.

A hazai lakossági jelzáloghitelezés legfőbb sajátossága a denominációs szerkezete, hiszen a válság kezdetekor a hitelek több mint 70 százaléka külföldi devizában denominált, elsősorban svájci frank hitel volt. A lakossági devizahitelezés kialakulásának okait mind a hazai, mind a külföldi szakirodalomban többen tárgyalták (pl.: Zettelmeyer et al. (2010), vagy Király és Banai (2012)). Basso et al. (2011), akik megállapítják, hogy többek között a könnyú hozzáférés a devizaforrásokhoz, a nagy kamatkülönbözet a hazai és a külföldi devizák között és az ország nyitottsága egyaránt a devizahitelek felé tolja a háztartásokat. Ezek a tényezôk hazánk esetében egytôl-egyig megfigyelhetốk voltak, némiképp magyarázatot adva a kiugró arányú hazai devizahitel-állományra. A válság során a forint árfolyama jelentôsen gyengült a svájci frankkal szemben, így a korábban felépült jelentős lakossági devizahitel-állomány teljesítménye nagy mértékben romlott. A hazai lakossági hitelezéssel foglalkozó tanulmányoknak központi kérdése lett a háztartási hitelek teljesítményét befolyásoló tényezôk.

Hosszú (2011) tanulmányának megállapítása szerint is szerepe volt a háztartások nyitott árfolyampozíciójának a hitelek bedólésénél. A tanulmány a KSH által készített keresztmetszeti mikroadatbázis, a Háztartási Költségvetési Felvétel (HKF) 2004-2008-as idôszakra vonatkozó adatainak felhasználásával elemzi a háztartások fogyasztási és hitelfelvételi döntéseit, valamint ezek jövedelem szerinti he- 
3. fejezet. A nemteljesítési valószínúség és az optimális jövedelemarányos törlesztốrészlet-szabály modellezése egy háztartási kérdőíves felmérés felhasználásával

terogenitását. A háztartások eladósodottsága és munkapiaci helyzete alapján von le következtetést, hogy mely makrogazdasági faktorok játszhatnak fontos szerepet az egyes jövedelmi rétegek nemteljesítôvé válásában. Ezen adatbázis alapján a válság kitörése után az alacsony jövedelmú rétegeknél a jövedelemhez viszonyítottan magas törlesztôrészlet miatt már kismértékú frankárfolyam-erôsödés is hiteltörlesztési problémákhoz vezethetett, míg a középsô jövedelmi rétegeknél elsôsorban a munkahelyvesztés okozhatta a nemteljesítô hitelek arányának emelkedését, amit a forint-svájci frank árfolyam leértékelődése tovább súlyosbított. A HKF-es felmérés legnagyobb hátránya a mostani tanulmányban használt felméréshez képest, hogy a háztartások hiteleirôl lényegesen kevesebb információval szolgál.

Gáspár és Varga (2011) tanulmányukban ugyancsak a HKF mikroadatbázist használták fel a hiteltörlesztési problémák modellezésére. Feltételezésük szerint egy háztartás akkor nem teljesíti a törlesztési kötelezettségét, ha a havi törlesztôrészlete meghaladja nettó jövedelmének 40 százalékát (a megmaradt 60 százalék szükséges az alapvető fogyasztási kiadások fedezéséhez). Az így létrejövő nemteljesítések bekövetkezését három tényezőre vezették vissza: az induló eladósodottsági szint (jövedelemarányos törlesztôrészlet) már túl magas volt, a forint árfolyamának leértékelődése és munkahelyvesztés. Eredményeik szerint a kezdeti törlesztési terhek magas volta a nemteljesítések 50 százalékáért felelôs, 45 százalékot magyaráz az árfolyamváltozás, míg a maradék, igen csekély részért felelős csak a munkanélküliség. A HKF ebben az esetben is hátrányt jelent a hitelekre vonatkozó szúk és nem reprezentatív információs bázis miatt (például a háztartások hitelállománya lényegesen alacsonyabb a HKF adatai alapján, mint a tényleges adósságállomány).

Holló (2009) három (jelentôs háztartási hitelállománnyal rendelkezô) kereskedelmi bank lakossági jelzáloghitel-portfóliójára vonatkozó panel adatbázist felhasználva elemezte a portfólió kockázati jellemzőit. A választott módszertan ebben az esetben a túlélési analízis volt, amely a nemteljesítési valószínúség számításánál figyelembe veszi, hogy a hitel eltérô életciklusaiban eltérô a nemfizetési valószínúsége. Eredményei szerint a hitelek denominációs szerkezete, az induló hitel/hitelfedezeti érték (LTV), az ügyfél iskolai végzettsége tekinthetôk a fóbb nem teljesítések alakulását befolyásoló ügyfél- és termékspecifikus kockázati tényezőknek, míg a munka- 
nélküliségi ráta, a hazai és külföldi kamatok, valamint az árfolyam pedig a fontosabb nem teljesítésre ható makrokockázati faktorok. ${ }^{1}$

Jelenlegi elemzésünk szempontjából fontos Balás (2013) tanulmánya, aki a háztartások eladósodottságának mértékét járja körül makroszintú adatok és a 2010-es HKF felhasználásával. Rávilágít, hogy nemzetközi összehasonlításban a makrogazdasági aggregátumok alapján sem a hitelállomány mértékében, sem a jövedelemarányos törlesztési teherben nem adósodott túl a háztartási szektor. Ugyanakkor a háztartások törlesztési terhei jelentős heterogenitást mutatnak. A legalacsonyabb jövedelmú (alsó kvintilisbe tartozó), hitellel rendelkező háztartások jövedelemarányos törlesztési terhe magas, átlagosan 30 százalék volt 2010-ben. Fontos figyelembe venni, hogy az alacsony jövedelmúek esetében a jövedelem nagyobb része szükséges az alapvető kiadások finanszírozásához. A 30 százalékos jövedelemarányos törlesztési teher esetükben egy lényegesen kifeszítettebb helyzetet jelenthetett, mint a magasabb kvintilisekben. A CHF forinttal szembeni erôsödése pedig jelentôs mértékben tovább ronthatta ezt a helyzetet.

A hazai szakirodalomból végül meg kell említenünk Holló és Papp (2007) tanulmányát is. Bár ez a legrégebbi a felsoroltak közül, így következtetéseiben is ez áll legtávolabb a mostani elemzéstôl, de ez volt az utolsó, mostanihoz hasonló háztartási felmérés az MNB részérôl. A két felmérés érdemben a feltett kérdések köre szempontjából különbözik, mivel ahhoz képest bôvült a feltett kérdések halmaza. Új elemként például a 2013-as kérdőív rákérdezett a háztartás tulajdonában lévô összes ingatlan értékére, nem csak a hitelfedezetként használtakra. Hasonlóan, bekerült a kérdések körébe például az esetleges átstrukturálásra és annak idôpontjára, az árfolyamgátban és a végtörlesztésben való részvételre, illetve hitelközvetítô közremúködésére vonatkozó kérdés. A szerzôk a hitelek nemteljesítési valószínû́ségét modellezik jövedelemtartalék-számítás, logit-modell és neurális háló segítségével. Eredményeik szerint a háztartás rendelkezésre álló jövedelme, a jövedelemarányos törlesztési teher, az eltartottak száma és a családfő munkaerô-piaci

\footnotetext{
${ }^{1} \mathrm{~A}$ kapott modellt végül stressztesztelési célokra használta fel. Ennek továbbfejlesztett változata szolgál jelenleg is az MNB szolvencia-stressztesztje során a háztartási nemteljesítési valószínúségek kiszámítására (az aktuális modell leírása megtalálható Banai et al. (2013)-ban).
} 
3. fejezet. A nemteljesítési valószínúség és az optimális jövedelemarányos törlesztốrészlet-szabály modellezése egy háztartási kérdőíves felmérés felhasználásával

helyzete rendelkezik érdemi magyarázó erôvel. A kapott modelleket a bankrendszer stressztưrő-képességének teszteléséhez használták fel.

A releváns hazai szakirodalom eddigi eredményeit tehát a következôképpen foglalhatjuk össze: Hosszú (2011) és Gáspár és Varga (2011) is három fô tényezốre vezeti vissza a háztartási hitelek nemteljesítését: kezdeti túlzott eladósodásra, munkahelyvesztésre és törlesztôrészlet-változásra. Elôbbi cikk csak arra tér ki, hogy mely jövedelmi rétegeket melyik tényező érintette leginkább, míg utóbbi dekomponálja számszerúen, hogy a nemteljesítôvé válásban melyik ok mekkora szerepet játszott. Mivel az elôbbi cikk szerint a túladósodás az alacsony jövedelmi rétegeknél volt tipikus, utóbbi szerint pedig ez volt a legfontosabb nemteljesítéshez vezető faktor, a nemfizetô háztartásokon belül vélhetően felülreprezentáltak az alacsony jövedelmú háztartások. Ezzel összhangban van Balás (2013) is, amely szerint a háztartások átlagos eladósodottsága nem magas, azonban az átlag jelentôs heterogenitást takar: az alacsony jövedelmú háztartások túladósodtak. Holló és Papp (2007) és Holló (2009) becslései is alátámasztják, hogy mind a három faktor (túladósodás, munkanélküliség és törlesztôrészlet-emelkedés) releváns szerepet játszik a nemteljesítési valószínúség alakulásában: a túladósodást méri (direkt vagy indirekt módon) a hitel/hitelfedezeti érték mutató (LTV), a háztartás rendelkezésre álló jövedelme, a jövedelemarányos törlesztési teher és az eltartottak száma. A munkanélküliség valószínúségét jelzi az ügyfél iskolai végzettsége és a családfó munkaerôpiaci helyzete. Végül, a törlesztőrészlet-változás hatását mérheti (többek között) a hitelek denominációs szerkezete, a hazai és külföldi kamatok, valamint az árfolyam változása. Becsléseink során, ahogy ez a késóbbiekbôl kiderül, mi is hasonló változókör szignifikanciáját állapítottuk meg.

A mostani elemzésünk több dologban is túlmutat az eddigi hazai tanulmányokon. Egyrészt választ ad olyan kérdésekre, mint hogy milyen különbség mutatkozik az egyes terméktípusok között, vagy hogy milyen tulajdonsággal rendelkeznek a különbözô években kibocsátott hitelek. Másrészt szabályozói szempontból is releváns következtetéseket von le a modell alapján.

A külföldi szakirodalomban is nagyon sokat foglalkoztak a háztartási hitelek teljesítményének alakulásával. A válság által nagy mértékben sújtott Spanyolországban például Blanco és Gimeno (2012) tanulmánya is erre fókuszált. A spanyol 
hitelregiszter adatai alapján készített elemzés azt mutatta, hogy a nemteljesítő hitelek alakulását fóként a munkanélküliség, a hitelállomány illetve a szerzốk által létrehozott speciális mutató (ami a törlesztési terheket és a jövedelmi helyzetet is magában foglalja) alakulása határozza meg. A súlyos válságot átélt ír jelzáloghitelpiacot elemzô Lyndon és McCarthy (2013) ugyancsak az intuícióknak megfelelő eredményeket mutatott be. A nemteljesítést leginkább a törlesztô terhek alakulása, illetve az LTV nagysága magyarázta. Emellett a munkapiaci helyzet, illetve a lakásvásárlás célja (befektetés vagy saját használat) is szignifikáns magyarázóerôvel bírt. Az amerikai jelzáloghitel-piaci válságról pedig többek közt Mian és Sufi (2011) értekezett. Azt találták, hogy a csődvalószínúség legnagyobb mértékben azokon a területeken emelkedett, ahol korábban jelentôs volt a lakásárak növekedése, majd zuhanása. Vagyis a fedezetül szolgáló ingatlan értéke nagy mértékben befolyásolja a visszafizetés valószínúségét.

Találunk példát arra is, hogy hasonló lakossági felmérés alapján, ugyancsak bináris változós ökonometriai módszerekkel becsültek csődvalószínüséget. May és Tudela (2005) a brit háztartások jelzáloghiteleinek nemteljesítési valószínúségére becsült egy dinamikus probit modellt, és ezen eredmények alapján határozta meg, hogy melyek azok a tényezôk, amelyek a legnagyobb hatással vannak egy hiteladós bedólésére. Az általuk használt felmérés során minden évben megkérdezik ugyanazon háztartásokat, így lehetôségük volt dinamikusan nézni az egyes tényezốk hatását. A vizsgált változók közül legnagyobb mértékben a munkanélkülivé válás növelte a csôdvalószínúséget, mivel ennél találták a legnagyobb marginális hatást a szerzôk. Emellett nagyon erôteljes hatása volt a kamattörlesztés jövedelemhez viszonyított nagyságának is (a szerzők külön vizsgálták a kamat- és a tôketörlesztést). Végül pedig szintén pozitívan befolyásolta a csődvalószínúséget, ha az adósnak komoly terhei származtak fedezetlen hitelból is. Összességében tehát a törlesztési képességet egyaránt meghatározta a munkapiaci helyzet és a hiteltörlesztés nagysága (ami függ az eladósodottságtól), vagyis a következtetések megegyeztek a hazai irodalomban találtakkal.

Végül LaCava és Simon (2003) is használt a háztartásokra vonatkozó felmérést a hitelek teljesítményét befolyásoló tényezók feltárására. Számunkra kiemelten fontos, hogy az általuk becsült logit modellnél felhasznált minta a miénkhez 
3. fejezet. A nemteljesítési valószínúség és az optimális jövedelemarányos törlesztốrészlet-szabály modellezése egy háztartási kérdőíves felmérés felhasználásával

hasonlóan csak keresztmetszeti információkat tartalmazott. Tanulmányukban nem kizárólag hitelek teljesítményére fókuszáltak, hanem általában a háztartásokat érintô pénzügyi nehézségekre. Arra voltak kíváncsiak, hogy milyen jellemzók növelték annak valószínüségét, hogy egy háztartás pénzügyi nehézségekkel nézett szembe a vizsgálat idején (1998 és 1999 fordulóján). Vizsgálatuk során változók széles köre bizonyult szignifikánsnak. A munkanélküliség, jelzáloghitel törlesztôrészletének nagysága, a hitelkártyákra fizető kamattörlesztés, jövedelem változók mellett olyan egyedi adós jellemzók is szignifikáns magyarázó eróvel bírtak, mint a kor, vagy a háztartás nagysága. Összességében tehát azt látjuk, hogy a nemzetközi szakirodalomban is több helyen használtak bináris változós modelleket a háztartások pénzügyi teljesítményének értékeléséhez. Ezen modelleknél pedig a háztartások jövedelmi pozíciója, a munkapiaci helyzete és az eladósodottság nagysága magyarázta szignifikánsan a háztartások teljesítményét.

E fejezet felépítése a következő: a bevezetés és irodalmi áttekintés után bemutatjuk az általunk használt adatokat, mivel egy mintavételes mikroadatbázist elemzünk, kitérünk mintánk (makro adatokkal összevetett) reprezentativitására. A következő fejezetben részletesen bemutatjuk modellspecifikációnkat, elemezzük a becslésból kapott eredményeket és robusztusság vizsgálatot is végzünk. Külön részt szentelünk azon változóknak, amelyek empirikus megfigyelések alapján hatással lehetnek a nemteljesítési valószínúség alakulására, azonban a mi becslésünkbe végül nem kerültek be, és feltárjuk ennek okát. Ezután tárgyaljuk a jövedelemarányos törlesztőrészlet és a hitelkockázatok kapcsolatát, végül összegezzük fontosabb megállapításainkat.

\subsection{Adatok}

2013 augusztusában a Magyar Nemzeti Bank egy kérdôíves felmérés keretében gyưjtött információkat a hitellel rendelkezô háztartásokról. A felmérés célja az volt, hogy az MNB mélyebb információkhoz jusson a háztartások pénzügyi helyzetérôl, eladósodottságáról, megtakarítási szokásairól. A GfK Hungária segítségével elkészült felmérésben csak olyan háztartások vettek részt, ahol legalább az egyik tagnak volt valamilyen hitele. Az 1000 megkérdezett háztartásnak összesen 1322 
hitelszerződése volt a felmérés időpontjában. A hitelszerződések között darabszám szerint a lakáshitelek képviselték a legnagyobb súlyt, hiszen ezekból 341-ról kaptunk információt. Ugyancsak jelentős mennyiséget képviseltek a személyi hitelek (196), a folyószámlahitelek (176), a szabadfelhasználású jelzáloghitelek (163), illetve a gépjármú-hitelek (138). A diákhitelek (28) és a kártyahitelek (83) darabszáma viszont alacsony volt.

A felmérés során fontos cél volt, hogy a minta több szempontból is reprezentatív legyen: egyrészt reprezentálja a hitellel rendelkezô háztartásokat a fontosabb társadalmi és szociális jellemzôk (például háztartás összetétele vagy a lakóhely településtípusa) szerint, másrészt az egyes termékek állományarányos értéke megfeleljen a bankrendszerben látottaknak. Mivel a hitellel rendelkező háztartások szociális jellemzők szerinti eloszlásait nem ismerjük, ezért csak az összes háztartás eloszlásával tudjuk összevetni a felmérés eredményeit, amely összehasonlítás így mutathat eltéréseket, azonban viszonyítási pontnak felhasználható.2 Településtípus szerint például az 1000 megkérdezettból 201 budapesti volt, ami nagyjából megfelel a budapestiek 18 százalékos lakosságon belüli arányának. 251 kitöltô volt, aki valamelyik megyeszékhelyen lakik, ami kissé felülmúlta a tényleges, 20 százalékos arányt. Az egyéb városok 37 százalékos aránya ugyancsak kissé nagyobb, mint az országos, 30 százalék körüli érték. Így összességében a községekból származó adósok aránya maradt el az összes háztartáson belüli 30 százaléktól. A többi változó esetében is tapasztalhatók kisebb-nagyobb különbségek a felmérés során kapott és az országos eloszlás között. A településtípuson kívül például mintánkban nagyobb a magasabb iskolai végzettséggel rendelkezők és a munkapiacon aktívak aránya, ahogy a háztartások átlagos jövedelme is meghaladja az országos átlagot. Ezen különbségek vélhetően nagyrészt abból származnak, hogy a hitelkibocsátók csak hitelképes ügyfeleknek nyújtanak hitelt, akik nagy valószínúséggel vissza tudják fizetni az adósságukat, vagy kellő fedezettel rendelkeznek. Így a felmérésben az országos eloszláshoz képest érthető módon felülreprezentáltak a kedvezőbb vagyoni, jövedelmi és munkapiaci helyzetben lévô háztartások.

\footnotetext{
${ }^{2}$ A háztartások szociális jellemzóinek eloszlásáról képet kaphatunk a HKF alapján, azonban, mivel a HKF a háztartási hitelek eloszlása szempontjából nem reprezentatív (például a nemteljesítési adatokkal kapcsolatban), ezt az adatforrást sem használhatjuk összehasonlítás céljából.
} 
3. fejezet. A nemteljesítési valószínúség és az optimális jövedelemarányos törlesztốrészlet-szabály modellezése egy háztartási kérdőíves felmérés felhasználásával

3.1. táblázat: A különbözô hiteltermékek állományarányos eloszlása a mintában és a bankrendszerben

\begin{tabular}{|l|l|l|l|}
\hline & $\begin{array}{l}\text { Állomány a min- } \\
\text { tában (millió Ft) }\end{array}$ & $\begin{array}{l}\text { Eloszlás a } \\
\text { mintában }\end{array}$ & $\begin{array}{l}\text { Bankrendszeri } \\
\text { eloszlás }\end{array}$ \\
\hline Lakás & 1670 & $59 \%$ & $51 \%$ \\
\hline $\begin{array}{l}\text { Szabadfelhaszná- } \\
\text { lású jelzálog }\end{array}$ & 806 & $28 \%$ & $31 \%$ \\
\hline Gépjármú & 178 & $6 \%$ & $5 \%$ \\
\hline Személyi & 109 & $4 \%$ & $5 \%$ \\
\hline Áru & 15 & $1 \%$ & $1 \%$ \\
\hline Hitelkártya & 11 & $0 \%$ & $6 \% *$ \\
\hline Folyószámla & 11 & $0 \%$ & \\
\hline Diák & 30 & $1 \%$ & $2 \% *$ \\
\hline Egyéb & 13 & $0 \%$ & \\
\hline
\end{tabular}

Megjegyzés: A bankrendszeri eloszlásban csak a folyószámla- és a hitelkártyahitelek, illetve a diákés egyéb hitelek együttes eloszlása ismert, ezeket jelöltük csillaggal. Forrás: MNB és kérdőíves felmérés.

A terméktípusok állományarányos eloszlása szinte teljesen megegyezik a bankrendszerben látott adatokkal. A felvétel idôpontjában a bankrendszeri hitelállomány 51 százaléka volt lakáshitel, míg a mintánkban ez az arány 59 százalék. A szabadfelhasználású jelzáloghitelek tényleges aránya 31 százalék volt, ami nem tér el lényegesen a mintánkban látott 28 százalékos aránytól. Állományarányosan lényeges eltérést a mintában csak a folyószámlahitelek és a hitelkártyák mutatnak. Ez érthetô, hiszen a szerzôdések mérete kicsi, és a darabszámuk magas. Éppen ezért lényegesen több embert kellett volna megkérdezni, hogy ezek esetében is megfelelőek legyenek az állományarányos értékek. Mivel elemzésünkben fóként a jelzáloghitelekre fókuszálunk, így ez az eltérés nem befolyásolja eredményeinket.

A háztartási hiteleknél kiemelt kérdés az állomány devizális összetétele, hiszen ebből származik a portfólió egyik legfontosabb kockázata. Éppen ezért megnéztük, hogy a felmérés során elkészült minta devizális összetétel szerint mennyire felel 
3.2. táblázat: A különböző hiteltermékek állományi devizális eloszlása a mintában és a bankrendszerben

\begin{tabular}{|l|l|c|c|c|c|}
\hline & Hiteltípus & HUF & EUR & CHF & JPY* \\
\hline Felmérés & Lakás & 30 & 7 & 60 & 3 \\
\hline & Szabadfelhasználású jelzálog & 11 & 11 & 78 & 0 \\
\hline & Gépjármú & 26 & 3 & 70 & 0 \\
\hline \multirow{2}{*}{ Bankrendszer } & Személyi & 87 & 1 & 12 & 0 \\
\hline & Lakás & 45 & 7 & 48 & \\
\hline & Szabadfelhasználású jelzálog & 18 & 9 & 73 & \\
\hline & Gépjármú & 32 & 2 & 66 & \\
\hline & Személyi & 81 & 2 & 17 & \\
\hline
\end{tabular}

Megjegyzés: A táblázatban feltüntetett értékek százalékok, *bankrendszeri szinten csak HUF/EUR/egyéb deviza eloszlás ismert. Forrás: MNB és kérdőíves felmérés.

meg a bankrendszeri adatoknak. A fóbb termékek esetén egy kivétellel nem látunk jelentôsebb eltérést. Egyedül a lakáshitelnél tapasztaljuk azt, hogy a mintában nagyobb részt képeznek a CHF- és JPY-hitelek, mint a valóságban. A forinthitelek pedig éppen emiatt alulreprezentáltak. A többi terméktípus esetében nem látunk szignifikáns eltérést, így megállapíthatjuk, hogy összességében devizális összetétel szempontjából is megfelelő a mintánk.

Végül késedelem szempontjából is összehasonlítottuk mintánkat a bankrendszeri adatokkal. Ez azért is különösen fontos, mert elemzésünk elsôdleges célja a háztartási hitelek nemteljesítési okainak feltárása. Itt már csak a jelzáloghitelekre fókuszáltunk, mert a késóbb bemutatásra kerülố modellünk is kizárólag a jelzáloghitelek nemteljesítési valószínúségével foglalkozik. Késettség szempontjából kiemelt figyelmet érdemel a 90 napon túli (3 hónapon túli) késedelem, hiszen ezt tekintjük nemteljesítô hitelnek. A vizsgált termékek között az ennek a definíciónak megfelelő nemteljesítő hitelek aránya a bankrendszeri és a mintából kapott számoknál megegyeznek. Mind a lakáshiteleknél, mind a szabadfelhasználású jelzáloghiteleknél elhanyagolható, 1-2 százalékpontos az eltérés. 
3. fejezet. A nemteljesítési valószínúség és az optimális jövedelemarányos törlesztốrészlet-szabály modellezése egy háztartási kérdőíves felmérés felhasználásával

3.3. táblázat: A különbözô jelzáloghitelek késettség szerinti állományi eloszlása a mintában és a bankrendszerben

\begin{tabular}{|l|l|l|l|l|l|}
\hline & Hiteltípus & Nincs & $\begin{array}{l}1 \text { hónapnál } \\
\text { kevesebb }\end{array}$ & $\begin{array}{l}1-3 \text { hónap } \\
\text { között }\end{array}$ & $\begin{array}{l}3 \text { hónapnál } \\
\text { többet }\end{array}$ \\
\hline Felmérés & Lakás & 67 & 8 & 10 & 14 \\
\hline & $\begin{array}{l}\text { Szabadfelhaszná- } \\
\text { lású jelzálog }\end{array}$ & 51 & 6 & 13 & 30 \\
\hline Bankrendszer & Lakás & 75 & 9 & 4 & 13 \\
\hline & $\begin{array}{l}\text { Szabadfelhaszná- } \\
\text { lású jelzálog }\end{array}$ & 53 & 12 & 7 & 28 \\
\hline
\end{tabular}

Megjegyzés: A táblázatban feltüntetett értékek százalékok. Forrás: MNB és kérdôíves felmérés.

Összefoglalva, a jelenlegi felmérésben felvett minta legnagyobb előnye, hogy a hitelállomány összetétele szempontjából reprezentatív, amit a több korábbi elemzéshez használt HKF nem teljesít. A HKF-be a háztartások hiteleire vonatkozó, részletes kérdésblokk csak 2010-től került be. Ugyanakkor például átstrukturálásra vagy árfolyamgátra vonatkozóan adatokat a késôbbi években készült HKF-ek sem tartalmaznak. Továbbá, teljesítési képesség szempontjából a bankrendszeri NPLrátákkal összehasonlítva a HKF adatai nem reprezentálják jól a háztartásokat.

\subsection{A nemteljesítési valószínûség modellezése}

\subsubsection{A modell struktúrája}

Mivel a felmérés adatai az ellenórizhetô tulajdonságok alapján reprezentatívak, ezért alkalmasak a háztartási hitelek vizsgálatára. Fontos azonban megemlíteni, hogy a 2011-es végtörlesztés, valamint a többi végtörlesztett vagy elôtörlesztett hitel miatt némiképp rosszabb a mostani hitelállomány teljesítménye, mint a válság előtt ténylegesen kibocsátott állományé. A végtörlesztés során a bankrendszerból többnyire olyan ügyfelek kerültek ki, akik jól teljesítettek. Becsléseink segítségével arra a kérdésre kerestük a választ, hogy mely tényezók játszanak releváns szerepet 
a jelzáloghitelek nemteljesítési valószínúségének alakulásában, illetve ezen változók hatását számszerúsítettük is. Vagyis nem egyetlen tényezô és a csődkockázat kapcsolatát akartuk megvizsgálni, hanem a felmérésben begyújtött adatok alapján akartunk egy, a csôdkockázatot megfelelően mérô modellt kialakítani.

Az adatok struktúrája keresztmetszeti, bináris változós ökonometriai modellek becslésére adott lehetőséget. Célváltozóul a felmérés törlesztési késedelemre vonatkozó kérdését választottuk, ha az adott jelzáloghitel 90 napon túli törlesztésfizetési elmaradásban van, akkor az eredményváltozónk egyes értéket vesz fel, egyébként nullát. A szakirodalomban megszokott definíció, hogy a 90 napon túli késedelemtôl tekintik nemteljesítőnek a szerződést, ezért követtük mi is ezt a gyakorlatot. Ugyanakkor, a nemteljesítési valószínúség (a továbbiakban - az angol terminológia alapján - röviden PD - probability of default) értelmezése időhorizont szempontjából - a rendelkezésünkre álló adatokból kifolyólag - némileg különbözik a megszokottól. A becsült, illetve elôrejelzett PD-értékek általában egy éven belüli nemteljesítôvé válásra vonatkoznak. Mivel az általunk használt adatbázisban nem szerepel, hogy az adós pontosan mikor esett 90 napon túli késedelembe és keresztmetszeti struktúrában végeztük a becslést, egy éven belüli PD helyett a becsült PD-értékek azt mutatják, hogy mennyi a nemteljesítés valószínúsége a hitelfolyósítás óta eltelt idôtôl a mintavétel időpontjáig. A megnevezésben ezért hosszú távú PD-ként fogunk hivatkozni rá. Ezen definíció hátránya, hogy a becslésben gondot okozhat, hogy az egyes hiteleknél igen eltérô lehet a folyósítás óta eltelt idô (a legkorábbi hitel szerződéskötése 1978-ban, míg a legkésóbbié 2013-ban történt). Ugyanis általánosan megfigyelt tény a jelzáloghiteleknél, hogy késedelembe esés szempontjából a futamidő elsố 5 éve az igazán kritikus. Azon hitelek, amelyek az első 5 évben végig teljesítốk maradnak, már nagyon kis valószínúséggel esnek késóbb késedelembe.

A minta 20 százaléka 2008 utáni szerzôdés, amelynél még a legkockázatosabb 5 év sem telt el, így ezen hitelek között a nemteljesítők aránya csak ebból fakadóan (minden más tényezô változatlansága mellett) is alacsonyabb lehet. Szintén a ténylegesnél alacsonyabb lehet a megfigyelt nemteljesítési arány a tíz évnél régebbi hitelek esetén, mivel a futamidejük elején nemfizetôvé vált ügyfelek egy részénél már azóta a nemfizetés utáni szakasz is lezárulhatott. A minta 2004 előtti és 2008 utáni részének elhagyásával azonban értékes információt veszítenénk: a megfigyelé- 
3. fejezet. A nemteljesítési valószínúség és az optimális jövedelemarányos törlesztốrészlet-szabály modellezése egy háztartási kérdőíves felmérés felhasználásával

sek 35\%-át, és azon belül is a forinthitelek 69\%-át kényszerülnénk elhagyni. Ezért úgy döntöttünk, a teljes mintát használjuk, amennyiben a 2004-2008-as idôszakra szúkített és a teljes mintán kapott becslések között nem tapasztalunk jelentôs különbséget.

Mivel a mintában előfordultak olyan háztartások, amelyek több jelzáloghitellel is rendelkeztek, a becsléseket szerződésszintú és háztartásszintú adatokon is el lehetett volna végezni. Előbbi mellett döntöttünk két okból: egyrészt szerződésszintú adatokból nagyobb mintaméret állt elő, másrészt volt példa olyan háztartásra, ahol az egyik hitel már 90 napon túli késedelembe esett, míg a másiknál nem volt törlesztési probléma. Ezt háztartási szintú adatok használatával nem lehetett volna megfelelően kezelni.

A hitelek teljesítési valószínúségének alakulása szempontjából hat tényezôt gondoltunk meghatározónak: háztartás eladósodottsága, jövedelmi helyzete, munkapiaci aktivitása, nem hitel jellegú kiadások nagysága, a hitelek kockázattal kapcsolatos jellemzôi, háztartás szociális jellemzői. Ezek mérésére általában több lehetôség is van, mivel eltérô módon definiált mutatók is kifejezhetik például a háztartás munkapiaci helyzetét. Ezen változók sokszor (a hitel teljesítése szempontjából) ugyanazt az információt ragadják meg, azonban elófordulhat olyan is, hogy elvileg ugyanazt a tényezôt reprezentáló változók egymáshoz képest tartalmaznak releváns információt. Ezért a következô stratégiát követtük: alapvetôen tényezónként mindig a legszignifikánsabb, legnagyobb hatású változót tartottuk meg, de ha volt még olyan változó az adott tényezốcsoportban, ami ezen változó mellett is szignifikánsnak bizonyult, az is bekerült a becslésbe. $?^{3}$

A hat változócsoport közül az eladósodottságnál egyértelmúen pozitív elôjelet vártunk, vagyis a növekvô eladósodottság növekvô csődvalószínúséggel párosul. Az eladósodottságot figyelembe vevő változóként szerepeltettük a törlesztôrészlet alakulását (kezdeti, aktuális, egy keresóre jutó, jövedelem arányos), az LTV nagyságát, a felvett hitelösszeget, illetve az egyéb hitelekből származó törlesztőrészletet. A jövedelmi helyzet szintén fontos tényezô a hitel teljesítményénél, hiszen a jobb jövedelmi helyzet minden más változatlansága mellett kisebb csődkockázattal kell,

\footnotetext{
${ }^{3}$ Kiindulásként stepwise algoritmussal határoztuk meg az elsô modellverziót, majd ezt próbáltuk egyéb, érdemi változókkal bơvíteni.
} 
hogy párosuljon. Ezt a teljes háztartás jövedelmével, illetve az egy före jutó jövedelemmel vettük figyelembe. A jövedelmi helyzethez hasonló várakozásunk van a munkapiaci aktivitásnál is. A javuló munkapiaci helyzet csökkenti a csődvalószínúséget, amit a munkapiacon aktív, keresettel rendelkezôk háztartáson belüli aránya hivatott mérni. A háztartási kiadások növekedése adott jövedelem mellett csökkenti a törlesztésre fordítható keresetet, ami végsô soron a csődvalószínúség növekedését jelenti.

A hiteljellemzôk, illetve a háztartási jellemzók igen változatosak lehetnek, így ezeknél az előjel sem egyértelmú. A hiteljellemzôk között a legfontosabbak voltak: denomináció (deviza esetén nagyobb csődvalószínúséget várunk), hiteltípus (szabadfelhasználású hitelek teljesítménye rosszabb), felvétel idôpontja (azt vártuk, hogy a 2007-08-as időszakban felvett hitelek kockázatosabbak), LTV 100\% fölötti (ez is nagyobb kockázatot jelenthet), közvetítôn keresztül kötött szerződés (nagyobb PD-t várunk esetükben). Végül a háztartási jellemzők között a következóket néztük: a magasabb iskolai végzettség esetében kisebb PD-t vártunk; a lakhely típusánál a kisebb településeken várunk nagyobb PD-t; végül pedig úgy gondoljuk, hogy azok a háztartások, akiknek van megtakarításuk kisebb kockázatot jelentenek ${ }^{4}$ A becsült modellünket tehát a következóképpen írhatjuk fel:

$$
\begin{aligned}
y(0= & \text { teljesítô, } 1=\text { default })=G\left(\beta_{0}+\beta_{1} * \text { eladósodottság }+\right. \\
& +\beta_{2} * \text { jövedelmi helyzet }+\beta_{3} * \text { munkapiaci aktivitás }+ \\
& +\beta_{4} * \text { háztartási kiadások }+\beta_{5} * \text { hiteljellemzôk-dummy }+ \\
& \left.+\beta_{6} * \text { háztartásjellemzők-dummy }\right) \\
& \text { ahol } G(x)=\frac{e^{x}}{1+e^{x}} .
\end{aligned}
$$

A végső, itt bemutatott modellben már csak az 5 százalékos szinten szignifikánsnak bizonyult magyarázóváltozók szerepelnek 5 . A késôbbi számításoknál már erre a modellre fogunk támaszkodni. A bináris változós becslési eljárások közül

\footnotetext{
${ }^{4}$ A teljes listát a Függelék 5.3, 5.4, 5.5, 5.6 os táblázatai tartalmazzák, amelyekben a változók közötti korrelációkat is feltüntettük.

${ }^{5} \mathrm{~A}$ felsorolt magyarázóváltozók bizonyos interakcióit és négyzetes változatát is kipróbáltuk, azonban ezek nem bizonyultak szignifikánsnak
} 
3. fejezet. A nemteljesítési valószínúség és az optimális jövedelemarányos törlesztốrészlet-szabály modellezése egy háztartási kérdőíves felmérés felhasználásával

a logit-becslést választottuk, a módszerre való robusztusság ellenőrzésére a kapott magyarázóváltozókkal lineáris valószínúségi modellt is illesztettünk. A megmaradt magyarázóváltozók közötti korreláció alapján extrém multikollinearitás nem tapasztalható (Függelék 5.6-os táblázata). Az eredményeket mutatja a 3.4 es táblázat.

\subsubsection{Parciális hatások}

A felsorolt változók közül végül (a konstanson felül) hét magyarázóváltozó bizonyult szignifikánsnak. Mivel logit-becslés esetén a parciális hatások megfigyelésenként eltéróek (szemben a lineáris valószínúségi modellel), az irodalomban szokásos, átlagos parciális hatásokat tüntettük fel. A logit-modell illeszkedésével kapcsolatos információkat (helyesen besorolt megfigyelések aránya, Hosmer-Lemeshow-teszt) tartalmaz a Függelék 5.8 as táblázata, ezek alapján egyik szokásos szignifikanciaszinten sem vethetjük el a modell jó illeszkedését.

A szignifikánsnak bizonyult változók közül elôször a háztartási jellemzóket sorra véve, a háztartás munkapiaci aktivitás, illetve jövedelmi helyzet szerinti összetételét méri a „keresettel rendelkezők a háztartás létszámának arányában” változó. A becslés szerint, minél több jövedelemmel rendelkezô személy van egy háztartáson belül, annál kisebb a nemfizetôvé válás valószínúsége, számszerúleg például, ha ceteris paribus 2-rôl 3-ra nô a keresók száma egy 4 fốs háztartáson belül, a hosszú távú PD 8,14 százalékponttal csökken (egy háztartáson belül átlagosan a tagok fele keresô).

A jövedelemarányos törlesztőrészlet (angol terminológia alapján röviden PTI - payment-to-income) változó azt méri, hogy a háztartás számára mekkora terhet jelent a hitel visszafizetése, mekkora az eladósodottság mértéke. Itt kell megjegyeznünk, hogy, bár a felmérés kérdései között szerepelt egy, a háztartás jövedelmére vonatkozó kérdés is, arra sok esetben nem érkezett be értékelhetô válasz. Ugyanakkor a háztartások kiadásaira és megtakarításaira is részletes kérdésblokk vonatkozott, amelyek összege (a törlesztőrészletekkel együtt elviekben) a jövedelmet eredményezi. Ezen részek kitöltöttsége lényegesen magasabb volt, mint a jövedelemé, így ezzel a mesterséges változóval közelítettük a háztartás jövedelmét. Továbbá, a háztartás 
3.4. táblázat: A becsült modell változóinak átlagos parciális hatásai és szignifikanciaszintjei

\begin{tabular}{|c|c|c|c|}
\hline Változó & Logit & Logit 2004-2008 & Lineáris \\
\hline Konstans & $-19,24^{* * *}$ & $-29,28^{* * *}$ & $-2,19$ \\
\hline $\begin{array}{l}\text { Keresettel rendelkezók a } \\
\text { háztartás létszámának ará- } \\
\text { nyában ( } 25 \text { százalékpontos } \\
\text { növekedés) }\end{array}$ & $-8,14^{* * *}$ & $-8,53 * * *$ & $-7,85^{* * *}$ \\
\hline $\begin{array}{l}\text { Jövedelemarányos törlesztő- } \\
\text { részlet (PTI) (1 százalék- } \\
\text { pontos növekedés) }\end{array}$ & $0,76^{* * *}$ & $0,89 * * *$ & $41,26 * * *$ \\
\hline Devizában denominált & $5,70 * * *$ & $7,90^{*}$ & 2,96 \\
\hline $\begin{array}{l}\text { Egyéb hitelekből származó } \\
\text { jövedelemarányos törlesztô- } \\
\text { részlet (1 százalékpontos } \\
\text { növekedés) }\end{array}$ & $0,24^{* * *}$ & $0,28 * * *$ & $0,24^{* * *}$ \\
\hline $\begin{array}{l}\text { Egy keresőre jutó törlesztő- } \\
\text { részlet (10.000 Ft-os növe- } \\
\text { kedés) }\end{array}$ & $-3,05 * * *$ & $-3,45^{* * *}$ & $-3,97^{* * *}$ \\
\hline $\begin{array}{l}\text { Törlesztőrészleten felüli ki- } \\
\text { adások (10.000 Ft-os növe- } \\
\text { kedés) }\end{array}$ & $0,21^{* *}$ & $0,25 * * *$ & 0,33 \\
\hline Közvetítőn keresztüli hitel & $5,46^{* * *}$ & $7,53 * * *$ & $5,63 * * *$ \\
\hline
\end{tabular}

A táblázatban a csillagok szignifikanciaszinteket mutatnak: egy csillag a 10\%-on, két csillag az 5\%-on és három csillag az 1\%-on szignifikáns változókat jelöli. A parciális hatás értelmezésénél feltüntettük azt is, hogy milyen egységre vetítve kell értelmezni az eredményeket. Erre azért volt szükség, mert volt olyan változó, amelynél a mutató mértékegységére vetített parciális hatás nehezen volt értelmezhetô. Ilyenre példa a ,keresettel rendelkezốk a háztartás létszámának arányában”, ahol 1 százalékpontos változást helyett a háztartás összetételének változásával számoltunk. 
3. fejezet. A nemteljesítési valószínúség és az optimális jövedelemarányos törlesztốrészlet-szabály modellezése egy háztartási kérdőíves felmérés felhasználásával

aktuális, azaz 2013. augusztusi PTI-jét szerepeltettük a becslésben (jövedelemadat hiányában felvételkori PTI nem állt rendelkezésünkre). Az eredmények alapján minél nagyobb egy háztartás adóssága jövedelmének arányában, annál nagyobb hitelének hosszú távú PD-je, mégpedig 1 százalékpontos PTI-növekedés átlagosan 0,76 százalékponttal magasabb hosszú távú PD-t eredményez (minden más változatlansága mellett).

A becslés alapján növeli egy hitel kockázatosságát, ha a háztartásnak további hiteleket is törleszteni kell, ezt a hatást ragadja meg az „egyéb hitelekból származó jövedelemarányos törlesztôrészlet”. Ezen változó átlagos parciális hatása $(0,24$ százalékpont) kisebb, mint a másik PTI változóé. Ennek oka valószínúleg, hogy az egyéb hitelekbe a fedezetlen hiteleket is beleértjük, és amennyiben egy háztartás nem képes egyszerre törleszteni a fedezetlen és a fedezettel rendelkező hitelét is, inkább előbbi esetében esik késedelembe. Így a fedezetlen hitellel történő eladósodás kevésbé rontja a fedezett hitelnél tapasztalható fizetési fegyelmet. A törlesztési képességet nem csak a törlesztôrészlet jellegú kiadások befolyásolják, azon háztartások esetében, ahol nagyobbak az egyéb (nem hiteltörlesztés) jellegú kiadások (élelmiszer, lakhatás, tartós és féltartós javak, stb.) a nemteljesítés valószínúsége is nagyobb: 10000 Ft-tal magasabb kiadások a hosszú távú PD-t átlagosan ceteris paribus 0,21 százalékponttal növelik.

Az eddig bemutatott eredmények előjelükben teljesen megfeleltek a gazdasági intuíciónak. Ezzel szemben meglepő lehet, hogy „az egy keresőre jutó törlesztôrészlet" változó előjele negatív, vagyis magasabb törlesztőrészlet alacsonyabb PD-t indukál. Ez a változó azonban nem a háztartás eladósodottságát ragadja meg: a parciális hatás definíciója szerint minden más változatlansága mellett az egy keresốre jutó törlesztôrészlet emelkedése csökkenti a hosszú távú PD-t. Mivel a többi változó között szerepel a PTI is, a változatlanság csak úgy állhat elő, ha a magasabb törlesztôrészlet mellett a jövedelem is magasabb. Ez a változó tehát az eladósodottság helyett sokkal inkább a jövedelmi helyzetet, vagy törlesztôrészlet helyett a háztartás számára teljesíthetô törlesztôrészletet méri.6 ${ }^{6}$ Ennek fényében

\footnotetext{
${ }^{6}$ Ahogy már említettük, a háztartás jövedelmi helyzetét csak közelíteni tudtuk egy mesterséges jövedelem változóval, az egy keresốre jutó törlesztôrészlet valószínúleg a tényleges jövedelmi változó hiánya miatt nyert ilyen jellegú értelmezést.
} 
viszont érthetô a parciális hatás negatív előjele is. Az alábbi állítást alátámasztandó, elvégeztük a becslést olyan formában is, hogy kihagytuk belóle a PTI változót. Ekkor valóban pozitív parciális hatást kaptunk a törlesztőrészlet változóra, ami így már az eladósodottságot ragadja meg (lásd Függelék 5.9 as táblázata7]).

A hitel tulajdonságaira vonatkozóan két változó bizonyult szignifikánsnak a becslésben. Egyrészt, a devizahitelek kockázatosabbak a forinthiteleknél, a devizadenomináció átlagosan 5,7 százalékponttal növeli a hosszú távú PD-t. Az árfolyam okozta törlesztôrészlet-növekedés mellett ez abból is következhet, hogy a devizahiteleknél gyakori volt a bankok részéról az egyoldalú kamatemelés. Ez ugyancsak növelte az adósok terheit. Másrészt, a közvetítôkön keresztüli hitelek ceteris paribus átlagosan 5,46 százalékponttal magasabb nemteljesítési valószínúséggel rendelkeznek a közvetlen banki hitelekhez képest. Utóbbi eredmény érdekes jelenség: eszerint a hitelközvetítôk a banki közvetlen hitelekhez képest egy kockázatosabb ügyfélkörhöz jutottak el, azonban a felmérésból kinyerhetô információk alapján arra nem sikerült fényt derítenünk, hogy pontosan milyen tényezők teszik kockázatosabbá ezen ügyfeleket (pusztán azt a következtetést vonhatjuk le, hogy az általunk kipróbált - akár szignifikánsnak talált, akár kihagyott - változók közül erre egyik sem nyújt magyarázatot). A közvetítôkön keresztüli hitelek kockázatosabb volta fakadhat abból, hogy a közvetítôknek kevesebb és rövidebb kapcsolatuk van az ügyféllel, mint a banki ügyintézóknek, és más módon történik a motiválásuk. Így a hitelszerzôdésekre jellemzô aszimmetrikus információs problémák közvetítôk esetén nagyobb mértékben jelentkeznek.

\subsubsection{Robusztusságvizsgálat}

Ahogy korábban említettük, a becslést a hitelek kibocsátási évének különbözôsége miatti lehetséges torzítások kiszúrésére egy szúkebb, viszonylag homogén mintán (2004-2008) is elvégeztük. A parciális hatások előjelükben teljesen megegyeznek a két mintán, ahogy a tíz százalékos szinten szignifikáns változók csoportja is. ${ }^{8} \mathrm{~A}$

\footnotetext{
${ }^{7}$ A becslésból ez esetben kihagytuk a törlesztôrészleten felüli kiadásokat, mivel inszignifikánsnak bizonyult ez a változó ebben a specifikációban.

${ }^{8} \mathrm{~A}$ szignifikanciaszintek kiszámításához White-féle heteroszkedaszticitás robusztus standard hibákkal számoltunk.
} 
3. fejezet. A nemteljesítési valószínúség és az optimális jövedelemarányos törlesztốrészlet-szabály modellezése egy háztartási kérdőíves felmérés felhasználásával

deviza-dummy kivételével pedig öt százalékos szignifikanciaszinten is azonos változókat választ ki a két modell. Az átlagos parciális hatások mértéke a szúkebb mintán abszolút értékben minden változó esetén némileg nagyobb, jelentôsebb különbség a két dummy-változó esetén tapasztalható. A deviza-dummy esetében ez azért sem meglepő, mert az ebben az idôszakban kibocsátott hitelek esetén lényegesen nagyobb volt az árfolyam volatilitásából fakadó törlesztôrészlet-emelkedés, mint az azt követô idôszakban. (A deviza-dummy becslése ugyanakkor a szúkebb mintán bizonytalanabb, mivel a vizsgált idôszakban arányaiban nagyon kevés a forintban denominált kibocsátott hitel.) Ezen különbségek mértéke véleményünk szerint nem tette indokolttá a minta leszúkítését. (Az eltérő évjáratú hitelek közötti különbség vizsgálatát más megközelítésben is megtettük, errôl bővebben egy késóbbi részben szólunk, szignifikáns hatást azonban ekkor sem találtunk.)

Az eredmények robusztusságát a becslési eljárás szempontjából ellenôrizendő, egy lineáris valószínúségi modellel is készítettünk becslést, amelyhez a logitmodellek által szignifikánsnak talált változókat használtuk fel. A deviza-dummyt leszámítva öt százalékos szinten a lineáris modell is szignifikánsnak talált minden változót. A parciális hatások előjelükben teljesen megegyeznek, nagyságrendjükben két esetben térnek el jelentôsebben: a deviza-dummy esetében és a PTI-nél, elóbbinél a lineáris modell alacsonyabb, utóbbinál magasabb parciális hatást becsül. Mivel a becslésben szereplő PTI nem a hitelfelvételkori helyzetre (erre nem áll rendelkezésünkre megfelelő információ), hanem a felmérés idejére vonatkozik, az árfolyamgyengülés hatása a PTI-ben is megmutatkozik. Így a mintában a devizahitelek PTI-je magasabb, mint a forinthiteleké. Ez okozhatja a két modell parciális hatásai között megfigyelhetô különbséget, vagyis a devizahiteleknél az árfolyamváltozás miatti kockázat a logit-modellnél nagyobb részt a deviza-dummyban, míg a lineáris modellnél a PTI-ben csapódhat le. A modell eredményei tehát ebből a szempontból is robusztusnak bizonyultak. 


\subsection{Kimaradt változók}

\subsubsection{Lakáshitel vs. szabadfelhasználású hitel}

A felmérés alapján készített modellbe több olyan változó sem került be, ami a megfigyelések alapján jó magyarázóerôvel kellene, hogy rendelkezzen. Nem bizonyult szignifikánsnak az eltérố terméktípusokra vonatkozó dummy változó. A nemteljesítô hitelekre vonatkozó statisztikák alapján pedig lényeges különbség van a két terméktípus teljesítménye között. Míg a lakáshitel-állományon belül a nem teljesítô hitelek aránya 15 százalék alatt volt 2013 végén, a szabadfelhasználású jelzáloghitelek esetében ez az arány megközelítette a 30 százalékot. Ezt az eltérést csak részben magyarázza az, hogy a szabadfelhasználású jelzáloghitelek között szinte nincs forintban denominált, míg a lakáshitelek között a forinthitelek aránya jelentôs. Ha pusztán a devizában denominált szabadfelhasználású jelzáloghiteleket nézzük, az NPL-arányok közötti különbség továbbra is jelentôs: a lakáshiteleknél 18 százalék, míg a szabadfelhasználású jelzáloghiteleknél itt is közel 30 százalék az NPL-ek részesedése a teljes állományból.

A fenti eltérés azt mutatja, hogy a csôdesemény valószínúségére jelentôs hatása lehet a terméktípusnak. Megvizsgáltuk, hogy ennek ellenére miért nem volt szignifikáns magyarázóereje a modellünkben a termék-dummynak. Megnéztük, hogy mik azok a tényezôk, amik hatással lehetnek a csődvalószínüségre, és jelentősen eltérnek a két különbözô termék esetén. Az elsô ilyen természetesen a fentebb is említett denominációs eltérés (a lakáshiteleknél csak az állomány 54 százaléka devizában denominált, míg a szabadfelhasználásúaknál az arány 80 százalék fölötti). Ez azonban nem ad magyarázatot arra, hogy a devizában denominált hitelek teljesítménye is eltér a két terméknél. Külön vizsgálva a két terméket további olyan tényezôkben találunk jelentôs eltéréseket, amelyeket a modellünkben valamilyen módon figyelembe veszünk, és növelik a nemteljesítés valószínúségét. Az elsô ilyen az átlagos PTI alakulása. A lakáshiteleknél a PTI értéke 27 százalék, míg a szabadfelhasználású jelzáloghiteleknél 33 százalék volt ugyanez a mutató. A magasabb PTI növeli a nemteljesítés valószínúségét. 
3. fejezet. A nemteljesítési valószínúség és az optimális jövedelemarányos törlesztốrészlet-szabály modellezése egy háztartási kérdőíves felmérés felhasználásával

3.1. ábra: Nemteljesítő hitelek aránya különböző hiteltípusoknál

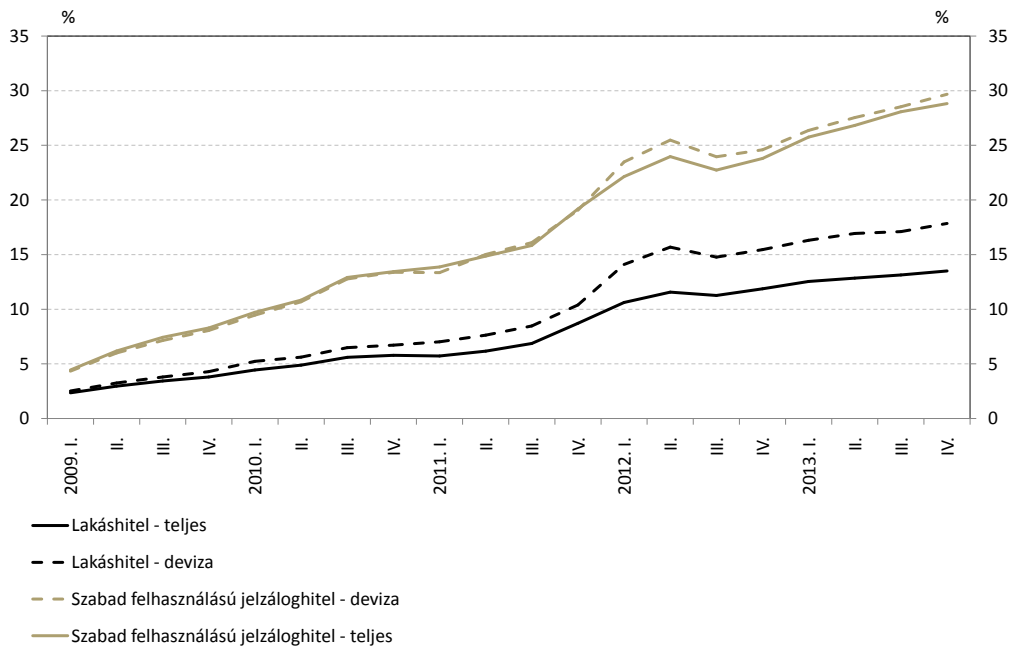

Forrás: MNB és kérdôíves felmérés

A szabadfelhasználású jelzáloghitelt felvevô adósok kockázatát ugyancsak növelte, hogy körükben jellemzóbb volt, hogy egyéb, fedezetlen hitellel is rendelkeztek. Ez önmagában csökkenti a törlesztési képességüket, hiszen ez plusz terhet jelent. Emellett az is fontos, hogy a devizahiteles mentő csomag folyamatos napirenden tartása a más hitellel is rendelkezô adósok esetében még inkább csökkentik a törlesztési hajlandóságot, mivel a törlesztés szüneteltetése lehetôvé teheti a fedezetlen hitelek visszafizetését. Az átlagos LTV (loan-to-value) alakulása ugyancsak fontos jellemzője az egyes hiteltípusoknak. Bár közvetlenül nem került be ez a változó a modellbe, a törlesztôrészleten keresztül részben ez a hatás is megjelenik. A szabadfelhasználású jelzáloghiteleknél az átlagos állományi LTV 17 százalékponttal magasabb, mint a lakáshiteleknél, vagyis a fedezethez képest nagyobb volt a felvett hitelek nagysága. Bár Magyarországon a magas LTV kevésbé meghatározó a visszafizetési hajlandóságnál, mindenképp kockázatnövelő tényezônek tekintjük. Mindezek mellett különbséget jelent, hogy a hitelfelvevőknek eltért a megtakarítási pozíciójuk. A lakáshitelt felvevôknek 12 százaléka rendelkezik megtakarítással, míg a szabadfelhasználású jelzáloghitel adósoknál ez a szám csak 5 százalék. 
3.5. táblázat: A szabadfelhasználású jelzáloghitelek és a lakáshitelek néhány tulajdonsága I.

\begin{tabular}{|l|l|l|l|l|}
\hline & LTV & PTI & $\begin{array}{l}\text { Van fedezet- } \\
\text { len hitele is }\end{array}$ & $\begin{array}{l}\text { Van megtaka- } \\
\text { rítása }\end{array}$ \\
\hline Lakáshitelek & 61 & 27 & 29 & 12 \\
\hline $\begin{array}{l}\text { Szabadfelhasználású jel- } \\
\text { záloghitelek }\end{array}$ & 78 & 33 & 33 & 5 \\
\hline Lakáshitelek (deviza) & 82 & 33 & 31 & 12 \\
\hline $\begin{array}{l}\text { Szabadfelhasználású jel- } \\
\text { záloghitelek (deviza) }\end{array}$ & 92 & 37 & 36 & 3 \\
\hline
\end{tabular}

Megjegyzés: a táblázatban szereplő értékek százalékok. Forrás: kérdőíves felmérés.

A két hiteltípus között eltérés mutatkozik a felvevook munkapiaci helyzete alapján is. A keresôk aránya a hitellel rendelkezô háztartásoknál ugyan nem tér el az egyes termékeknél, azonban az aktív keresók aránya már magasabb a lakáshitellel rendelkezők között. A PTI-ben mutatkozó eltérés egyik magyarázata, hogy a lakáshitelesek esetében a rendelkezésre álló jövedelem lényegesen magasabb, mint a szabadfelhasználású jelzáloghitellel rendelkezôknél. Hasonló különbség mutatkozik az egy fôre jutó jövedelemnél is. A lakáshiteleseknél lényegesen magasabb az átlagos egy fôre jutó kereset. Összességében tehát azt láthatjuk, hogy a szabadfelhasználású jelzáloghitellel rendelkezôk eleve kockázatosabb ügyfelek voltak munkaerôpiaci helyzetük, illetve a hitelek relatív nagysága alapján. Ezek a tényezók pedig szerepelnek a modellünkben, mint a nem teljesítés szignifikáns magyarázóváltozói.

\subsubsection{Vintage hatás}

A terméktípus mellett az intuíciók alapján a felvétel időpontjának is szignifikáns magyarázó erôvel kellene bírnia. Egyrészt a devizahitelezés elterjedésének és a deviza jelzáloghitel-állomány felépülésének időszakában (2004-2008) a háztartások sokkal szélesebb köre jutott hitelhez, mint akár az előtte, akár az utána lévô években, köszönhetôen - a fogyasztói viselkedésen túl - a bankok magas kockázati to- 
3. fejezet. A nemteljesítési valószínúség és az optimális jövedelemarányos törlesztốrészlet-szabály modellezése egy háztartási kérdőíves felmérés felhasználásával

3.6. táblázat: A szabadfelhasználású jelzáloghitelek és a lakáshitelek néhány tulajdonsága II.

\begin{tabular}{|l|l|l|l|l|}
\hline & $\begin{array}{l}\text { Keresók } \\
\text { aránya (\%) }\end{array}$ & $\begin{array}{l}\text { Aktív kere- } \\
\text { sốk aránya } \\
(\%)\end{array}$ & $\begin{array}{l}\text { Rendelkezésre } \\
\text { álló jövede- } \\
\text { lem (forint) }\end{array}$ & $\begin{array}{l}\text { Egy fóre jutó } \\
\text { jövedelem (fo- } \\
\text { rint) }\end{array}$ \\
\hline Lakáshitelek & 61 & 54 & 245482 & 76219 \\
\hline $\begin{array}{l}\text { Szabadfelhasználású } \\
\text { jelzáloghitelek }\end{array}$ & 61 & 46 & 225459 & 68607 \\
\hline $\begin{array}{l}\text { Lakáshitelek (devi- } \\
\text { za) }\end{array}$ & 62 & 54 & 260858 & 79410 \\
\hline $\begin{array}{l}\text { Szabadfelhasználású } \\
\text { jelzáloghitelek (de- } \\
\text { viza) }\end{array}$ & 63 & 46 & 230482 & 69884 \\
\hline
\end{tabular}

Forrás: kérdôíves felmérés.

leranciájának. Így ebben az idôszakban nem pusztán a devizadenomináció okozta a hitelek magasabb nemteljesítôvé válását. Másrészt, a hazai lakossági hitelezésrôl szóló elemzésekben több helyen is felmerült, hogy még az előbb említett idôszakon belül is megfigyelhetô különbség a hitelek átlagos teljesítménye között: a válság előtt közvetlenül, a 2007-2008-as periódusban a bankok egyre kockázatosabb ügyfeleknek adtak hitelt, és egyre rosszabb minôségû lett a portfólió. A Jelentés a pénzügyi stabilitásról kiadvány 2011 novemberében (MNB (2011) $)$ megjelent számában a különböző években kibocsátott hitelek teljesítményét vizsgáló 3.2-es ábra errôl tanúskodik. Míg a 2006-ban kibocsátott hitelek esetében a nemteljesítô hitelek 5 év után érték el a 7,5 százalékos arányt, addig a 2007-ben kibocsátottak már 4 év után 11 százalékon voltak, a 2008-ban kibocsátottak pedig 3 év alatt érték el ezt a 11 százalékos szintet. Ez azt mutatja, hogy valóban egyre kockázatosabbak voltak a háztartási hitelek.

Az általunk készített modellben mindezek ellenére nem volt szignifikáns a különbözô időszakokat megtestesítô dummy-változó, így érdemes megnézni, hogy az eltérő időszakok hitelei milyen karakterisztikákkal rendelkeztek. Bár a felmérés- 
3.2. ábra: A nemteljesítô hitelek aránya a különbözô időszakokban felvett háztartási deviza jelzáloghiteleknél

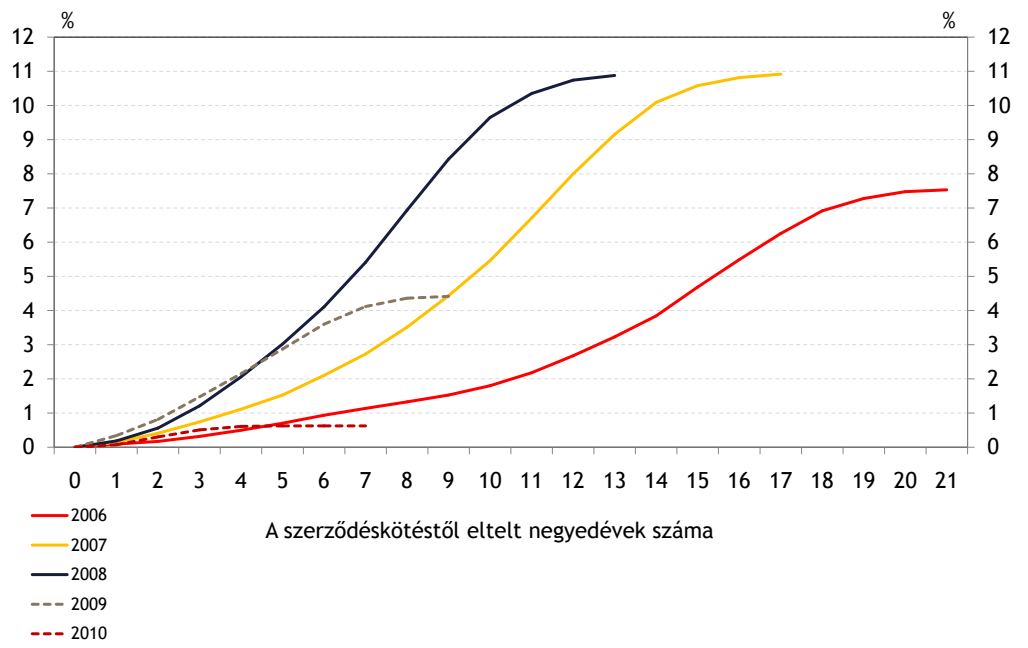

Forrás: MNB.

ben szerepeltek hitelek 2004 elóttról, illetve 2008-at követően is, mi a háztartási hitelezés legintenzívebb, 2004-2008 közötti idôszakában vizsgáltuk a „vintage” hatást. Ezt a periódust is kettébontottuk, a válságot közvetlenül megelôzô 2007-08as időszakra, illetve a felfutás kezdetét jelentô 2004-06-os időszakra. Erre a két idôszakra a vintage hatás erôsségét megvizsgáltuk úgy is, hogy a teljes mintába tettünk dummy-változókat (egy olyat, ami 2004-2006-os kibocsátás esetén vesz fel egyes értéket, és egy olyat, ami 2007-2008-as kibocsátás esetén), és úgyis, hogy csak a szúkített 2004-2008-as idôszaki mintát vettük figyelembe (és csak a 20072008-as idôszakot dummyztuk), de egyik esetben sem találtuk szignifikánsnak a változó(ka)t.

A termékbontáshoz ebben az esetben is végignéztük az egyes idôszakokban kibocsátott szerződések főbb jellemzőit. Az elsô jelentôs különbség, hogy az átlagos hitelnagyság több mint 1 millió forinttal nôtt a válságot közvetlenül megelőzô időszakban a korábbiakhoz képest. A futamidőben nincs jelentős eltérés a két időszak 
3. fejezet. A nemteljesítési valószínúség és az optimális jövedelemarányos törlesztốrészlet-szabály modellezése egy háztartási kérdőíves felmérés felhasználásával

között, de az itteni enyhe emelkedés is inkább a hitelek kockázatainak növekedésére utal. A denomináció nem csak az eltérô termékek teljesítménybeli különbségénél merült fel lehetséges magyarázatként, hanem a különbözô vintage-eknél is. Látható, hogy a 2007-08-as időszak kibocsátásain belül a devizahitelek aránya tovább nôtt, érdemben meghaladva a 2004-06-os idôszakra jellemzô, egyébként is magas 72 százalékot. Láthattuk, hogy a hitelek nagysága a második periódusban jelentôsen meghaladta az első periódusra jellemző értéket. Ez az adat önmagában csak sugallja, hogy a hitelek kockázata növekedett. Az LTV és PTI adat ezt a benyomást megerôsíti. Mind az átlagos PTI, mind az átlagos LTV lényegesen magasabb volt a második periódusban, mint az elsôben. Végül megnéztük azt is, hogy mennyire volt jellemző a két csoportnál egyéb, fedezetlen hitel felvétele. A két adat között nincs lényeges különbség, a második időszak azonban itt is kissé rosszabbul teljesít.

3.7. táblázat: A két vizsgált időszakban kibocsátott hitelek néhány tulajdonsága I.

\begin{tabular}{|l|l|l|l|l|l|l|}
\hline & $\begin{array}{l}\text { Hitelnagy- } \\
\text { ság (millió } \\
\text { Ft) }\end{array}$ & $\begin{array}{l}\text { Futami- } \\
\text { dô (év) }\end{array}$ & $\begin{array}{l}\text { Devizahite- } \\
\text { lek aránya } \\
(\%)\end{array}$ & LTV $(\%)$ & PTI (\%) & $\begin{array}{l}\text { Van fede- } \\
\text { zetlen hite- } \\
\text { le is }(\%)\end{array}$ \\
\hline $2004-2006$ & 4,23 & 18 & 72 & 64 & 27 & 30 \\
\hline $2007-2008$ & 5,51 & 20 & 84 & 88 & 36 & 33 \\
\hline
\end{tabular}

Forrás: kérdőíves felmérés.

Az eltérő periódusokban kibocsátott hiteleknél is megnéztük, hogy van-e eltérés a hitelfelvevôk munkapiaci helyzetében. Ezen a területen viszonylag kicsi eltérés mutatkozott a két csoport között, és az eltérések iránya nem egyértelmú. Míg az aktívak családon belüli aránya enyhén nagyobb a második periódus hitelfelvevôi között, addig a rendelkezésre álló jövedelem mind abszolút számként, mind egy fôre vetítve kisebb náluk. Az eltérés azonban egyik esetben sem lényeges. A munkapiaci helyzet tehát nem tekinthetô szignifikánsan eltérônek a két csoport között. Végül meg kell említenünk, hogy a két idôszak hiteleinél különbséget jelenthet a felvételkori árfolyam. Különösen 2008-ban nagyon erôs volt a forint árfolyama. Míg a 2004-06-os időszakban az átlagos forint-svájci frank árfolyam 163 volt, addig 2007- 
08-ban 155. Ez a tényező némiképp ugyancsak hozzájárulhat a teljesítményekben mutatkozó különbségekhez.

3.8. táblázat: A két vizsgált idôszakban kibocsátott hitelek néhány tulajdonsága II.

\begin{tabular}{|l|l|l|l|l|}
\hline & $\begin{array}{l}\text { Keresók } \\
\text { aránya (\%) }\end{array}$ & $\begin{array}{l}\text { Aktív kere- } \\
\text { sók aránya } \\
(\%)\end{array}$ & $\begin{array}{l}\text { Rendelkezésre } \\
\text { álló jövede- } \\
\text { lem (forint) }\end{array}$ & $\begin{array}{l}\text { Egy fóre jutó } \\
\text { jövedelem (fo- } \\
\text { rint) }\end{array}$ \\
\hline $2004-2006$ & 56 & 47 & 241693 & 71966 \\
\hline $2007-2008$ & 62 & 52 & 240146 & 69964 \\
\hline
\end{tabular}

Forrás: kérdőíves felmérés.

Összességében azt látjuk, hogy a két idôszak hitelei között nem az eltérô munkapiaci helyzet jelentette a fô különbséget, hanem a hitelfelvevô eladósodottsága az adott hitel felvétele után, ami alátámasztja Gáspár és Varga (2011) megállapításait. A feltárt különbségeket azonban a modellbe beépített egyéb változók (devizadummy, PTI) megfogják, így érthetô, hogy a vintage-dummy nem lett szignifikáns.

\subsubsection{Egyéb kimaradt változók}

Az eddig bemutatott két változó kimaradásának okai igényelték a legrészletesebb bemutatást, de ezek mellett is volt jó néhány, amit az adatbázis ugyan tartalmazott, és megnéztük a modellezés során a hatását, de nem bizonyult szignifikánsnak. Érdemes ezeket is sorba venni, és feltárni a kimaradás lehetséges okait. A hitel kockázatát leíró mutatók közül az egyik leggyakrabban használt az LTV. Az LTV magába foglalja a hitel nagyságát, ami így implicit utal a törlesztôrészlet nagyságára is. A magas törlesztőrészlet pedig emeli a nemteljesítés valószínúségét. Emellett a magas LTV a törlesztési hajlandóságot negatívan befolyásolhatja, hiszen, ha a hitel többet ér, mint az ingatlan, érdemes lehet hagyni bedólni. Ezért az LTV lehetséges hatásait kétféleképpen is megpróbáltuk figyelembe venni: maga az LTV folytonos változóként is bekerült a modellbe, valamint egy dummy-változó is, amely egyes értéket vesz fel, ha az LTV száz százalék fölé emelkedik (ekkor a fedezet kevesebbet ér, mint amennyivel az adós tartozik), egyébként nullát. Utóbbi mögött 
3. fejezet. A nemteljesítési valószínúség és az optimális jövedelemarányos törlesztốrészlet-szabály modellezése egy háztartási kérdőíves felmérés felhasználásával

az a megfontolás áll, hogy a törlesztéssel kapcsolatos hajlandóság romlása nem feltétlenül lineáris kapcsolatban van az LTV változásával, inkább egy lélektani határ (amelynek legkézenfekvőbb értéke a 100\%) elérte után romolhat drasztikusan. A relatíve magas törlesztôrészletból fakadó hatás a mi modellünkben azért nem releváns, mert ezt a hatásmechanizmust a PTI változó sokkal egyértelmúbben, jobban fogja meg. A második probléma esetünkben azért nem áll fent, mert egyrészt a magáncsôd intézménye Magyarországon a megfigyelt idôszakban még nem létezett, másrészt pedig a hitelfelvevôk döntôen a saját lakóingatlanjukat használták fedezetként a hiteleknél. A mintában alig 2 százalék azon jelzáloghitelek aránya, ahol nem a lakóingatlan a hitel fedezete. Így a csőd választása nem reális opció a hitelfelvevôknek.

Kipróbáltuk magyarázóváltozóként a törlesztôrészlet-változást, a kezdeti törlesztôrészletet, az aktuális törlesztôrészletet, de egyik sem bizonyult szignifikánsnak. A törlesztôrészlettel kapcsolatos információkat ugyanis több változó is tartalmazza, ezért nem volt meglepó, hogy ezek már nem lettek szignifikánsak. Az árfolyamváltozást ugyancsak megnéztük, mint magyarázóváltozót, de a változó információtartalmát a denomináció dummy magában foglalja, így szerepeltetése nem indokolt, és nem is lett szignifikáns. Emellett a PTI alakulása is részben tartalmazza ezt az információt. Hasonló okok, illetve vélhetően mintavételi problémák miatt nem lettek szignifikánsak és maradtak ki a háztartások jövedelmére vonatkozó változók (a háztartási jövedelme, illetve egy fớre jutó jövedelme). A PTI ugyanis ezen információk csôdvalószínúség szempontjából lényeges elemeit is tartalmazza. Végül ehhez kapcsolódik, hogy nem volt szignifikáns hatása annak, hogy van-e a hitelfelvevőnek fedezetlen hitele is. Ennek hatását az egyéb hitelekbôl származó jövedelemarányos törlesztôrészlet változó már magában foglalja.

A lakás- és szabadfelhasználású jelzáloghitelek között különbség volt, hogy az előbbi adósok között magasabb volt a megtakarítással rendelkezók aránya. Megnéztük azt is ezért, hogy a megtakarítások mekkora hatással vannak a hitelteljesítési valószínúségre. A változó azonban nem bizonyult szignifikánsnak. Ennek oka valószínúleg az volt, hogy nagyon kevés hiteladós háztartás rendelkezik bármilyen megtakarítással. A mintán belüli arányuk nem éri el a 10 százalékos szintet sem. 
Az iskolai végzettség gyakran jó magyarázóerővel bír a hitelek teljesítési valószínúségénél. Modellünkben azonban ez a változó nem bizonyult szignifikánsnak (referenciakategória a legfeljebb 8 általános végzettség volt, a magasabb iskolai végzettséget három dummy-változóval szerepeltettük a modellben). Ennek magyarázata, hogy az iskolai végzettség valójában a jobb munkapiaci helyzetet, jobb jövedelmi viszonyokat fogja meg. Ezeket a tényezôket azonban egyrészt a keresettel rendelkezôk háztartáson belüli aránya, másrészt a PTI, harmadrészt az egy fốre jutó törlesztôrészlet is magában foglalja. Hasonló logikával magyarázható, hogy a településtípusokra vonatkozó dummy-változók (megyeszékhely, megyei jogú város, egyéb város, község - referenciakategória Budapest volt) sem bírtak szignifikáns magyarázóerôvel. Csődvalószínűség szempontjából ebben az esetben is az a legfontosabb, hogy általában a nagyvárosokban jobbak a munkalehetôségek, így a jövedelmi viszonyok is, ami végsô soron csökkenti a jövedelemarányos törlesztôrészletet, és ezzel a csôdvalószínúséget.

Végül nem került a magyarázóváltozók közé az árfolyamgátba való belépés sem. Ez elsôsorban azért lehetett inszignifikáns, mert az árfolyamgátnak viszonylag rövid története volt 2013-ig. A felmérés felvételének idôpontjában alig egy éves volt az intézmény. Ezen hitelek teljesítményét így még korai lett volna értékelni. Ráadásul az árfolyamgátból adódó tehercsökkenés implicit benne van a törlesztôrészletet tartalmazó változókban is. Ez utóbbi magyarázhatja azt is, hogy az államilag támogatott kamatkonstrukciójú hitelekre vonatkozó dummy sem lett szignifikáns. A hitelek átstrukturálása rendszerint valamilyen törlesztési probléma miatt következik be, azonban az ilyen hitelek késóbb - az átstrukturálás ellenére - nagyobb arányban válnak újra nemteljesítôvé, mint a problémamentes hitelek. Ezért egy átstrukturálásra vonatkozó dummy-változót is szerepeltettünk a modellben, amely végül nem bizonyult szignifikánsnak. Ennek oka valószínúleg, hogy az átstrukturálásra kerülő hitelek már eleve kockázatosabbak voltak, amely kockázatot a modellben szereplő változóink megragadnak, ezért az átstrukturálás ténye nem hordoz többletinformációt. 
3. fejezet. A nemteljesítési valószínúség és az optimális jövedelemarányos törlesztốrészlet-szabály modellezése egy háztartási kérdőíves felmérés felhasználásával

\subsection{A jövedelemarányos törlesztőrészlet és a hitel- kockázat kapcsolata}

A fentebb bemutatott modell magyarázóváltozói közül érdemes külön figyelmet szentelni a jövedelemarányos törlesztőrészlet változónak. A PTI-t számos országban (így Magyarországon is) használják a különbözô banki szabályozó hatóságok. A PTI-re vonatkozó szabályozások jellemzôen egy limitet írnak elő, amelyet nem léphet túl a kibocsátott hitelek PTI-je. Ezzel egyrészt meg lehet akadályozni a hitelfelvevôk túlzott tehervállalását, másrészt a bankrendszer által vállalt hitelkockázatokat is részben korlátozni lehet. Ugyanakkor, egy indokoltnál alacsonyabb PTI-előírás feleslegesen leszúkíti a hitelezhető háztartások körét, akadályozva ezzel a gazdaság hatékony múködését és növekedését. A 2000-es évek elején több helyen is alkalmaztak PTI szabályozást, hogy gátat szabjanak a túlzott hitelezésnek, és megakadályozzák rendszerkockázatok felépülését. Az ismert esetekben (pl.: Kína, Korea, Románia) a szabályozó hatóságok sikeresnek értékelték a lépést, bár rendszerint egy nagyobb csomag részeként került bevezetésre, így az egyedi hatása nehezen értékelhető Borio és Shim (2007)). A PTI szabályozása Magyarországon is felmerült, sôt 2015 januárjától életbe lépett egy ezzel kapcsolatos szabályozás. Mindezek miatt fontos annak vizsgálata, hogy milyen kapcsolatban van egymással egy hitel hosszú távú PD-je és a hitelt felvevô háztartás PTI-je, illetve milyen PTI-értékektôl beszélhetünk egy hitel esetében túlzott kockázatvállalásról.

Modellbecsléseink alapján ezt a kérdést igyekszünk körbejárni a rendelkezésünkre álló adatok és a módszer adta lehetôségek segítségével..$^{9}$ Kiszámítottuk, hogy egy fiktív, a minta és egyéb információk alapján átlagosnak tekinthető háztartás hosszú távú PD-je hogyan alakul a PTI függvényében külön devizában, illetve forintban felvett hitel esetén. A háztartás a modell többi változója szempontjából átlagos:

\footnotetext{
${ }^{9} \mathrm{Meg}$ kell jegyeznünk azonban, hogy a szabályozói előírásként és az általunk használt PTI között van egy különbség: a jogszabályi előírás mindig a kezdeti, a hitelfelvételkori PTI-re vonatkozik, míg a mi becslésünkben a felméréskori, aktuális PTI szerepelt (erre vonatkozóan rendelkeztünk információval). A kettô között érdemi különbség lehet például az árfolyam-, kamat- és jövedelemváltozások miatt. Ez ugyanakkor véleményünk szerint nincs jelentôs torzító hatással a bemutatott eredményekre.
} 
négy főből áll, ebból kettő rendelkezik jövedelemmel, mely jövedelem a nemzetgazdasági nettó átlagjövedelem, 6\% az egyéb hitelekből származó jövedelemarányos törlesztőrészletük, jövedelmük 75\%-át fordítják fogyasztásra. A hitelük forinthitel esetén $22 \%$-os, devizahitel esetén $32 \%$-os valószínúséggel közvetítôn keresztüli hitel. A különböző PTI-értékekből pedig adódik az egy keresôre jutó törlesztôrészlet is.

3.3. ábra: A hosszú távú PD a PTI függvényében különböző denomináció és jövedelem mellett

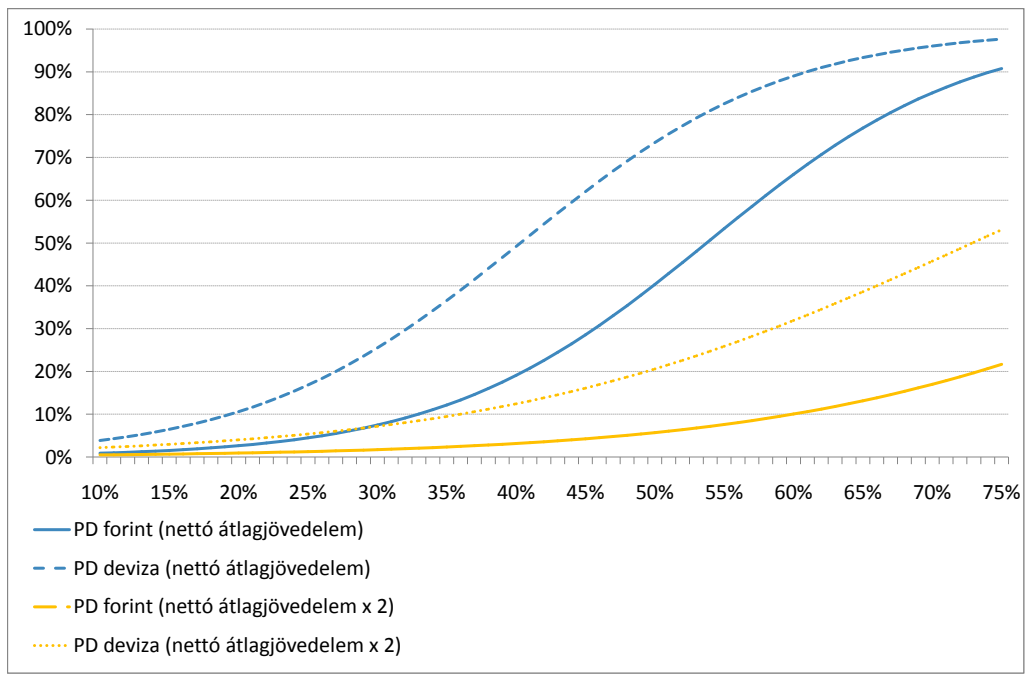

Az így kapott értékeket mutatja a 3.3 as ábrán kékkel jelölt két vonal. Kérdésként merülhet fel, hogy a bankrendszer természetes múködése mellett mi az a hosszú távú PD-szint, amely nem utal túlzott kockázatvállalásra. Az általunk megfigyelt mintában a jelenleg nemteljesítô hitelek darabszám alapján lakáscélú hitelek esetén 10, míg szabadfelhasználású hitelek esetén az összes hitel 17\%-át teszik ki. Ez azonban egy olyan idôszak megfigyelése, amelyre a kívánatosnál magasabb hitelezési kockázatok és a hitelfelvevôk túladósodása volt jellemzô. Tehát a kívánatosnak tekinthető PD-érték ennél alacsonyabb.

A pontosabb meghatározáshoz egy egyszerú, ökölszabályokból álló számítást végeztünk el. A jelzáloghitelek 2013-as magas, közel 20 százalékos NPL-rátáját a magas nemfizetési valószínúségek, a csökkenô hitelállomány és az alacsony portfóliótisz- 
3. fejezet. A nemteljesítési valószínúség és az optimális jövedelemarányos törlesztốrészlet-szabály modellezése egy háztartási kérdőíves felmérés felhasználásával

títási-ráták idézték elő. Egy egyszerú számítás eredményeként megkaphatjuk, hogy egy normál gazdasági ciklus feltételezései mellett a mostani bankrendszeri NPLarány a jelzáloghiteleknél kb. 5-6 százalék lenne. A számításnál egy 10 éves periódust vettünk figyelembe, ahol a hitelállomány évi 5,5 százalékkal nô (a nominális GDP növekedéssel egyezô ütem 2,5 százalékos reál növekedés és 3 százalékos infláció esetén), a nemteljesítés valószínúsége (a szokásos PD) 1,5 százalék, és a negyedéves tisztítási ráta 5 százalék. Ezen paraméterek mellett nagyjából 5,5 százalék lenne az NPL arány 10 év után. Ezt a mértéket elfogadhatónak tartjuk, és úgy gondoljuk, hogy tolerálható szint a bankrendszer számára. Ezt több tényező is alátámasztja. Megnéztük, hogy a hazai bankrendszernél lényegesen jobban teljesítô többi visegrádi országban az utóbbi néhány évben átlagosan milyen szintet ért el a háztartási NPL arány. Ez a szint pedig 5,6 százalék volt (3.4 es ábra). Emellett az államilag támogatott forint hitelek esetében a válságban látott 4,5-5 százalékos NPL arány is azt támasztja alá, hogy ez egy tolerálható szint. Nagyobb hitelállománynövekedésnél, vagy erőteljesebb tisztítás mellett természetesen az NPL-arány ennél lényegesen kisebb is lehet, de mi egy elfogadható maximumot kerestünk.

3.4. ábra: NPL-arány alakulása a válság alatt a régióban

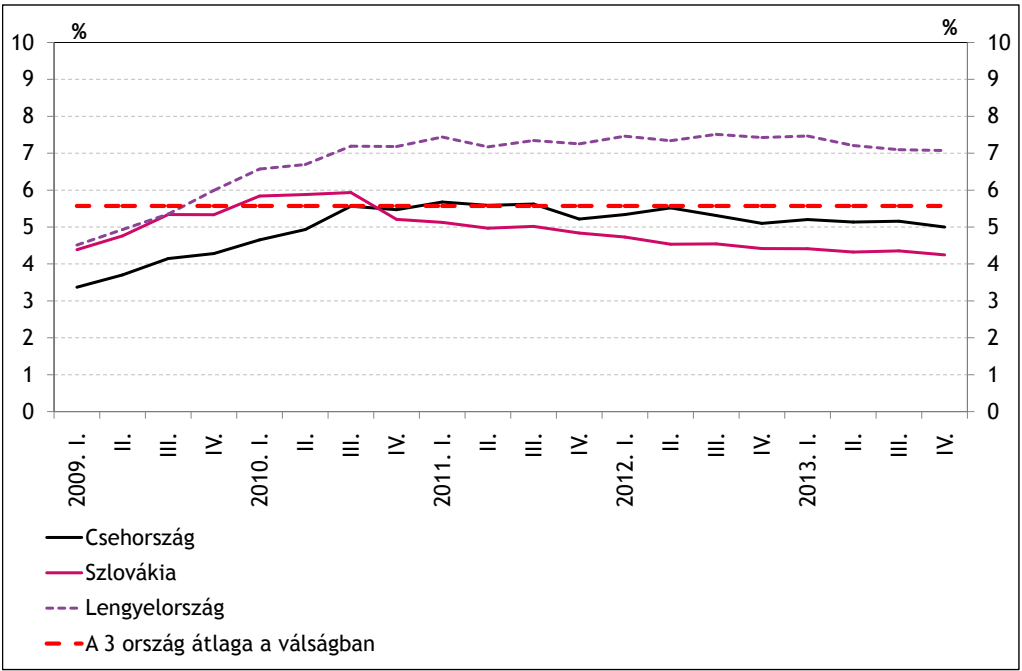

Forrás: EKB. 
A minta sajátosságából adódik, hogy tisztítást nem vehetünk figyelembe, bármilyen régóta is került késedelembe az adott hitel. Emellett állománynövekedéssel sem számolhatunk a mintán belül. Ezeket a tényezóket figyelembe véve 10-11\% között alakulna a tolerálható NPL-arány a portfólión belül (főként a tisztítás hiánya miatt) 100 Ez utóbbi tehát azt adja meg, hogy normális kockázatvállalási hajlandóság és a többi körülmény változatlansága mellett az általunk megfigyelt mintán mekkora lett volna a bekövetkezett nemteljesítési-arány. Mivel a becslésünkhöz használt PD-definíciónak a minta átlagában ez a realizált értéke, ezért a továbbiakban ezt a 10\%-os hosszú távú PD-t tekintjük a szabályozó számára még elviselhetố nagyságú kockázatvállalásnak.

Összehasonlítva a forintban és devizában denominált hiteleket, jelentôsen eltérô PTI mellett tekinthetô a két típusú hitel (nemteljesítés szempontjából) azonos kockázatúnak. Az elóbb említett 10\%-os hosszú távú PD-értékkel a forinthitelek esetén 38\%-os PTI, míg devizahiteleknél 24\%-os PTI konzisztens. Tehát a vizsgált idôszakban egy átlagos háztartás esetében a devizában való eladósodás annyival növelte a hosszú távú PD-t, mint egy 14 százalékpontos emelkedés a PTI-ben. Ez még akkor is jelentős különbség, ha tudjuk, hogy a devizahitelek törlesztési terhét az egyoldalú kamatemelések is növelték.

A nemteljesítési valószínüség és a jövedelemarányos törlesztőrészlet kapcsolatának alakulását a denomináción felül a háztartás jövedelmének függvényében is megvizsgáltuk. A háztartások jövedelmük emelkedésével jellemzôen annak egyre kisebb részét fordítják fogyasztásra: az alacsony jövedelmú háztartások esetében gyakran a fogyasztási-arány 100\%, míg a magasabb jövedelmi rétegek jelentős megtakarítások felhalmozására is képesek. Így a jövedelem emelkedésével a háztartás által teljesíthetô PTI is magasabb. A 3.3 ábránk megmutatja, hogyan változik a hosszú távú PD a PTI függvényében, ha a háztartás jövedelme a nettó átlagjövedelem kétszerese. Valamint a 10\%-os hosszú távú PD-hez és különbözô háztartási jövedelmekhez tartozó PTI-ket foglalja össze a 3.9 es táblázat. Eszerint forinthitellel és átlagos jövedelemmel rendelkezô háztartás esetén például a jövedelem megduplázódásával akár 20 százalékponttal magasabb PTI sem jelent túlzott adós-

\footnotetext{
${ }^{10} \mathrm{~A}$ mintánk ugyanis implicit azt feltételezi, hogy nincsen tisztítás.
} 
3. fejezet. A nemteljesítési valószínúség és az optimális jövedelemarányos törlesztốrészlet-szabály modellezése egy háztartási kérdőíves felmérés felhasználásával

3.9. táblázat: Egy átlagos háztartás 10\%-os hosszú távú PD-hez tartozó PTI-je különbözô jövedelmek és denomináció mellett (teljes minta)

\begin{tabular}{|l|l|l|l|l|l|}
\hline & $100000 \mathrm{Ft}$ & $150000 \mathrm{Ft}$ & $200000 \mathrm{Ft}$ & $250000 \mathrm{Ft}$ & $300000 \mathrm{Ft}$ \\
\hline Forint & 34 & 38 & 42 & 49 & 59 \\
\hline Deviza & 22 & 24 & 26 & 30 & 35 \\
\hline
\end{tabular}

Megjegyzés: a táblázatban feltüntetett értékek százalékok.

ságvállalást. Devizahiteleknél ez az érték kisebb, de továbbra is jelentôs, több mint 10 százalékpont.

Mivel a megfigyelt mintánk hitelfelvétel - és ebból fakadóan reálgazdasági és szabályozói körülmények - szempontjából jelentôs heterogenitást mutat, ugyanezen számításokat elvégeztük csak a 2004-2008 között felvett hitelekre is (ezen mintán becsült modellt már bemutattuk a robusztusságvizsgálat során is, ahol azt is megállapítottuk, hogy a kapott becslés nagyon hasonló a teljes mintán végzett becsléshez). Az eredményeket a 3.10 es táblázat foglalja össze. Összehasonlítva a számokat a 3.9 es táblázat megfelelő értékeivel, látható, hogy devizahitelek esetén nincs érdemi különbség a két mintán kapott becslések között. Forinthitelek esetén viszont 7-9 százalékkal magasabb értékeket kapunk minden jövedelmi kategóriában a szúkebb mintán végzett becslés esetén. Mivel a devizahitelek döntő többsége (83 százaléka) a szúkebb mintán került kihelyezésre, nem meglepô, hogy a két modell ugyanarra az eredményre jut. Forinthitelek esetén viszont csak a megfigyelések 36 százaléka esik erre az idôszakra, így a teljes mintához képest lényegesen kevesebb információt tartalmaz. Ezért forinthitelek szempontjából inkább a teljes mintán végzett becslési eredményeket tartjuk mérvadónak.

Egy másik lehetséges megközelítés az optimális PTI-szint meghatározására, ha a PTI-változót kategóriaváltozóként szerepeltetjük a becslésben dummyk segítségével (PTI $\leq 10 \%$ a referenciakategória, a további dummy-változók sorban 1es értéket vesznek fel, ha: $10 \%<\mathrm{PTI} \leq 20 \%, 20 \%<\mathrm{PTI} \leq 30 \%, 30 \%<\mathrm{PTI} \leq 40 \%$, $40 \%<\mathrm{PTI} \leq 50 \%, 50 \%<\mathrm{PTI} \leq 60 \%, \mathrm{PTI}<60 \%)$. Azt kaptuk, hogy az elsố két dummy nem gyakorol szignifikáns hatást a PD-re, azaz 30\% alatti PTI nem jelent kockázatot a hitel teljesítô státuszára, a többi viszont minden szokásos szignifikanciaszinten 
3.10. táblázat: Egy átlagos háztartás 10\%-os hosszú távú PD-hez tartozó PTI-je különböző jövedelmek és denomináció mellett (2004-2008)

\begin{tabular}{|l|l|l|l|l|l|}
\hline & $100000 \mathrm{Ft}$ & $150000 \mathrm{Ft}$ & $200000 \mathrm{Ft}$ & $250000 \mathrm{Ft}$ & $300000 \mathrm{Ft}$ \\
\hline Forint & 41 & 45 & 51 & 58 & 69 \\
\hline Deviza & 22 & 24 & 26 & 30 & 35 \\
\hline
\end{tabular}

Megjegyzés: a táblázatban feltüntetett értékek százalékok.

szignifikáns. Ezért - ha nem differenciál a szabályozó hatóság jövedelem és denomináció szerint - 30\%-os PTI választása lehet optimális. Mivel a mintánkban a hitelek nagyobb hányada devizahitel és a háztartások nagy része alacsony jövedelmú, a legtöbb háztartásra az előzô számítás legszigorúbb PTI-előírását kellene alkalmazni, kisebb hányadra vonatkozott volna nagyobb maximális PTI. Így a minta átlagában nagyjából hasonló eredményre jut a kétfajta megközelítés. Utóbbi módszert sajnos nem tudjuk alkalmazni jövedelemkategóriánként és deviza-forint felosztásban, elóbbi esetén ugyanis a magasabb jövedelmúek, utóbbinál pedig a forint hitelek száma kevés a mintában a megfelelő becsléshez.

Az eredményeink szabályozói szempontból fontos üzenetet hordoznak, hiszen ezek szerint azonos PTI-elôrírás a forint- és devizahitelekre előbbi esetében feleslegesen korlátozó, míg utóbbinál túlzottan megengedő lehet. Hasonló mondható el a különböző jövedelmú háztartások egységes szabályozására is. Ezért indokolt differenciáltan kezelni, és különbözô PTI-előírásokat alkalmazni denomináció és háztartási jövedelem szerint. Természetesen a fenti értékek hosszú távon kívánatos, átlagos szintet jelentenek, valamint azt is figyelembe kell vennünk, hogy mintánk a nagy pénzügyi válságot is tartalmazza, ezért némileg enyhébb előírás is elegendô lehet kisebb válságok átvészeléséhez. Amikor a gazdaság és a hitelpiac túlhevülésére utaló jelek tapasztalhatók, az esetleg túlságosan megengedô szabályozásnak, míg recesszió és hitelkontrakció idején a kelleténél szigorúbb PTI-előírások alkalmazásának kockázata magasabb. A szabályozónak ezért érdemes figyelembe venni a gazdasági- és hitelezési ciklus, illetve a kamatok alakulását is. 
3. fejezet. A nemteljesítési valószínúség és az optimális jövedelemarányos törlesztốrészlet-szabály modellezése egy háztartási kérdőíves felmérés felhasználásával

\subsection{A fejezet összegzése}

A hazai háztartások nemteljesítésének valószínűségét egy reprezentatívnak tekinthető kérdőíves felmérés felhasználásával becsültük meg. Az adatok struktúrája keresztmetszeti, bináris változós ökonometriai modellek használatára adott lehetôséget. Célváltozóul a felmérés törlesztési késedelemre vonatkozó kérdését választottuk: nemteljesítônek tekintettük az adott hitelt, ha 90 napon túli elmaradásban volt. A végsố specifikációként kapott modellben a változók előjele és nagyságrendje megfelelt a gazdasági intuícióknak. A modell vintage-hatások és módszertan szempontjából is robusztusnak bizonyult.

A tisztán háztartási jellemzők közül csak a „keresettel rendelkezők aránya” lett szignifikáns, ami a háztartás munkapiaci aktivitását, illetve jövedelmi helyzet szerinti összetételét méri. A becslés szerint, minél több jövedelemmel rendelkezô személy van egy háztartáson belül, annál kisebb a nemfizetôvé válás valószínúsége.

A hitel tulajdonságaira vonatkozóan két változó bizonyult szignifikánsnak a becslésben: egyrészt, a devizahitelek kockázatosabbak a forinthiteleknél, másrészt, a közvetítőkön keresztüli hitelek magasabb nemteljesítési valószínúséggel rendelkeznek a közvetlen banki hitelekhez képest.

Az egyéb mutatók közül további 4 rendelkezett jelentős magyarázó erôvel. A PTI szintje azt méri, hogy a háztartás számára mekkora terhet jelent a hitel visszafizetése, mekkora az eladósodottság mértéke. Minél nagyobb egy háztartás adóssága jövedelmének arányában (PTI), annál nagyobb hitelének hosszú távú PD-je. A becslés alapján növeli egy hitel kockázatosságát az is, ha a háztartásnak további hiteleket is törleszteni kell, ezt a hatást ragadja meg az „egyéb hitelekból származó jövedelemarányos törlesztôrészlet”. A törlesztési képességet nem csak a törlesztôrészletek befolyásolják, így azon háztartások esetében, ahol nagyobb a „törlesztőrészleten felüli kiadások" szintje, ott a nemteljesítés valószínúsége is magasabb. Végül pedig „az egy keresôre jutó törlesztôrészlet” is szignifikánsnak bizonyult, ugyanakkor a változó előjele negatív. Ez azt jelenti, hogy a magasabb törlesztôrészlet alacsonyabb hosszú távú PD-t indukál. Ez a mutató alapvetôen nem az eladósodottságot, hanem sokkal inkább a jövedelmi helyzetet, ezzel párhuzamosan 
a törlesztôrészlet helyett a háztartás számára teljesíthető törlesztőrészletet méri. Ennek fényében viszont érthetô a parciális hatás negatív előjele is.

Számos olyan változót kipróbáltunk a becslések során, amelyek a végsô modellben (inszignifikáns hatásuk miatt) nem jelentek meg, holott empirikus tapasztalatok alapján rendelkezhetnek érdemi magyarázóerôvel. Ezekrôl a változókról azonban bemutattuk, hogy az általuk megjelenített hatást megragadják más, a modellünkben szignifikánsnak bizonyult mutatók. Például hitelcél alapján differenciálva megállapítható, hogy a szabadfelhasználású hitelek sokkal rosszabbul teljesítenek, mint a lakáscélú hitelek. Ez azonban abból fakad, hogy elóbbi esetében a háztartások eladósodottabbak, valamint rosszabb a jövedelmi és a munkapiaci pozíciójuk. Hasonló a helyzet a 2004-2006 és 2007-2008 között kibocsátott hitelek összehasonlításánál: az adósok magasabb eladósodottsága magyarázza a késôbbi időszakban kihelyezett hitelek nagyobb nemteljesítési arányát.

A becsült modell alapján megvizsgáltuk, hogy milyen kapcsolat van a PTI és a nemteljesítési valószínûség között különböző denominációjú hitelek és eltérô háztartási jövedelmek esetén. Az eredmények szabályozói szempontból két fontos üzenetet hordoznak. Azonos PTI-előrírás a forint- és devizahitelekre elóbbi esetében feleslegesen korlátozó, míg utóbbinál túlságosan megengedô lehet. Ennek analógiájára a különbözô jövedelmú háztartások egységes szabályozása is nem kívánt anomáliákhoz vezethet. Ennek elkerülése érdekében egy esetlegesen bevezetendő PTI-szabályozásnál differenciáltan érdemes kezelni a hiteleket denomináció, illetve a háztartásokat jövedelemi szintje szerint. 


\section{4. fejezet}

\section{Banki hatékonyság és piaci erô}

\section{mérése a háztartási és a vállalati}

\section{hitelpiacon}

\subsection{Bevezetés és az irodalom áttekintése}

A bankrendszer hatékonysága és a hitelpiacokra jellemzô verseny indikátorai nagy figyelmet érdemelnek azokban az országokban, ahol a vállalatok pénzügyi forrásait elsôsorban a bankrendszer biztosítja. Hatékonyabb bankrendszer és erôsebb verseny nagyobb pénzügyi mélyülést és alacsonyabb forrásköltségeket eredményez a reálgazdaság számára, így a potenciális GDP növekedését segíti elő. Ugyanakkor a hitelpiacokon a túlzott verseny magas kockázatvállalási hajlandóságot eredményezhet, ami gyengíti a pénzügyi stabilitást és növeli a rendszerszintú pénzügyi válságok kialakulásának valószínúségét. Így szabályozói szempontból ezen indikátorok szintje és változása egyaránt fontos információkat hordoz.

A banki hatékonyság mérésére két modellcsalád létezik: a DEA (data envelopment analysis) és az SFA (stochastic frontier analysis) típusú modellek. A szakirodalomban nem alakult ki konszenzus arról, melyik modellcsalád használata indokoltabb. A DEA-modellek a nemparametrikus becslések közé tartoznak, az elsô 
alkalmazásuk Charnes et al. (1978)-as cikkében történt meg. Ezeknél a modelleknél a hatékony felületet egy lineáris programozási feladatsorozat eredményezi, az ettől való minden eltérést hatékonytalanságként azonosít a modell. Előnyük, hogy a költségfüggvény formájára vonatkozóan nem kell feltételezésekkel élni. A másik modellcsalád használatát két cikk párhuzamosan javasolta először: Aigner et al. (1977), illetve Meeusen és van den Broeck (1977). Az SFA modellek ökonometriai becslésen alapulnak, ahol a hatékony felülettôl való eltérést a modell véletlen hibára és hatékonytalansági tagra bontja. Így ezen modellek elônye, hogy a hatékonytalanság nem maradékként képződik, és véletlen hatások is eltéríthetik a bankokat a hatékony felülettől. Hátránya ugyanakkor, hogy a költségfüggvény formájára és a hibatagok eloszlására vonatkozóan előzetes feltételezésekkel kell élni, amely félrespecifikációt és torzított becslést eredményezhet.

Mivel mindkét módszercsaládnak vannak korlátai és elônyei, gyakran alkalmazzák mindkét megközelítést. A banki hatékonyság becslésének irodalma rendkívül széleskörú, ugyanakkor viszonylag kevés cikk született, amely összehasonlítaná a különbözô becslésekből kapott eredményeket. Az elsô cikk a témában Ferrier és Lovell (1990)-es tanulmánya, amely az USA bankjaira becsül DEA és SFA módszerrel is költséghatékonyságot. Eredményeik szerint, bár a két modell hasonló szintú hatékonytalanságot becsül átlagosan, az egyes bankok hatékonyság szerinti sorrendjében eltérố következtetésekre jutnak. Eisenbeis et al. (1999) szintén amerikai adatokon hasonlították össze a két módszercsaládot, eredményeik ellentétesek a korábbi cikkel: a különbözô módon becsült hatékonyságok szintjükben jelentôsen különböztek, míg a bankok rangsorolása közel hasonló volt a két esetben. Bauer et al. (1998) szintén az USA bankjainak költséghatékonyságát becsülte meg 3 parametrikus (köztük SFA) és DEA modellel. Következtetéseik szerint a parametrikus módszerek átlagosan magasabb költséghatékonyságot becsültek, mint a DEA-modell, miközben az egyes modellek eredményei közötti rangkorreláció nagyon alacsony, és a legrosszabb, illetve a legjobb bankok azonosítása is eltérô megoldásra vezet a különbözô módszerekkel. Továbbá, mindegyik megközelítés idôben viszonylag stabilnak bizonyult, bár a DEA-modell némileg felülteljesítette a parametrikus becsléseket. Ugyanakkor a sztenderd pénzügyi hatékonysági mutatók 
(mint például a múködési költségek és az összes eszköz hányadosa), a parametrikus módszerek becsléseivel mozogtak jobban együtt.

Ázsiai adatokon elóbb Huang és Wang (2002), majd Dong et al. (2014) hasonlították össze a parametrikus és nemparametrikus módszereket. Elóbbi cikk taiwani adatokon arra jutott, hogy átlagos hatékonyságban azonos következtetésre jutnak a modellek, azonban a bankok sorrendje ebben az esetben is nagy mértékben különbözött a két megközelítésben. Utóbbi cikk a kínai bankrendszer adatait használta, és szintén jelentôs eltéréseket talált a parametrikus és nem parametrikus becslések között.

Az európai bankrendszerre némileg ellentmondóak az eredmények, azonban a késôbb készült cikkek következtetései hasonlóak az amerikai és ázsiai tapasztalatokhoz. Drake és Weyman-Jones (1996) brit intézmények esetében, míg Resti (1997) az olasz bankrendszer adatain becsült költséghatékonyságot DEA és SFA modellel is. Ezen cikkek nem találtak jelentôs különbséget a két módszerrel kapott eredmények között sem szintben, sem rangsor tekintetében. A nyugat-európai országok bankjainak hatékonyságát Weill (2004) vizsgálta meg parametrikus és nemparametrikus módszerekkel egyaránt, eredményei szerint a hatékonyság átlagos szintje a különbözô modellek szerint nagyon hasonló, azonban a bankok rangsora különbözô. A cikk vizsgálta a költséghatékonyság és a méret, illetve specializáció kapcsolatát is, a különbözô módszerekkel kapott eredmények ebben az esetben is mutattak eltéréseket. Casu et al. (2004) szintén nyugat-európai bankok esetében vizsgálták a termelékenység javulásának mértékét és okát parametrikus és nemparametrikus modellekkel. Különböző becsléseik rendszerszinten azonos eredményre vezettek, azonban az egyes években más-más tényezőknek tulajdonították a termelékenységjavulást. Delis et al. (2009) görög bankokból álló mintán hasonlították össze a DEA és SFA modellekkel becsült költség-, és profithatékonyságot. Eredményeik szerint a profithatékonyságra, illetve költséghatékonyságra kapott értékek erôsebben korreláltak egymással, mint a DEA és az SFA modellek eredményei.

Kelet-Európai országokra (a szerzők tudomása szerint) még nem készült különbözô modellek eredményeit bemutató összehasonlítás, valamint a profit- és költséghatékonyság esetét is csak Delis et al. (2009) vizsgálták meg kizárólag Görögországra. A feltörekvő európai országokban a kevesebb számú bank, és a felzárkó- 
zás miatti gyorsabb technológiai változások nehezebbé és bizonytalanabbá tehetik a hatékonyságbecslést, ami még inkább indokolja több modell használatát és az eredmények összehasonlítását.

A banki hatékonyság kapcsán a 2008-as pénzügyi válság is felvet fontos kérdéseket: egyrészt, hogy a bankrendszer hatékonysága és a pénzügyi válságok mélysége között van-e kapcsolat, illetve a 2008-as események gyakoroltak-e valamilyen hatást a bankok hatékonyságára. Diallo (2017)-es cikke az elsôre ad választ: becslései alapján a költséghatékonyabb bankrendszereket kisebb mértékben sújtotta a globális válság, a bankok hatékonyságát DEA módszerrel mérte. Nurboja és Kosak (2017) dél-kelet-európai országok adatai alapján pedig megállapították, hogy a válság ösztönözte a bankokat költséghatékonyságuk javítására (utóbbit SFA-modell segítségével számították). Az említett kérdések közül jelen tanulmányban a másodikat vizsgáljuk meg magyar adatokon, nevezetesen: hogyan alakult a bankrendszer hatékonysága a megfigyelt időszakban, illetve a válság hatására történt-e jelentős elmozdulás a rendszerszintű hatékonyságban. Eredményeink szerint a költséghatékonyság kis mértékben bár, de egyértelmúen javult a válság utáni években. Profithatékonyság szempontjából már nem ilyen egységes a kép a különböző modellbecslések alapján: a válság elsô éveiben a modellek stagnálást vagy visszaesést mutattak, majd a kilábalás idôszakában (2013-tól kezdve) javult a profithatékonyság, de nem egyértelmú, hogy meghaladja-e a válság elótti szintet.

A 2008-as válság kitörése a hitelezési veszteségek és a nemteljesítő hitelállomány növekedése miatt is lényeges a költséghatékonyság szempontjából. A bankok nemteljesítő hitelállománya és hitelezési vesztesége a válság kitörését követően a fejlődô és fejlett európai országokban egyaránt jelentôsen megemelkedett, ez az emelkedés azonban érdemi különbségeket mutatott az egyes bankok között, ami a bankok eltérô kockázatvállalási hajlandóságára utalt. Erre a jelenségre reagálva tanulmányunkban az irodalomban szokásosan alkalmazott költségek körét kibôvítettük a hitelezési veszteségekkel, és összehasonlítottuk azon modellek eredményeit, ahol figyelembe vesszük az eltérő kockázatvállalást azokkal, ahol nem.

Jelen fejezetben magyar adatokra becsülünk költség- és profithatékonyságot, DEA és SFA típusú modellekkel egyaránt, majd a Bauer et al. (1998) által javasolt szempontok alapján értékeljük a kapott eredményeket. Számításaink sze- 
rint jelentős eltérés van a két modellcsaládból kapott becslések között, különösen költséghatékonyság esetén. A profithatékonyság-becslések jobban teljesítettek stabilitás és a klasszikus jövedelmezőségi mutatókkal való együttmozgás tekintetében is, mint a költséghatékonyságra vonatkozók. A hitelezési kockázatok figyelmen kívül hagyása során fontos információ veszhet el, ugyanakkor a becslés stabilitását segítheti. A fejezet során a magyar bankrendszer példáján keresztül három fontos szempontra hívjuk fel a figyelmet: (1) a DEA és SFA módszerekból fakadó eredményekből gyakran nem ugyanazokat a következtetéseket lehet leszúrni, így érdemes minél több módszertanra támaszkodni a hatékonysági becslések során, (2) a hitelezési kockázatok figyelembe vétele a hatékonysági becslésekben azok jelentôs nagysága miatt indokolt lehet, (3) a banki hitelállományok heterogenitása a fóbb hitelszegmensek (legalább háztartási - vállalati) modellben történô külön-külön szerepeltetését indokolja.

A magyar bankrendszer költséghatékonyságára vonatkozóan a korábbi tanulmányok nem szolgáltatnak egyértelmú támpontot: a magyar bankok a módszertantól, a becsült idôszaktól és mintától függően hol a KKE-országok élmezônyébe Koutsomanoli-Filippaki et al. (2009), hol azok középmezônyébe Fries és Taci (2005), Nitoi és Spulbar (2015)), hol pedig az európai mezôny hatékonytalanabb felébe Molnár és Holló (2011) kerülnek a becslések szerint. A bankverseny kapcsán pedig a szakirodalom a háztartási és a vállalati hitelszegmens eltéréseiról árulkodik: a korábbi tanulmányok elsôsorban a lakossági hitelpiacon tapasztalható súrlódások-

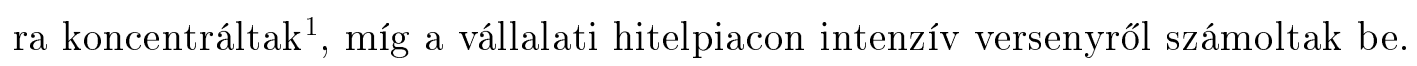

Az SFA-típusú költségfüggvények felhasználásával Lerner-indexet is számítottunk. Becsléseink során külön outputként kezeltük a háztartási, illetve a vállalati hiteleket, mivel azzal a feltételezéssel éltünk, hogy a két hitelpiac eltérô módon múködik.2 A becsült Lerner-indexek ezen várakozásunkat alá is támasztották: a verseny intenzitása szintjében és dinamikájában is különbözött a két szegmensben. Az indexeket kétféleképpen számítottuk ki, a két változat abban különbözött, hogy a kockázati költségeket hogyan vesszük figyelembe. Eszerint nem volt jelentôs el-

\footnotetext{
${ }^{1}$ Lásd például Móré és Nagy (2003), Móré és Nagy (2004), Molnár et al. (2007), illetve Kézdi és Csorba (2012) tanulmányát. Aczél et al. (2016) szintén kiemelik a piaci erô szerepét mint a lakáshitelek felárát magyarázó tényezốt.

${ }^{2}$ Ennek okát részletesen a modellek bemutatásánál fejtjük ki.
} 
térés a becslések között. Végül az újonnan kibocsátott hitelek, valamint a fennálló állomány átlagos kamatlába alapján számított Lerner-indexeket is összehasonlítottuk, ebben az esetben azt találtuk, hogy elóbbiek gyorsabban képesek reagálni a piaci folyamatokra, ezért nagyobb változásokat mutatnak.

A fejezet felépítése a következô: a következókben bemutatjuk a pontos modellspecifikációkat, illetve megindokoljuk miért döntöttünk ezen feltételezések mellett, majd a felhasznált adatokról adunk rövid leírást. Ezután részletesen tárgyaljuk a kapott eredményeket, végül az utolsó részben összegezzük a legfontosabb következtetéseinket.

\subsection{Adatok és módszertan}

A DEA és az SFA típusú modellek esetén is számos lehetséges modellspecifikáció áll rendelkezésre, amelyek lényegüket tekintve megegyeznek, bizonyos részfeltételezéseikben azonban különböznek egymástól. A konkrét modellspecifikációk kiválasztásánál törekedtünk arra, hogy egyrészt feltételezéseink minél inkább egybeessenek a bankrendszer ismert tulajdonságaival, másrészt az összehasonlíthatóság miatt a DEA és az SFA modelleink feltételei, ahol lehetséges, megegyezőek legyenek.

A bankok hatékonyságának kiszámítása során minden megközelítésben a termelési folyamatot modellezzük, azaz azt vizsgáljuk, hogy bizonyos inputokból, adott inputárak mellett mennyi outputot sikerült előállítani, összességében mekkora költségráfordítással vagy nyereséggel. Inputként a banki hatékonyság vizsgálatánál a humán erôforrást és a tárgyi eszközöket mindenképpen figyelembe szokás venni. Outputként a hitelállomány és a kamatozó eszközök vagy az összes egyéb eszköz szokott minden esetben szerepelni. Általában a modellek háromnál több inputot vagy outputot nem tartalmaznak, ezek száma csak bizonyos korlátok között növelhető 3

\footnotetext{
${ }^{3} \mathrm{Az}$ SFA modellek esetében ennek valószínúleg az az oka, hogy túl sok magyarázóváltozó kerülne be a becslésbe, ami jelentôsen megnövelné a bizonytalanságát. DEA modelleknél pedig túl sok üzleti modellt lehetne így hatékonynak tekinteni.
} 
Ahogy már korábban említettük, külön vizsgáltuk a profit- és költséghatékonyságot. Miért különbözhet a kettô eredménye? A profithatékonyság vizsgálatának szükségességét a modellbe illesztett outputok heterogenitása indokolja, amely számos okból fennállhat. Példának okáért a hitelállomány (amely rendszerint homogén termékként szerepel a költséghatékonysági becslésekben) több szempontból is heterogénnek tekinthető. Ezt a heterogenitást okozhatja többek között az esetleges lejárati különbség a hitelállományokban. Ha egy bank nagyobb arányban bocsát ki rövidebb hiteleket, a hitelek gyorsabb forgási sebessége következtében magasabbak lesznek a költségei is, így költséghatékonyságban rosszabb lesz, mint a többi bank. Ugyanakkor a rövid lejáratú hitelek kamatai általában magasabbak, így e bank bevételei is magasabbak lesznek, ezért összességében profithatékonyságban akár jobban is teljesíthet a piac egyéb szereplőinél. Szintén a hitelállomány homogénnek tekintése vezet ahhoz a problémához, hogy a teljesítô és nemteljesítő állományt egységesen kezelik a modellek. Különösen pénzügyi válságok esetében, amikor a nemteljesítô állomány megemelkedik és nagymértékben különbözhet az egyes intézményeknél, ez jelentôsen befolyásolhatja az eredményeket. Ennek oka, hogy egy ilyen portfoliónak a jövedelemtermelő képessége gyengébb, mint a többi hitelnek, miközben általában magasabb múködési költségeket is maga után von. Szintén sérti a homogenitást az egyes hiteltermékek eltérő költségvonzata: a háztartási hitelezésben például érdemben eltérhet egy jelzáloghitel és egy fedezetlen fogyasztási hitel folyósításának költsége, amit a bank az árazásban - tehát a profitban - érvényesít.Tehát, ha az egyes bankok eltérô szegmensekre specializálódnak, és a költségfüggvényben túl kevés outputot definiálunk, úgy mind a DEA, mind az SFA módszerek hatékonytalanságot mutathatnak ki olyan esetekben is, amikor a költségek egyes intézményeknél megfigyelhetô alacsonyabb vagy magasabb szintje egyszerúen az eszközök eltérô összetételébôl fakad. Ugyanakkor a költséghatékonyság mellett is szólnak érvek: a profithatékonyságot nagyobb mértékben befolyásolják a ciklikus reálgazdasági események, mivel ezek a profitot a kockázatokon és a kamatbevételeken keresztül is érintik. A termelékenység javulását tehát a költséghatékonyság jobban ragadhatja meg.

Outputok tekintetében végül három termék mellett döntöttünk: a modellben a háztartási hiteleket, a vállalati hiteleket és az egyéb kamatozó eszközöket szerepel- 
tetjük. Elméleti szempontból a két hitelpiac ráfordításokban, belépési korlátokban és a fogyasztók viselkedésében különbözhet jelentôsen. A háztartási hitelpiacon ugyanaz az állomány átlagosan nagyobb fiókhálózat és személyi állomány fenntartását teszi szükségessé, mint a vállalati hitelpiacon, ahol nagyobb a hitelméret. A szükséges fiókhálózat kiépítése egyben nagyobb belépési korlátot is jelent a háztartási hitelek piacán, amelyet tovább erôsít, hogy kevésbé racionális vagy kevésbé informált, és a piac méretéhez képest kisebb fogyasztók jellemzik, mint a vállalati hitelpiacot $]^{4}$ További különbséget jelent a két szegmens között az információs aszimmetria eltérô szintje: míg a vállalati hitelpiacon a bankoknak lehetôségük van a vállalat pénzügyi kimutatásaiból tájékozódni a hitelfelvételt megelőzően és azt követően is, a lakossági hitelpiacról ugyanez csak korlátozottan mondható el, fôleg a futamidô késóbbi éveiben

További árazási könnyebbséget jelentett a bankoknak a magyar háztartási hitelpiacon a változtatható kamatozású hitelkonstrukciók magas aránya szemben a vállalati hitelpiaccal, ahol a változó kamatozású hitelek domináltak. A magyar jogszabályi környezet 2012 elôtt ugyanis meglehetôsen megengedô volt a hitelfeltételek futamidô közbeni módosításával kapcsolatban, így a bankok olyan jogi megoldásokat alakíthattak ki, amely lehetôséget biztosított számukra a futamidố során a kamatláb egyoldalú megemelésére. A legtöbb intézmény élt is ezzel a lehetôséggel, így a válság kitörését követően a már kifolyósított lakossági hitelek kamatlába átlagosan 150-200 bázisponttal emelkedett. A vállalati hitelek esetében nem terjedt el ez a konstrukció, ami egyrészt a szektor jobb alkupozíciójának, másrészt a rövidebb futamidőknek köszönhetô. A két hitelszegmens közötti markáns eltéréseket a késôbbiekben Lerner-index számításával is teszteljük. Az említett különbségek

\footnotetext{
${ }^{4}$ Ennek tükrében nem véletlen, hogy a KKE országokban a Szovjetunió összeomlását követôen megjelenô külföldi bankok több esetben is a vállalati hitelezésre specializálódtak, és sok esetben a „home” országban is jelenlévố multinacionális vállalatokat követték a régióba Havrylchyk (2006). A külföldi bankok Magyarországon is éveken keresztül lemaradásban voltak a háztartások hitelezésében a nagyon mély beágyazottsággal bíró OTP-hez képest, ami szintén elóbbi intézmények versenyhátrányát és az e szegmensre jellemzô magasabb belépési költségeket mutatja.

${ }^{5}$ Bár a szerzốdéskötéskor rendszerint a lakossági hitelek esetében is igazolnia kell az ügyfélnek jövedelmi és vagyoni helyzetét, a futamidô késôbbi éveiben a lakossági adós pénzügyi helyzetének változása sokkal kevésbé követhetô és ellenốrizhetô, mint a vállalati hitelek esetében, ahol rendszeres számviteli kimutatások állnak rendelkezésre.
} 
egyben azt is indokolttá teszik, hogy a hatékonyság becslésénél figyelembe vegyük a hitelállomány heterogenitását.

A bankrendszert szokás pénzügyi közvetítóként és pénzteremtôként is modellezni. Előbbi esetben az inputok között megjelennek a pénzügyi források is, míg utóbbi feltételezésnél az outputok között szerepelnek a betétek is. Mivel egyrészt a magyar bankrendszer nagy mértékben támaszkodik külföldi forrásokra, másrészt a hitelállomány megbontásával már így is három outputot szerepeltettünk, a pénzügyi közvetítô megközelítés mellett döntöttünk.

Mindkét modelltípusnál megkötésekkel lehet élni a mérethozadékra vonatkozóan (ha van kikötés, az általában konstans mérethozadékot feltételez). Mivel egy feltörekvő ország bankrendszerét vizsgáltuk, amely a megfigyelt időszakban több strukturális törést is elszenvedett, ráadásul az eszközök piacán a hosszú lejáratok miatt lassú az alkalmazkodás, így érdemi piaci súrlódásokkal is számolni kell, ezért változó mérethozadékot feltételeztünk

A hitelezési veszteségeket ezek a modellek általában nem szokták figyelembe venni, noha a bankok számára rendszeres és érdemi kiadási tételek, nagyságuk nem elhanyagolható a múködési költségekhez képest. Ugyanakkor üzleti (könyvelési) döntések és ciklikus események erősen befolyásolhatják a képzendő értékvesztést. Mivel mintánk egy válságperiódust is tartalmazott, amikor a hitelezési veszteségek különösen magasak is lehetnek, ezért fontosnak tartottuk a modellekben expliciten megjeleníteni ezeket a költségeket 4.1 es ábra). Ez az eljárás nem szokványos a szakirodalomban és nem is egyértelmú, milyen módon érdemes a modellekbe beépíteni ezeket az információkat. A konkrét modellek bemutatásánál térünk ki ezek pontos megvalósítására.

\subsubsection{Az SFA modellek}

Az SFA modellek esetében a teljes költség vagy teljes profit függvény a következőképpen írható fel:

\footnotetext{
${ }^{6}$ Ezt a feltételezést is teszteltük, a konkrét modellek bemutatásnál fogunk erre bôvebben kitérni.
} 
4.1. ábra: Az értékvesztés eredményrontó hatása az összes eszköz arányában az EU országaiban

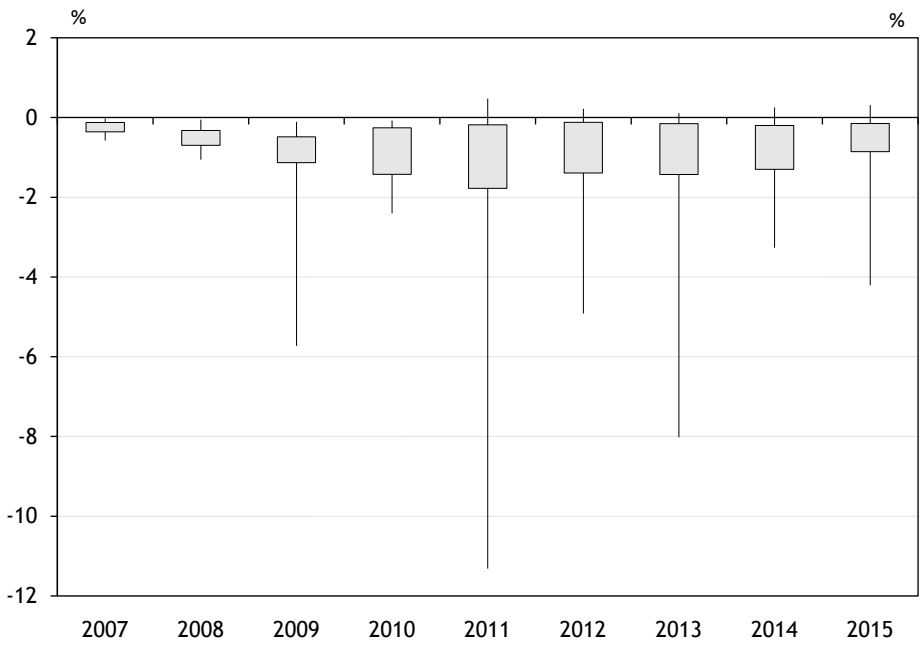

Megjegyzés: az ábrán az értékvesztés eredményrontó hatásának adott évi minimuma és maximuma, valamint 25. és 75 . percentilise látható. Az egyes években az elérhetó adatok tükrében nem minden ország adatait tudtuk figyelembe venni. Forrás: EKB Consolidated Banking Data.

$$
T C_{i t}=C\left(Y_{i t}, W_{i t}, Z_{i t}, u_{i t}, e_{i t}\right)
$$

ahol $T C_{i t}$ jelöli az $i$-edik bank összes költségét vagy összes profitját a $t$-edik idôszakban. $Y_{i t}$ az outputok, $W_{i t}$ az inputárak, $Z_{i t}$ a további kontrollváltozók vektora az $i$-edik bank esetén a $t$-edik periódusban. $u_{i t}$ jeleníti meg a bankok eltérését a hatékony felülettól, $e_{i t}$ pedig az egyedi véletlen hatásokat. Az egyenletet logaritmizált formában becsüljük meg, azaz:

$$
\ln T C_{i t}=c\left(Y_{i t}, W_{i t}, Z_{i t}\right)+\ln u_{i t}+\ln e_{i t},
$$

amelyból $l n u_{i t}$ mutatja az eltérést a hatékony felülettól, ezért értéke költségfüggvény esetén mindig nemnegatív, míg profitfüggvénnyel számolva nempozitív, lne $e_{i t}$ pedig normális eloszlású véletlen zaj. 
Az egyenlet megbecsléséhez legalább két további feltételre van szükségünk: a költségfüggvény $(c)$ pontos formájára és a hatékonytalansági tag eloszlására. Ezen felül léteznek olyan becslések, ahol meg lehet adni $u_{i t}$-t identifikáló konkrét változókat is (például: Greene (2005)), ezzel azonban két okból nem éltünk: egyrészt nem akartunk további megkötésekkel élni, másrészt annak érdekében, hogy eredményeink a DEA modellekkel is összehasonlíthatóak legyenek. A költségfüggvényre vonatkozóan a szakirodalomban legelterjedtebb transzlog típusú függvényformát, míg $u_{i t}$ kapcsán exponenciális eloszlást feltételeztünk. A becsült egyenletünk tehát a következô:

$$
\begin{aligned}
\ln T C_{i t}= & \alpha_{0}+\Sigma_{j} \beta_{j} \ln Y_{j t}+\Sigma_{k} \gamma_{k} \ln W_{k t}+\frac{1}{2} \Sigma_{j} \Sigma_{l} \delta_{j l} \ln Y_{j t} \ln Y_{l t}+ \\
& +\frac{1}{2} \Sigma_{k} \Sigma_{m} \omega_{k m} \ln W_{k t} \ln W_{m t}+\Sigma_{j} \Sigma_{k} \nu_{j k} \ln Y_{j t} \ln W_{k t} \\
& +\Sigma_{s} \mu_{s} \ln Z_{s t}+\ln u_{i t}+\ln e_{i t} .
\end{aligned}
$$

Az együtthatókat és a maradéktagokat maximum likelihood becslés során kaptuk meg, követve Wang (2002) becslési módszerét. Azon becslések esetén, ahol a háztartási, illetve a vállalati értékvesztés is szerepelt a modellben inputárként, az értékvesztésekhez tartozó keresztszorzatok közül csak a hitelállománnyal vett keresztszorzatokat vettük figyelembe, mivel a két új inputárváltozó felvétele nagyon megnövelte volna a becsült paraméterek számát.

\subsubsection{A DEA modellek}

A DEA modellek egy lineáris programozási feladat formájában fogalmazzák meg a bankok költségminimalizálási vagy profitmaximalizálási problémáját. A klasszikus, konstans mérethozadékot feltételező modell felírása egy adott bankraㄱ.

\footnotetext{
${ }^{7}$ A DEA modellekról hosszabb, intuitívabb magyarázatot tartalmaz a Függelék.
} 


$$
\min _{\lambda, x_{i 0}^{*}} \sum_{i=1}^{m} w_{i o} x_{i 0}^{*}
$$

$$
\begin{aligned}
& \text { Feltéve, hogy } \sum_{j=1}^{n} \lambda_{j} y_{r j}-y_{r 0} \geq 0, \quad r=1, \ldots, s \\
& \sum_{j=1}^{n} \lambda_{j} x_{i j}-x_{i 0} * \leq 0, \quad i=1, \ldots, m \\
& \lambda_{j} \geq 0, \quad j=1, \ldots, n
\end{aligned}
$$

Ahol $n$ jelöli a bankok, $s$ az outputok, $m$ az inputok számát, $x_{i 0}^{*}$ az inputok költségminimalizáló vektora adott inputárak $\left(w_{i 0}\right)$ és outputszintek $\left(y_{r 0}\right)$ mellett. Az optimális vektor így azon bankok inputjainak lineáris kombinációja, akik legalább annyi outputot termelnek, mint az adott bank, de nem több input felhasználásával. A kiértékelt bank hatékonyságát úgy lehet kiszámolni, hogy a valós költségszintjét hasonlítjuk az optimális költségszinthez, azaz: a $j$-edik bank hatékonysága: $w_{i j} x_{i j}^{*} / w_{i j} x_{i j}$. Így a hatékony felülettôl való eltérés: $1-w_{i j} x_{i j}^{*} / w_{i j} x_{i j}$, amelynek értéke a teljesen hatékony bankoknál 0. A profithatékonyság esetén előfordult, hogy bizonyos bankok negatív profitot értek el egyes években, ezekben az esetekben a mutató értékét 1-nek tekintettük. A feladat megfogalmazásából következôen a mintában mindig lesz egy teljesen hatékony bank.

Ahogy már korábban említettük, konstans mérethozadék helyett változó mérethozadékot feltételeztünk, ezért a feladat kiegészült a súlyokkal kapcsolatban egy további feltétellel: $\sum_{j=1}^{n} \lambda_{j}=1$. A (4.4)-es egyenletrendszer során azzal a feltételezéssel éltünk, hogy az inputárak minden bank számára egységesen adottak. Ez különösen a forrásköltségek szempontjából megkérdőjelezhető feltétel, mivel például a külföldi tulajdonban lévô vagy a kedvezôbb szolvenciahelyzetben lévô bankok olcsóbban szerezhetnek forrásokat. Ezért Tone (2002)-es javaslata szerint módosítottuk a modellt, eszerint minden bank egyedi inputárakkal szembesül, és az inputárak bekerültek az inputokra vonatkozó egyenlótlenségi feltételekbe. Továbbá, a hitelállományok értékvesztését és az SFA modelleknél alkalmazott kontrollváltozókat is beépítettük a DEA modelljeinkbe is, mégpedig kvázifix költségekként. Gulati és Kumar (2016)--os modelljéhez hasonlóan a kvázifix költségekre is ugyanúgy kell 
teljesülnie egy egyenlőtlenségnek, mint a többi költség esetén, előbbiek azonban a célfüggvényben nem jelennek meg és nem döntési változók. Így összességében a költséghatékonyságot becslő modellünk a (4.5)-ös optimalizálási feladattal írható le. A hatékonyságot ezúttal is az optimális és a tényleges költségek hányadosaként kapjuk.

A profithatékonyság felírása azonos logikán alapul, és a feltevései is - egy kivétellel - megegyeznek a költséghatékonyságra vonatkozó feladattal. Az egy kivétel az, hogy az outputokra vonatkozó korlátokat egy, a bevételekre vonatkozó korlát helyettesíti. A $j$-edik bank bevételeit $R_{j}$ jelöli (4.6).

Végül, még egy feltételezést tenni kell a modell megbecsléséhez: időben állandónak vagy változónak tekintjük-e a hatékony felületet. Amennyiben utóbbi mellett döntünk, az $n$ paraméter valóban a bankok számát jelöli, és minden egyes periódusra külön kell lefuttatnunk az optimalizálásokat. Ha azonban azt feltételezzük, hogy a technológia a megfigyelt idôszakban végig állandó volt az $n$ index valójában a bankok számának és a periódusok számának a szorzata, ebben az esetben az optimalizálásokat egyszerre végezzük el. (A ténylegesen lefuttatott lineáris programozási feladatok számán ez a feltétel nem változtat, azon viszont igen, hogy a bankok hány megfigyelését vesszük figyelembe egy feladat során.)

$$
\begin{gathered}
\min _{\lambda, x_{i 0}^{*}} \sum_{i=1}^{m} w_{i o} x_{i 0}^{*} \\
\text { Feltéve, hogy } \sum_{i=1}^{n} \lambda_{j} y_{r j}-y_{r 0} \geq 0, \quad r=1, \ldots, s \\
\sum_{j=1}^{n} \lambda_{j} w_{i j} x_{i j}-w_{i 0} x_{i 0}^{*} \leq 0, \quad i=1, \ldots, m \\
\sum_{j=1}^{n} \lambda_{j} z_{k j}-z_{k 0} \leq 0, \quad k=1, \ldots, p \\
\sum_{j=1}^{n} \lambda_{j}=1, \quad \\
\lambda_{j} \geq 0, \quad j=1, \ldots, n
\end{gathered}
$$




$$
\max _{\lambda, x_{i 0}^{*}, R_{0}^{*}} R_{0}^{*}-\sum_{i=1}^{m} w_{i o} x_{i 0}^{*}
$$

Feltéve, hogy $\sum_{j=1}^{n} \lambda_{j} w_{i j} x_{i j}-w_{i 0} x_{i 0}^{*} \leq 0, \quad i=1, \ldots, m$

$$
\begin{aligned}
\sum_{j=1}^{n} \lambda_{j} z_{k j}-z_{k 0} & \leq 0, \quad k=1, \ldots, p \\
\sum_{j=1}^{n} \lambda_{j} R_{j}-R_{0}^{*} & \geq 0 \\
\sum_{j=1}^{n} \lambda_{j} & =1, \\
x_{i 0} & \geq x_{i 0}^{*}, \quad i=1, \ldots, m \\
R_{0} & \leq R_{0}^{*}, \quad \\
\lambda_{j} & \geq 0, \quad j=1, \ldots, n
\end{aligned}
$$

Utóbbi mellett szóló érv, hogy kevés bank esetén a sok feltétel miatt túl sok bankra jöhet ki, hogy nagyon hatékony. Elóbbi megközelítést erôsíti, hogy a DEA modellek nem veszik figyelembe a bankokat érő véletlen sokkokat, ezért ebben a szemléletben könnyen változhat minden évben a technológia. Mi végül egy köztes megoldás mellett döntöttünk: négy részre osztottuk a mintánkat, az almintákon belül az egyes években a bankrendszer múködési környezete nagyjából azonos volt. Az elsô időszak 2001-tôl 2004-ig tart, amikor is kiegyensúlyozott növekedés és forintban denominált hitelek jellemezték a magyar bankrendszert. 2005-2008 a túlzott hitelezés és a devizában történô eladósodás periódusa, 2009-2012 a válság legnagyobb visszaesést hozó évei, 2013-2016 pedig a kilábalás időszaka.

A mérethozadékra vonatkozóan tehát, ha a $\lambda_{j}$-k összegére nem teszünk megkötést, akkor konstans mérethozadékot feltételezünk, ha azt kötjük ki, hogy $0 \leq$ $\sum_{j=1}^{n} \lambda_{j} \leq 1$, akkor a mérethozadék nemnövekvô. Ha a $\lambda_{j}$-knek 1-re kell összegződni, akkor pedig változó mérethozadékú a technológia. Megbecsültük modelljeinket az enyhébb feltételekkel is, és megvizsgáltuk, hogy a különböző esetekben az optimális eredmények egybe esnek-e. Mivel a megoldások jelentôsen különböztek mindkét 
enyhébb megkötés esetében, ezért a változó mérethozadék feltételezése mellett maradtunk, és az SFA modelleknél is ezt a feltételt alkalmaztuk.

\subsubsection{Adatok}

A becsléshez egy 12 bank adatait 2001 és 2016 között tartalmazó, kiegyensúlyozott paneladatbázist használtunk. A mintában olyan bankokat szerepeltettünk, amelyek (1) 2001 óta folyamatosan múködnek és (2) múködésük piaci alapon történik (tehát a speciális állami feladatot ellátó bankokat, mint a Magyar Fejlesztési Bank és az EXIM Bank nem szerepeltetjük a mintában)..$^{8}$ Az adatokat éves frekvencián vizsgáltuk, így összesen 192 megfigyelésünk volt a mintában. Az adatok tekintetében a Magyar Nemzeti Bank által gyưjtött statisztikákra (azon belül is elsôsorban a mérleg- és eredménykimutatás, valamint kamatstatisztikákra) támaszkodtunk. A mintánk az ideálisnál kevesebb megfigyelést tartalmaz, azonban az elérhetô adatok tükrében annak kibővítése csak részlegesen és bizonyos áldozatok mellett lenne lehetséges..$^{9}$

A költséghatékonysági becslésekhez - ahogy korábban is említettük - három outputot definiáltunk: a háztartási hiteleket, a vállalati hiteleket és az egyéb kamatozó eszközöket. A háztartási hitelek jelentôs részben a lakosság számára nyújtott hiteleket (jelzáloghitelek, fedezetlen fogyasztási hitelek) tartalmazzák. A vállalati hitelek között mind nagyvállalati, mind kkv hitelek szerepelnek. Az egyéb kamatozó eszközök között a legjelentôsebb részt az államkötvények és a jegybank által kibocsátott instrumentumok képviselik, míg kisebb részben az egyéb szektoroknak

\footnotetext{
${ }^{8}$ A mintában szereplố bankok/bankcsoportok a következók: Budapest Bank, CIB Bank, Erste Bank, FHB Bank, K\&H Bank, MKB Bank, Volksbank/ Sberbank, OTP Bank, Raiffeisen Bank, UniCredit Bank, Fundamenta és KDB Bank.

${ }^{9}$ A minta időbeli dimenziójának bôvítése negyedéves frekvencia alkalmazásával lenne lehetséges, azonban a banki müködés sajátos jellege miatt (például a jellemzóen év végén megképzett értékvesztések, vagy éven belüli pénzpiaci tranzakciók negyedéveken átívelő, ellentétes előjelű eredményhatása miatt) ezzel igen jelentôs éven belüli zajt vinnénk az idôsorokba. A minta keresztmetszeti szempontból is bővíthetô lenne további intézményekkel, azonban ezek jellemzően egy-egy szúk piacon múködő, speciális intézmények, így a költséghatékonysági becslésekben outlierként jelennének meg.
} 
(pl. önkormányzatok) folyósított hitelek is idetartoznak. Az inputok és inputárak a szakirodalomban megszokott formában szerepelnek a modellben. Inputként szerepelnek a kamatozó források (áruk a kamatkiadások és a kamatozó források hányadosa), a személyi jellegú költségek (áruk a személyi jellegú költségek mérlegföösszeghez viszonyított aránya) és az anyagi jellegú ráfordítások, ideértve az amortizációt is (melyek ára a ráfordítások és a bank saját eszközeinek hányadosaként adódik). A hitelezési veszteségek input a bankok nettó értékvesztés elszámolásának és az áron alul eladott követelések eredményhatását egyaránt tartalmazza. ${ }^{10}$ A célváltozó a költséghatékonysági becslések esetében a múködési költségek és a kamatkiadások összege, míg a profithatékonysági modellek esetében az eredményváltozónk a nettó kamatbevételek és a nettó díj- és jutalékbevételek összege csökkentve a múködési költségek nagyságával. Azon becslések esetén, amelyeknél a hitelezési veszteségeket is figyelembe vettük, az eredményváltozókhoz is hozzá adtuk az értékvesztés eredményrontó hatását.

A Lerner-index becsléséhez háromféle árjellegú változót alkalmaztunk. A szakirodalomban szokásos kamatbevétel / kamatozó eszköz hányados mellett lehetôségünk nyílt az indexet újonnan szerződött hitelek átlagos kamatlábával (illetve a háztartási szegmens esetében teljes hitelköltséggel), valamint a fennálló hitelek állománnyal súlyozott átlagos kamatlábával is kiszámolni. Az utóbbi két árjellegú változó alkalmazása nem megszokott a szakirodalomban, amelynek legfóbb oka az, hogy ezeket a statisztikákat a jegybankok rendszerint csak szektorszinten publikálják. Ugyanez igaz az előbbi mutatók hitelszegmens szerinti megbontására is: a háztartási és vállalati kamatbevételek/kamatlábak nagysága meglehetôsen ritkán elérhetô publikus adatforrásokból.

\subsection{Eredmények}

Az SFA modellek megbecslésekor a lehetséges kontrollváltozók közül nem minden kontrollváltozó került be végül az egyes becslésekbe. Az úgynevezett lambdastatisztika, amely a kétfajta hibatag szórásának hányadosaként adódik fontos jele

\footnotetext{
${ }^{10} \mathrm{Az}$ adatok részletes leírását és a képzett mutatók számításának módját a Függelék $5.10,5.11$ 5.12 es táblázata tartalmazza.
} 
4. fejezet. Banki hatékonyság és piaci erố mérése a háztartási és a vállalati hitelpiacon

4.1. táblázat: A hatékonytalanságok leíró statisztikái (teljes minta)

\begin{tabular}{|l|l|l|l|l|l|l|l|l|}
\hline & DEA & DEA & DEA & DEA & SFA & SFA & SFA & SFA \\
\hline & $\begin{array}{l}\text { Profit } \\
\text { érték- } \\
\text { vesz- } \\
\text { téssel }\end{array}$ & $\begin{array}{l}\text { Költség } \\
\text { érték- } \\
\text { vesz- } \\
\text { téssel }\end{array}$ & Profit & Költség & $\begin{array}{l}\text { Profit } \\
\text { érték- } \\
\text { vesz- } \\
\text { téssel }\end{array}$ & $\begin{array}{l}\text { Költség } \\
\text { érték- } \\
\text { vesz- } \\
\text { téssel }\end{array}$ & Profit & Költség \\
\hline Átlag & 0,39 & 0,08 & 0,59 & 0,21 & 0,18 & 0,08 & 0,40 & 0,03 \\
\hline Medián & 0,32 & 0,00 & 0,70 & 0,06 & 0,10 & 0,02 & 0,26 & 0,03 \\
\hline Min & 0,00 & 0,00 & 0,00 & 0,00 & 0,02 & 0,01 & 0,03 & 0,01 \\
\hline Max & 1,00 & 0,71 & 1,00 & 0,77 & 1,00 & 0,16 & 1,00 & 0,16 \\
\hline Szórás & 0,39 & 0,17 & 0,35 & 0,24 & 0,19 & 0,01 & 0,32 & 0,03 \\
\hline
\end{tabular}

a rossz specifikációnak. Ezért azokat a kontrollváltozókat vettük be a becslésbe, amelyek esetén ez a statisztika nagyságrendileg 1-hez közeli értéket vett fel (lásd: Függelék 5.17, 5.18, 5.19, 5.20-as táblázat). Így a profitfüggvények esetén a tőkepufferek nagysága, a költségfüggvényeknél pedig szintén a tôkepufferek, valamint a likvid eszközök aránya és a bankfiókok száma szerepel még a modellben. A DEA modelleknél a kvázifix költségként szereplő változók köre megegyezik az ugyanazon típusú SFA becsléseknél alkalmazott kontrollváltozókkal.11

\subsubsection{Az SFA és a DEA modellek eredményeinek összehason- lítása}

Követve Bauer et al. (1998), valamint Dong et al. (2014) eljárását, 5 lépésben elemezzük a modellek eredményei közötti kapcsolatot és értékeljük a becsléseket. Elsô lépésben a hatékonytalansági paraméterek leíró statisztikáit vetjük össze 4.1 es táblázat).

\footnotetext{
${ }^{11} \mathrm{~A}$ regressziók becslési outputjai megtalálhatók a Függelékben: $5.13,5.14,5.15,5.16$ os táblázat.
} 
Az átlag és a medián alapján is mindkét modellcsalád magas költséghatékonyságot és lényegesen alacsonyabb profithatékonyságot talált. Érdekes, hogy az értékvesztéssel is számoló, DEA-típusú költséghatékonyságnál a medián is nulla, ami azt jelenti, hogy a modell szerint a bankrendszer legalább fele teljesen hatékony. A hatékonytalanságok eloszlása általában enyhén vagy erôsebben balra ferdült (kivétel az értékvesztéssel nem számoló DEA-s profitfüggvény), amely arra utal, hogy elsôsorban a rosszabb teljesítmény irányába mutatnak kiugrást az eloszlások. Minimumok tekintetében az SFA modellek semelyik bankot nem tekintik teljesen hatékonynak, míg a DEA modellek esetében ilyen minden esetben létezik. A megfigyelt maximális hatékonytalanságok esetében a profitfüggvények jelzik a leghatékonytalanabb bankokat, költségfüggvények tekintetében ugyanakkor a hatékonytalanságok terjedelme a DEA-modelleknél sokkal nagyobb. A szórásértékek a magasabb maximumokból fakadóan nagyobbak a DEA modelleknél, mind profit-, mind költséghatékonyság tekintetében. A momentumok alapján tehát azt a következtetést vonhatjuk el, hogy szélsôséges hatékonysági értékek kimutatására a DEA modellek hajlamosabbak, valamint költséghatékonyság szempontjából a bankrendszer homogénebb, mint a profithatékonyság esetén.

A második vizsgálati szempont a korrelációk és rangkorrelációk összevetése 4.2 . es táblázat). Eredményeink a szakirodalom azon részéhez tartoznak, amelyek gyenge kapcsolatot mutatnak ki a két fajta becslési eljárás között. A 16-16 lehetséges korreláció és rangkorreláció közül 2, illetve 3 esetben kaptunk 1 százalékon is szignifikáns, pozitív korrelációt. Modellcsaládon belül a DEA eredmények (minden szokásos szignifikanciaszinten) közepesen korreláltak, míg az SFA modellek esetében jelentôs eltérést mutatnak a költség- és profithatékonyságra vonatkozó becslések. Ugyanakkor a legerôsebb korreláció az SFA modelleken belül van, az értékvesztés figyelembevétele vagy elhagyása esetén kapott becsléseknél jelentkeztek a legkisebb eltérések. Ezért összességében azt lehet elmondani, hogy a DEA-modellek bizonyultak robusztusabbnak a konkrét modellspecifikációra, de kis eltérések az SFA modellek eredményein csak kis mértékben változtatnak. Továbbá, a profithatékonyságra vonatkozó eredmények a két modellcsalád (DEA-SFA) között is mutattak szignifikáns, pozitív korrelációt, míg költséghatékonyság esetén ez nem volt 
4. fejezet. Banki hatékonyság és piaci erố mérése a háztartási és a vállalati hitelpiacon

4.2. táblázat: A hatékonytalanságok korrelációja és Spearman-féle korrelációja

\begin{tabular}{|c|c|c|c|c|c|c|c|c|c|}
\hline & & DEA & & & & SFA & & & \\
\hline & & $\begin{array}{l}\text { Profit } \\
\text { érték- } \\
\text { vesz- } \\
\text { téssel }\end{array}$ & $\begin{array}{l}\text { Költség } \\
\text { érték- } \\
\text { vesz- } \\
\text { téssel }\end{array}$ & Profit & Költség & $\begin{array}{l}\text { Profit } \\
\text { érték- } \\
\text { vesz- } \\
\text { téssel }\end{array}$ & $\begin{array}{l}\text { Költség } \\
\text { érték- } \\
\text { vesz- } \\
\text { téssel }\end{array}$ & Profit & Költség \\
\hline \multirow[t]{4}{*}{ DEA } & $\begin{array}{l}\text { Profit } \\
\text { érték- } \\
\text { vesz- } \\
\text { téssel }\end{array}$ & $1,00^{* *}$ & $0,50^{* *}$ & $0,62^{* *}$ & $0,48^{* *}$ & $0,25^{*}$ & $-0,21^{*}$ & $0,40 * *$ & $-0,19^{*}$ \\
\hline & $\begin{array}{l}\text { Költség } \\
\text { érték- } \\
\text { vesz- } \\
\text { téssel }\end{array}$ & $0,45^{* *}$ & $1,00^{* *}$ & $0,32^{* *}$ & $0,69^{* *}$ & $-0,01$ & $-0,15^{*}$ & $0,19^{*}$ & $-0,17^{*}$ \\
\hline & Profit & $0,63^{* *}$ & $0,26^{* *}$ & $1,00^{* *}$ & $0,50 * *$ & $0,21^{*}$ & $-0,18^{*}$ & 0,34 & $-0,14$ \\
\hline & Költség & $0,48^{* *}$ & $0,60^{* *}$ & $0,45^{* *}$ & $1,00^{* *}$ & $-0,08$ & $-0,18^{*}$ & 0,08 & $-0,21^{*}$ \\
\hline \multirow[t]{4}{*}{ SFA } & $\begin{array}{l}\text { Profit } \\
\text { érték- } \\
\text { vesz- } \\
\text { téssel }\end{array}$ & $0,25^{* *}$ & 0,06 & 0,16 & $-0,09$ & $1,00 * *$ & $-0,16^{*}$ & $0,71^{* *}$ & $-0,12$ \\
\hline & $\begin{array}{l}\text { Költség } \\
\text { érték- } \\
\text { vesz- } \\
\text { téssel }\end{array}$ & $-0,18^{*}$ & $-0,09$ & $-0,15^{*}$ & 0,14 & $-0,22^{*}$ & $1,00 * *$ & $-0,18^{*}$ & $0,55^{* *}$ \\
\hline & Profit & $0,36^{* *}$ & 0,13 & $0,36^{* *}$ & 0,05 & $0,78^{* *}$ & $-0,23^{*}$ & $1,00^{* *}$ & $-0,15^{*}$ \\
\hline & Költség & $-0,18^{*}$ & $-0,14$ & $-0,08$ & $-0,14$ & $-0,21^{*}$ & $0,70^{* *}$ & $-0,18^{*}$ & $1,00^{* *}$ \\
\hline
\end{tabular}

Megjegyzés: * jelzi az 5 százalékos, ** az 1 százalékos szignifikanciaszinten szignifikáns korrelációkat. A felsố háromszög tartalmazza a korrelációkat, az alsó háromszög pedig a rangkorrelációkat. 
megfigyelhető. Tehát a profithatékonyság robusztusabb a becslési eljárásra, mint a költséghatékonyság.

A korrelációkból levont következtetésekkel összhangban lévô megállapításokra juthatunk, ha a különböző módszerek által legjobbnak és legrosszabbnak tartott bankok halmazát hasonlítjuk össze (4.3 as táblázat). A legfelsố és legalsó kvartilisbe sorolt azonos bankok aránya alapján is meglehetôsen eltérô eredményekre jut a két módszercsalád, és ebben az esetben is a DEA modellek eredményei állnak közelebb egymáshoz. Azt a korábbi eredményt is visszakaptuk, hogy a profithatékonyságra vonatkozó SFA modellek nagyobb hasonlóságot mutatnak a DEA-s eredményekkel, mint a költséghatékonyságra vonatkozók, függetlenül attól, hogy a DEA becslés profitra vagy költségre vonatkozott-e.

A becsült hatékonytalanságok időbeli stabilitását az autokorrelációk segítségével néztük meg (4.4 es táblázat). Egyik modellbecslés sem mondható erôsen autokorreláltnak, és közepes autokorreláció is csak az elsőrendú esetben figyelhetô meg. A parametrikus és nemparametrikus módszerek összehasonlításánál nem lehet általánosságban stabilabbat kihozni, a feltételektől és az autokorreláció rendjétôl függ, hogy melyik modell a stabilabb. Ellenben a profithatékonyságok egyértelmúen erősebben autokorreláltak, mint a költséghatékonyságok, kivéve a negyedrendú autokorrelációt. Hasonlóan, az értékvesztés nélkül becsült modellek általánosan stabilabbnak tûnnek, mint az értékvesztést is figyelembe vevô számítások, amelyek esetében ráadásul negatív autokorreláció is több esetben előfordul. Ennek vélhetôen az az oka, hogy az értékvesztések pontos mértékét számviteli megfontolások is nagy mértékben képesek befolyásolni, illetve a prudens bankok nagy várható veszteségek esetén hajlamosak nagyobb értékvesztés elszámolására, amelyet a tényleges veszteségek realizálása után részben visszaírnak.

Mivel gyenge idôbeli stabilitást találtunk, megnéztük a hatékonytalansági mutatók autokorrelációját intézményenként is, hogy lássuk, mekkora a heterogenitás a bankok között (4.5-ös táblázat). A hitelezési veszteséget is figyelembe vevô költséghatékonysági becsléseknél mind a DEA, mind az SFA modellel alacsony autokorrelációt kaptunk szinte minden intézmény esetén. A többi becslés ezzel szemben intézményi szinten nagy mértékú heterogenitást mutat, a legtöbb esetben az enyhén negatív korrelációtól a kifejezetten magas korrelációig terjednek az eredmények. Ez 
4. fejezet. Banki hatékonyság és piaci erố mérése a háztartási és a vállalati hitelpiacon

4.3. táblázat: A legjobb és legrosszabb bankok besorolása

\begin{tabular}{|c|c|c|c|c|c|c|c|c|c|}
\hline & & DEA & & & & SFA & & & \\
\hline & & $\begin{array}{l}\text { Profit } \\
\text { érték- } \\
\text { vesz- } \\
\text { téssel }\end{array}$ & $\begin{array}{l}\text { Költség } \\
\text { érték- } \\
\text { vesz- } \\
\text { téssel }\end{array}$ & Profit & Költség & $\begin{array}{l}\text { Profit } \\
\text { érték- } \\
\text { vesz- } \\
\text { téssel }\end{array}$ & $\begin{array}{l}\text { Költség } \\
\text { érték- } \\
\text { vesz- } \\
\text { téssel }\end{array}$ & Profit & Költség \\
\hline \multirow[t]{4}{*}{ DEA } & $\begin{array}{l}\text { Profit } \\
\text { érték- } \\
\text { vesz- } \\
\text { téssel }\end{array}$ & 1,00 & 0,52 & 0,65 & 0,48 & 0,33 & 0,21 & 0,23 & 0,19 \\
\hline & $\begin{array}{l}\text { Költség } \\
\text { érték- } \\
\text { vesz- } \\
\text { téssel }\end{array}$ & 0,40 & 1,00 & 0,33 & 0,67 & 0,27 & 0,29 & 0,27 & 0,17 \\
\hline & Profit & 0,69 & 0,35 & 1,00 & 0,35 & 0,33 & 0,19 & 0,27 & 0,19 \\
\hline & Költség & 0.44 & 0.44 & 0.54 & 1.00 & 0.21 & 0,21 & 0,23 & 0,17 \\
\hline \multirow[t]{4}{*}{ SFA } & $\begin{array}{l}\text { Profit } \\
\text { érték- } \\
\text { vesz- } \\
\text { téssel }\end{array}$ & 0,42 & 0,29 & 0,31 & 0,27 & 1,00 & 0,08 & 0,63 & 0,13 \\
\hline & $\begin{array}{l}\text { Költség } \\
\text { érték- } \\
\text { vesz- } \\
\text { téssel }\end{array}$ & 0,10 & 0,15 & 0,13 & 0,19 & 0,19 & 1,00 & 0,08 & 0,63 \\
\hline & Profit & 0,60 & 0,31 & 0,48 & 0,31 & 0,73 & 0,17 & 1,00 & 0,19 \\
\hline & Költség & 0,25 & 0,19 & 0,25 & 0,13 & 0,17 & 0,60 & 0,15 & 1,00 \\
\hline
\end{tabular}

Megjegyzés: a táblázatban szereplő értékek százalékok, a felsố háromszögben lévôk azt mutatják, hogy a legrosszabb kvartilisba tartozó bankok milyen arányban egyeztek meg. Alsó háromszögben ugyanez az érték szerepel a legjobb kvartilisre. 
4.4. táblázat: Autokorrelációk

\begin{tabular}{|l|l|l|l|l||l|l|l|l|}
\hline & DEA & & & & SFA & & & \\
\hline & $\begin{array}{l}\text { Profit } \\
\text { erték- } \\
\text { vesz- } \\
\text { téssel }\end{array}$ & $\begin{array}{l}\text { Költség } \\
\text { érték- } \\
\text { vesz- } \\
\text { téssel }\end{array}$ & Profit & Költség & $\begin{array}{l}\text { Profit } \\
\text { érték- } \\
\text { vesz- } \\
\text { téssel }\end{array}$ & $\begin{array}{l}\text { Költség } \\
\text { érték- } \\
\text { vesz- } \\
\text { téssel }\end{array}$ & Profit & Költség \\
\hline $\mathbf{1}$ & 0,32 & 0,12 & 0,49 & 0,37 & 0,49 & 0,18 & 0,47 & 0,30 \\
\hline $\mathbf{2}$ & 0,25 & $-0,03$ & 0,37 & 0,18 & 0,19 & $-0,15$ & 0,16 & 0,05 \\
\hline $\mathbf{3}$ & 0,20 & 0,01 & 0,18 & 0,09 & $-0,03$ & $-0,22$ & 0,11 & 0,09 \\
\hline $\mathbf{4}$ & 0,12 & 0,14 & 0,08 & 0,22 & $-0,14$ & $-0,09$ & 0,01 & $-0,01$ \\
\hline
\end{tabular}

arra utaló jel, hogy mintánkban gyakoriak az egyedi intézményeket érô, viszonylag nagy mértékû sokkok.

Végül a becsült hatékonytalansági mérôszámokat a pénzügyi mutatókból számolt jövedelmezôségi és hatékonysági mutatókkal vetjük össze (4.6-os táblázat). Négy pénzügyi adatsort használunk: ROAA - átlagos eszközre jutó bevétel, ROAE - átlagos tôkére jutó bevétel, TC/TA - eszközarányos összes költség, ER - hatékonysági ráta (a nem kamat jellegú kiadások és a bevételek hányadosa). Mivel az elsô kettő esetében a nagyobb érték jövedelmezôbb bankot, utóbbi kettônél pedig kevésbé hatékony bankot jelez, elsô kettôvel azt várjuk, hogy a becsült értékek negatívan, utóbbi kettôvel pedig pozitívan korreláljanak. Modelljeink e szempont szerint is nagyon vegyes eredményeket adnak: a ROAA és a ROAE esetében a profithatékonytalansági becslések hozzák szignifikánsan és megfelelő elôjellel a várt eredményeket, és az SFA-becslések jobban teljesítenek, mint a DEA-sek. Ez az eredmény nem meglepô, hiszen a jövedelmezôség a költségeket és a bevételeket egyaránt figyelembe veszi, ahogy a profithatékonyság-becslés is. Az eszközarányos összes költség mutató esetében viszont egyértelmúen a DEA-becslések teljesítenek jobban, függetlenül attól, hogy költség-, vagy profithatékonyságot mérnek, az SFAbecsléseknél még előjelben sem egyezik az eredmény. A hatékonysági ráta kapcsán teljesítenek legrosszabbul a modellek, csak a DEA-s, értékvesztés nélkül számolt 
4.5. táblázat: A hatékonytalansági mutatók elsôrendû autokorrelációja bankonként

\begin{tabular}{|c|c|c|c|c|c|c|c|c|}
\hline & DEA & & & & SFA & & & \\
\hline & $\begin{array}{l}\text { Profit } \\
\text { érték- } \\
\text { vesz- } \\
\text { téssel }\end{array}$ & $\begin{array}{l}\text { Költség } \\
\text { érték- } \\
\text { vesz- } \\
\text { téssel }\end{array}$ & Profit & Költség & $\begin{array}{l}\text { Profit } \\
\text { érték- } \\
\text { vesz- } \\
\text { téssel }\end{array}$ & $\begin{array}{l}\text { Költség } \\
\text { érték- } \\
\text { vesz- } \\
\text { téssel }\end{array}$ & Profit & Költség \\
\hline 1 & $0,91^{*}$ & 0,45 & $0,78^{*}$ & $0,61^{*}$ & $0,75^{*}$ & $0,18 \#$ & $0,81^{*}$ & $0,19 \#$ \\
\hline 2 & 0,21 & $-0,11 \#$ & $0,12 \#$ & 0,45 & 0,59 & $0,09 \#$ & 0,28 & $0,16 \#$ \\
\hline 3 & 0,47 & $-0,09 \#$ & $0,71^{*}$ & 0,45 & 0,59 & 0,29 & $0,72^{*}$ & $0,62^{*}$ \\
\hline 4 & $0,86^{*}$ & $-0,11 \#$ & 0,51 & $0,05 \#$ & 0,41 & 0,14 & 0,41 & $0,09 \#$ \\
\hline 5 & 0,40 & 0,32 & $0,66^{*}$ & $0,63^{*}$ & $0,76^{*}$ & $0,07 \#$ & $0,88 \#$ & $0,18 \#$ \\
\hline 6 & $0,00 \#$ & $-0,07 \#$ & 0,54 & $-0,07 \#$ & 0,2 & $-0,01 \#$ & $0,17 \#$ & 0,28 \\
\hline 7 & $-0,30 \#$ & $0,15 \#$ & $-0,2 \#$ & $0,10 \#$ & 0,40 & 0,38 & $0,13 \#$ & 0,29 \\
\hline 8 & $0,92^{*}$ & $0,85^{*}$ & $0,94^{*}$ & $0,79^{*}$ & 0,23 & $0,04 \#$ & $-0,04 \#$ & 0,37 \\
\hline 9 & $-0,42 \#$ & $0,15 \#$ & $-0,04 \#$ & 0,54 & $0,82^{*}$ & 0,40 & $0,72^{*}$ & $0,61^{*}$ \\
\hline 10 & 0,55 & $0,15 \#$ & $0,72^{*}$ & 0,20 & $0,16 \#$ & 0,37 & $0,77^{*}$ & 0,38 \\
\hline 11 & 0,31 & $-0,07 \#$ & $0,76^{*}$ & $0,14 \#$ & 0,47 & $0,08 \#$ & 0,47 & $0,13 \#$ \\
\hline 12 & $-0,12 \#$ & $-0,15 \#$ & 0,35 & 0,57 & 0,54 & $0,12 \#$ & 0,32 & 0,28 \\
\hline
\end{tabular}

Megjegyzés: A táblázatban *-gal jelöltük a 0,6-nél magasabb (erôs) korrelációkat, \#-tel a 0,2-nél kisebb (gyenge) korrelációkat. 
4.6. táblázat: A becsült hatékonytalanságok összehasonlítása a pénzügyi jövedelmezőségi és hatékonysági mutatókkal

\begin{tabular}{|l|l|l|l|l||l|l|l|l|}
\hline & DEA & & & & SFA & & & \\
\hline & $\begin{array}{l}\text { Profit } \\
\text { érték- } \\
\text { vesz- } \\
\text { téssel }\end{array}$ & $\begin{array}{l}\text { Költség } \\
\text { érték- } \\
\text { vesz- } \\
\text { téssel }\end{array}$ & Profit & Költség & $\begin{array}{l}\text { Profit } \\
\text { érték- } \\
\text { vesz- } \\
\text { téssel }\end{array}$ & $\begin{array}{l}\text { Költség } \\
\text { érték- } \\
\text { vesz- } \\
\text { téssel }\end{array}$ & Profit & Költség \\
\hline ROAA & $-0,14$ & 0,14 & $-0,20^{*}$ & $0,23^{* *}$ & $-0,43^{* *}$ & $-0,09$ & $-0,35^{* *}$ & 0,11 \\
\hline ROAE & $-0,18^{*}$ & 0,07 & $-0,24^{* *}$ & $0,18^{*}$ & $-0,45^{* *}$ & $-0,04$ & $-0,37^{* *}$ & 0,12 \\
\hline TC/TA & $0,18^{*}$ & $0,39^{* *}$ & $0,35^{* *}$ & $0,33^{* *}$ & $-0,17^{*}$ & $-0,04$ & $-0,05$ & $-0,07$ \\
\hline ER & $-0,18^{*}$ & 0,07 & $-0,24^{* *}$ & $0,18^{*}$ & $-0,45^{* *}$ & $-0,04$ & $-0,37^{* *}$ & 0,12 \\
\hline
\end{tabular}

Megjegyzés: * jelzi az 5 százalékos, ** az 1 százalékos szignifikanciaszinten szignifikáns korrelációkat.

költséghatékonyság esetén tapasztalható pozitív korreláció 5 százalékos szignifikanciaszinten.

\subsubsection{A válság hatása a hatékonyságra}

Hatékonysági becsléseink eredményei azt mutatják, hogy a magyar bankok költséghatékonyságát tekintve relatíve homogén a szektor, a gyengébben teljesítô bankok is csak alig maradnak el a legjobb bank hatékonyságától. Az SFA modell eredményei ezt az állítást a teljes vizsgált perióduson igazolják, míg a DEA modell eredményei a minta utolsó néhány évére támasztják alá.

2005 óta a DEA- és az SFA-becslések összességében a magyar bankok költséghatékony határhoz való közeledését mutatják, melynek jelentôs része a válság kitörését követô költségalkalmazkodás során következett be 4.2 es ábra). Ezt a relatíve gyors alkalmazkodást azonban nem követte további, nagy mértékú javulás, amiben jelentôs szerepe volt a banki hitelállományok leépülésének (Magyarországon 2009 és 2015 között gyakorlatilag folyamatosan csökkent mind a háztartási, 
mind a vállalati hitelállomány), ami nem biztosított támogató környezetet a költséghatékonyság növeléséhez.

4.2. ábra: A hazai bankok költséghatékonyságának becslése SFA és DEA költségfüggvény alapján

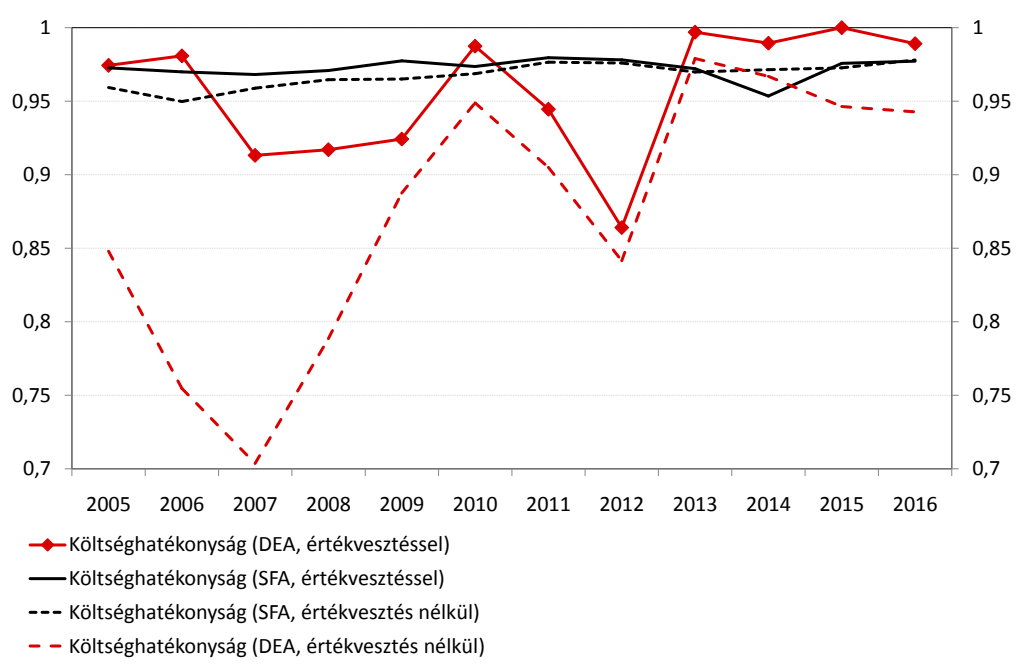

Megjegyzés: a fenti értékek az egyes bankok mérlegfőösszeggel súlyozott költséghatékonyságát mutatják, vagyis azt, hogy a bankok múködése átlagosan mennyire van közel a frontier bank múködésének hatékonyságához. A nagyobb értékek nagyobb hatékonyságra utalnak.

A hatékonysági becslések eredményei nem mentesek a kilengésektôl. A DEA becslések 2012-ben mutatnak jelentős csökkenést a hatékonyságban. E mögött egy állami intézkedés, a devizaalapú jelzáloghitelek kedvezményes árfolyamon történô végtörlesztése állhat, amely miatt rendkívül gyorsan, gyakorlatilag két negyedév alatt egy jelentôs volumenú, jól jövedelmezô portfólió került ki a bankok mérlegéból. Az intézkedés gyors lefolyása miatt a bankok csak némi késéssel tudtak alkalmazkodni a költségekben, ami átmenetileg a hatékonyság csökkenéséhez vezetett. Az értékvesztést is tartalmazó hatékonysági becslések 2014-ben is enyhe negatív kilengést mutatnak, amelynek hátterében két nagybank kimagasló értékvesztéselszámolása áll. A DEA-becslések láthatóan nagyobb mértékben eltérnek egymástól, mint az SFA-becslések, ennek oka vélhetôen, hogy míg az SFA-becsléseknél a 
sokkok egy részét véletlen hatásként identifikálja a modell, a DEA-k esetében ezek egy az egyben hatékonytalanságként jelennek meg.

A profithatékonyságot tekintve a költséghatékonysági becsléshez képest egyrészt sokkal nagyobb a szórás az intézmények között, másrészt sokkal kevésbé látszódik egyértelmú trend a vizsgált 11 éves periódus alatt. A válság előtti idôszak fokozatos romlással járt (4.3-as ábra), ami ezekben az években a bankrendszer eszköz- és tôkearányos jövedelmezőségének fokozatos csökkenésében is tükröződött. A hatékonyság csökkenése a piacok telítôdésére és a marzsok szúkülésére vezethetô vissza, aminek következtében adott mennyiségú input a korábbinál jóval kevesebb profitot eredményezett.

4.3. ábra: A hazai bankok profithatékonyságának becslése SFA és DEA költségfüggvény alapján

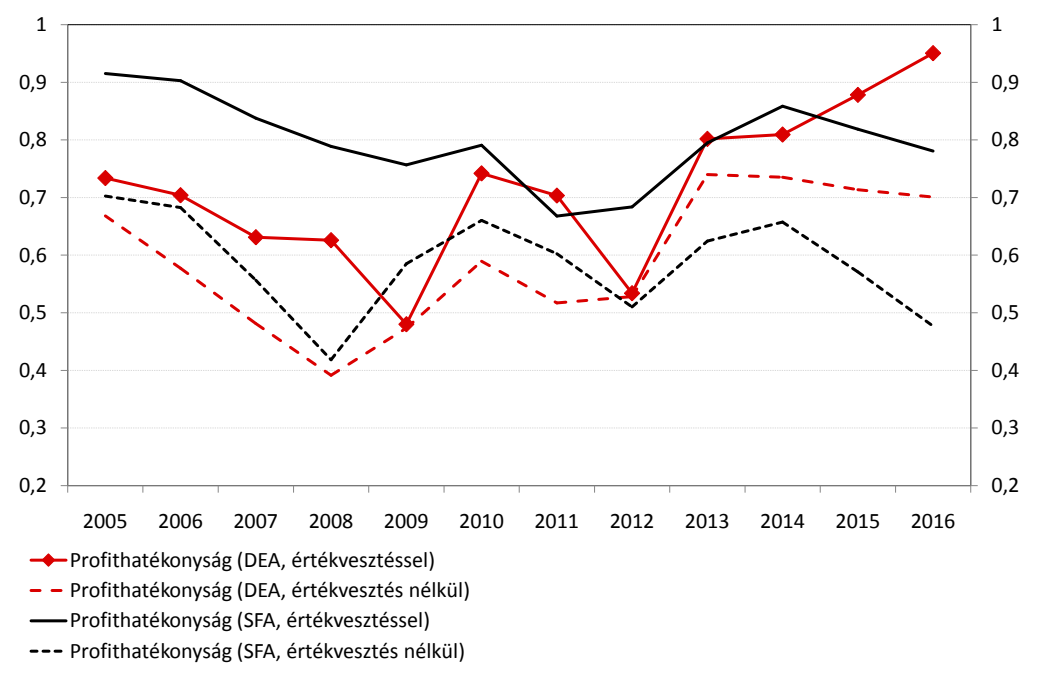

Megjegyzés: a fenti értékek az egyes bankok mérlegfőösszeggel súlyozott profithatékonyságát mutatják, vagyis azt, hogy a bankok múködése átlagosan mennyire van közel a frontier bank múködésének profithatékonyságához. A nagyobb értékek nagyobb hatékonyságra utalnak.

A profithatékonyság a válság kitörését követően érte el mélypontját: ebben az időszakban a nemteljesítô ügyletek arányának emelkedése és a kamatozó hitelállomány arányának lassú mérséklődése a kamatjövedelmek csökkenéséhez vezetett 
több intézmény esetében is, miközben a hitelezési veszteségek és a forrásköltségek is növekedésnek indultak. A kedvezményes árfolyamon történô végtörlesztés 2012-es évet érintő hatása a profithatékonysági becslések többségében is azonosítható. A minta utolsó négy évének átlaga becsléseink többsége alapján a válságperiódus átlagához képest összességében jobb profithatékonyságot mutat. Az utolsó négyéves periódust önmagában vizsgálva azonban enyhén eltérô képet kapunk a különbözô modellek alapján: a hitelezési veszteségeket is figyelembe vevó profithatékonyságban inkább javulás látszódik az értékvesztési igény csökkenésével párhuzamosan (a DEA modell egyértelmú hatékonyság növekedést mutat, míg az SFA inkább stagnálást), míg a csak forrás- és operatív költségeket tartalmazó profithatékonysági becslések eredményei inkább stagnálást, illetve enyhe romlást jeleznek.

\subsubsection{A háztartási és a vállalati Lerner-indexek}

Ahogy korábban már említettük, a háztartási és vállalati hitelpiac számos szempontból jelentős különbségeket mutat. Hipotézisünk szerint például a verseny intenzitása szempontjából is, ezen feltételezésünket Lerner-indexszel vizsgáltuk meg. A Lerner-index azt mutatja meg, hogy a vállalat által alkalmazott ár mekkora része a „tiszta” profit, ami nem a termék előállítási költségének fedezéséhez szükséges. Kiszámításának módja: Lerner $=\frac{p-M C}{p}$, ahol $p$ a termék árát, $M C$ a termék határköltségét jelöli. Tehát minél nagyobb az index értéke, annál nagyobb a szereplők piaci ereje és annál gyengébb a közöttük lévô verseny nagysága (Lerner (1934) ${ }^{12}$. Az SFA költségfüggvény felhasználásával lehetôségünk nyílt határköltségeket számítani mind a háztartási, mind a vállalati hitelpiacra vonatkozóan. A Lerner-indexet szegmensenként három verzióban készítettük el, melyek a hitelezési kockázatok figyelembevételében és abban különböztek, hogy az újonnan kibocsátott hitelekre, vagy a meglévő állományokra számítottuk-e:

\footnotetext{
${ }^{12}$ Felmerülhet, hogy a bankrendszeri piaci erô vizsgálatára nem alkalmas az index, mivel az a minden vevôt azonos áron kiszolgáló vállalat piaci erejének leírására szolgál, miközben a bankok árképzése egyedileg (ügyfelenként) történik. Utóbbi állítás azonban csak a banki portfólió egy részére igaz (elsôsorban a nagyvállalati szegmensben), míg a kisebb ügyfelek hiteleinek árképzése portfólió szinten, néhány változó alapján differenciálva történik. A Lerner-index alkalmazása a nemzetközi szakirodalomban is megszokott a banki piaci erô leírására.
} 
- Lerner-index a kapott kamatbevétel alapján az állományra. Ez esetben az árat (a Lerner-index $p$ értékét) az adott szegmensból kapott kamatbevétel és az adott szegmens felé fennálló hitelállomány hányadosaként kaptuk. A határköltség becslése abból a modellből származik, amelyben nem szerepeltek az értékvesztések, csak az operatív költségek és a forrásköltségek.

- Lerner-index az állományi kamatlábak alapján az állományra. Az index árjellegú változója az idôszak végi állománnyal súlyozott kamatláb. A határköltség ebben az esetben a hitelezési veszteségek nagyságát is tartalmazza.

- Lerner-index az új szerződések hitelköltsége / kamatlába alapján az új hitelekre. Az index árjellegú változója az adott évben kötött szerzôdések hitelösszeggel súlyozott átlagos kamatlába a vállalatok esetében, illetve teljes hitelköltség-mutatója a háztartási szegmensben. A határköltség ebben az esetben is tartalmazza a hitelezési veszteségeket: a teljes minta során megfigyelt hitelezési veszteségeket átlagoltuk minden egyes bankra, így egy cikluson átívelő hitelezési veszteséggel számoltunk az új hitelek esetén. Ahogy korábban is hangsúlyoztuk, az új hitelek árát az összetételhatás akár jelentôs mértékben is befolyásolhatja, főleg a vállalati szegmensben, ahol a rövid lejáratú, nagyösszegú, alacsony kamatlábbal rendelkezô hitelek egy-egy bank esetében akár dominálhatják is az átlagos kamatokat. Ennek tükrében érdemes a három indexet együtt értelmezni, és az új hitelek alapján számolt indexet önmagában csak kellő óvatossággal vizsgálni.13

Az így kapott indexek alapján elmondható, hogy a vizsgált periódus alatt a vállalati hitelpiacon többnyire rendkívül éles, míg a háztartási hitelpiacon kevésbé intenzív verseny volt tapasztalható. Ez az eredmény jól illeszkedik a magyar bankversenyrôl szóló szakirodalom korábbi megállapításaihoz is. Továbbá, a hitelezési

\footnotetext{
${ }^{13} \mathrm{Az}$ összetétel hatás elméletileg kiszürhetô lenne, ha a becsült költségfüggvényekben a háztartási és a vállalati hitelállomány outputokat tovább bontanánk és termékszintû outputokkal végeznénk el a becslést. Így lehetôség lenne arra, hogy a termékszintű határköltségek és kamatlábak segítségével termékszintú Lerner-indexeket számoljunk. Ehhez azonban a költségfüggvényben szereplô változók oly mértékû növelése lenne szükséges, amely a mintánk elemszáma mellett semmiképp sem lehetséges.
} 
4.4. ábra: Becsült Lerner-indexek a vállalati hitelpiacon

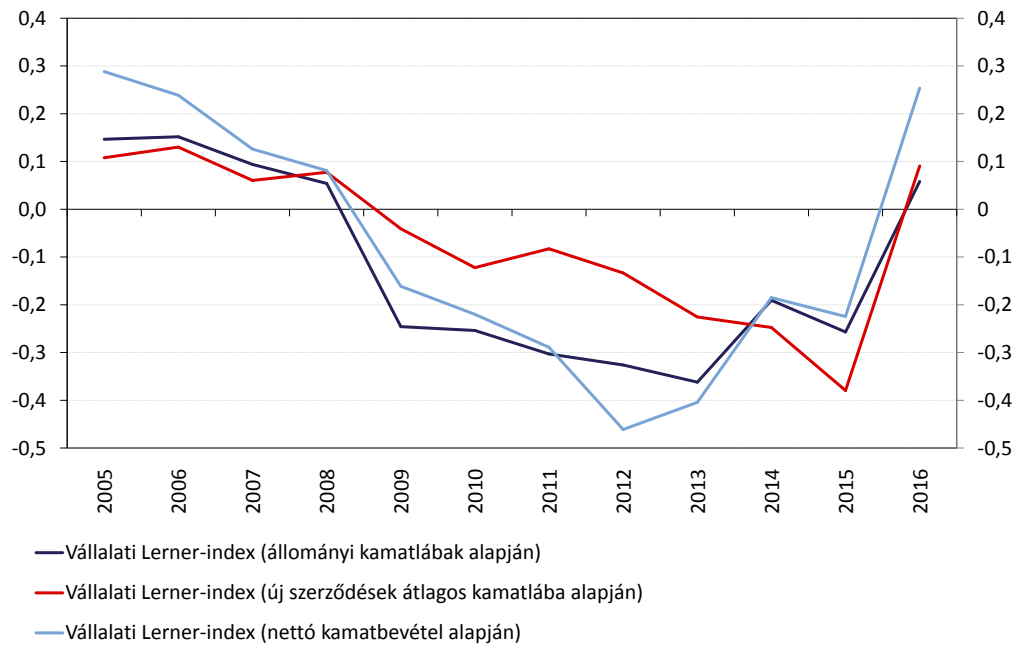

kockázatok eltérô módon történô figyelembe vétele nem módosít a következtetéseken, szintben és dinamikában is nagyon hasonló képet mutatnak.

A vállalati hitelpiacra számított Lerner-indexek (4.4 es ábra) a válság kitöréséig pozitív tartományban, enyhén a nulla szint felett helyezkedtek el, szinte folyamatosan mérséklődő tendenciát mutatva, ami éles versenyre utal a szegmensben. A válság kitörését követően meredek csökkenés látszódik, leginkább a kamatbevétel és az állományi kamatláb alapján számolt indexek esetében. Utóbbiaknál a csökkenés azt tükrözi, hogy a bankok e hitelek esetében nem árazták be jól a hitelkockázatot, és a hitelezési veszteségek felmerülésekor a befolyt kamatok nem voltak elegendôek ahhoz, hogy a költségeket fedezni tudják.

Az újonnan kötött szerződések esetében a válság évei alatt összességében szintén csökkenő tendencia volt megfigyelhető az index értékeiben. Az index csökkenésének üteme azonban valamelyest lassabb volt, mint az állományi indexek esetében. Ez abból fakadt, hogy az új hiteleken a bankok valamelyest képesek voltak emelni a felárat, áthárítva a felmerülő hitelezési veszteségeket, míg a már fennálló állományon erre nem voltak képesek. Ennek ellenére az új szerzôdések indexe esetében is csökkenő tendencia figyelhetô meg, ráadásul az index értéke stabilan negatív tar- 
tományban mozog, ami az új ügyfelekért folytatott éles versenyt tükrözi. A válság kitörését követően ugyanis a bankok mindegyike jelentôsen szigorított a hitelsztenderdjein, és a még így is hitelképesnek minősített kisszámú vállalatért nagyon intenzív verseny folyt. A vállalatok olyan erôs alkupozícióval rendelkeztek, hogy a bankok által ajánlott kamatlábak sok esetben a költségeket sem fedezték. ${ }^{14}$

A csökkenô tendencia az utóbbi években megfordult és mindhárom index növekedni kezdett: az állományi alapon számolt indexek 2012-ben és 2013-ban, míg az új szerzôdések kamatlába alapján számolt index 2015-ben érte el minimumát.15 Az index növekedésében jelentôs szerepet játszott, hogy a gazdasági növekedés és ingatlanpiac élénkülésének hatására csökkentek a hitelezési kockázatok, másrészt a kamatcsökkentési ciklus, valamint a jegybank hitelösztönző programjai (Növekedési Hitelprogram (NHP) és a Piaci Hitelprogram (PHP) $)^{16}$ eredményeként jelentôsen mérséklődtek a bankok forrásköltségei is. Az index emelkedéséhez összetételhatás is hozzájárult: az utóbbi években - az NHP-tól nem függetlenül - átrendeződött a vállalati hitelezés szerkezete a kisebb méretû és kisebb piaci erôt képviselő vállalatok irányába, miközben az erôs alkupozícióban lévô nagyvállalatok növekvô aránya már közvetlenül külföldről vont be finanszírozási forrást. Tehát ebben a szegmensben emelkedett azon vállalatok aránya, akikkel szemben a bank érvényesíteni képes piaci erejét. Mindezek következtében 2016-ban mindhárom Lerner-index újra pozitív értéket vett fel, ami arra utaló jel, hogy a bankrendszer a vállalati hitelpiacon is kezdi visszanyerni nyereségtermelö-képességét.

A háztartási hitelpiacon 2004-től kezdődően a devizahitelezés felfutásával egyre intenzívebbé váló verseny volt megfigyelhetô (4.5)ös ábra). Ezt az időszakot gyakran illeti a szakirodalom a kockázatalapú verseny kifejezéssel Banai et al. (2010)), ami arra utal, hogy a bankok közötti növekvố verseny nem az árak csökkenésében, hanem az egyre nagyobb kockázatok vállalásában érvényesült. A válság kitörése

\footnotetext{
${ }^{14}$ Ugyanakkor a hitelfolyósításon kívül a bank számos egyéb úton is bevételhez juthatott e vállalatoktól: pénzforgalmi szolgáltatásokat nyújthatott, illetve befektetési és derivatív ügyleteket köthetett a vállalat számára jutalékért. Így összességében a banknak megérhette a határköltség alatt áraznia az egyes hiteleket annak érdekében, hogy az ügyfél ne pártoljon át másik bankhoz.

${ }^{15}$ Itt hangsúlyoznunk kell, hogy az újonnan szerződött hitelek átlagos kamatlábát a vállalati hitelek esetében az összetételhatás akár jelentôs mértékben is torzíthatja.

${ }^{16} \mathrm{~A}$ jegybank hitelösztönzô eszközeirôl részletesebben ld. Bodnár et al. (2017) tanulmányát.
} 
4.5. ábra: Becsült Lerner-indexek a háztartási hitelpiacon

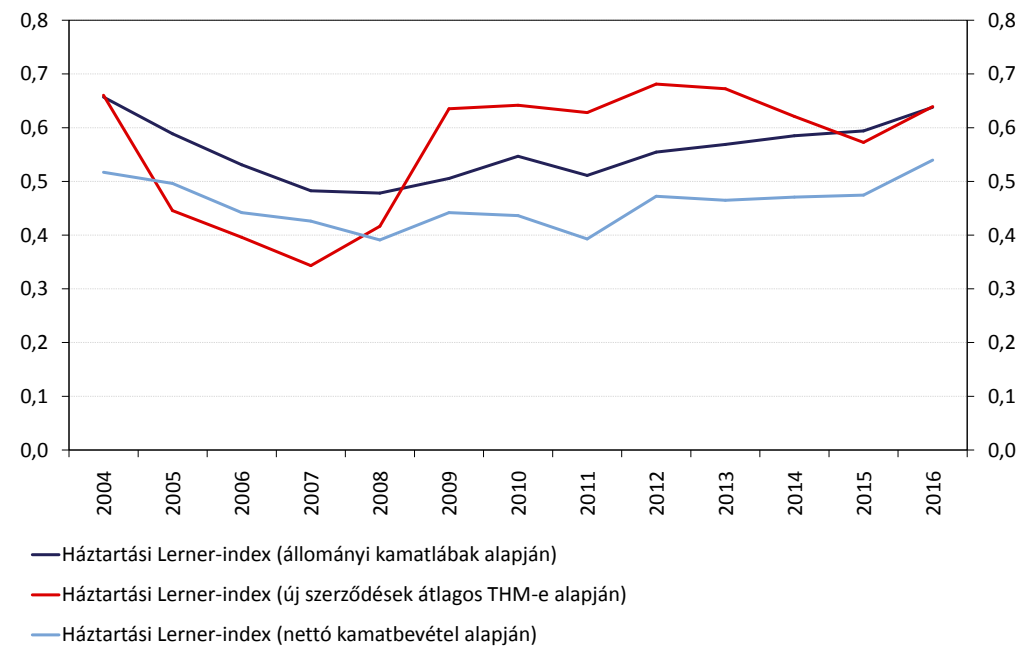

után azonban az új hiteleknél szinte azonnal, az állománynál pedig fokozatosan visszaemelkedett az index a 2004-es szintre. A vállalati szegmenshez képest szembetûnô, hogy a háztartásokkal szemben a bankoknak egyértelmúen megmaradt a piaci fölénye, ami a vállalati hitelektôl eltérôen a már fennálló állomány hitelkamatainak egyoldalú növelésében is testet öltött. ${ }^{17}$

Az új szerzôdéskötések indexében a válság kitörését követően 2011-ig nem volt jelentôs változás, majd 2012-ben a végtörlesztés idején magas kamatláb mellett folyósított kiváltó hitelek emelték meg az index értékét.18 2013-tól kezdve egészen 2015-ig a növekvő hitelkínálat és az élénkülő hitelpiac mentén csökkent az index értéke. 2016-ban a bankok a javuló hitelezési veszteségek és gazdasági kilátások ellenére ismét emeltek feláraikon, ami az index újbóli emelkedéséhez vezetett.

\footnotetext{
${ }^{17}$ Ahogy korábban is említettük, ebben nagy szerepet játszott, hogy míg a vállalati hitelek árazása jellemzôen valamilyen referenciakamathoz volt kötve, addig a lakossági hitelszerződések kamatlába a bank egyoldalú döntésétôl függôen módosítható volt.

${ }^{18}$ A késóbbi vizsgálatok szerint a bankok ebben az idôszakban összehangolták stratégiájukat és kollektív módon csökkentették hitelkínálatukat, ezt tükrözték a hirtelen élesen emelkedô kamatlábak. A Gazdasági Versenyhivatal a vizsgálatot követően összesen 9,5 milliárd forintos bírsággal büntette az összejátszó intézményeket.
} 
Az állományi folyamatokat bemutató indexek esetében ezzel szemben fokozatos és szinte folyamatos emelkedés volt megfigyelhetô a válság kitörésétől egészen napjainkig. Ebben a tendenciózus emelkedésben még a kamatlábak törvényi erôvel történő csökkenése (2015-ös elszámolás és forintosítás) sem okozott törést, amiben az enyhülő forrásköltségeknek és a csökkenő hitelezési veszteségeknek volt jelentôs szerepe.19 Összességében kijelenthetô, hogy a bankok 2016-ban is magas piaci erôvel rendelkeztek a háztartási hitelpiacon.

A Lerner-index eredményeit érdemes párhuzamba állítani az egyszerúbb, a kamatláb és a pénzpiaci kamatlábak különbözetére épülő pénzügyi mutatók alakulásával is. ${ }^{20}$ A 4.6 os ábra az új kibocsátású hitelek esetén mutatja mindkét szegmensre a felárak nagyságát a teljes bankrendszer szintjén (tehát nem csak a korábban bemutatott mintára). Fontos hangsúlyozni, hogy ez a mutató több okból is eltér a Lerner-index értékeitől: egyrészt a felmerülő költségek közül csak a forrásköltségek nagyságát veszi figyelembe, másrészt ezt a forrásköltséget egyenlôvé teszi a rövid lejáratú pénzpiaci kamatokkal, miközben a bankok által ténylegesen bevont források ára jellemzôen eltér ettôl. Így például nem vesszük figyelembe a devizaforrások válság kitörését követô drágulását (az országkockázat növekedése miatt), valamint az utóbbi évek betéti forrásainak olcsóbbá válását sem (a folyószámlabetétek növekvố aránya miatt). A Lerner-index ezzel szemben a bankok valós forrásköltségeit és az ebből számolt határköltséget is képes figyelembe venni, miközben a múködési költségek és a hitelezési veszteségek hatását is magába foglalja.

A háztartási felárak jóval magasabbak a vállalati szegmensben alkalmazottnál, ami részben megerôsíti a Lerner-index eredményeit, részben pedig a figyelembe nem vett egyéb költségelemek hatását tükrözi. A háztartási szegmens átlagos felára dinamikájában hasonlít a Lerner-index alakulásához, ugyanúgy elkülöníthetőek a válság elôtti élénkülő verseny jelei, a válság hatására megemelt hitelköltségek, valamint az utóbbi években tapasztalható élénkülés is.

\footnotetext{
${ }^{19}$ A bankok jelentôs része 2015-ben és 2016-ban is értékvesztést írt vissza, vagyis a hitelezési „,veszteségeik" nettó értelemben a profit növekedéséhez járultak hozzá (MNB (2016), MNB (2017)).

${ }^{20} \mathrm{Az}$ egyszerú felárak alakulását az MNB rendszeres kiadványai is nyomon követik: mind a negyedévente megjelenő Hitelezési folyamatok kiadvány, mind a félévente megjelenő Pénzügyi Stabilitási Jelentés tartalmaz a felárakra vonatkozó elemzést.
} 
4.6. ábra: Az újonnan szerződött hitelek pénzpiaci kamatok feletti átlagos felára

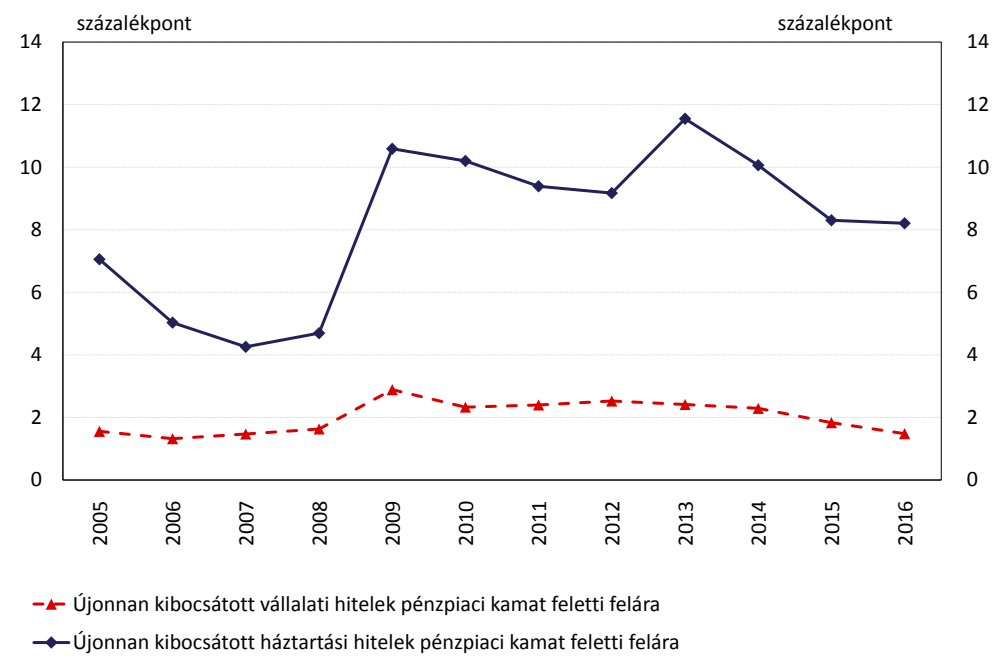

Megjegyzés: háromhónapos BUBOR, EURIBOR és CHF LIBOR feletti felárak szerzôdéses összeggel súlyozott 12-havi átlaga. A vállalati idôsorban a kibocsátott NHP hiteleket a jegybanki refinanszírozás 0 százalékos forrásköltségével vettük figyelembe. Forrás: MNB.

A vállalati hitelek esetében pusztán a pénzpiaci kamatok feletti felárak alapján kevésbé rajzolódnak ki a korábban tárgyalt tendenciák. E mögött részben az eltérô forrásköltségek játszanak szerepet: a valós forrásköltségekkel számolva a válság kitörését követően a felárak az ábrán lévőnél jóval alacsonyabban, míg az utóbbi években magasabban lennének, így jobban tükröznék a Lerner-index korábban látott alakulását. A forrásköltségek különbözősége mellett az is szerepet játszik, hogy az egyszerú felárak számításakor pont az egyik legfontosabb dimenzió, azaz a hitelezési veszteségek hatását nem vesszük figyelembe. Korábban épp azzal érveltünk, hogy a bankok által alkalmazott kamatlábak nem voltak elegendók arra, hogy a fellépô hitelezési veszteségeket fedezzék. Ez a szempont azonban elveszik, ha csak a pénzpiaci kamatok feletti felárakat vizsgáljuk. Végül, ahogy korábban is hangsúlyoztuk, a vállalati új kibocsátás esetén az összetételhatás is nagyobb szerepet játszik (a rövid lejáratú money-market jellegú ügyletek változó, gyakran domináns súlya miatt), ami jelentősen megnehezíti a megfelelő következtetések levonását. 


\subsection{A fejezet összegzése}

Tanulmányunkban a magyar bankrendszer költség-, és profithatékonyságát vizsgáltuk parametrikus és nemparametrikus modellek segítségével a hitelezési kockázatok figyelembe vételével, illetve a nélkül. A modellek eredményeit összevetettük egymással, és azt is megvizsgáltuk, mely becslések stabilabbak idóben, és melyek mozognak együtt a pénzügyi mutatókból számolt jövedelmezőségi és hatékonysági mutatókkal. Majd több módon is Lerner-indexet számoltunk külön a háztartási és a vállalati hitelpiacra.

Eredményeink szerint a magyar bankrendszer költséghatékonyság szempontjából homogén, profithatékonyság terén viszont heterogénnek tekinthetô, nagy különbségek vannak az intézmények között. A két modellezési technika közül a DEA modellek hajlamosabbak a szélsôséges értékek kimutatására. A különbözô modellek eltérôen ítélik meg az egyes bankok teljesítményét: a DEA modellek eredményei közepesen korreláltak, SFA modellek esetén külön-külön a profit- és a költséghatékonyságra kaptunk erôsen együttmozgó eredményeket, míg a profithatékonyságra kapott becslések modellcsaládtól függetlenül is szignifikánsan korreláltak egymással. Idôbeli stabilitás szempontjából a parametrikus és nemparametrikus módszerek közül nem lehet egyértelmúen jobb teljesítményút választani, a profithatékonyság viszont ezúttal is jobban teljesített a költséghatékonysági becsléseknél. Az értékvesztés figyelembevétele ugyanakkor gyengítette az idóbeli stabilitást. A teljesítményt mérô pénzügyi mutatókkal történô összehasonlítás során a jövedelmezôségi mutatókkal (ROAA, ROAE) a profithatékonysági becslések mozogtak együtt, az eszközarányos összköltséggel pedig a DEA modellek eredményei, a hatékonysági rátával egyik modell sem mutatott erôs kapcsolatot. Összességében tehát, amennyiben szabályozói döntés támogatására készül banki hatékonyág becslés, érdemes több modell eredményét összevetni az eltérô információtartalom miatt.

A válság a rendszerszintû költséghatékonyságra pozitív hatást gyakorolt, a negatív sokkra a bankok tevékenységük racionalizálásával válaszoltak, valamint a kevésbé hatékony intézmények csődje vagy felvásárlása is javíthatta a rendszerszintú eredményeket. Profithatékonyság szempontjából a válság utáni elsô éveket a megemelkedett hitelezési veszteségek és a kieső bevételek miatt romlás jellemezte, azon- 
ban a gazdasági növekedés javulása, a hitelezési veszteségek csökkenése és a banki múködés racionalizálása az utóbbi években már profithatékonyság szempontjából is javulást hoztak.

Az SFA-típusú költségfüggvények felhasználásával Lerner-indexet becsültünk külön a háztartási és a vállalati hitelpiacra. A két szegmens meglehetôsen eltérô képet mutat piaci erô szempontjából: a háztartási hitelpiacon a bankokat végig magas Lerner-index jellemezte, míg a vállalati hitelpiacon intenzív, sôt túlzott versenyt lehetett megfigyelni. Kétféle Lerner-indexet becsültünk, amely a hitelezési kockázatok figyelembevételében különbözött, erre az eltérésre eredményeink robusztusnak bizonyultak. Az új hitelekre számolt Lerner-indexek mind a két piacon gyorsabb reagálásúnak mutatkoztak az állományi indexeknél. Összességében a piaci erő ilyen mértékú különbsége azt jelzi, hogy szabályozói szempontból érdemes a két piacot külön modellezni. 
A magyar bankrendszer makroprudenciális szempontból 


\section{5. fejezet}

\section{Összegzés}

A doktori értekezés hipotézisei és a fentebb bemutatott modellek a magyar bankrendszer múködéséhez kapcsolódtak. Ökonometriai eszközökkel olyan kérdésekre kerestük a választ, amelyek (elsősorban) makroprudenciális szabályozói szempontból érdekesek. Az első fejezetben röviden áttekintettük a magyar bankrendszer elmúlt 15 évének legfontosabb történéseit a vállalati és a háztartási hitelpiac tekintetében, beleértve a válság utáni szabályozói intézkedéseket is. Majd három fejezetben három ökonometriai modellt ismertettünk, melyek hitelkínálati sokkok hatását, a jövedelemarányos törlesztôrészlet és a nemteljesítési valószínúség kapcsolatát, valamint a bankrendszer hatékonyságát és a hitelpiacokon tapasztalható verseny intenzitását vizsgálták. Modelljeinket statisztikai tesztek, szakértői megfigyelések, és más tanulmányok eredményeivel való összevetés segítségével validáltuk (sôt, az értekezés különböző fejezeteinek következtetései is erôsítik egymást). Eredményeink jól használhatók a makroprudenciális politikai döntések támogatására, mivel segítséget nyújtanak - többek között - a túlzott htelezéssel vagy hitelszúkével jellemezhetô időszakok beazonosításában, az optimális jövedelemarányos törlesztôrészlet-szabály meghatározásában, illetve a hitelpiacok hatékony múködésének ellenőrzésében.

A második fejezetben egy időben változó paraméterú dinamikus faktormodellt használtunk, a következôben egy logit-becslést, a negyedikben pedig SFA- és DEAtípusú modellekbôl vontunk le következtetéseket. Adatok tekintetében mind a há- 
rom vizsgált adatbázis rendelkezett keresztmetszeti dimenzióval, a faktor- és a hatékonysági modellek esetében azonban paneladatbázist használtunk. Utóbbiaknál 2001-tôl kezdődően áltak rendelkezésre az adatok negyedéves, illetve éves frekvencián. Mindhárom esetben figyelembe vettük, hogy a változó múködési környezet miatt a megfigyelt mintánkon időben változhatott a sokkok valószínúsége, illetve a parciális hatások mértéke: a dinamikus faktormodellünk paraméterei idóben változó módon lettek megbecsülve, a PD-modellnél idôszak-dummykat használtunk, míg a hatékonysági modelleknél a becsült hatékonytalansági hibatag változhatott évrôl évre. A PD-modellt csak a háztartási hitelpiacra alkalmaztuk, a másik kettôt a háztartási mellett a vállalatira is, azonban figyelembe vettük a két szegmens eltérô tulajdonságait.

Értekezésünk során számos hipotézist felállítottunk és megvizsgáltunk. Ezeket tekintjük most át, illetve összevetjük más szerzôk eredményeivel és saját várakozásainkkal következtetéseinket. Elôször a faktormodellre, majd a logit-becslésre, végül a banki hatékonyságra és Lerner-indexre vonatkozó hipotéziseket nézzük át.

- A hitelkínálati sokkok várható értéke megnoottt a válság után: a magyar bankrendszerre nem készült olyan becslés, amely időben változó módon vizsgálta volna a hitelkínálati sokkok hatását. Mivel azonban a válság után számos mikro- és makroprudenciáls szabályozói intézkedést vezettek be - és várhatóan fognak még bevezetni - előzetesen arra számítottunk, hogy a hitelkínálati sokkok várható mértéke nôtt a válság után. A FAVAR VARegyenleteihez tartozó hibatagok szórásának növekedése ezen hipotézisünket alá is támasztotta.

\section{- A hitelkínálatot meghatározó folyamatokat érdemes külön válasz-} tani két faktorba: képességre és hajlandóságra. Faktormodellünk és a VAR-ból kapott impulzusválaszok is alátámasztották, hogy két fontos hitelkínálati faktort lehet számszerúsíteni adatainkból. Ez újdonság a szakirodalomban, általában egy hitelezési vagy pénzpiaci faktort számserúsítenek. Ugyanakkor eredményünk hasonló Tamási és Világi (2011) cikkhez, ahol két hitelkínálati sokk hatását vizsgálják. 
- Hitelezési aktivitás szempontjából a magyar bankok hitelkínálatát az anyabankok tôke- és likviditási helyzete nagyobb mértékben határozta meg, mint a hazai leánybankoké: Ennek oka, hogy a magyar bankrendszer nagyobb része a vizsgált időszakban külföldi anyabankok tulajdonában volt. Korábbi kutatások (Bethlendi (2007) $)$ szerint a külföldi anyabankok úgynevezett aktív tókemendzsmentet folytattak, azaz annyi tôkét és likvid eszközt tartottak a leánybankoknál, hogy azok állománya éppen megfeleljen a szabályozói elôírásoknak, és mindig annyival emelték ezek szintjét, amennyire éppen szükség volt. Ezért a leánybankok tőke és likviditási mutatószámai nem mutattak reális képet a szabályozói előírások hitelezést korlátozó hatásáról. Eredményeink alátámasztották ezt a hipotézist, az elsô hitelezési faktor loadingjai között az anyabankok tőkeáttétele meghatározóbb változónak bizonyult, mint a leánybankoké.

- Hitelezési képességi sokk hatására nem nôtt a hitelállomány: Mivel hitelkínálati sokkot vizsgáltunk, azt vártuk, pozitív hatást gyakorol a sokk a hitelállományokra. Ez a hipotézisünk nem bizonyult igaznak, ennek magyarázata, hogy az előzô pontban említett aktív tôkemendzsment hatására a leánybankok szolvencia és likviditási mutatói hiába voltak közel a szabályozói előírásokhoz, tényleges korlátot nem jelentettek.

- Hitelezési képességi sokk hatására csökkent az országkockázat és az alapkamat: A válság kitörése után nagy figyelem irányult az EU magasabb államadóssággal rendelkező országaira (elsôsorban: Görögország, Spanyolország, Olaszország, Írország, Portugália), ahol egy esetleges bankválság további terheket rótt volna a költségvetésre, ezzel is növelve az államcsôd kockázatát. Mivel a válság után Magyarországot is magas államadósság és gyenge adósbesorolás jellemezte, a hazai bankok csôdközeli helyzete is súlyos problémát jelentett volna szuverén kockázat szempontjából. Ezért a hitelezési képesség javulása esetén az országkockázat csökkenését vártuk. Az állampapírok felárának impulzusválaszai alátámasztották hipotézisünket. Továbbá, a csökkenô országkockázat az alapkamatra is csökkentőleg hatott. Ez az eredmény magyar adatokon újdonság. 
- A hitelezési képesség javulása a növelte a GDP-t, résztételeit és foglalkoztatást: Ezen hipotézisünket az impulzusválaszok alátámasztották, azonban azt fontos megjegyezni, hogy a hitelezési képesség nem a hitelezésen, hanem az országkockázat javulásán keresztül javítja a GDP-t.

- Hitelezési hajlandósági sokk hatására nốtt a hitelállomány és a GDP is: Ezt a várakozásunkat alátámasztották az impulzusválaszok. Eredményeink összhangban vannak Tamási és Világi (2011)-es cikkével, nagyságrendileg is hasonló hatást kaptunk.

- A vállalati hitelkamatok az alapkamat változását követték, a háztartási hitelkamatok nem csökkentek hajlandósági sokk esetén: A vállalati hitelpiacot erôs, míg a háztartási hitelpiacot gyenge verseny jellemezte (ahogy az értekezés előző fejezetében is megállapítottuk), valamint a vállalati hitelkamatok kamatozása referenciakamathoz kötött, míg a háztartási hiteleket a mintánk nagy részében változtatható kamatozás jellemezte. Ebból kifolyólag a vállalati kamatok követték az alapkamat változását, a háztartási hitelpiacon a hitelkínálat növekedése pedig a kockázatosabb adósok bevonásával történt, nem a kamatok csökkentésével (Király és Nagy (2008)). Ezt a hipotézist is alátámasztották eredményeink.

- A hitelezési képességi sokkok hatása perzisztensebb, míg a hajlandósági sokkok hatása elsôsorban rendkívüli eseményekhez köthetô és hamar lecseng: Erre vonatkozóan nem volt elôzetes várakozásunk, vagy szakirodalmi előzmény.

- A monetáris politika a válság után növekvô mértékben vette figyelembe a pénzügyi stabilitást: Erre vonatkozólag nem volt elôzetes várakozásunk, eredményünk újdonság a szakirodalomban.

- A válság elôtt a devizahitelezés idôszakában túlzott hitelkiáramlás, míg a válság után hitelszưke jellemezte a magyar bankrendszert. Ezen hipotézisünket az új módszertannal számított PKI-mutatónk alátámasztotta. Eredményünk összhangban áll Hosszú et al. (2016) cikk eredményeivel. 
- Áttérve a PD és PTI kapcsolatát vizsgáló fejezetre, előzetesen azt a hipotézist fogalmaztuk meg, hogy a háztartás munkapiaci és jövedelmi helyzete, eladósodottsága, fogyasztási kiadásai, a hitel denominációja és közvetítô részvétele a hitelügyletben hatással van a PD-re. Ez a hipotézisünk igaznak is bizonyult, találtunk olyan változókat, amelyek érdemi magyarázóerôvel rendelkeznek a PD-becslésben, és az említett hatásokat ragadják meg. A szignifikáns változók csoportja a releváns külföldi szakirodalomban találhatóval egybecseng. A denomináció kiemelt fontossága ugyanakkor magyar sajátosság.

- Arra is számítottunk, hogy szignifikáns változó lesz a jelzáloghitel típusa (lakás vagy szabadfelhasználású), a kibocsátás idôszaka, a megtakarítások nagysága, a hitel LTV-je, a háztartás iskolai végzettsége. Ez a hipotézisünk azonban nem bizonyult igaznak. Megállapítottuk azonban, hogy ezen változók korrelációját a PD-vel a becslésben szereplô változók megmagyarázzák, például a szabadfelhasználású hitelek azért voltak kockázatosabbak, mert a háztartások magasabb eladósodásával párosultak.

- A harmadik modellünkhöz tartozó hipotéziseink a következók voltak: A magyar bankrendszer költséghatékonyság szempontjából homogén és magas hatékonyság jellemzi, profithatékonyság tekintetében viszont heterogén. Erre vonatkozólag nem volt elôzetes várakozásunk, mivel a szakirodalom vegyes eredményeket mutatott be, attól függően, hogy milyen mintán vizsgálták a költséghatékonyságot. Profithatékonysági becslés a magyar bankrendszerre ezidág nem készült, ez újdonság az irodalomban. Az általáunk definiált szempontok szerint, a profithatékonysági becslések kicsivel jobban teljesítettek.

- Az SFA és a DEA modellek meglehetôsen eltérô eredményre vezetnek, a konkrét kérdéstôl függ, mely módszer alkalmasabb a hatékonyság mérésére. Ilyen összehasonlítás még nem készült a magyar bankrendszerre, ez is új eredménynek számít, ugyanakkor más mintán végzett kutatások szintén arra az eredményre jutottak, hogy a két modellcsalád használata eltérố eredményekhez vezet. 
- A válság a költséghatékonyságra pozitív, a profithatékonyságra negatív hatást gyakorolt. Ez az eredmény is újdonságnak számít magyar adatokon, ráadásul várakozásainknak megfelelő választ kaptunk. Egyedi banki adatokon megfigyelhetô, hogy a bankok tevékenységük racionalizálásával - például a fiókok számának csökkentésével - reagáltak a válságra, amely javította a költséghatékonyságot. Ugyanakkor a realizálódó magas hitelezési veszteségek nagy mértékben rontották a profitabilitást, amelyek kifutásával lassan a pofithatékonyság is javulni kezdett.

- A Lerner-indexek alapján a háztartási hitelpiacot magas piaci erố és gyenge verseny, míg a vállalati hitelpiacot intenzív, sốt, bizonyos időszakokban túlzott verseny jellemezte. Újdonság az irodalomban, hogy külön vizsgáltuk a háztartási és a vállalati hitelpiacot, mivel előzetes hipotézisünk az volt, hogy ezeken különbözô lehet a verseny intenzitása. Ezt alá is támasztották becsült Lerner-indexeink, amelyek a forrásköltségekhez viszonyított kamatfelárakhoz hasonló eredményre vezettek.

- A végtörlesztés gyengítette, míg az NHP javította a hitelezési hajlandóságot, a bankok piaci erejét mindkét intézkedés erôsítette. Ezen a hipotéziseket a PKI ás a Lerner-indexek alátámasztották és kölcsönösen megerôsítették.

Végezetül a modelljeinkból levonható, szabályozói szempontból fontos következtetéseket emeljük ki. A faktormodell alapján először is, a hitelezési aktivitás kapcsán az anyabank tôkehelyzete fontosabbnak bizonyult a leánybankinál, így vélhetôen a magyar tôkeszabályok változtatásának a magyar bankrendszerben kisebb a hatása, mint egy általános, európai szintû szabályváltoztatásnak. A PKI alapján a válság elôtti idôszakot túlzott hitelezés jellemezte, így szükség lett volna a bankrendszer hitelezési aktivitását (elsôsorban kockázatvállalását) korlátozó intézkedésre. A válság után azonban a hitelezést támogató intézkedések (mint például az NHP, melynek hatására javult is a mutató) váltak szükségessé a PKI által is jelzett hitelszúke miatt. A PD-modell arra adott egyfajta választ, hogy a válság előtt a jövedelemarányos törlesztőrészlet maximalizálásával hogyan lett volna érdemes korlátozni a hitelezést. Eszerint külön kellett volna mutatót előírni a devizában, 
illetve forintban denominált hitelekre, illetve jövedelem szerint is érdemes lett volna differenciálni. A különböző hatékonysági modellekkel kapott eltérô eredmények azt jelzik, érdemes többfajta modellbecslést végezni a robusztusabb következtetések érdekében. A Lerner-indexek alapján a háztartási hitelpiacon gyenge verseny volt tapasztalható a megfigyelt idôszakban, míg a vállalati hiteleknél túlzott kockázatvállalás jellemezte a bankokat. Szabályozói szempontból a nagy piaci erố és a túlzott verseny is indokolhatja a beavatkozást. 
A magyar bankrendszer makroprudenciális szempontból 


\section{Hivatkozások}

ACzél, A., A. BAnAi, A. Borsos és B. DAnCsik (2016), „A lakáshitelek felárát meghatározó tényezok azonosítása a magyar bankrendszerben”, $H i$ telintézeti Szemle, vol. 15, no. 4, pp. 5-44.

Aigner, D., C. Lovell és P. Schmidt (1977), „Formulation and estimation of stochastic frontier production function models", Journal of Econometrics, vol. 6, no. 1, pp. 21-37.

BAI, J. és S. NG (2002), „Determining the Number of Factors in Approximate Factor Models", Econometrica, vol. 70, no. 1, pp. 191-221.

BAI, J. és S. NG (2007), „Determining the Number of Primitive Shocks in Factor Models", Journal of Business \& Economic Statistics, vol. 25, pp. $52-60$.

BALÁs, T. (2013), „A háztartások eladósodottsága és jövedelemarányos törlesztési terhe", MNB-szemle, p. 23-28.

BalÁs, T., A. BAnAi és Z. Hosszú (2015), „Modelling probability of default and optimal PTI level by using a household survey", Acta Oeconomica, vol. 65, no. 1, pp. 183-210.

BANAI, A. (2016), „A banki hitelezést meghatározó tényezők - középpontban a bankok helyzete és a makrokörnyezet”, Közgazdasági Szemle, vol. 63, no. 2, pp. 137-161.

Banai, A., Z. Hosszú, G. Körmendi, S. Sóvágó és R. Szegedi (2013), „Stressztesztek a Magyar Nemzeti Bank gyakorlatában”, MNBtanulmányok 109, Magyar Nemzeti Bank. 
Banai, A., J. KirÁly és M. NAGY (2010), „Az aranykor vége Magyarországon. "Külföldi" és "lokális" bankok - válság elött és válság után", Közgazdasági Szemle, vol. 0, no. 2, pp. 105-131.

Basso, H. S., O. Calvo-Gonzalez és M. Jurgilas (2011), „Financial dollarization: The role of foreign-owned banks and interest rates", Journal of Banking \& Finance, vol. 35, no. 4, pp. 794 - 806, crete Conference 2010: The Future of Universal Banking.

Bauer, P. W., A. N. Berger, G. D. Ferrier és D. B. Humphrey (1998), „Consistency Conditions for Regulatory Analysis of Financial Institutions: A Comparison of Frontier Efficiency Methods", Journal of Economics and Business, vol. 50, no. 2, pp. 85-114.

Beaton, K., R. Lalonde és C. Luu (2009), „A Financial Conditions Index for the United States", Discussion Papers 09-11, Bank of Canada.

Bernanke, B., J. Boivin és P. S. Eliasz (2005), „Measuring the Effects of Monetary Policy: A Factor-augmented Vector Autoregressive (FAVAR) Approach", The Quarterly Journal of Economics, vol. 120, no. 1, pp. 387422.

Bethlendi, A. (2007), „A hazai bankok hitelezésiveszteség-elszámolásának vizsgálata", Közgazdasági Szemle, vol. 54, no. 1, pp. 67-93.

Blanco, R. és R. Gimeno (2012), „Determinants of default ratios in the segment of loans to households in Spain", Working Paper 1210, Banco de Espana.

Bodnár, I., S. Hegedüs, A. Plajner és G. Pullai (2017), „Célzott hitelösztönzés: NHP-tól az NTP-ig", in: K. Lehmann, D. Palotai és B. Virág (szerk.), A magyar út - célzott jegybanki politika, Magyar Nemzeti Bank, Budapest.

Boivin, J., M. Giannoni és D. Stevanovic (2013), „Dynamic effects of credit shocks in a data-rich environment", Staff Reports 615, Federal Reserve Bank of New York. 
Borio, C. és I. Shim (2007), "What can (macro-)prudential policy do to support monetary policy?", Working Paper 242, Bank for International Settlements.

Brave, S. és R. A. Butters (2011), „Monitoring financial stability: a financial conditions index approach", Economic Perspectives, p. 22-43.

Buch, C. M., S. Eickmeier és E. Prieto (2014), „Macroeconomic Factors and Microlevel Bank Behavior", Journal of Money, Credit and Banking, vol. 46, no. 4, pp. $715-751$.

Casu, B., C. Girardone és P. Molyneux (2004), „Productivity change in European banking: A comparison of parametric and non-parametric approaches", Journal of Banking $\&$ Finance, vol. 28, no. 10, pp. 2521-2540.

Charnes, A., W. W. Cooper és E. Rhodes (1978), „Measuring the efficiency of decision making units", European Journal of Operational Research, vol. 2, no. 6, pp. 429-444.

Cogley, T. és T. J. Sargent (2005), „Drift and Volatilities: Monetary Policies and Outcomes in the Post WWII U.S", Review of Economic Dynamics, vol. 8, no. 2, pp. 262-302.

DANCsik, B. és Z. Hosszú (2017), „Banki hatékonyság és piaci erô mérése a háztartási és a vállalati hitelpiacon a hitelezési kockázatok figyelembevétele mellett", MNB-tanulmányok 133, Magyar Nemzeti Bank.

Darracq Pariès, M., L. Maurin és D. Moccero (2014), „Financial conditions index and credit supply shocks for the euro area", Working Paper Series 1644, Európai Központi Bank.

Del Negro, M. és C. Otrok (2008), „Dynamic factor models with timevarying parameters: measuring changes in international business cycles", Staff Reports 326, Federal Reserve Bank of New York.

Delis, M., A. Koutsomanoli-Fillipaki, C. Staikouras és G. Katerina (2009), „Evaluating cost and profit efficiency: a comparison of parametric and nonparametric methodologies", Applied Financial Economics, vol. 19, no. 3, pp. 191-202. 
A magyar bankrendszer makroprudenciális szempontból

DiAllo, B. (2017), „Bank efficiency and industry growth during financial crises", Economic Modelling, p. -.

Dong, Y., R. Hamilton és M. Tippett (2014), „Cost efficiency of the Chinese banking sector: A comparison of stochastic frontier analysis and data envelopment analysis", Economic Modelling, vol. 36, pp. 298 - 308.

Doz, C., D. Giannone és L. Reichlin (2011), „A two-step estimator for large approximate dynamic factor models based on Kalman filtering", Journal of Econometrics, vol. 164, no. 1, pp. 188-205.

Doz, C., D. Giannone és L. Reichlin (2012), „A Quasi-Maximum Likelihood Approach for Large, Approximate Dynamic Factor Models", The Review of Economics and Statistics, vol. 94, no. 4, pp. 1014-1024.

Drake, L. és T. G. Weyman-Jones (1996), „Productive and Allocative Inefficiencies in U.K. Building Societies: A Comparison of Non-parametric and Stochastic Frontier Techniques", The Manchester School of Economic E Social Studies, vol. 64, no. 1, pp. 22-37.

Eickmeier, S., W. Lemke és M. Marcellino (2011a), „Classical timevarying FAVAR models - estimation, forecasting and structural analysis", Discussion Paper Series 1: Economic Studies 2011,04, Deutsche Bundesbank, Research Centre.

Eickmeier, S., W. Lemke és M. MARCELlino (2011b), „The changing international transmission of financial shocks: evidence from a classical timevarying FAVAR", Discussion Paper Series 1: Economic Studies 2011,05, Deutsche Bundesbank, Research Centre.

Eisenbeis, R. A., G. D. Ferrier és S. H. Kwan (1999), „The informativeness of stochastic frontier and programming frontier efficiency scores: Cost efficiency and other measures of bank holding company performance", FRB Atlanta Working Paper 99-23, Federal Reserve Bank of Atlanta.

EKB (2009), „A global index of financial turbulence”, Financial stability Review December, Európai Központi Bank. 
Ferrier, G. és C. Lovell (1990), „Measuring cost efficiency in banking: Econometric and linear programming evidence", Journal of Econometrics, vol. 46, no. 1-2, pp. 229-245.

FrIES, S. és A. TACI (2005), „Cost efficiency of banks in transition: Evidence from 289 banks in 15 post-communist countries", Journal of Banking \& Finance, vol. 29, no. 1, pp. 55-81.

GÁSPÁR, K. és Z. VARGA (2011), „A bajban lévô lakáshitelesek elemzése mikroszimulációs modellezéssel", Közgazdasági Szemle, vol. 58, pp. 529542.

GEWEKE, J. F. (1977), „The dynamic factor analysis of economic time series”, in: D. Aigner és A. Goldberger (szerk.), Latent Variables in Socioeconomic Models, p. 365-383, North-Holland.

Greene, W. (2005), „Reconsidering heterogeneity in panel data estimators of the stochastic frontier model", Journal of Econometrics, vol. 126, no. 2, pp. 269-303.

Gulati, R. és S. Kumar (2016), „Assessing the impact of the global financial crisis on the profit efficiency of Indian banks", Economic Modelling, vol. 58, no. C, pp. 167-181.

Hatzius, J., P. Hooper, F. S. Mishkin, K. L. Schoenholtz és M. W. WAtson (2010), „Financial Conditions Indexes: A Fresh Look after the Financial Crisis", NBER Working Papers 16150, National Bureau of Economic Research, Inc.

HavrylchyK, O. (2006), „Efficiency of the Polish banking industry: Foreign versus domestic banks", Journal of Banking $\mathscr{E}$ Finance, vol. 30, no. 7, pp. $1975-1996$.

Holló, D. (2009), „Kockázatalakulás a lakossági jelzáloghitelek piacán”, MNB-szemle, p. 13-18.

Holló, D. és M. PAPP (2007), „A háztartási hitelkockázat becslése: egy kérdôíves felmérés tanulságai", MNB-tanulmányok 70, Magyar Nemzeti Bank. 
Hosszú, Z. (2018), „The impact of credit supply shocks and a new Financial Conditions Index based on a FAVAR approach", Economic Systems, vol. 42, no. 1 , pp. $32-44$.

Hosszú, Z. (2011), „A lakosság fogyasztási viselkedése és annak jövedelem szerinti heterogenitása a válság előtt mikrostatisztikák alapján", MNB-szemle, p. 28-35.

Hosszú, Z., G. KÖrmendi és B. MÉRÕ (2016), „Egy- és többváltozós szürôk a hitelrés alakulásának meghatározására”, Közgazdasági Szemle, vol. 63, pp. 233-259.

Huang, T.-H. és M.-H. WAng (2002), „Comparison of Economic Efficiency Estimation Methods: Parametric and Non-parametric Techniques", Manchester School, vol. 70, no. 5, pp. 682-709.

IMF (2008), „Financial Stress and Economic Downturns”, World Economic Outlook October, International Monetary Fund.

Jimborean, R. és J.-S. MÉsonnier (2010), „Banks' Financial Conditions and the Transmission of Monetary Policy: A FAVAR Approach", International Journal of Central Banking, vol. 6, no. 34, pp. 71-117.

KÉZDI, G. és G. CsorbA (2012), „Estimating consumer lock-in effects from firm-level data", CEU Working Papers 2012/17, Department of Economics, Central European University.

KirÁly, J. és A. BANAi (2012), „A „flow” és a „stock” árnyalatai (gazdasági esszé a devizahitelezés kapcsán)", in: M. László (szerk.), Feldobott kô? Tények és tendenciák a 21. században, Akadémia Kiadó.

KIRÁLY, J. és M. NAGY (2008), „Jelzálogpiacok válságban: kockázatalapú verseny és tanulságok", Hitelintézeti Szemle, vol. 7, no. 5, pp. 450-482.

Koop, G. és D. KorobiLis (2013), „Large time-varying parameter VARs”, Journal of Econometrics, vol. 177, no. 2, pp. 185-198.

Koop, G. és D. Korobilis (2014), „A new index of financial conditions”, European Economic Review, vol. 71, no. C, pp. 101-116. 
Korobilis, D. (2013), „Assessing the Transmission of Monetary Policy Using Time-varying Parameter Dynamic Factor Models", Oxford Bulletin of Economics and Statistics, vol. 75, no. 2, pp. 157-179.

Koutsomanoli-Filippaki, A., D. Margaritis és C. Staikouras (2009), „Efficiency and productivity growth in the banking industry of Central and Eastern Europe", Journal of Banking \& Finance, vol. 33, no. 3, pp. $557-567$.

LaCAva, G. és J. Simon (2003), „A Tale of Two Surveys: Household Debt and Financial Constraints in Australia", Research Discussion Paper 2003/08, Reserve Bank of Australia.

Lerner, A. P. (1934), ,The Concept of Monopoly and the Measurement of Monopoly Power", Review of Economic Studies, vol. 1, no. 3, pp. 157-175.

Lyndon, R. és Y. MCCARThy (2013), „What Lies Beneath? Understanding Recent Trends in Irish Mortgage Arrears", The Economic and Social Review, Economic and Social Studies, vol. 44, no. 1, pp. 117-150.

Matheson, T. D. (2012), „Financial conditions indexes for the United States and euro area", Economics Letters, vol. 115, no. 3, pp. 441-446.

May, O. és M. Tudela (2005), „When is Mortgage Indebtedness a Financial Burden to British Households? A Dynamic Probit Approach", Working Paper 27\%, Bank of England.

Meeusen, W. és J. VAn den Broeck (1977), „Efficiency Estimation from Cobb-Douglas Production Functions with Composed Error", International Economic Review, vol. 18, no. 2, pp. 435-44.

Mian, A. R. és A. Sufi (2011), „House Prices, Home Equity-Based Borrowing, and the U.S. Household Leverage Crisis", American Economic Review, vol. 101, no. 5, pp. 2132-2156.

MNB (2011), „Pénzügyi Stabilitási Jelentés”, Jelentés 2011. november, Magyar Nemzeti Bank.

MNB (2014), „3-as és 6-os keretes írás”, Pénzügyi Stabilitási Jelentés 2014. november, Magyar Nemzeti Bank. 
A magyar bankrendszer makroprudenciális szempontból

MNB (2016), „Pénzügyi Stabilitási Jelentés”, Jelentés 2016. május, Magyar Nemzeti Bank.

MNB (2017), „Pénzügyi Stabilitási Jelentés”, Jelentés 2017. május, Magyar Nemzeti Bank.

Moench, E., S. NG és S. Potter (2013), „Dynamic Hierarchical Factor Model", The Review of Economics and Statistics, vol. 95, no. 5, pp. 18111817.

Molnár, J., M. NAGy és C. Horváth (2007), „A Structural Empirical Analysis of Retail Banking Competition: the Case of Hungary", MNB Working Papers 2007/1, Magyar Nemzeti Bank.

Molnár, M. és D. Holló (2011), „How Efficient Are Banks in Hungary?”, OECD Economics Department Working Papers 848, OECD Publishing.

Móré, C. és M. NAGy (2003), „Relationship between Market Structure and Bank Performance: Empirical Evidence for Central and Eastern Europe", MNB Working Papers 2003/12, Magyar Nemzeti Bank.

Móré, C. és M. NAGy (2004), „Competition in the Hungarian Banking Market", MNB Working Papers 2004/9, Magyar Nemzeti Bank.

Nitoi, M. és C. Spulbar (2015), „An Examination of Banks' Cost Efficiency in Central and Eastern Europe", Procedia Economics and Finance, vol. 22, pp. $544-551$.

NurbojA, B. és M. Kosak (2017), „Banking efficiency in South East Europe: Evidence for financial crises and the gap between new EU members and candidate countries", Economic Systems, vol. 41, no. 1, pp. 122 - 138.

Pellényi, G. (2012), „,The Sectoral Effects of Monetary Policy in Hungary: A Structural Factor Analysis", MNB Working Papers 2012/1, Magyar Nemzeti Bank.

Prieto, E., S. Eickmeier és M. Marcellino (2013), „Time variation in macro-financial linkages", Discussion Papers 13/2013, Deutsche Bundesbank, Research Centre. 
Resti, A. (1997), „Evaluating the cost-efficiency of the Italian Banking System: What can be learned from the joint application of parametric and non-parametric techniques", Journal of Banking \& Finance, vol. 21, no. 2, pp. 221-250.

Sargent, T. J. és C. A. Sims (1977), „Business cycle modeling without pretending to have too much a priori economic theory", Working Paper 55, Federal Reserve Bank of Minneapolis.

Stock, J. H. és M. W. Watson (2002), „Forecasting Using Principal Components from a Large Number of Predictors", Journal of the American Statistical Association, vol. 97, no. 460, pp. 1167-1179.

Swiston, A. (2008), „A U.S. Financial Conditions Index: Putting Credit Where Credit is Due", IMF Working Papers 08/161, International Monetary Fund.

TAMÁsi, B. és B. VILÁGi (2011), „Identification of credit supply shocks in a Bayesian SVAR model of the Hungarian economy", MNB Working Papers 2011/7, Magyar Nemzeti Bank.

TONE, K. (2002), „A strange case of the cost and allocative efficiencies in DEA", Journal of the Operational Research Society, vol. 53, no. 11, pp. 1225-1231.

WANG, H.-J. (2002), „Heteroscedasticity and non-monotonic efficiency effects of a stochastic frontier model", Mpra paper, University Library of Munich, Germany.

WeILl, L. (2004), „Measuring Cost Efficiency in European Banking: A Comparison of Frontier Techniques", Journal of Productivity Analysis, vol. 21, no. 2, pp. 133-152.

Zettelmeyer, J., P. M. NAgy és S. Jeffrey (2010), „Addressing private sector currency mismatches in emerging Europe", Working Paper 115, EBRD. 
A magyar bankrendszer makroprudenciális szempontból 


\section{A Függelék: a faktormodellel kapcsolatos kiegészítô információk}

5.1. táblázat: Makrogazdasági idôsorok

\begin{tabular}{|l|c|c|c|}
\hline Változó & Deflálás & Transzf. & Szez. ig. \\
\hline Háztartások nettó fogyasztási kiadásai & reál & növ.ráta & igen \\
\hline Kormányzati fogyasztás & reál & növ. ráta & igen \\
\hline Háztartások ingatlanberuházása & reál & növ. ráta & igen \\
\hline Vállalatok állóeszköz-beruházása & reál & növ. ráta & igen \\
\hline Kormányzati beruházás & reál & növ. ráta & igen \\
\hline Állóeszköz-beruházás & reál & növ. ráta & igen \\
\hline Export & reál & növ. ráta & igen \\
\hline Import & reál & növ. ráta & igen \\
\hline GDP & reál & növ. ráta & igen \\
\hline Ipari termelés & reál & növ. ráta & igen \\
\hline Feldolgozóipar & reál & növ. ráta & igen \\
\hline LFS létszám, nemzetgazdaság & reál & növ. ráta & igen \\
\hline LFS létszám, versenyszféra & reál & növ. ráta & igen \\
\hline Rendelkezésre álló jövedelem & reál & növ. ráta & igen \\
\hline Bizalmi indikátor: szolgáltatások & nominális & - & igen \\
\hline Bizalmi indikátor: ipar & nominális & - & igen \\
\hline Bizalmi indikátor: fogyasztás & nominális & - & igen \\
\hline
\end{tabular}


A magyar bankrendszer makroprudenciális szempontból

\begin{tabular}{|l|c|c|c|}
\hline Változó & Deflálás & Transzf. & Szez. ig. \\
\hline Bizalmi indikátor: kiskereskedelem & nominális & - & igen \\
\hline Bizalmi indikátor: építőipar & nominális & - & igen \\
\hline Maginfláció & nominális & - & igen \\
\hline Indirektadó-hatástól szúrt maginfláció & nominális & - & igen \\
\hline Infláció & nominális & - & igen \\
\hline Termelôi árindex & nominális & - & igen \\
\hline Államkötvényfelár & nominális & - & nem \\
\hline EUR/HUF árfolyam & nominális & logváltozás & nem \\
\hline 3-hónapos bankközi kamat & nominális & - & nem \\
\hline Vállalati hitelek kamata & nominális & - & nem \\
\hline Jelzáloghitelek kamata & nominális & - & nem \\
\hline Fogyasztási hitelek kamata & nominális & - & nem \\
\hline Teljes hitelállomány & nominális & növ. ráta & nem \\
\hline Vállalati hitelek állománya & nominális & növ. ráta & nem \\
\hline Jelzáloghitelek állománya & nominális & növ. ráta & nem \\
\hline Fogyasztási hitelek állománya & nominális & növ. ráta & nem \\
\hline FHB lakásárindex & nominális & növ. ráta & igen \\
\hline
\end{tabular}

5.2. táblázat: A makrogazdasági változókra és faktorokra futtatott regressziók $R^{2}-e i$

\begin{tabular}{|l|l|}
\hline Háztartások nettó fogyasztási kiadásai & 0.68 \\
\hline Kormányzati fogyasztás & 0.08 \\
\hline Háztartások ingatlanberuházása & 0.31 \\
\hline Vállalatok állóeszköz-beruházása & 0.23 \\
\hline Kormányzati beruházásberuházás & 0.26 \\
\hline Állóeszköz-beruházás & 0.28 \\
\hline Export & 0.75 \\
\hline
\end{tabular}




\begin{tabular}{|l|c|}
\hline Import & 0.60 \\
\hline GDP & 0.80 \\
\hline Ipari termelés & 0.82 \\
\hline Feldolgozóipar & 0.84 \\
\hline LFS létszám, nemzetgazdaság & 0.41 \\
\hline LFS létszám, versenyszféra & 0.40 \\
\hline Rendelkezésre álló jövedelem & 0.33 \\
\hline Bizalmi indikátor: ipar & 0.57 \\
\hline Bizalmi indikátor: szolgáltatások & 0.95 \\
\hline Bizalmi indikátor: fogyasztás & 0.86 \\
\hline Bizalmi indikátor: kiskereskedelem & 0.79 \\
\hline Bizalmi indikátor: építőipar & 0.87 \\
\hline Maginfláció & 0.74 \\
\hline Indirekt-adóhatásoktól szürt maginfláció & 0.58 \\
\hline Infláció & 0.78 \\
\hline Termelói árindex & 0.42 \\
\hline Államkötvényfelár & 0.75 \\
\hline EUR/HUF árfolyam & 0.57 \\
\hline 3-hónapos bankközi kamat & 0.90 \\
\hline Vállalati hitelek kamata & 0.92 \\
\hline Jelzáloghitelek kamata & 0.74 \\
\hline Fogyasztási hitelek kamata & 0.83 \\
\hline Teljes hitelállomány & 0.92 \\
\hline Vállalati hitelek állománya & 0.76 \\
\hline Jelzáloghitelek állománya & 0.80 \\
\hline Fogyasztási hitelek állománya & 0.95 \\
\hline FHB lakásárindex & 0.34 \\
\hline
\end{tabular}


5.1. ábra: A pénzügyi faktorok konfidenciaintervallumokkal

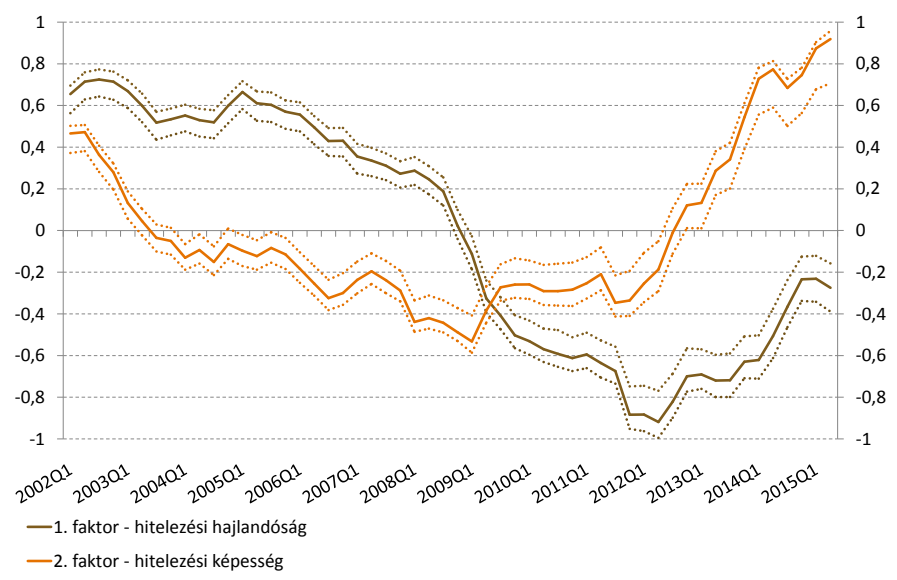

Megjegyzés: a folytonos vonalak a faktorokat, a szaggatott vonalak a 90 százalékos konfidenciaintervallumokat jelölik.

5.2. ábra: Az elsô és a második makrofaktor konfidenciaintervallumokkal

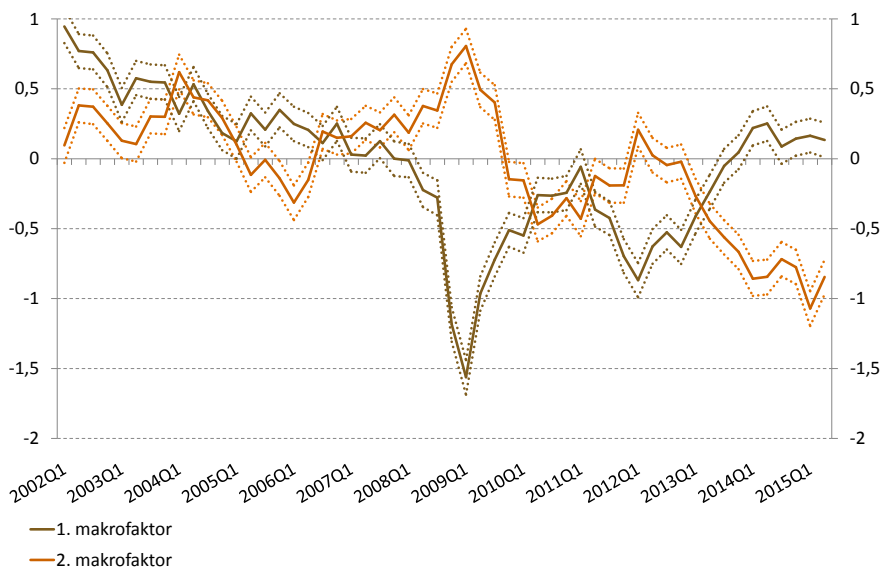

Megjegyzés: a folytonos vonalak a faktorokat, a szaggatott vonalak a 90 százalékos konfidenciaintervallumokat jelölik. 
5.3. ábra: A harmadik és a negyedik makrofaktor konfidenciaintervallumokkal

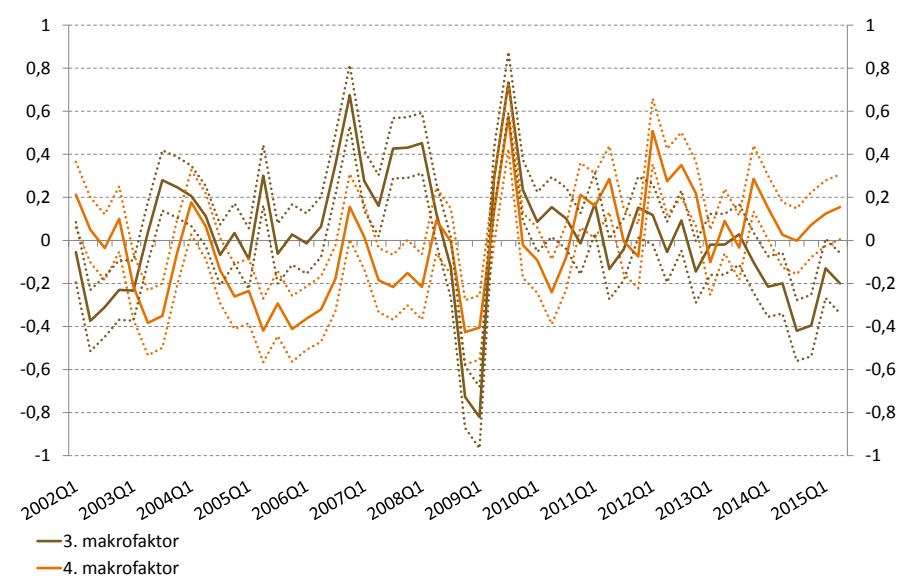

Megjegyzés: a folytonos vonalak a faktorokat, a szaggatott vonalak a 90 százalékos konfidenciaintervallumokat jelölik.

5.4. ábra: Pénzügyi faktorok robusztussága a becsült faktorok számára

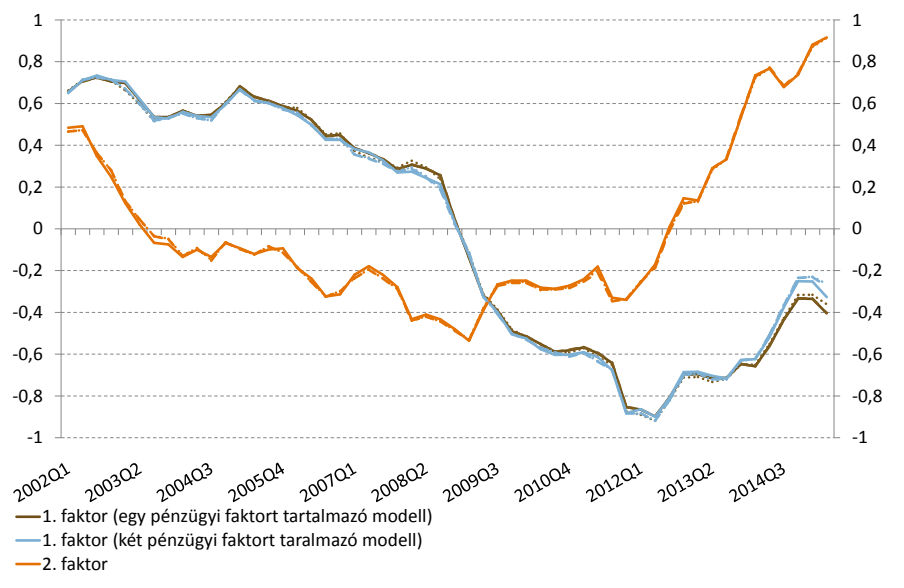

Megjegyzés: a folytonos vonalak jelölik a becsült pénzügyi faktorokat három makrofaktor, a szaggatott vonalak négy makrofaktor, a pontozott vonalak öt makrofaktor mellett. 
5.5. ábra: A makrofaktorok volatilitása

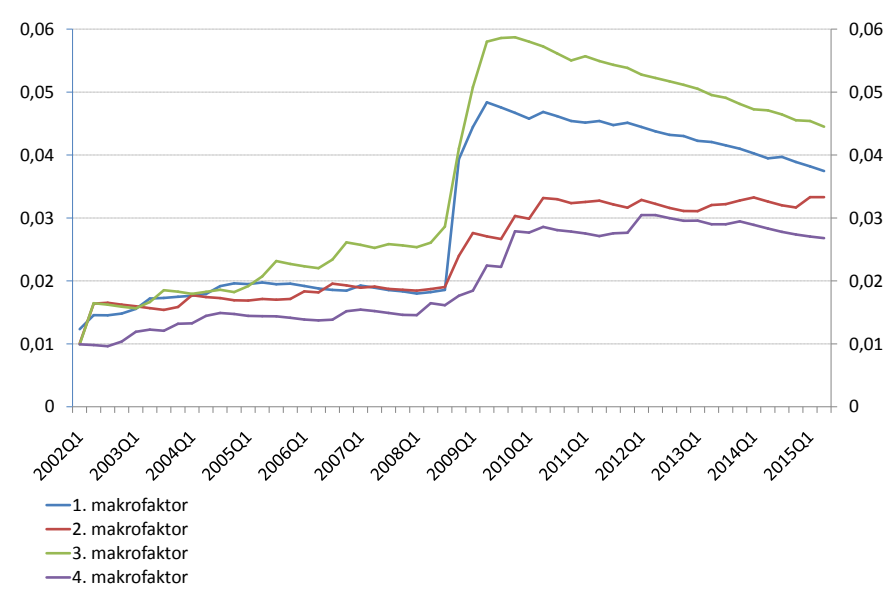


5.6. ábra: A makrofaktorok impulzusválaszai egy hitelezési hajlandósági sokk esetén
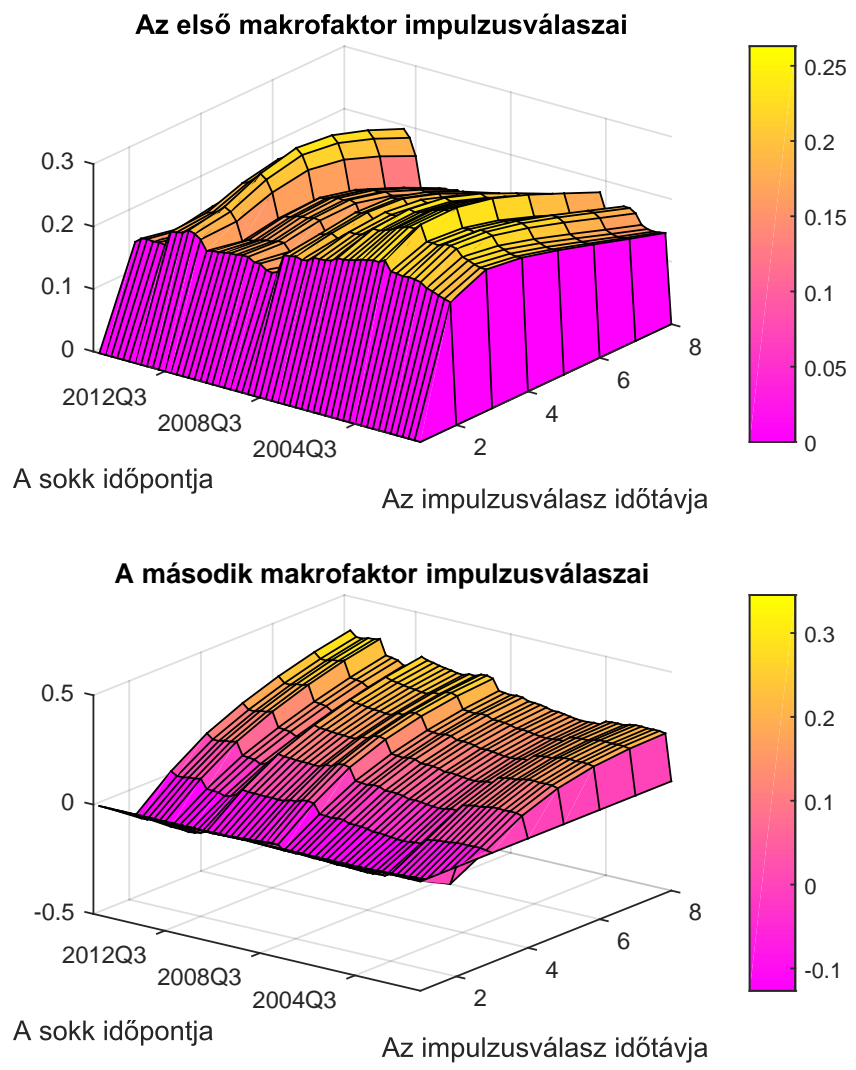
5.7. ábra: A makrofaktorok impulzusválaszai egy hitelezési hajlandósági sokk esetén
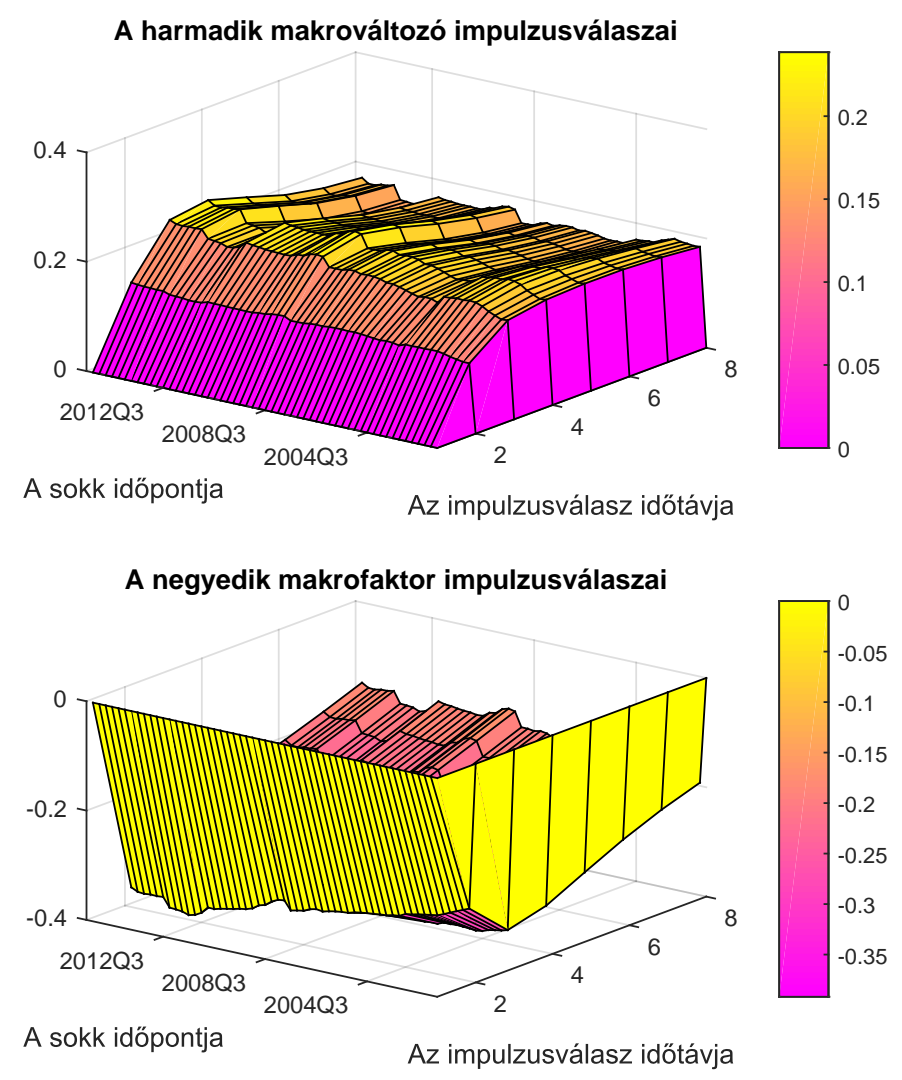
5.8. ábra: A makrofaktorok impulzusválaszai egy hitelezési képességi sokk esetén
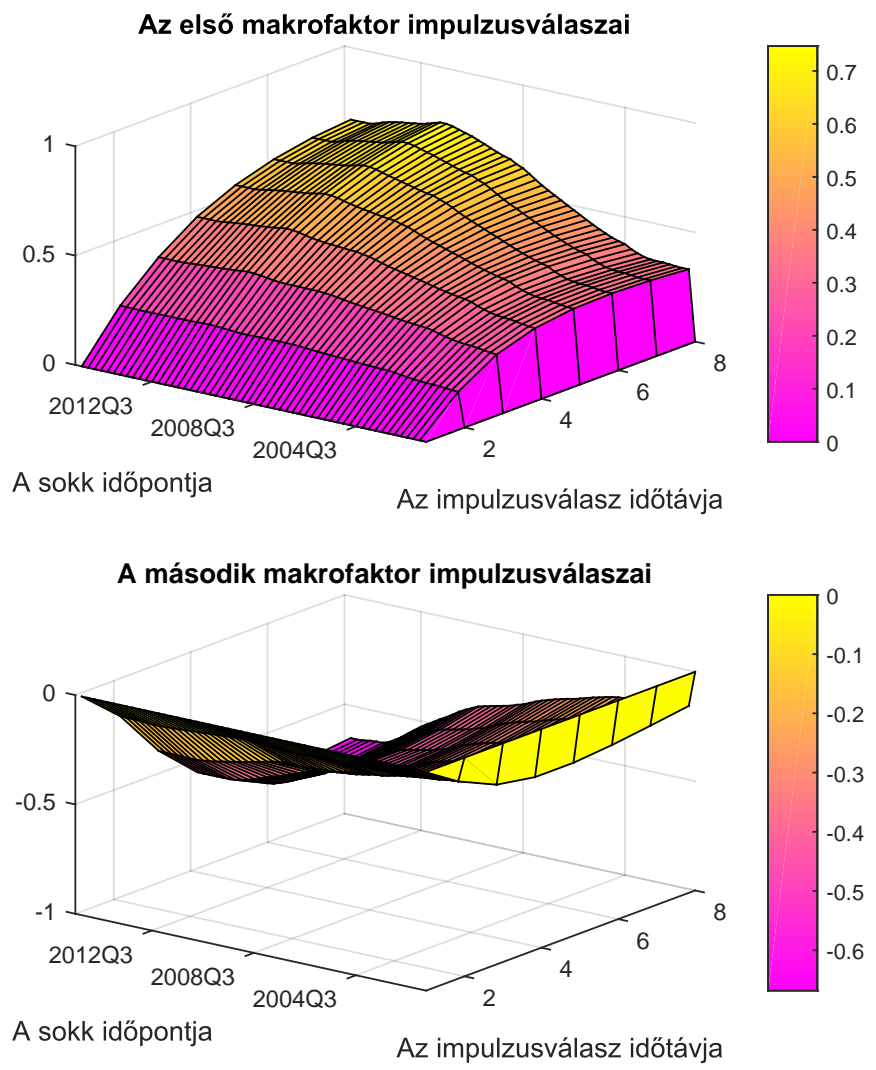
5.9. ábra: A makrofaktorok impulzusválaszai egy hitelezési képességi sokk esetén
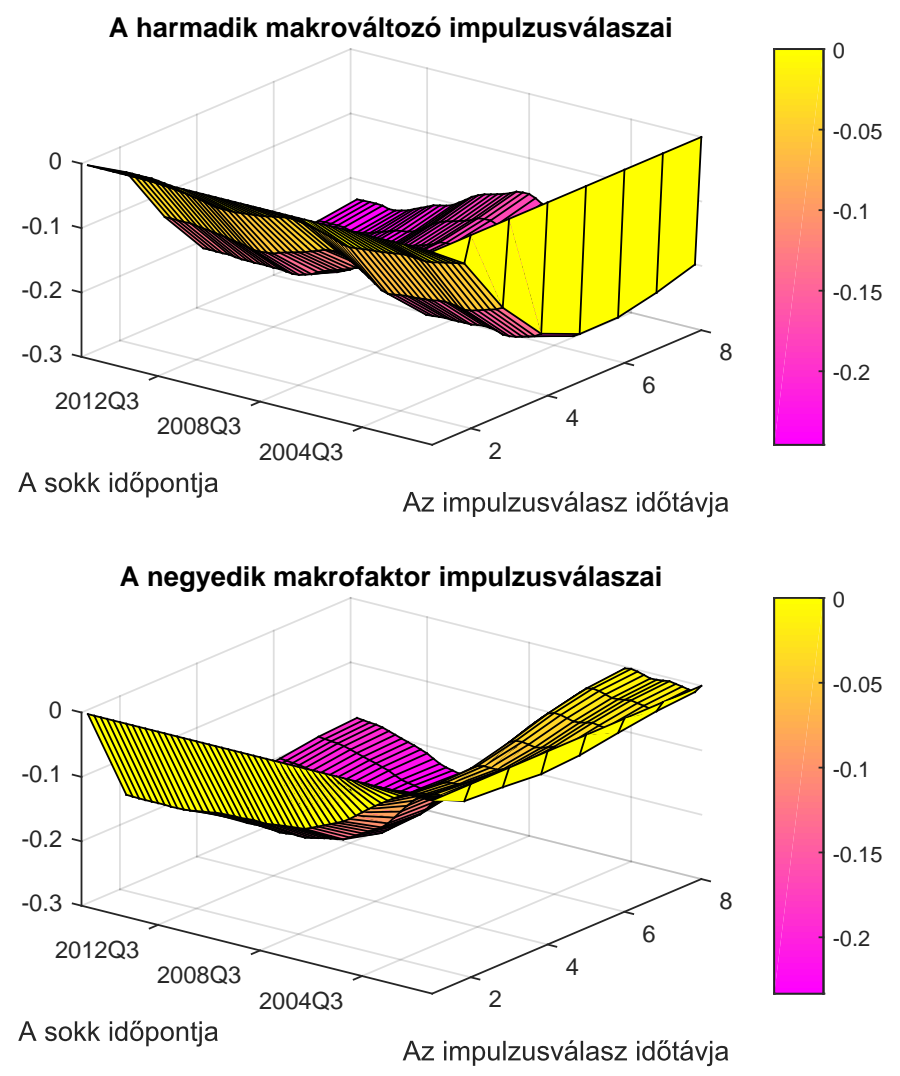
5.10. ábra: A hitelállományok- és kamatok impulzusválaszai egy hitelezési hajlandósági sokk esetén
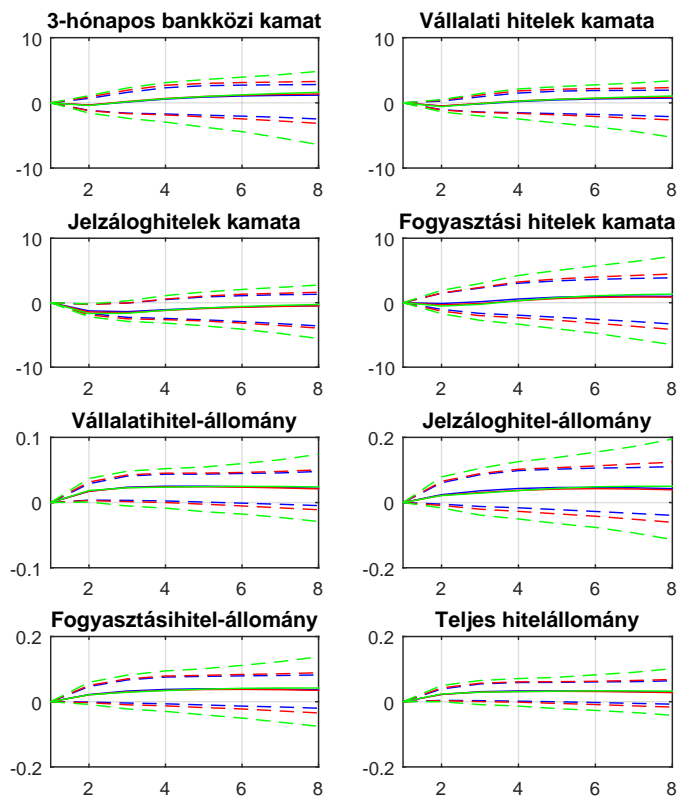

Megjegyzés: a folytonos vonalak jelölik az impulzusválaszokat (kék=2004q4, piros=2008q4, zöld=2013q4), a szaggatott vonalak jelölik a 70 százalékos konfidenciaintervallumokat. 
5.11. ábra: A fóbb GDP-tételek és az ipari termelés impulzusválaszai egy hitelezési hajlandósági sokk esetén
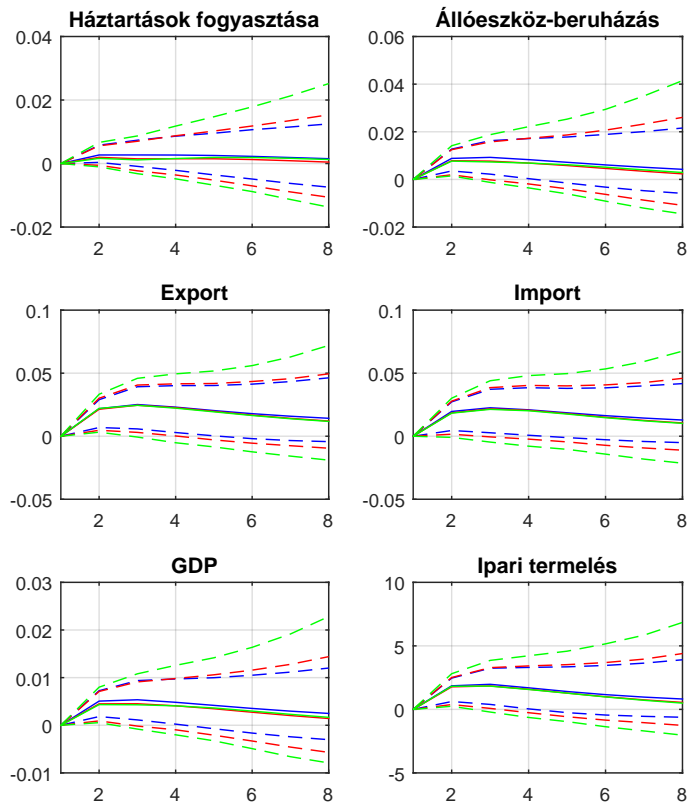

Megjegyzés: a folytonos vonalak jelölik az impulzusválaszokat (kék=2004q4, piros $=2008 q 4$, zöld=2013q4), a szaggatott vonalak jelölik a 70 százalékos konfidenciaintervallumokat. 
5.12. ábra: Foglalkoztatás, államkötvényfelár és árak impulzusválaszai egy hitelezési hajlandósági sokk esetén
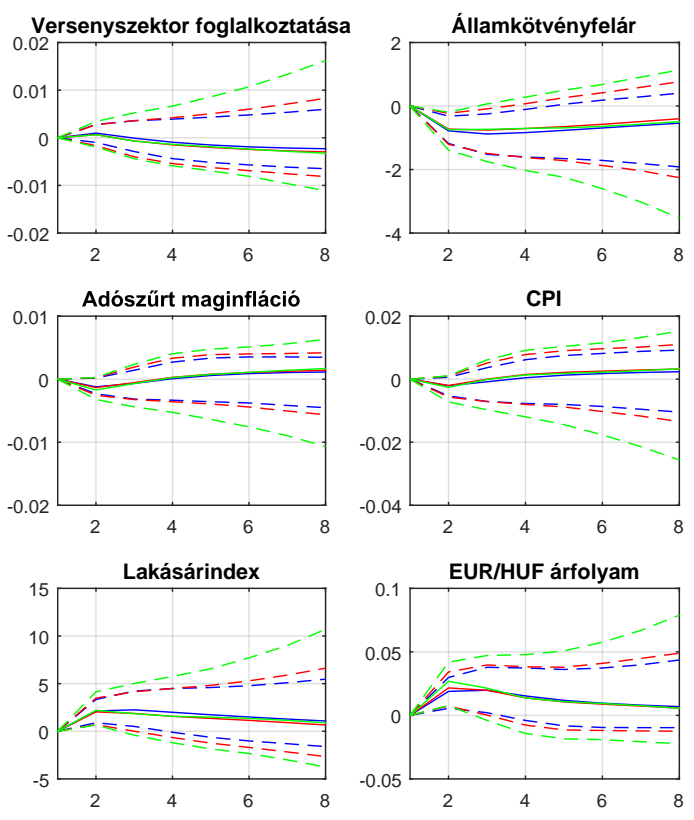

Megjegyzés: a folytonos vonalak jelölik az impulzusválaszokat (kék=2004q4, piros=2008q4, zöld=2013q4), a szaggatott vonalak jelölik a 70 százalékos konfidenciaintervallumokat. 
5.13. ábra: A hitelállományok- és kamatok impulzusválaszai egy hitelezési képességi sokk esetén
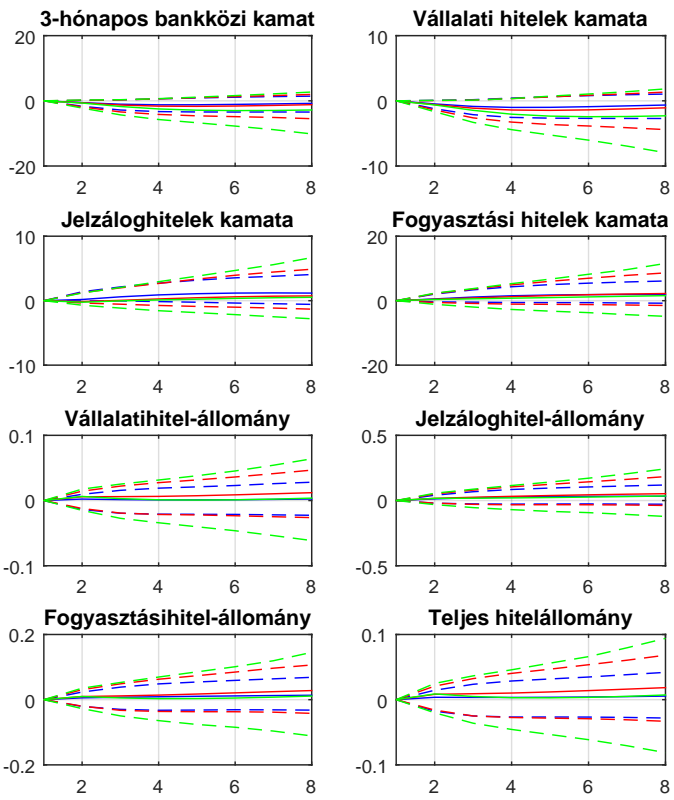

Megjegyzés: a folytonos vonalak jelölik az impulzusválaszokat (kék $=2004 q 4$, piros $=2008 q 4$, zöld=2013q4), a szaggatott vonalak jelölik a 70 százalékos konfidenciaintervallumokat. 
5.14. ábra: A főbb GDP-tételek és az ipari termelés impulzusválaszai egy hitelezési képességi sokk esetén
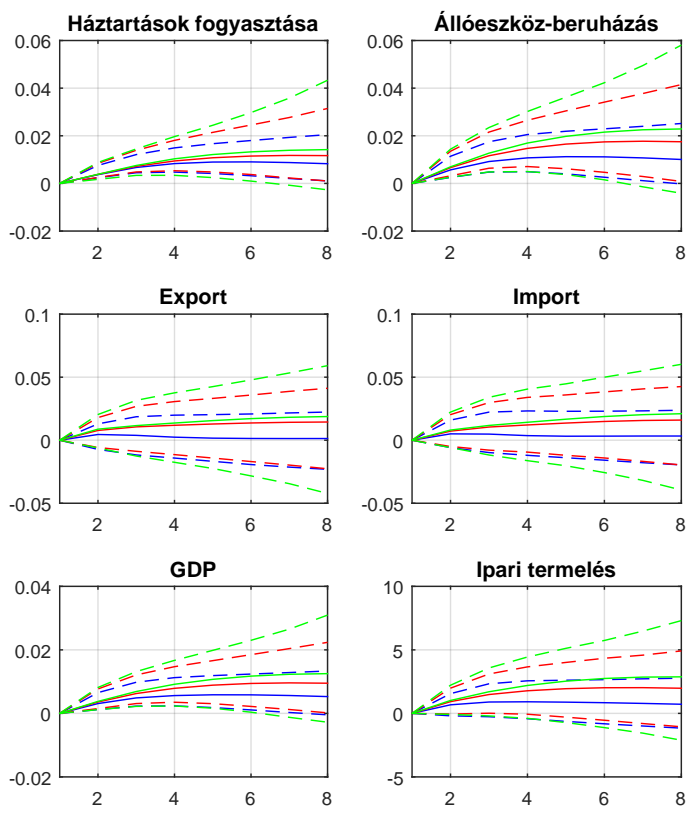

Megjegyzés: a folytonos vonalak jelölik az impulzusválaszokat (kék=2004q4, piros=2008q4, zöld=2013q4), a szaggatott vonalak jelölik a 70 százalékos konfidenciaintervallumokat. 
5.15. ábra: Foglalkoztatás, államkötvényfelár és árak impulzusválaszai egy hitelezési képességi sokk esetén
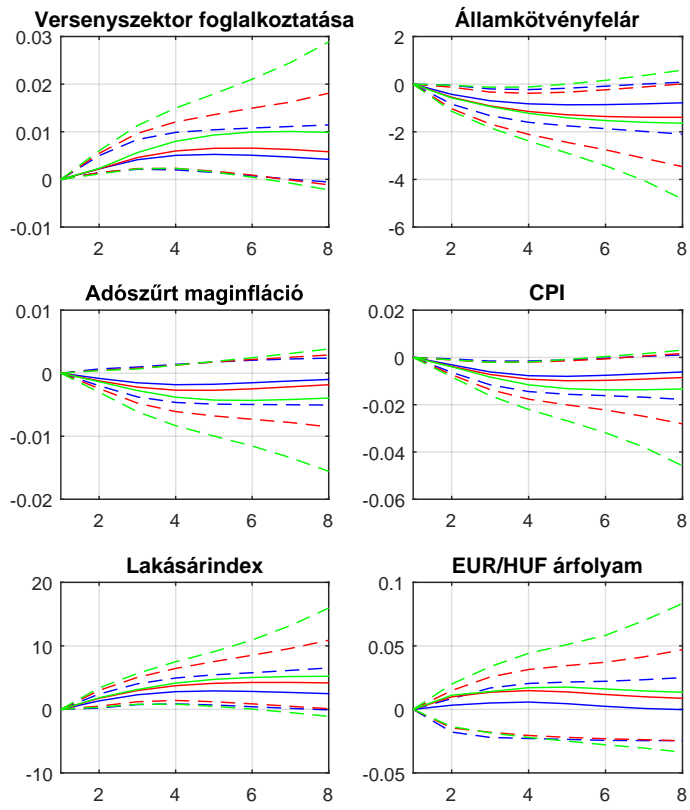

Megjegyzés: a folytonos vonalak jelölik az impulzusválaszokat (kék=2004q4, piros=2008q4, zöld=2013q4), a szaggatott vonalak jelölik a 70 százalékos konfidenciaintervallumokat. 
5.16. ábra: A hitelállományok- és kamatok impulzusválaszai egy hitelezési hajlandósági sokk esetén 2013 IV. negyedévében (robusztusság vizsgálat)
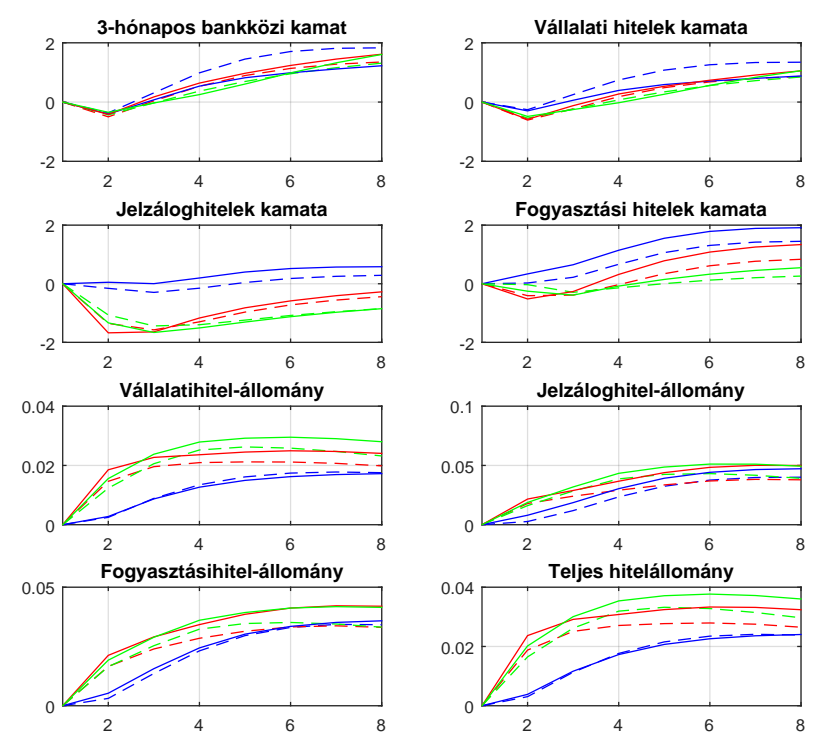

Megjegyzés: a folytonos vonalak jelölik a két pénzügyi faktorral, a szaggatott vonalak az egy pénzügyi faktorral kapott eredményeket (kék=három makrofaktor, piros=négy makrofaktor, zöld=öt makrofaktor). 
5.17. ábra: A foobb GDP-tételek és az ipari termelés impulzusválaszai egy hitelezési hajlandósági sokk esetén 2013 IV. negyedévében (robusztusság vizsgálat)
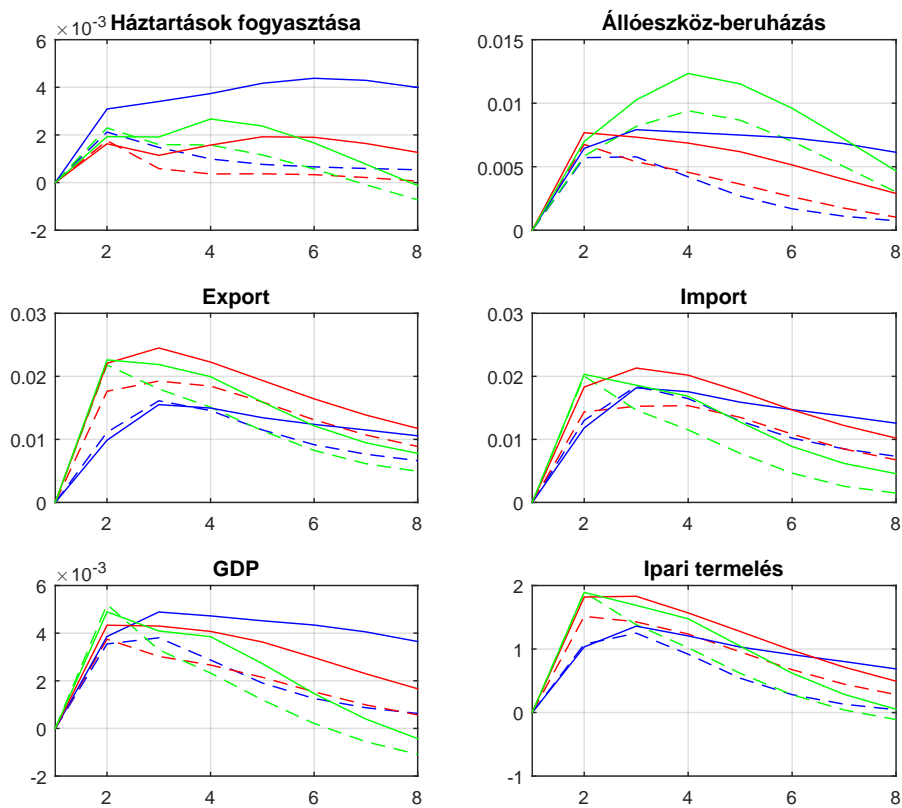

Megjegyzés: a folytonos vonalak jelölik a két pénzügyi faktorral, a szaggatott vonalak az egy pénzügyi faktorral kapott eredményeket (kék=három makrofaktor, piros=négy makrofaktor, zöld=öt makrofaktor). 
5.18. ábra: Foglalkoztatás, államkötvényfelár és árak impulzusválaszai egy hitelezési hajlandósági sokk esetén 2013 IV. negyedévében (robusztusság vizsgálat)
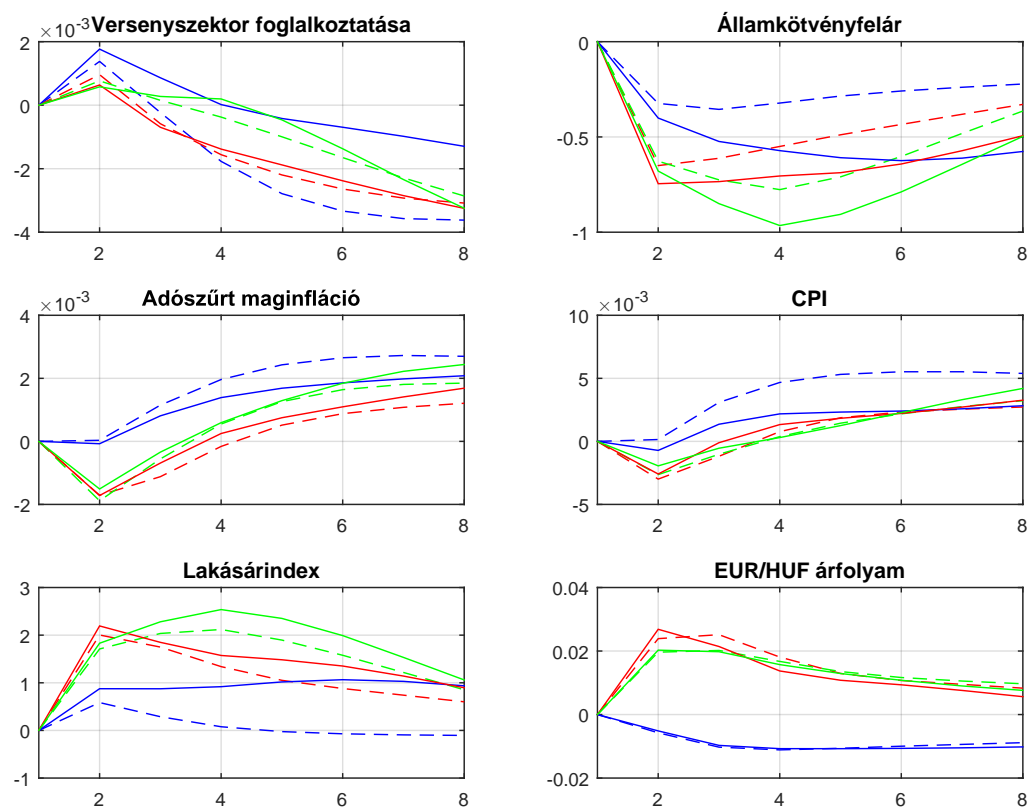

Megjegyzés: a folytonos vonalak jelölik a két pénzügyi faktorral, a szaggatott vonalak az egy pénzügyi faktorral kapott eredményeket (kék=három makrofaktor, piros=négy makrofaktor, zöld=öt makrofaktor). 
5.19. ábra: A hitelállományok- és kamatok impulzusválaszai egy hitelezési képességi sokk esetén 2013 IV. negyedévében (robusztusság vizsgálat)
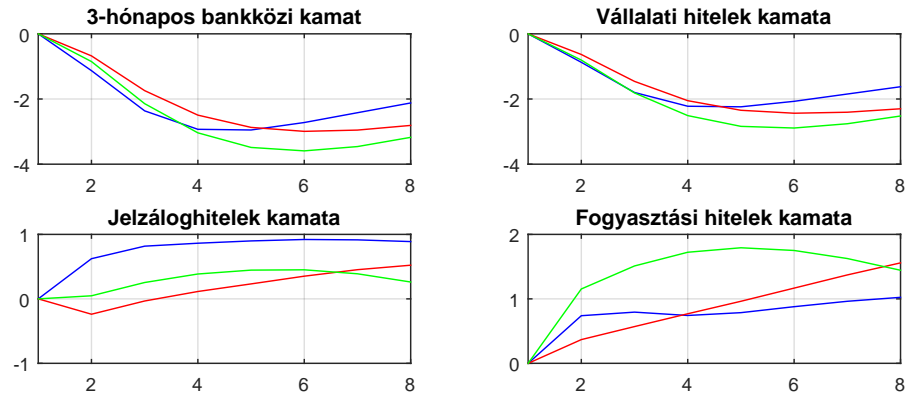

Fogyasztási hitelek kamata
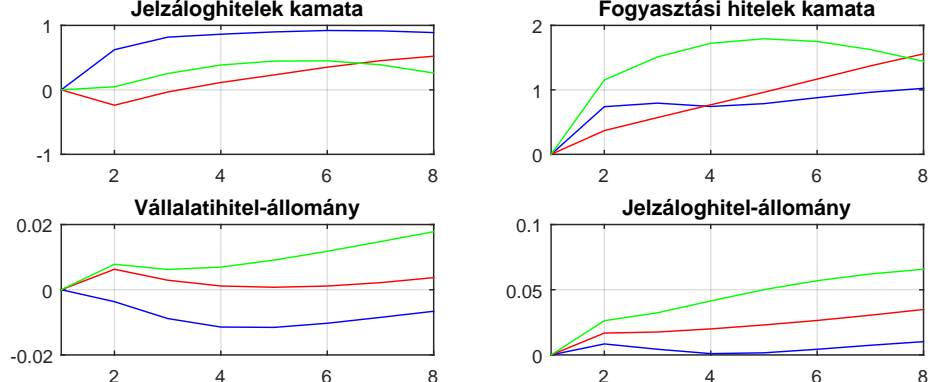

Jelzáloghitel-állomány
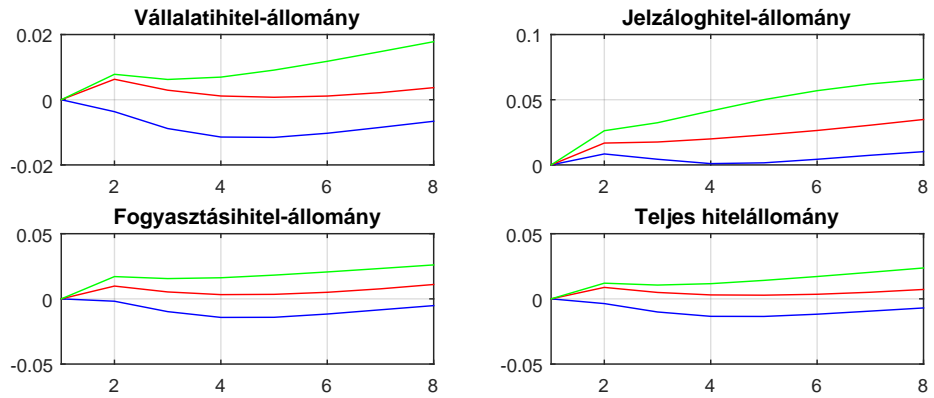

Megjegyzés: a folytonos vonalak jelölik a két pénzügyi faktorral kapott eredményeket (kék=három makrofaktor, piros=négy makrofaktor, zöld=öt makrofaktor). 
5.20. ábra: A fôbb GDP-tételek és az ipari termelés impulzusválaszai egy hitelezési képességi sokk esetén 2013 IV. negyedévében (robusztusság vizsgálat)
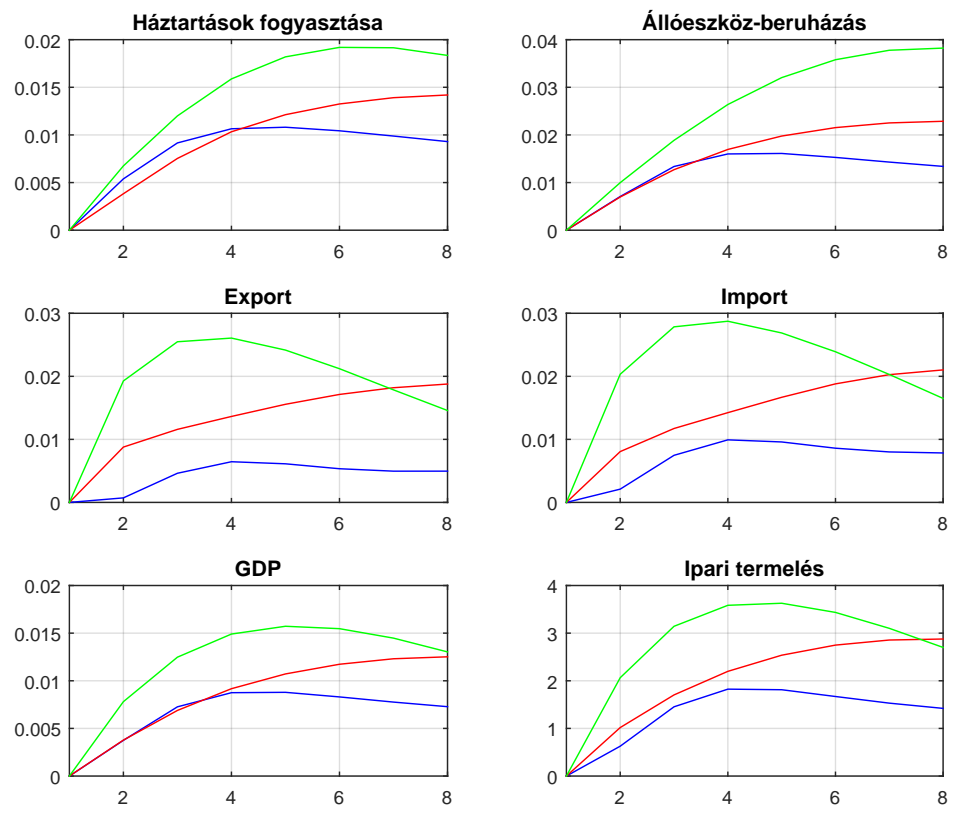

Megjegyzés: a folytonos vonalak jelölik a két pénzügyi faktorral kapott eredményeket (kék=három makrofaktor, piros=négy makrofaktor, zöld=öt makrofaktor). 
5.21. ábra: Foglalkoztatás, államkötvényfelár és árak impulzusválaszai egy hitelezési képességi sokk esetén 2013 IV. negyedévében (robusztusság vizsgálat)
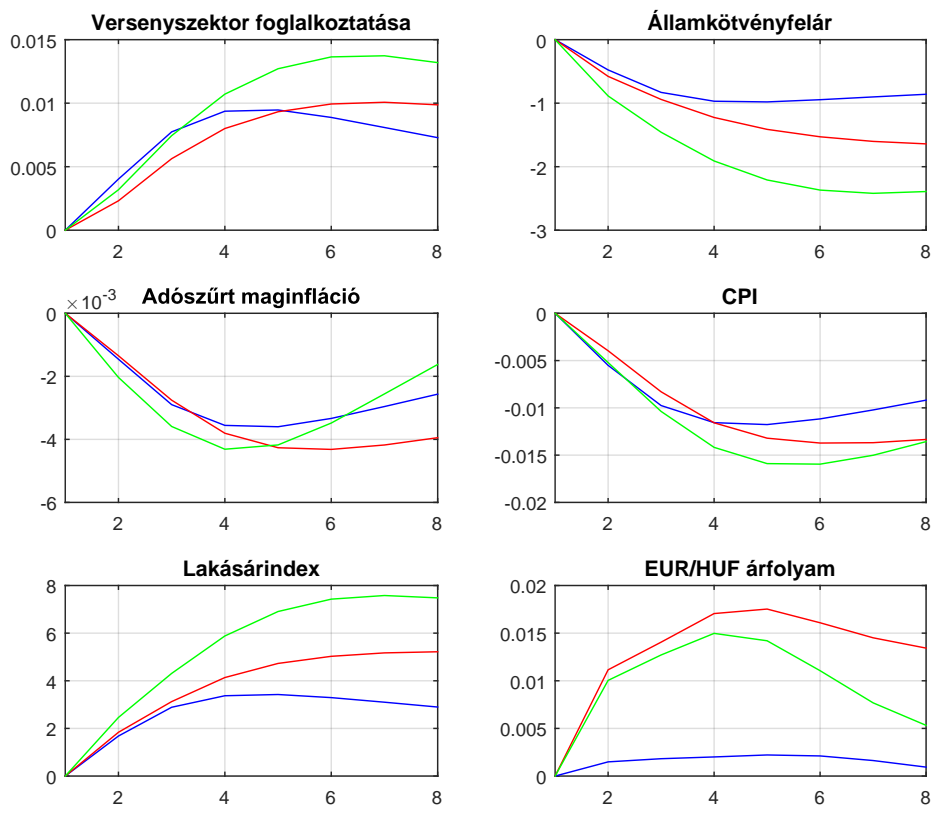

Megjegyzés: a folytonos vonalak jelölik a két pénzügyi faktorral kapott eredményeket (kék=három makrofaktor, piros=négy makrofaktor, zöld=öt makrofaktor). 
B Függelék: a nemteljesítési valószínûség és az optimális

jövedelemarányos

törlesztőrészlet-szabály

modellezésével kapcsolatos kiegészítô információk 
5.3. táblázat: A becslés során kipróbált folytonos változók leíró statisztikái: átlagok

\begin{tabular}{|c|c|c|c|}
\hline & $\begin{array}{l}\text { Teljesítô } \\
\text { háztartások }\end{array}$ & $\begin{array}{l}\text { Nemteljesítő } \\
\text { háztartások }\end{array}$ & $\begin{array}{l}\text { Összes } \\
\text { háztartás }\end{array}$ \\
\hline Kezdeti törlesztőrészlet (ezer Ft) & 38 & 36 & 38 \\
\hline Jelenlegi törlesztőrészlet (ezer Ft) & 52 & 69 & 54 \\
\hline Törlesztőrészlet változása (\%) & 47 & 100 & 54 \\
\hline $\begin{array}{l}\text { Egy keresôre jutó törlesztôrészlet } \\
\text { (ezer Ft) }\end{array}$ & 31 & 47 & 33 \\
\hline $\begin{array}{l}\text { Jövedelemarányos törlesztôrészlet } \\
\text { (PTI - \%) }\end{array}$ & 24 & 55 & 28 \\
\hline $\begin{array}{l}\text { Egyéb hitelekből származó jöve- } \\
\text { delemarányos törlesztőrészlet }(\%)\end{array}$ & 7 & 31 & 10 \\
\hline $\begin{array}{l}\text { Felvett hitelösszeg a fedezet ará- } \\
\text { nában (LTV - \%) }\end{array}$ & 61 & 105 & 67 \\
\hline Felvett hitelösszeg (millió Ft) & 4,6 & 5,2 & 4,7 \\
\hline Háztartás jövedelme (ezer Ft) & 241 & 177 & 233 \\
\hline $\begin{array}{l}\text { Háztartás egy fôre jutó jövedelme } \\
\text { (ezer Ft) }\end{array}$ & 77 & 51 & 74 \\
\hline $\begin{array}{l}\text { Törlesztôrészleten felüli kiadások } \\
\text { (ezer Ft) }\end{array}$ & 193 & 123 & 185 \\
\hline $\begin{array}{l}\text { Keresettel rendelkezók a háztar- } \\
\text { tás létszámának arányában (\%) }\end{array}$ & 53 & 40 & 51 \\
\hline $\begin{array}{l}\text { Munkapiacon aktív, keresettel } \\
\text { rendelkezók a háztartás létszámá- } \\
\text { nak arányában (\%) }\end{array}$ & 62 & 50 & 61 \\
\hline
\end{tabular}


5.4. táblázat: A becslés során kipróbált folytonos változók leíró statisztikái: átlag, medián, szórás

\begin{tabular}{|l|l|l|l|}
\hline & Átlag & Medián & Szórás \\
\hline Kezdeti törlesztőrészlet (ezer Ft) & 38 & 34 & 21 \\
\hline Jelenlegi törlesztőrészlet (ezer Ft) & 54 & 47 & 34 \\
\hline Törlesztôrészlet változása (\%) & 54 & 35 & 79 \\
\hline Egy keresóre jutó törlesztőrészlet (ezer Ft) & 33 & 25 & 26 \\
\hline Jövedelemarányos törlesztórészlet (PTI - \%) & 28 & 23 & 20 \\
\hline $\begin{array}{l}\text { Egyéb hitelekból származó jövedelemarányos } \\
\text { törlesztőrészlet (\%) }\end{array}$ & 10 & 0 & 26 \\
\hline $\begin{array}{l}\text { Felvett hitelösszeg a fedezet aránában (LTV } \\
\text { - \%) }\end{array}$ & 67 & 44 & 147 \\
\hline Felvett hitelösszeg (millió Ft) & 4,7 & 4,0 & 3,3 \\
\hline Háztartás jövedelme (ezer Ft) & 233 & 200 & 110 \\
\hline Háztartás egy fóre jutó jövedelme (ezer Ft) & 74 & 67 & 41 \\
\hline Törlesztőrészleten felüli kiadások (ezer Ft) & 185 & 150 & 181 \\
\hline $\begin{array}{l}\text { Keresettel rendelkezók a háztartás létszámá- } \\
\text { nak arányában (\%) }\end{array}$ & 51 & 50 & 28 \\
\hline $\begin{array}{l}\text { Munkapiacon aktív, keresettel rendelkezók a } \\
\text { háztartás létszámának arányában (\%) }\end{array}$ & 61 & 50 & 26 \\
\hline
\end{tabular}


5.5. táblázat: A becslés során kipróbált dummy-változók

\begin{tabular}{|l|l|l|}
\hline & Igen & Nem \\
\hline Állami kamattámogatás & 17 & 83 \\
\hline Belépett az árfolyamgátba & 18 & 82 \\
\hline Átstrukturált & 23 & 77 \\
\hline 2004-2006 között kibocsátott & 32 & 68 \\
\hline 2007-2008 között kibocsátott & 32 & 68 \\
\hline Szabadfelhasználású jelzáloghitel & 32 & 68 \\
\hline Devizában denominált & 61 & 39 \\
\hline A hitel LTV-je magasabb, mint 100\% & 18 & 82 \\
\hline Közvetítőn keresztüli hitel & 28 & 72 \\
\hline Van a háztartásnak fedezetlen hitele is & 30 & 70 \\
\hline $\begin{array}{l}\text { A háztartás legmagasabb iskolai végzettsége: szakiskola, szak- } \\
\text { középiskola }\end{array}$ & 23 & 77 \\
\hline $\begin{array}{l}\text { A háztartás legmagasabb iskolai végzettsége: gimnázium, } \\
\text { technikum }\end{array}$ & 22 & 78 \\
\hline A háztartás legmagasabb iskolai végzettsége: legalább főiskola & 36 & 64 \\
\hline Háztartás lakhelye: község & 13 & 87 \\
\hline Háztartás lakhelye: város & 44 & 56 \\
\hline Háztartás lakhelye: megyeszékhely, megyei jogú város & 25 & 75 \\
\hline Van a háztartásnak megtakarítása & 10 & 90 \\
\hline
\end{tabular}

Megjegyzés: a táblázatban feltüntetett értékek százalékok 
5.6. táblázat: A kipróbált folytonos változók közötti korreláció

\begin{tabular}{|l|l|l|l|l|l|l|l|l|l|l|l|l|l|}
\hline & 1 & 2 & 3 & 4 & 5 & 6 & 7 & 8 & 9 & 10 & 11 & 12 & 13 \\
\hline 1 & 1,0 & & & & & & & & & & & & \\
\hline 2 & 0,7 & 1,0 & & & & & & & & & & & \\
\hline 3 & $-0,2$ & 0,3 & 1,0 & & & & & & & & & & \\
\hline 4 & 0,5 & 0,8 & 0,3 & 1,0 & & & & & & & & & \\
\hline 5 & 0,4 & 0,6 & 0,3 & $\mathbf{0 , 7}$ & 1,0 & & & & & & & & \\
\hline 6 & & & & & $\mathbf{0 , 1}$ & 1,0 & & & & & & & \\
\hline 7 & 0,1 & 0,2 & & 0,2 & 0,2 & & 1,0 & & & & & & \\
\hline 8 & 0,7 & 0,6 & & 0,5 & 0,4 & & 0,2 & 1,0 & & & & & \\
\hline 9 & 0,3 & 0,2 & $-0,1$ & & $-0,3$ & & & 0,2 & 1,00 & & & & \\
\hline 10 & 0,2 & 0,1 & & & $-0,1$ & $-0,1$ & & 0,1 & 0,6 & 1,00 & & & \\
\hline 11 & & & & $\mathbf{- 0 , 2}$ & $\mathbf{- 0 , 5}$ & & & & 0,4 & 0,2 & 1,0 & & \\
\hline 12 & & & & $\mathbf{- 0 , 1}$ & & & & & & 0,5 & & 1,0 & \\
\hline 13 & 0,1 & 0,1 & & & & & & & 0,1 & 0,4 & 0,6 & & 1,0 \\
\hline
\end{tabular}

Megjegyzés: a táblázatban a sorszámok a következô változókat jelölik: 1 - Kezdeti törlesztôrészlet (ezer Ft), 2 - Jelenlegi törlesztórészlet (ezer Ft), 3 - Törlesztôrészlet változása (\%), 4 - Egy keresőre jutó törlesztốrészlet (ezer Ft), 5 - Jövedelemarányos törlesztórészlet (PTI - \%), 6 Egyéb hitelekból származó jövedelemarányos törlesztôrészlet (\%), 7 - Felvett hitelösszeg a fedezet aránában (LTV - \%), 8 - Felvett hitelösszeg (millió Ft), 9 - Háztartás jövedelme (ezer Ft), 10 Háztartás egy fớre jutó jövedelme (ezer Ft), 11 - Törlesztôrészleten felüli kiadások (ezer Ft), 12 Keresettel rendelkezók a háztartás létszámának arányában (\%), 13 - Munkapiacon aktív, keresettel rendelkezốk a háztartás létszámának arányában (\%). Vastaggal szedve a végsố modellben is szereplô változókat jelöltük. Ahol a korreláció abszolút értékben 0,1-nél kisebb volt, a pontos értéket elhagytuk. 
5.7. táblázat: A logit-becslés eredménye

\begin{tabular}{|l|c|c|}
\hline Változó & Együttható & Sztenderd hiba \\
\hline Konstans & $-4,02^{* * *}$ & 0,77 \\
\hline $\begin{array}{l}\text { Keresettel rendelkezók a háztartás lét- } \\
\text { számának arányában }\end{array}$ & $-6,80^{* * *}$ & 1,34 \\
\hline $\begin{array}{l}\text { Jövedelemarányos törlesztórészlet } \\
\text { (PTI) }\end{array}$ & $15,82^{* * *}$ & 2,23 \\
\hline Devizában denominált & $1,38^{* *}$ & 0,58 \\
\hline $\begin{array}{l}\text { Egyéb hitelekból származó jövedelem- } \\
\text { arányos törlesztôrészlet }\end{array}$ & $5,06^{* * *}$ & 1,05 \\
\hline $\begin{array}{l}\text { Egy keresóre jutó törlesztőrészlet } \\
\text { hline Törlesztôrészleten felüli kiadások }\end{array}$ & $-0,00^{* * *}$ & $0,00^{* * *}$ \\
\hline Közvetítôn keresztüli hitel & $1,06^{* *}$ & 0,00 \\
\hline
\end{tabular}

A táblázatban a csillagok szignifikanciaszinteket mutatnak: egy csillag a 10\%-on, két csillag az 5\%-on és három csillag az 1\%-on szignifikáns változókat jelöli.

5.8. táblázat: A modell illeszkedése

\begin{tabular}{|l|c|}
\hline Mutatók & Értékek \\
\hline Helyesen besorolt megfigyelések aránya & $93,6 \%$ \\
\hline Hosmer-Lemeshow-tesztstatisztika & 3,5 \\
\hline A teszthez tartozó p-érték & 0,898 \\
\hline
\end{tabular}


5.9. táblázat: A PTI változó kihagyásával kapott átlagos parciális hatások

\begin{tabular}{|l|c|}
\hline Változó & Átlagos parciális hatás \\
\hline Konstans & $-19,61^{* *}$ \\
\hline $\begin{array}{l}\text { Keresettel rendelkezók a háztartás lét- } \\
\text { számának arányában }\end{array}$ & $-4,38^{* * *}$ \\
\hline Devizában denominált & $10,1^{* * *}$ \\
\hline $\begin{array}{l}\text { Egyéb hitelekból származó jövedelem- } \\
\text { arányos törlesztôrészlet }\end{array}$ & $0,27^{* * *}$ \\
\hline Egy keresőre jutó törlesztórészlet & $0,816^{* *}$ \\
\hline Közvetítón keresztüli hitel & $7,00^{* * *}$ \\
\hline
\end{tabular}

A táblázatban a csillagok szignifikanciaszinteket mutatnak: egy csillag a 10\%-on, két csillag az 5\%-on és három csillag az 1\%-on szignifikáns változókat jelöli. 
A magyar bankrendszer makroprudenciális szempontból 


\section{Függelék: a banki hatékonyság és verseny mérésével kapcsolatos kiegészítő információk}

5.10. táblázat: A hatékonysági becslésekhez felhasznált változók és számításuk módja

\begin{tabular}{|l|l|l|}
\hline Változó & Számítás & Megjegyzés \\
\hline Összes költség & $\begin{array}{l}\text { Kamatkiadás }+ \text { Szemé- } \\
\text { lyi jellegú ráfordítás }+ \\
\text { Anyagjellegú ráfordítás } \\
+ \text { Amortizáció }\end{array}$ & - \\
\hline
\end{tabular}




\begin{tabular}{|c|c|c|}
\hline „Core" jövedelem & $\begin{array}{l}\text { Nettó kamateredmény+ } \\
\text { Díj- és jutalékeredmény } \\
\text { - Múködési költségek }\end{array}$ & $\begin{array}{l}\text { A díj- és jutalékeredmé- } \\
\text { nyekból a tranzakciós il- } \\
\text { leték becsült bevételnöve- } \\
\text { ló hatása kiszúrésre került. } \\
\text { A becsült hatás kiszámítá- } \\
\text { sa során feltételeztük, hogy } \\
\text { a fizetendó tranzakciós ille- } \\
\text { ték és a pénzforgalmi be- } \\
\text { vételek aránya bankonként } \\
\text { fix. Az arány nagysá- } \\
\text { gát 2016-os tény adatokból } \\
\text { számoltuk. }\end{array}$ \\
\hline $\begin{array}{l}\text { Kamatkiadások a ka- } \\
\text { matozó források ará- } \\
\text { nyában }\end{array}$ & $\begin{array}{l}\text { Kamatkiadás / átlagos } \\
\text { kamatozó források }\end{array}$ & - \\
\hline $\begin{array}{l}\text { Múködési költségek az } \\
\text { összes eszköz arányá- } \\
\text { ban }\end{array}$ & $\begin{array}{l}\text { (Személyi jellegú ráfor- } \\
\text { dítás + Anyag jellegú } \\
\text { ráfordítás + Amortizá- } \\
\text { ció) / Átlagos összes } \\
\text { eszköz }\end{array}$ & - \\
\hline $\begin{array}{l}\text { Hitelezési veszteségek } \\
\text { a háztartási portfólión }\end{array}$ & $\begin{array}{l}\text { (Nettó értékvesztés el- } \\
\text { számolás + Követelé- } \\
\text { sek leírása + Követe- } \\
\text { lések eladásán elszenve- } \\
\text { dett veszteség) /Átlagos } \\
\text { háztartási hitelállomány }\end{array}$ & $\begin{array}{l}\text { A kedvezményes árfolya- } \\
\text { mon történó végtörlesztés } \\
\text { hatását nem vettük figye- } \\
\text { lembe a mutató számítá- } \\
\text { sa során. A 2011-es ered- } \\
\text { ményrontó hatás számítá- } \\
\text { sakor így a } 2010 \text { Q3-2011 } \\
\text { Q2-es idôszak értékeit vet- } \\
\text { tük figyelembe, míg a } 2012- \\
\text { es értéknél a } 2011 \text { Q1 + } \\
2012 \text { Q2-Q4-es időszakot. }\end{array}$ \\
\hline
\end{tabular}




\begin{tabular}{|c|c|c|}
\hline $\begin{array}{l}\text { Hitelezési veszteségek } \\
\text { a vállalati portfólión }\end{array}$ & $\begin{array}{l}\text { (Nettó értékvesztés el- } \\
\text { számolás }+ \text { Követelé- } \\
\text { sek leírása }+ \text { Követe- } \\
\text { lések eladásán elszenve- } \\
\text { dett veszteség) / Átlagos } \\
\text { vállalati hitelállomány }\end{array}$ & - \\
\hline $\begin{array}{l}\text { Háztartási hitelállo- } \\
\text { mány }\end{array}$ & $\begin{array}{l}\text { Lakáscélú hitelek + } \\
\text { Fogyasztási hitelek + } \\
\text { Folyószámla hitelek + } \\
\text { Önálló vállalkozók hi- } \\
\text { telei }\end{array}$ & - \\
\hline $\begin{array}{l}\text { Vállalati hitelállo- } \\
\text { mány }\end{array}$ & $\begin{array}{l}\text { Nem pénzügyi vál- } \\
\text { lalatok felé fennálló } \\
\text { hitelállomány (KKV } \\
\text { és nagyvállalati hite- } \\
\text { lek is) }\end{array}$ & - \\
\hline $\begin{array}{l}\text { Egyéb kamatozó esz- } \\
\text { közök }\end{array}$ & $\begin{array}{l}\text { A magánszektornak } \\
\text { nyújtott hitelen kí- } \\
\text { vüli kamatozó eszköz } \\
\text { (jellemzóen kama- } \\
\text { tozó értékpapírok, } \\
\text { jegybanki betétek, ön- } \\
\text { kormányzati hitelek) }\end{array}$ & - \\
\hline $\begin{array}{l}\text { Likvid eszközök ará- } \\
\text { nya }\end{array}$ & $\begin{array}{l}\text { (Készpénz + jegyban- } \\
\text { ki instrumentumok + } \\
\text { államkötvények ) / } \\
\text { összes eszköz }\end{array}$ & - \\
\hline
\end{tabular}




\begin{tabular}{|l|l|l|}
\hline Tókepuffer nagysága & $\begin{array}{l}\text { II. pillér szerint számí- } \\
\text { tott szabad tőkepuffer } \\
/ \text { teljes kockázati ki- } \\
\text { tettségérték }\end{array}$ & $\begin{array}{l}\text { Bankcsoportok esetén kon- } \\
\text { szolidált számok alapján. }\end{array}$ \\
\hline Fiókok száma & $\begin{array}{l}\text { A bank Magyarorszá- } \\
\text { gon található hálózati } \\
\text { egységeinek száma. }\end{array}$ & - \\
\hline
\end{tabular}


5.11. táblázat: A Lerner-indexek számítása során felhasznált árjellegú változók

\begin{tabular}{|c|c|c|}
\hline Változó & Számítás & Megjegyzés \\
\hline $\begin{array}{l}\text { A háztartási hitele- } \\
\text { ken elért kamatbe- } \\
\text { vétel (eredményki- } \\
\text { mutatás) }\end{array}$ & $\begin{array}{l}\text { (Háztartásoktól } \\
\text { befolyt éves kamat- } \\
\text { bevétel+lakáscélú } \\
\text { hitelek állami ka- } \\
\text { mattámogatása) } \\
\text { átlagos háztartási } \\
\text { hitelállomány }\end{array}$ & $\begin{array}{l}\text { A kamatbevételek közé } \\
\text { az állami kamattámoga- } \\
\text { tás (eszköz- és forrásol- } \\
\text { dali) összegét is belevet- } \\
\text { tük, mivel a teljes árnak } \\
\text { ez is részét képezi. }\end{array}$ \\
\hline $\begin{array}{l}\text { A háztartási hite- } \\
\text { leken elért kamat- } \\
\text { bevétel (kamatsta- } \\
\text { tisztika) }\end{array}$ & $\begin{array}{l}\text { Az egyes háztartási hi- } \\
\text { teltípusok év végi ál- } \\
\text { lományával súlyozott } \\
\text { átlagos kamatláb nö- } \\
\text { velve az egyéb díjak } \\
\text { becsült hatásával }\end{array}$ & $\begin{array}{l}\text { Az egyéb díjakat ban- } \\
\text { konként az új szerződé- } \\
\text { sek THM-kamatláb kü- } \\
\text { lönbözetének mindenko- } \\
\text { ri historikus átlagával } \\
\text { közelítettük. A bankok } \\
\text { által jelentett kamatlá- } \\
\text { bak már tartalmazzák } \\
\text { az állami támogatást, } \\
\text { így ezzel nem volt szük- } \\
\text { séges korrigálni. }\end{array}$ \\
\hline $\begin{array}{l}\text { A vállalati hitele- } \\
\text { ken elért kamatbe- } \\
\text { vétel (eredményki- } \\
\text { mutatás) }\end{array}$ & $\begin{array}{l}\text { Vállalatoktól befolyt } \\
\text { éves kamatbevétel / } \\
\text { átlagos vállalati hitel- } \\
\text { állomány }\end{array}$ & - \\
\hline $\begin{array}{l}\text { A vállalati hitele- } \\
\text { ken elért kamat- } \\
\text { bevétel (kamatsta- } \\
\text { tisztika) }\end{array}$ & $\begin{array}{l}\text { Állománnyal súlyozott } \\
\text { vállalati kamatlábak }\end{array}$ & - \\
\hline
\end{tabular}




\begin{tabular}{|c|c|c|}
\hline $\begin{array}{lr}\text { Az új } & \text { szerződések } \\
\text { teljes } & \text { hitelkölt- } \\
\text { sége } & \text { (lakossági } \\
\text { szegmens) }\end{array}$ & $\begin{array}{l}\text { Az egyes háztartási } \\
\text { hiteltípusok év során } \\
\text { szerződött volumené- } \\
\text { vel súlyozott átlagos } \\
\text { THM }\end{array}$ & - \\
\hline $\begin{array}{l}\text { Az új szerződések } \\
\text { átlagos kamatlába } \\
\text { (vállalati szeg- } \\
\text { mens) }\end{array}$ & $\begin{array}{l}\text { A vállalati hitelszer- } \\
\text { zôdések szerzôdéses } \\
\text { összegével súlyozott } \\
\text { átlagos kamatláb }\end{array}$ & - \\
\hline
\end{tabular}

5.12. táblázat: A költség- és profithatékonysági becslés során felhasznált változók leíró statisztikái (az állományok millió Ft-ban szerepelnek)

\begin{tabular}{|l|l|c|c|c|c|}
\hline & & Átlag & Szórás & Min. & Max. \\
\hline Célváltozók & Összes költség & 104437 & 136700 & 2761 & 814497 \\
\hline & $\begin{array}{l}\text { „Core jövede- } \\
\text { lem" }\end{array}$ & 31188 & 56292 & -3498 & 272949 \\
\hline Inputok & $\begin{array}{l}\text { Kamatozó forrá- } \\
\text { sok }\end{array}$ & 1403477 & 1539629 & 20915 & 7262631 \\
\hline & $\begin{array}{l}\text { Múködési költsé- } \\
\text { gek }\end{array}$ & 37360 & 36975 & 1658 & 171977 \\
& $\begin{array}{l}\text { Értékvesztés } \\
\text { eredményron- } \\
\text { tó hatása } \\
\text { vállalatok }\end{array}$ & 6019 & 12863 & -36484 & 86164 \\
\hline
\end{tabular}




\begin{tabular}{|c|c|c|c|c|c|}
\hline & $\begin{array}{l}\text { Értékvesztés } \\
\text { eredményron- } \\
\text { tó hatása - } \\
\text { háztartások }\end{array}$ & 6212 & 10853 & -18482 & 60467 \\
\hline \multirow[t]{4}{*}{ Inputárak } & $\begin{array}{l}\text { Kamatkiadások } \\
\text { / kamatozó } \\
\text { források }\end{array}$ & 0,045 & 0,023 & 0,003 & 0,100 \\
\hline & $\begin{array}{l}\text { Múködési költ- } \\
\text { ségek/összes } \\
\text { eszköz }\end{array}$ & 0,028 & 0,014 & 0,011 & 0,101 \\
\hline & $\begin{array}{l}\text { Vállalati hitelek } \\
\text { értékveszté- } \\
\text { se/vállalati } \\
\text { hitelállomány }\end{array}$ & 0,010 & 0,020 & 0,118 & 0,131 \\
\hline & $\begin{array}{l}\text { Háztartási hite- } \\
\text { lek értékveszté- } \\
\text { se/háztartási hi- } \\
\text { telállomány }\end{array}$ & 0,014 & 0,017 & 0,035 & 0,082 \\
\hline \multirow[t]{3}{*}{ Outputok } & Vállalati hitelek & 416484 & 339477 & 2 & 1267817 \\
\hline & $\begin{array}{l}\text { Háztartási hite- } \\
\text { lek }\end{array}$ & 365488 & 471344 & 1826 & 2326555 \\
\hline & $\begin{array}{l}\text { Egyéb kamatozó } \\
\text { eszközök }\end{array}$ & 764823 & 1016823 & 2781 & 5365439 \\
\hline \multirow[t]{3}{*}{$\begin{array}{l}\text { Kontroll- } \\
\text { változók }\end{array}$} & $\begin{array}{l}\text { Likvid eszközök } \\
\text { aránya }\end{array}$ & 0,153 & 0,086 & 0,075 & 0,761 \\
\hline & Tókepufferráta & 0,072 & 0,072 & 0,000 & 0,292 \\
\hline & Fiókok száma & 107 & 116 & 4 & 662 \\
\hline
\end{tabular}


5.13. táblázat: Becslési outputok, célváltozó: profit hitelezési veszteségekkel együtt

\begin{tabular}{|l|l|l|l|}
\hline Változónév & Együttható & $\begin{array}{l}\text { Standard } \\
\text { hiba }\end{array}$ & P-érték \\
\hline lnhh & $-0,76$ & 0,28 & 0,01 \\
\hline lnvh & 0,24 & 0,14 & 0,09 \\
\hline lnwpe & 0,75 & 0,71 & 0,29 \\
\hline lnwie & 0,67 & 0,27 & 0,01 \\
\hline lnwpewie & 0,28 & 0,07 & 0,00 \\
\hline lnwpe2 & 0,20 & 0,17 & 0,26 \\
\hline lnwie2 & 0,00 & 0,03 & 0,91 \\
\hline lnhhvh & $-0,01$ & 0,01 & 0,43 \\
\hline lnhh2 & $-0,05$ & 0,02 & 0,02 \\
\hline lnvh2 & 0,01 & 0,01 & 0,49 \\
\hline lnhhwpe & 0,25 & 0,06 & 0,00 \\
\hline lnhhwie & $-0,11$ & 0,05 & 0,04 \\
\hline lnvhwpe & $-0,18$ & 0,04 & 0,00 \\
\hline lnvhwie & $-0,01$ & 0,02 & 0,45 \\
\hline lnllphh & 0,97 & 0,52 & 0,06 \\
\hline lnllpvh & 0,59 & 0,15 & 0,00 \\
\hline lnhhllphh & $-0,10$ & 0,04 & 0,02 \\
\hline lnvhllpvh & $-0,09$ & 0,02 & 0,00 \\
\hline lnotha & $-0,72$ & 0,29 & 0,01 \\
\hline lnotha2 & 0,07 & 0,08 & 0,35 \\
\hline lnothahh & 0,14 & 0,04 & 0,00 \\
\hline & & & \\
\hline
\end{tabular}

\footnotetext{
${ }^{1} \mathrm{~A}$ változónevekben az ln arra utal, hogy a változóink logaritmizálva vannak. hh a háztartási, vh a vállalati hitelállomány rövidítése, otha jelöli az egyéb kamatozó eszközöket. A 2-es szám a négyzetes tagok esetén szerepel, wpe az operatív költségek az összes eszköz arányában, wie a kamatkiadások a kamatozó forrásokhoz viszonyítva. llpvh és llphh az értékvesztések, puffer jelöli a tókepufereket.
} 
Hivatkozások

\begin{tabular}{|l|l|l|l|}
\hline lnothavh & $-0,09$ & 0,03 & 0,00 \\
\hline lnothawpe & 0,01 & 0,09 & 0,89 \\
\hline lnothawie & 0,14 & 0,07 & 0,05 \\
\hline lnuffer & 0,04 & 0,02 & 0,03 \\
\hline konstans & 21,69 & 2,36 & 0,00 \\
\hline
\end{tabular}

5.14. táblázat: Becslési outputok, célváltozó: költségek hitelezési veszteségekkel együtt

\begin{tabular}{|l|c|c|c|}
\hline Változónév & Együttható & Standard hiba & P-érték \\
\hline lnhh & 0,43 & 0,11 & 0,00 \\
\hline lnvh & 0,41 & 0,08 & 0,00 \\
\hline lnwpe & 1,23 & 0,31 & 0,00 \\
\hline lnwie & 0,80 & 0,14 & 0,00 \\
\hline lnwpewie & $-0,14$ & 0,04 & 0,00 \\
\hline lnwpe2 & $-0,16$ & 0,09 & 0,07 \\
\hline lnwie2 & 0,20 & 0,02 & 0,00 \\
\hline lnhhvh & $-0,03$ & 0,01 & 0,00 \\
\hline lnhh2 & 0,09 & 0,02 & 0,00 \\
\hline lnvh2 & 0,04 & 0,00 & 0,00 \\
\hline lnhhwpe & 0,03 & 0,03 & 0,33 \\
\hline lnhhwie & $-0,05$ & 0,03 & 0,05 \\
\hline lnvhwpe & 0,11 & 0,02 & 0,00 \\
\hline lnvhwie & 0,05 & 0,01 & 0,00 \\
\hline lnllphh & $-0,30$ & 0,26 & 0,25 \\
\hline lnllpvh & $-0,72$ & 0,07 & 0,00 \\
\hline
\end{tabular}

\footnotetext{
${ }^{2} \mathrm{Az}$ előző táblázathoz képest két újabb változó van a magyarázóváltozók között, liq jelöli a likvid eszközök arányát, fiok pedig a bankfiókok számát.
} 


\begin{tabular}{|l|c|c|c|}
\hline lnhhllphh & 0,04 & 0,02 & 0,04 \\
\hline lnvhllpvh & 0,12 & 0,01 & 0,00 \\
\hline lnotha & 0,38 & 0,14 & 0,01 \\
\hline lnotha2 & $-0,02$ & 0,04 & 0,65 \\
\hline lnothahh & $-0,08$ & 0,02 & 0,00 \\
\hline lnothavh & 0,03 & 0,01 & 0,02 \\
\hline lnothawpe & $-0,27$ & 0,04 & 0,00 \\
\hline lnothawie & 0,00 & 0,04 & 0,91 \\
\hline lnuffer & $-0,01$ & 0,01 & 0,16 \\
\hline lnliq & $-0,07$ & 0,02 & 0,00 \\
\hline lnfiok & 0,05 & 0,02 & 0,00 \\
\hline konstans & 2,05 & 0,95 & 0,03 \\
\hline
\end{tabular}

5.15. táblázat: Becslési outputok, célváltozó: profit

\begin{tabular}{|l|c|c|c|}
\hline Változónév & Együttható & Standard hiba & P-érték \\
\hline lnhh & $-1,30$ & 0,41 & 0,00 \\
\hline lnvh & 0,27 & 0,31 & 0,39 \\
\hline lnwpe & 2,22 & 1,30 & 0,09 \\
\hline lnwie & 3,22 & 0,62 & 0,00 \\
\hline lnwpewie & 0,40 & 0,15 & 0,01 \\
\hline lnwpe2 & 1,33 & 0,38 & 0,00 \\
\hline lnwie2 & $-0,04$ & 0,07 & 0,58 \\
\hline lnhhvh & $-0,08$ & 0,03 & 0,00 \\
\hline lnhh2 & $-0,15$ & 0,05 & 0,00 \\
\hline $\ln v 2$ & 0,07 & 0,02 & 0,00 \\
\hline
\end{tabular}

\footnotetext{
${ }^{3}$ A rövidítések ugyanazokat a változókat jelölik, mint az előzó két táblázatnál. Forrás: saját számítások.
} 


\begin{tabular}{|l|c|c|c|}
\hline lnhhwpe & 0,74 & 0,12 & 0,00 \\
\hline lnhhwie & $-0,36$ & 0,09 & 0,00 \\
\hline lnvhwpe & $-0,14$ & 0,07 & 0,03 \\
\hline lnvhwie & 0,03 & 0,04 & 0,45 \\
\hline lnotha & $-1,18$ & 0,59 & 0,04 \\
\hline lnotha2 & $-0,27$ & 0,13 & 0,05 \\
\hline lnothahh & 0,45 & 0,08 & 0,00 \\
\hline lnothavh & $-0,04$ & 0,05 & 0,44 \\
\hline lnothawpe & $-0,23$ & 0,15 & 0,11 \\
\hline lnothawie & 0,16 & 0,15 & 0,28 \\
\hline lnuffer & 0,17 & 0,03 & 0,00 \\
\hline konstans & 27,30 & 3,41 & 0,00 \\
\hline
\end{tabular}

5.16. táblázat: Becslési outputok, célváltozó: költségek

\begin{tabular}{|l|c|c|c|}
\hline Változónév & Együttható & Standard hiba & P-érték \\
\hline lnhh & 0,23 & 0,07 & 0,00 \\
\hline lnvh & 0,24 & 0,06 & 0,00 \\
\hline lnwpe & 1,30 & 0,20 & 0,00 \\
\hline lnwie & 0,72 & 0,09 & 0,00 \\
\hline lnwpewie & $-0,16$ & 0,03 & 0,00 \\
\hline lnwpe2 & $-0,22$ & 0,06 & 0,07 \\
\hline lnwie2 & 0,24 & 0,01 & 0,00 \\
\hline lnhhvh & $-0,02$ & 0,01 & 0,01 \\
\hline lnhh2 & 0,09 & 0,01 & 0,00 \\
\hline lnvh2 & 0,03 & 0,00 & 0,00 \\
\hline
\end{tabular}

\footnotetext{
${ }^{4} \mathrm{~A}$ rövidítések ugyanazokat a változókat jelölik, mint az előző két táblázatnál. Forrás: saját számítások.
} 


\begin{tabular}{|l|c|c|c|}
\hline lnhhwpe & $-0,01$ & 0,02 & 0,50 \\
\hline lnhhwie & $-0,05$ & 0,02 & 0,01 \\
\hline lnvhwpe & 0,11 & 0,01 & 0,00 \\
\hline lnvhwie & 0,07 & 0,01 & 0,00 \\
\hline lnotha & 0,32 & 0,09 & 0,00 \\
\hline lnotha2 & 0,01 & 0,03 & 0,69 \\
\hline lnothahh & $-0,09$ & 0,02 & 0,00 \\
\hline lnothavh & 0,03 & 0,01 & 0,00 \\
\hline lnothawpe & $-0,26$ & 0,03 & 0,00 \\
\hline lnothawie & $-0,01$ & 0,03 & 0,65 \\
\hline lnuffer & $-0,01$ & 0,01 & 0,03 \\
\hline lnliq & $-0,09$ & 0,01 & 0,00 \\
\hline lnfiok & 0,05 & 0,01 & 0,00 \\
\hline konstans & 4,71 & 0,53 & 0,00 \\
\hline
\end{tabular}

5.17. táblázat: Becslési stastisztikák, célváltozó: profit hitelezési veszteségekkel együtt

\begin{tabular}{|l|c|c|c|}
\hline Statisztika & Értéke & Standard hiba & P-érték \\
\hline Usigma & 0,19 & 0,02 & 0,00 \\
\hline Vsigma & 0,05 & 0,01 & 0,00 \\
\hline Lambda & 3,47 & & \\
\hline Log-likelihood & 82,59 & & \\
\hline Wald & 1528,62 & & 0,00 \\
\hline
\end{tabular}

Usigma és Vsigma a hibatagok szórásai, lambda a két szórás hányadosa. 
Hivatkozások

5.18. táblázat: Becslési stastisztikák, célváltozó: költségek hitelezési veszteségekkel együtt

\begin{tabular}{|l|c|c|c|}
\hline Statisztika & Értéke & Standard hiba & P-érték \\
\hline Usigma & 0,03 & 0,01 & 0,02 \\
\hline Vsigma & 0,06 & 0,01 & 0,00 \\
\hline Lambda & 0,47 & & \\
\hline Log-likelihood & 252,59 & & \\
\hline Wald & 77873,00 & & 0,00 \\
\hline
\end{tabular}

5.19. táblázat: Becslési stastisztikák, célváltozó: profit

\begin{tabular}{|l|c|c|c|}
\hline Statisztika & Értéke & Standard hiba & P-érték \\
\hline Usigma & 0,45 & 0,04 & 0,00 \\
\hline Vsigma & 0,11 & 0,02 & 0,00 \\
\hline Lambda & 4,02 & & \\
\hline Log-likelihood & $-78,44$ & & \\
\hline Wald & 2741,97 & & 0,00 \\
\hline
\end{tabular}

5.20. táblázat: Becslési stastisztikák, célváltozó: költségek

\begin{tabular}{|l|c|c|c|}
\hline Statisztika & Értéke & Standard hiba & P-érték \\
\hline Usigma & 0,03 & 0,01 & 0,00 \\
\hline Vsigma & 0,04 & 0,00 & 0,00 \\
\hline Lambda & 0,96 & & \\
\hline Log-likelihood & 313,35 & & \\
\hline Wald & 148569,50 & & 0,00 \\
\hline
\end{tabular}

A DEA modellek múködési elvét két egyszerú számpéldán és azok grafikus megjelenítésén keresztül szemléltetjük. Tegyük fel, hogy három bank adatait ismerjük, melyek egy inputból (például humán erőforrás) állítanak elő két outputot (hitel és egyéb kamatozó eszközök). Továbbá tegyük fel, hogy mindhárom bank pontosan 
10 fôt foglalkoztatott, de különböző számú outputot termelt: $A$ bank 15 hitelt és 20 egyéb eszközt, $B$ bank 5 hitelt és 40 egyéb eszközt, míg $C$ bank 2 hitelt és 100 egyéb eszközt.

Egy DEA modell szerint ekkor az $A$ bank hatékony, mert $B$ és $C$ konvex kombinációjából nem tudunk egy olyan mesterséges bankot létrehozni, amely azonos inputszinttel több outputot érne el, mint $A(5.22$ es ábra). Ugyanez igaz a $C$ bankra is. $B$ bank esetén azonban létezik ilyen mesterséges bank, ezt jelöltük az ábrán az $E$ ponttal (a teljes hatékony felületet pedig vastag vonallal). $B$ hatékonytalanságát pedig az origótól és az $E$ ponttól vett távolsága adja meg: $1-O B / O E$ (ahol $O$ jelöli az origót). Az inputok és outputok, valamint a további feltételek számának a növekedésével természetesen a dimenziószám is növekszik, így a grafikus megjelenítés már nem lehetséges, lineáris programozásra van szükség a probléma megoldásához.

5.22. ábra: A DEA modellek szemléltetése: egy input, két output

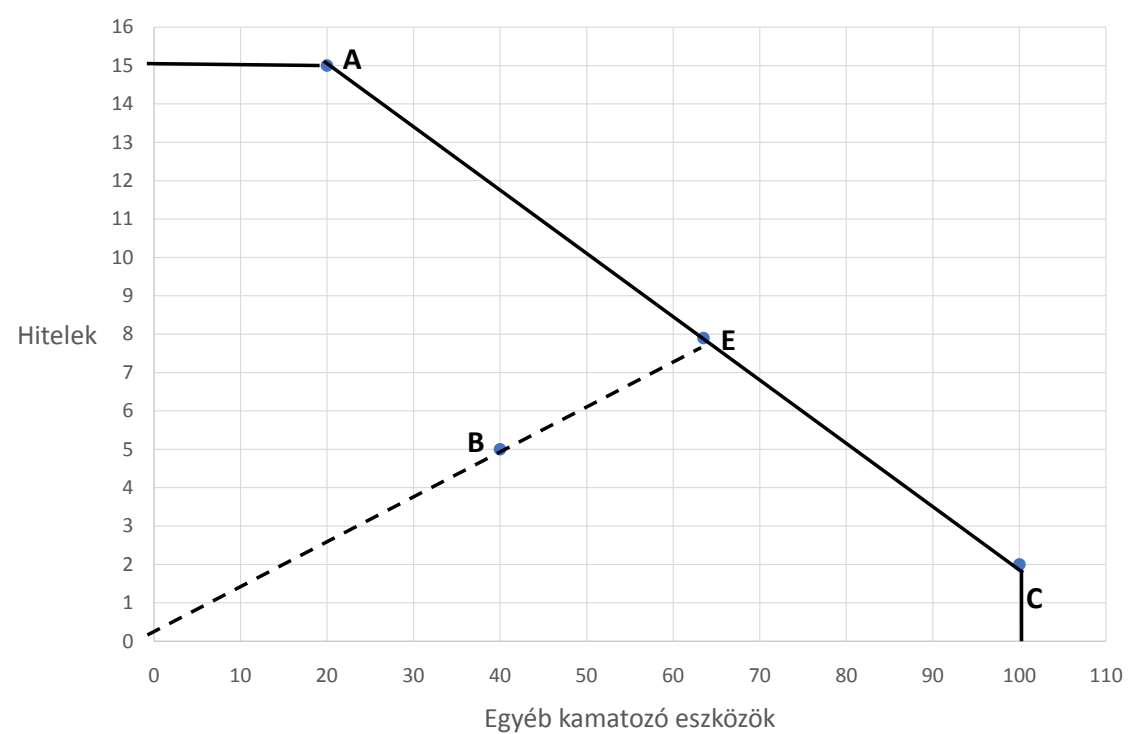

Konstans mérethozadék feltételezése mellett ekkor csak a $B$ bank lesz hatékony, hiszen $B$ alapján $X$ mennyiségú inputból $2 X$ mennyiségú outputot lehetne termel- 
ni, aminél a másik két bank kevesebbet állít elő (a hatékony pontok halmazát az ábrán szaggatott vonallal jeleztük). Változó mérethozadék esetén azonban mindhárom bank hatékony lesz, és a hatékony pontok halmazát a bankokat összekötő szakaszok alkotják $(A B$ és $B C$ ). Ezektôl a szakaszoktól jobbra és lefelé vannak a kevésbé hatékony termelési lehetôségek.

A fent bemutatott példa kapcsán a mérethozadék kérdését nem kellett tárgyalni, mivel mindegyik bank ugyanakkora költséggel érte el az outputokat. Tegyük fel most, hogy továbbra is három bankunk van, ezek azonban egy input (humán erôforrás) felhasználásával egy outputot (hitel) állítanak elő. $A$ bank most 3 fôvel 3 egységnyi hitelt állított elő, $B$ bank 4 fôvel 9 hitelt, $C$ bank pedig 10 fôvel 10 egységnyi hitelt (5.23 as ábra).

5.23. ábra: A DEA modellek szemléltetése: a mérethozadék szerepe

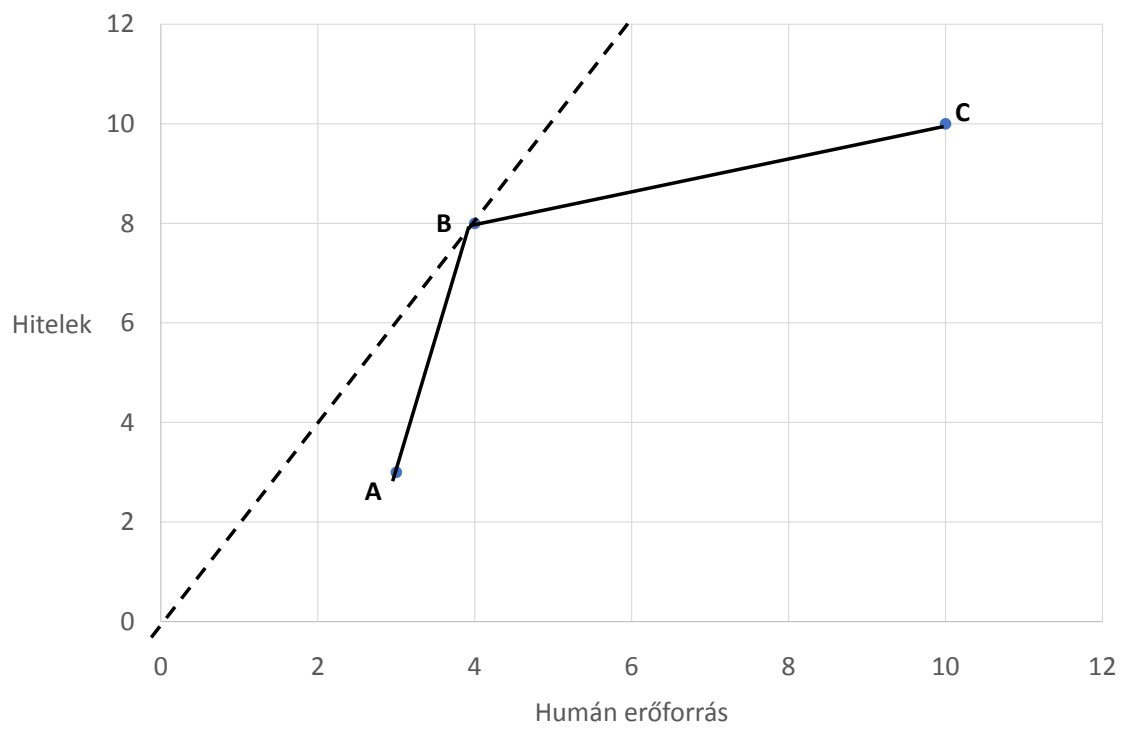


A magyar bankrendszer makroprudenciális szempontból 


\section{Saját publikációk a témában}

\section{Magyar nyelvû referált szakmai folyóiratcikkek}

- Hosszú Zs., Körmendi Gy., Mérő B. (2016), „Egy- és többváltozós szúrôk a hitelrés alakulásának meghatározására", Közgazdasági Szemle, vol. 63, 2016. március, pp. 233-259.

- Hosszú Zs., Mérő B. (2017), „Hitelciklusok és anticiklikus tôkepuffer egy ágensalapú Keynesi modellben”, Közgazdasági Szemle, vol. 64, 2017. május, pp. 457-475.

\section{Magyar nyelvû mủhelytanulmányok, konferenciaelőadások}

- Balás T., Banai Á., Hosszú Zs. (2015), „A nemteljesítési valószínúség és az optimális PTI-szint modellezése egy háztartási kérdôíves felmérés felhasználásával", MNB-tanulmány, 117.

- Banai Á., Hosszú Zs., Körmendi Gy., Mérő B. (2014), „A kamatcsökkentés hatása a banki jövedelmezőségre", MNB-szemle, 2014. július, pp. $18-22$.

- Banai Á., Hosszú Zs., Körmendi Gy., Sóvágó S., Szegedi R. (2013), „Stressztesztek a Magyar Nemzeti Bank gyakorlatában”, MNB-tanulmány, 109.

- Dancsik B., Hosszú Zs (2017), „Banki hatékonyság és piaci erô mérése a háztartási és a vállalati hitelpiacon a hitelezési kockázatok figyelembevétele mellett", MNB-tanulmány, 133. 
- Hosszú Zs. (2011), „A lakosság fogyasztási viselkedése és annak jövedelem szerinti heterogenitása a válság előtt mikrostatisztikák alapján", MNB-szemle, 2011. október, pp. 28-35.

- Hosszú Zs., Körmendi Gy., Tamási B., Világi B. (2013), „A hitelkínálat hatása a magyar gazdaságra", MNB-szemle különszám, 2013. október, pp. 83-92.

- Hosszú Zs. (2013), „A vállalati hitelpiac ágensalapú modellezése”, Közgazdasági Doktori Iskola IX. éves konferenciája, 2013. november, Budapest

- Hosszú Zs., Körmendi Gy., Mérő B. (2016), „Egy- és többváltozós szűrôk a hitelrés alakulásának meghatározására", MNB-tanulmány, 118.

- Hosszú Zs (2016), „The impact of credit supply shocks and a new FCI based on a FAVAR approach", Magyar Közgadaságtudományi Egyesület 2016. évi doktorandusz múhelye (magyar nyelvú elóadás), 2016. június, Pécs

- Hosszú Zs. (2016), „The impact of credit supply shocks and a new FCI based on a FAVAR approach", Altalános és Kvantitatív Közgazdaságtani Doktori Iskola XII. éves konferenciája (magyar nyelvú elóadás), 2016. november, Budapest

\section{Angol nyelvü referált szakmai folyóiratcikkek}

- Balás, T., Banai Á., Hosszú Zs. (2015), „Modelling Probability of Default and Optimal PTI Level by Using a Household Survey", Acta Oeconomica, vol. 65, no. 1, pp. $183-210$.

- Hosszú Zs. (2018), „The impact of credit supply shocks and a new Financial Conditions Index based on a FAVAR approach", Economic Systems, vol. 42., 32-44. pp.

- Dancsik B., Hosszú Zs. (2018), „Measuring bank efficiency and market power in the household and corporate credit markets considering credit risks" Acta Oeconomica, publikálásra elfogadott kézirat, várható megjelenés: 2018. június 


\section{Angol nyelvü mühelytanulmányok, konferenciaelôadások}

- Banai Á., Hosszú Zs., Körmendi Gy., Mérô B. (2014), „Impact of base rate cuts on banks profitability", MNB Bulletin, 2014. július, 18-22. pp.

- Banai Á., Hosszú Zs., Körmendi Gy., Sóvágó S., Szegedi R. (2013), „Stress testing at the Magyar Nemzeti Bank”, MNB Occasional Paper, 109.

- Hosszú Zs. (2011), „Pre-crisis household consumption behaviour and its heterogeneity according to income on the basis of micro statistics", $M N B$ Bulletin, 2011. október, 28-35. pp.

- Hosszú Zs., Körmendi Gy., Tamási B., Világi B. (2013), „Impact of the credit supply on the Hungarian economy", MNB Bulletin Special Issue, 2013. október, 83-92. pp.

- Hosszú Zs., Körmendi Gy., Mérő B. (2015), „Univariate and multivariate HP-filters to measure the credit gap", MNB Occasional Paper, no. 118.

- Hosszú Zs. (2016), „The impact of credit supply shocks and a new FCI based on a FAVAR approach", MNB Working Paper,2016/1.

- Hosszú Zs. (2016), „The impact of credit supply shocks and a new FCI based on a FAVAR approach", Challenges for Financial Stability in Europe Conference, 2016. október, Prága

- Hosszú Zs., Mérő B. (2017), „An agent based Keynesian model with credit cycles and countercyclical capital buffer", MNB Working Paper, $2017 / 5$. 